\title{
MAI RANGIRIRI KI PŌKAEWHENUA: THE CONFISCATION OF PŌKAEWHENUA IN THE NATIONAL INTEREST - 1961-1969
}

\author{
BY \\ DIONE LEE MARAMA PAYNE \\ A thesis submitted to the Victoria University of Wellington in fulfilment of the \\ requirements for the degree of Doctor of Philosophy
}

Victoria University of Wellington 
Photo 1: Te Ao Mārama Te Puru (nee Tamehana) - original owner in Pōkaewhenua.

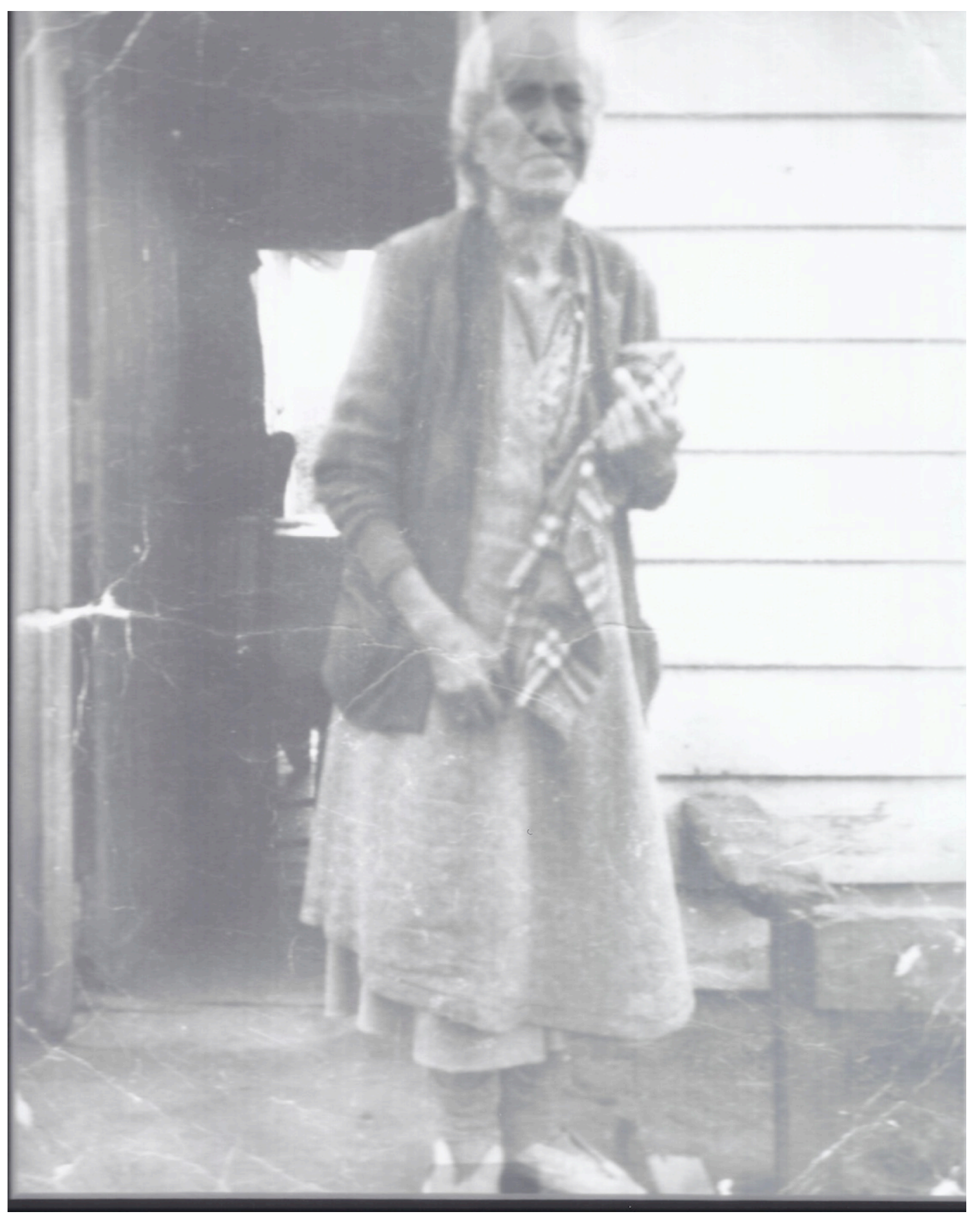




\begin{abstract}
The title of this thesis, Mai Rangiriri ki Pōkaewhenua, refers to the battle of Rangiriri as the point of reference that marks the first confiscation of Waikato land. It was at Rangiriri that Waikato Māori took up arms to defend their land against the invading army and in doing so, by Crown law, forfeited their customary ownership over their land through confiscation. It would be one hundred years later that another confiscation occured at Pōkaewhenua in the 1960s.
\end{abstract}

The confiscation of Māori land is commonly discussed in New Zealand history literature as a practice of the nineteenth-century. However in this thesis I argue the practice of confiscation has endured into the 1960s through facilitated alienations of allegedly unproductive Māori land through lease and sale.

This thesis examines the case study of Lot 512 in the Parish of Whangamarino to show how government agencies utilised some common practices of confiscation such as through legislation, economic expansion, settlement, conflict of interests, tenurial revolution and the concept of waste land to confiscate Pōkaewhenua through facilitated alienation in the national interest.

Although the practice of alienation was widespread, the sale and lease of Māori land due to an alleged lack of productivity under Part XXV of the Māori Affairs Act 1953 was seldom investigated as part of Treaty settlements. For hapū and whānau, particularly in the Waikato, the re-examination of land alienation may change their land history and the manner in which future Treaty claims are investigated.

Contemporarily, the drive for greater productivity of Māori land, as seen in the 2013 Review of the Te Ture Whenua Māori Act, focuses again on making all Māori land productive in the national interest, with little consideration of the impact on it's Māori owners. The criteria and rationale for this push for productivity is strongly reminiscent of the practice in the 1960s and 1860s, and suggests any national interest alienations that occur as a result of the 2013 review, may also be confiscation. 
One significant implication of this thesis for the field of Māori Studies is that the investigation of Lot 512 provides another perspective on confiscation. This thesis expands the definition of confiscation to allow for alienation by sale and lease in the national interest and departs from the limitation of the nineteenth-century. This research also contributes to Māori Studies through the analysis of Part XXV of the Māori Affairs Act 1953. As a wider implication for Māori land, it challenges researchers to look more closely at Māori land sales in the 1950-1960s, the manner in which those sales and leases were undertaken and questions national interest arguments for alienating further Māori land.

This thesis is centred around a Māori world view and approach to research and is tied specifically to Pōkaewhenua - Lot 512 in the Parish of Whangamarino, but has implications for thinking about the way Indigenous rights are made subservient to colonial interests. 


\section{Acknowledgments}

I would like to thank my primary supervisor, Dr Maria Bargh, for her immense support, critical feedback, guidance and dedication to my study. I have appreciated all the assistance over these past three years. I would also like to thank Peter Adds, my secondary supervisor, Te Kawa a Maui and my $\mathrm{PhD}$ colleagues that provided support and feedback during my research.

I am also especially grateful for my wider whānau, particularly my kaumātua of Ngāti Hinemihi, Takotowai Webb, Gail Bennett, Edwin Ashford, the Kapinga whānau, the Te Akau whānau, Ngāti Naho, through Brad Totorewa's support and the use of his Tongikura framework, my Ngāti Hine and Ngāti Mahuta whānau including Judith-Anne Wanakore, Horiana Harris, Alison Ahu, Theresa Ahu, my cousins (in particular Maree Waru and Kiriana Hakopa), my Ngāti Turumakina whānau, Rueben Grace and my Ngāti Karauia kuia, Rose Albert.

I would like to make a special mention of my grandmother, Ngawini Toka Puru, who played a significant role in linking my study to Te Ao Mārama in Pōkaewhenua. I am deeply indebted to her for her support, guidance, enthusiasm and willingness to share all she knew throughout my study.

I would also like to acknowledge the financial assistance I received during my study from Waikato Raupatu Lands Trust for the Tainui PhD Scholarship, Victoria University for the Ahumairangi $\mathrm{PhD}$ Scholarship and Office of the PVC Māori/Toihuarewa Scholarship, Morikau Incorporation for the Dr Rangi Metekingi Post-graduate Scholarship and Atihau Incorporation for the Robyn Murphy-Peehi Post-graduate Scholarship. I am also grateful to the Whakairoiro Ahu Whenua Trust, Hauraki Māori Trust Board, Maniapoto Māori Trust Board, Sir James Fletcher Incorporation, Ngāti Tuwharetoa Māori Trust Board and Tuwharetoa Settlement Trust for their scholarships and grants.

Finally, I am also extremely grateful to my immediate whānau, my parents Francis and Jolene Grace for their love, encouragement, support, belief and babysitting my kids throughout my study. My parents have never let me be complacent and provided me 
with opportunities that have taken me from Otara, around the world and back to Waikato. My brother and his wife, Dean and Desiree Grace who are an important ongoing support for me and my whānau and my sister Mirimata Frost and her whānau for coming along for the ride.

This research is not possible without my husband, Matiu Payne who has endured, tolerated, supported, and believed in my journey. I am extremely grateful for his patience and mopping up the many tears during my study. My children, Tre, Tūrāhui and Tāne, who have also been patient and tolerant throughout, thank you for everything.

In addition, it should be noted that Māori words are not italicised in this thesis and translation for Māori words can be found in the Glossary.

Photo 2: Te Ao Mārama (at a later age) with her great granddaughter and namesake, Linda Te Ao Mārama Puru

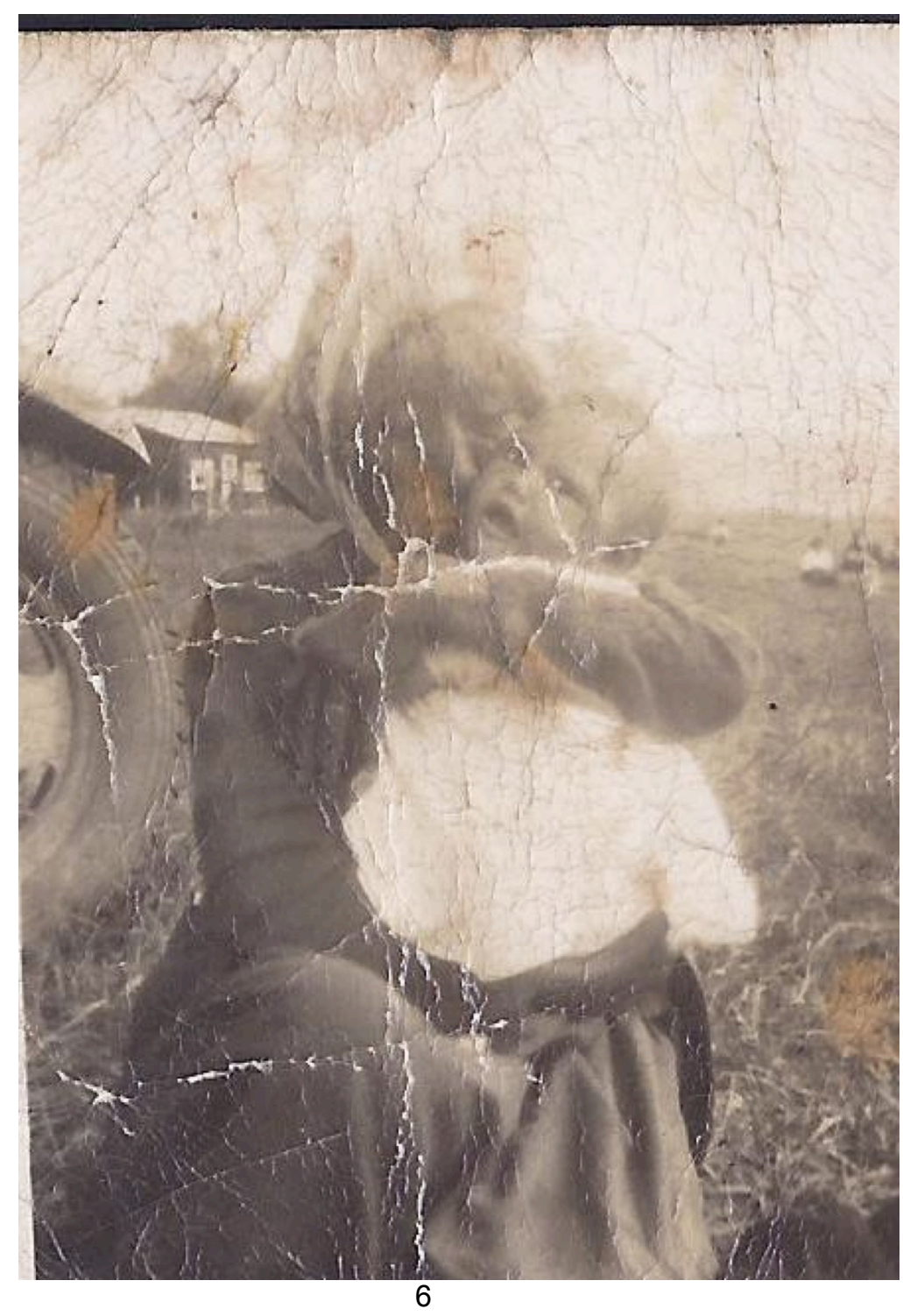




\section{Table of Contents}

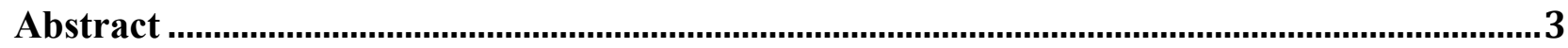

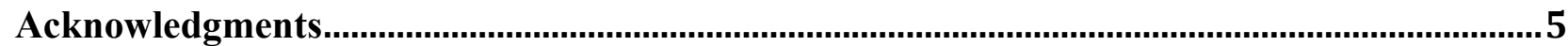

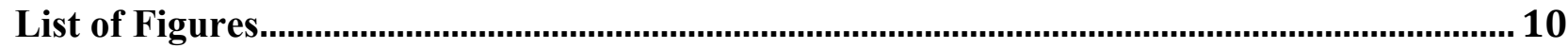

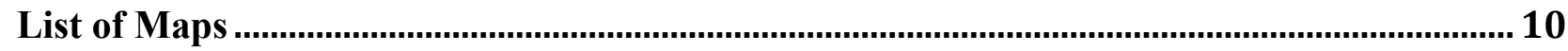

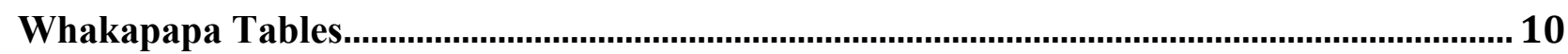

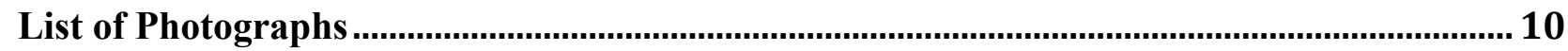

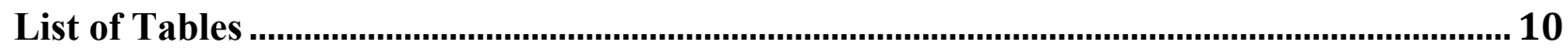

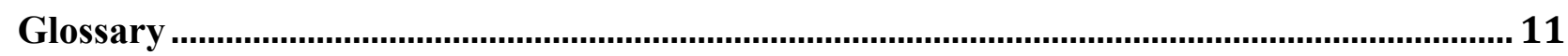

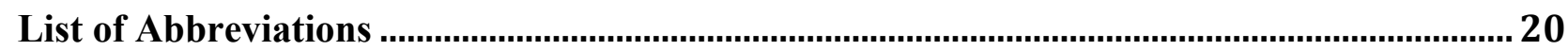

CHAPTER ONE: TE NGIRA O PŌTATAU - INTRODUCTION ........................................ 21

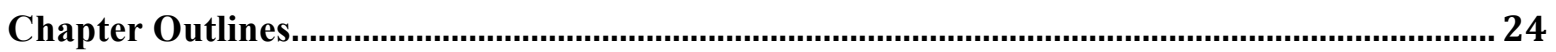

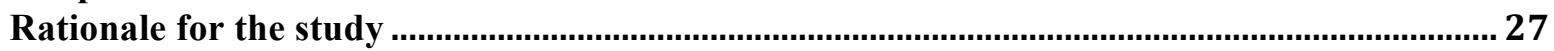

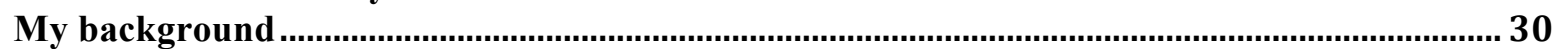

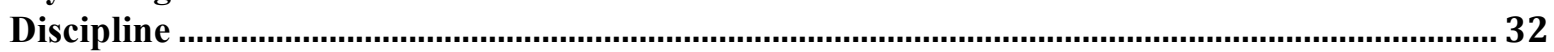

CHAPTER TWO: TE WHARE TONGIKURA .................................................................... 35

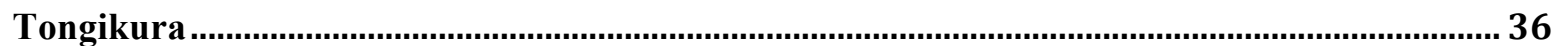

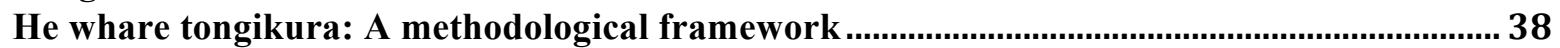

Māku anō e hanga i tōku nei whare: Māori historiography ...................................................... 41

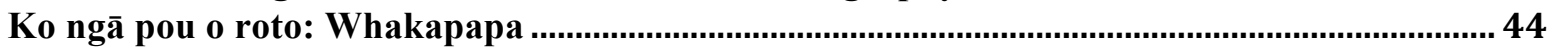

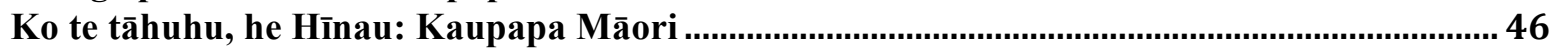

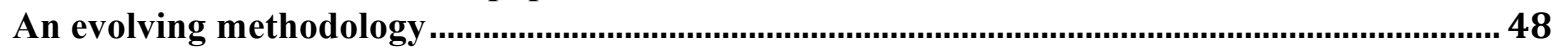

Me whakatupu ki te hua o te Rengarenga: Ahuwhenua .............................................................50

Te Whare Tongikura as a transformative process................................................................56

Me whakapakari ki te hua o te kawariki: Research methods .................................................. 58

CHAPTER THREE: MAI RANGIRIRI - COLONISATION ............................................ 61

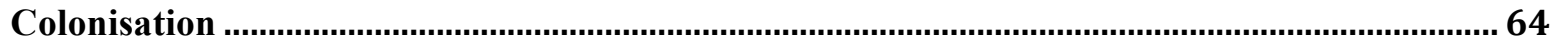

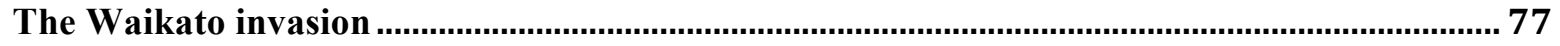

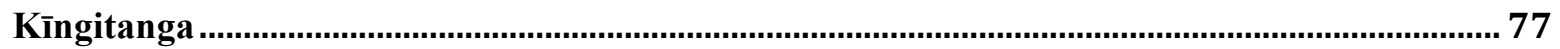

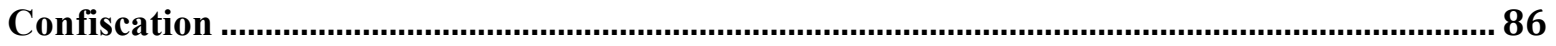

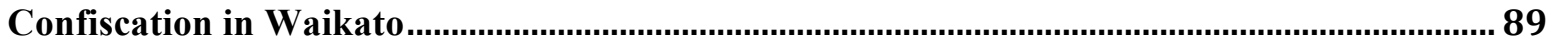

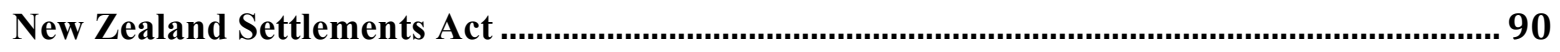

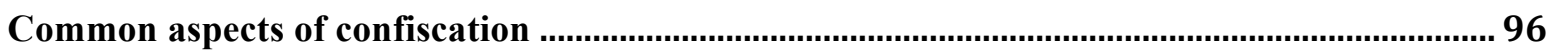

CHAPTER FOUR: NGĀ TARI RAUPATU - AGENTS OF ALIENATION........................101

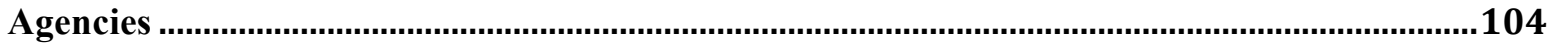

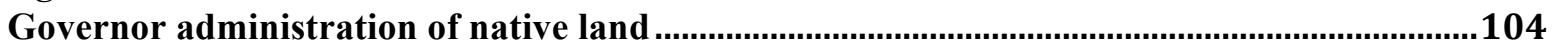

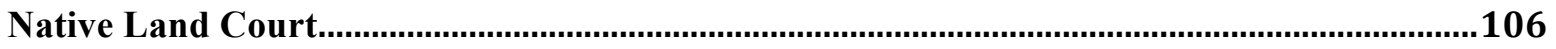

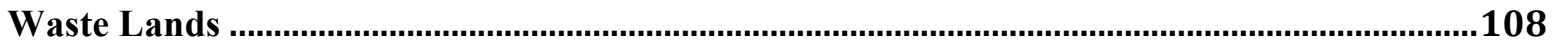

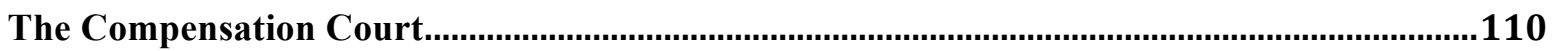

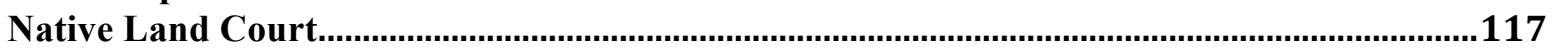

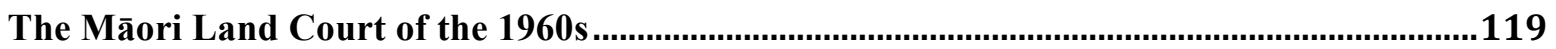

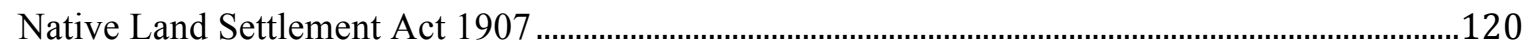

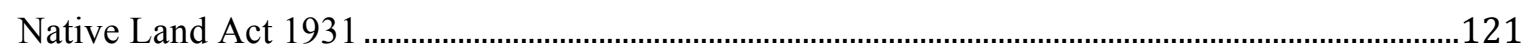

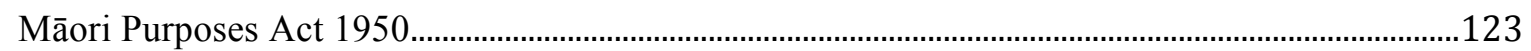

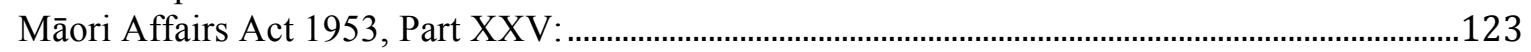

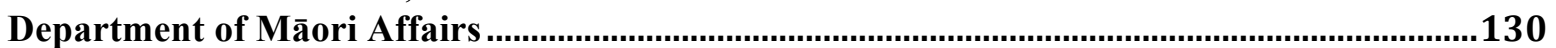




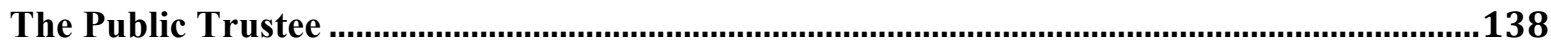

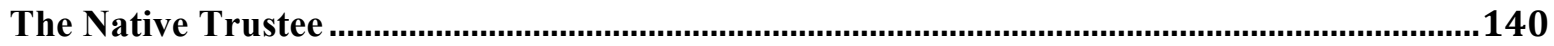

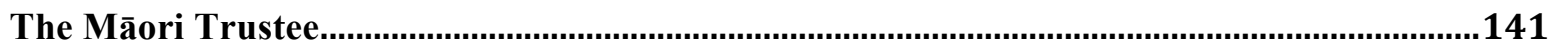

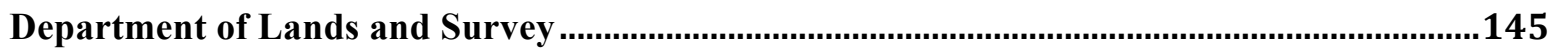

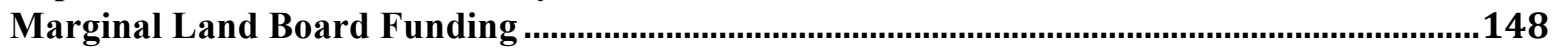

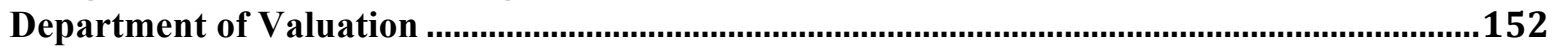

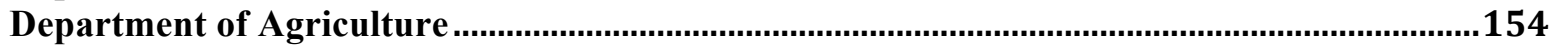

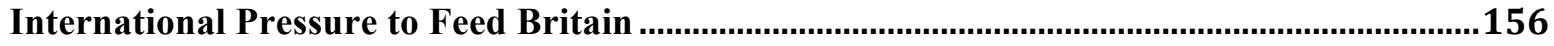

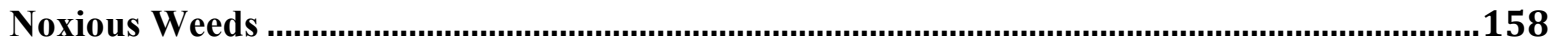

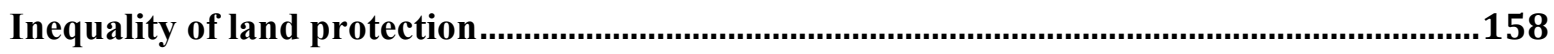

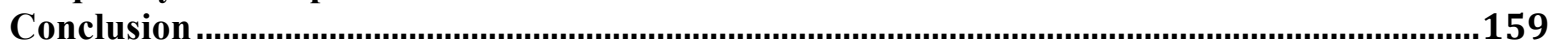

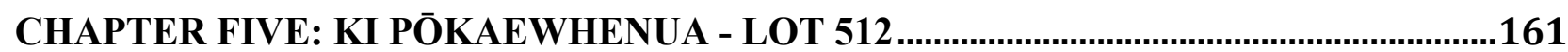

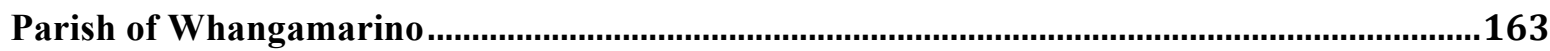

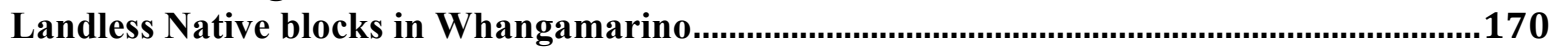

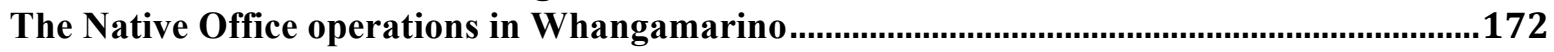

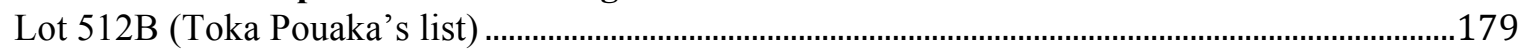

Lot 512C (Tarehurangi te Waari's list) ………………......................................................................179

Lot 512D (Te Ao Mārama's list) ....................................................................................................179

Lot 512E (Wiri te Tiere's list) ...............................................................................................................179

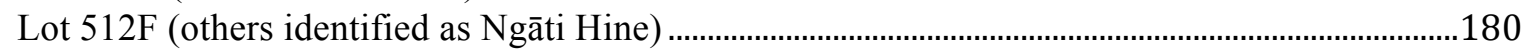

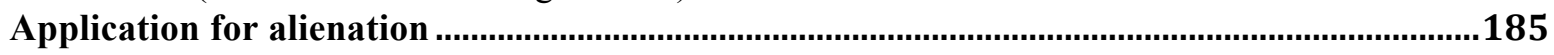

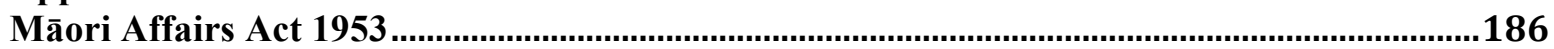

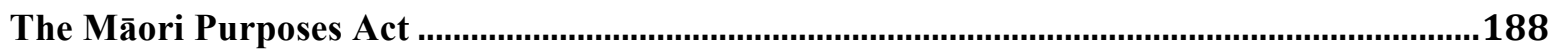

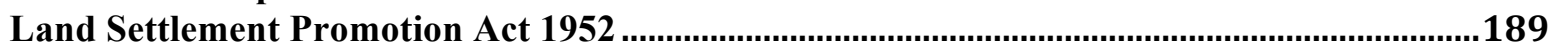

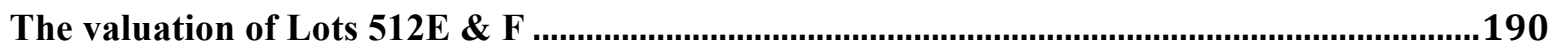

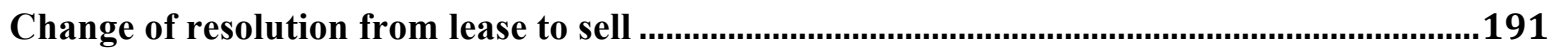

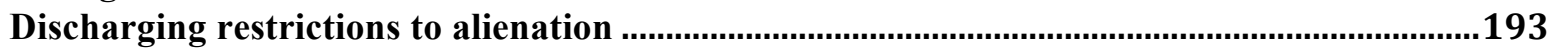

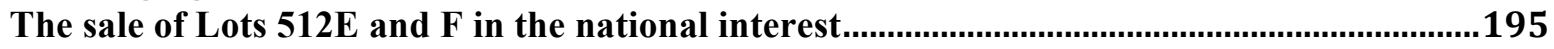

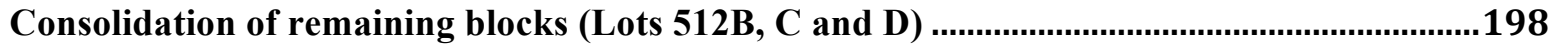

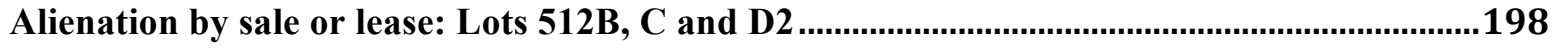

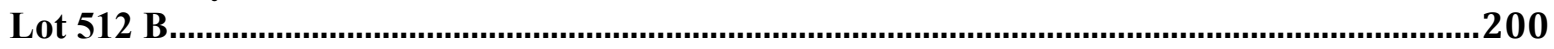

Lot 512 C

Lot 512 D 2

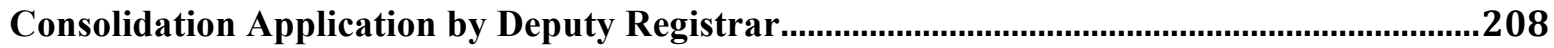

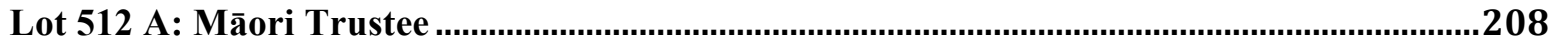

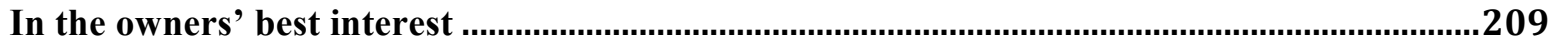

Lot 277

In the national interest

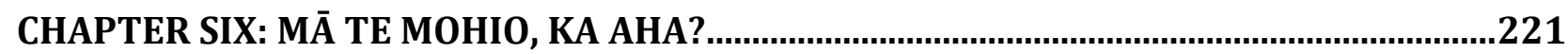

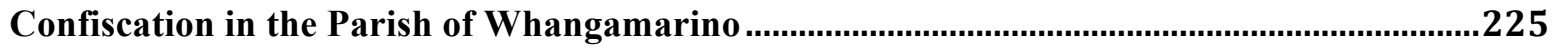

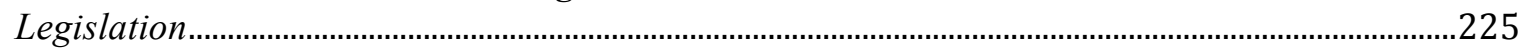

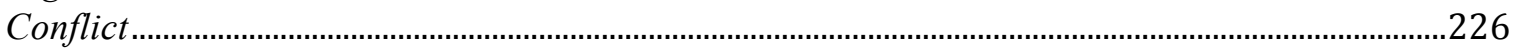

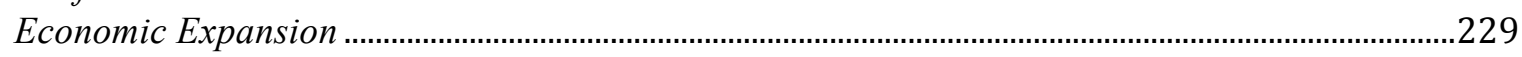

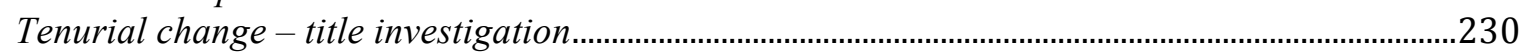

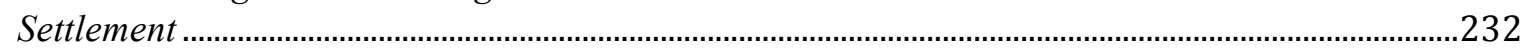

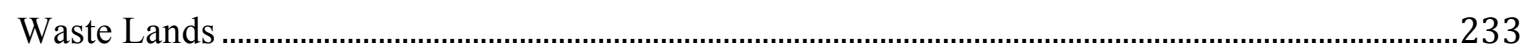

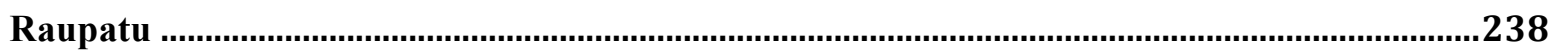

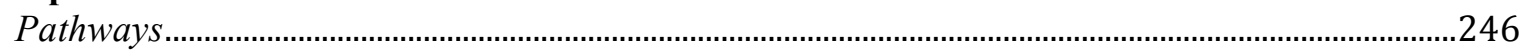

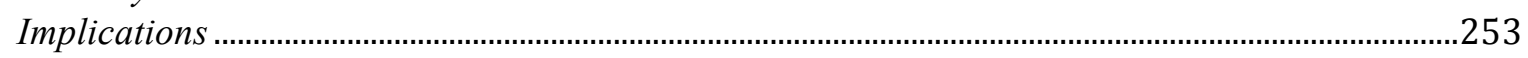

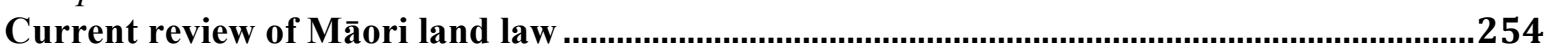

CHAPTER 7: MĀ TE MŌHIO, KA EA: CONCLUSION .................................................259 
BIBLIOGRAPHY 


\section{List of Figures}

Figure 1: Influencing Alienation - the Agents of Alienation

\section{List of Maps}

Map 1: Parish of Whangamarino 22a

Map 2: $\quad$ Map of redoubts in Lower Waikato 62

Map 3: $\quad$ Area confiscated in the Waikato under the New Zealand Settlements Act 1863

Map 4: $\quad$ Pōkaewhenua - Lot 512 Parish of Whangamarino 177

Map 5: $\quad$ Pōkaewhenua - Lot 512 with whare locations 181

\section{Whakapapa Tables}

Whakapapa 1: Genealogy to Te Ao Mārama 29

Whakapapa 2: Te Ao Mārama whānau 213

\section{List of Photographs}

Photo 1: $\quad$ Te Ao Mārama Te Puru (nee Tamehana) 2

Photo 2: $\quad$ Te Ao Mārama with her great-granddaughter Linda Te Ao Mārama Puru

Photo 3: George T Wilkinson

Photo 4: $\quad$ Te Ao Mārama whānau: Umawera, Kauia, Kahutoroa,

Te Ao Mārama

\section{List of Tables}

Table 1: $\quad$ Brad Totorewa Tongikura framework 39

Table 2: $\quad$ Te Whare Tongikura $\quad 57$

Table 3: $\quad$ Return showing the acreage of land held by the Crown through Confiscation

Table 4: $\quad$ Māori land alienated in the Waikato District under the Māori 


\section{Glossary}

Agents of alienation Refers to those government departments in New Zealand that facilitate the alienation of Māori land

Ahi $k \bar{a}$ burning fires of occupation - title to land through occupation by a group, generally over a long period of time.

Ahuwhenua be industrious, productive, diligent, also agriculture, land development

Aroha ki te tangata

a respect for people

Aruhe

edible rhizome of bracken-fern, fern root

Aukati

order, boundary marking a prohibited area, roadblock

Awa river, stream, creek, canal, gully, gorge, groove, furrow

Cambridge Town in the Waikato region approximately 24 kilometres southeast of Hamilton

Cape Colony A colony established by the Dutch East India Company in 1652 and later occupied by Britain in 1795 until 1931, when it became the Cape Province as part of the Union (now Republic) of South Africa.

Drury Rural town 36 kilometres south of Auckland city

Eglinton Redoubt military post four kilometres south of Pokeno

Esk Redoubt located between Miranda and Pokeno

hapū

A collection of inter-related whānau commonly referred to as sub-tribe.

Hapuakohe The mountain ranges on the eastern border between Waikato and Hauraki. Also the eastern confiscation line following the New Zealand Wars.

Hauraki A collection of inter-related hapu that inhabit the Hauraki and Coromandel Peninsula, that has interrelated whakapapa with the Waikato iwi given their members trace their whakapapa to the Tainui waka.

Hīnau Elaeocarpus dentatus tree

Hingakākā the site of a major battle held at Lake Ngāroto between Taranaki and Waikato 
Ниа

hui

Hunua ranges

iwi

Kaka

kai

Kāi Tahu

Kaiaua

Kaikomako

Kainga

Kainga nohonga

Kanohi kitea

Karanga

Kaua e mahaaki

fruit, product, berry, roe, egg

Gathering or meeting

a range of hills 50 kilometres southeast of Auckland see Map 2

People, or a collection of inter-related hapū.

large native forest parrot

Food

A specific group of inter-related hapū who inhabit the South Island of New Zealand.

a small town situated in the Firth of Thames

Pennantia corymbosia tree

home, address, residence, village, habitation, habitat

a place of residence where one is in occupation

importance of meeting face to face

to call, call out, shout, summon, also formal call or ceremonial

call of welcome

Kaua e takahi te mana o te tangata don't trample on the mana of the people, feedback to your community

Kauati friction stick

Kauhanganui the parliament set up by Tāwhiao and the Kīngitanga at Maungākawa, near Cambridge about 1889-1890

kaumātua $\quad$ Elder or leader of a whānau

Kaunoti platform to make friction fire

Kaupapa Māori Māori ideology, philosophical doctrine, incorporating the knowledge, skills, attitude and values of Māori society.*

Kauri Agathis australis tree

Kawariki large-leaved coprosma, Coprosma grandifolia

Kāwhia Habour town, 40 kilometres southwest of Hamilton

kererū New Zealand pigeon, kererū, Hemiphaga novaeseelandiae

kia tūpato culturally safe, politically astute, reflective practice

kiekie Freycinetia baueriana ssp. banksii - a thick native vine which has long leaves with fine teeth crowded at the end of branches

kiwaha A proverbial saying 
Kingitanga

Kiwi

Koha

Koheroa

Kohimarama

kono

kōrero

Koroki (King)

Kouka

kuia

mahau

mahinga kai

Mahoe

Maketu

mana

Manaaki

Manaaki ki te tangata

Mangatāwhiri

Maniapoto

Māori
King Movement - a movement which developed in the 1850s, culminating in the anointing of Pōtatau Te Wherowhero as King. Established to stop the loss of land to the Colonists, to maintain law and order, and to promote traditional values and culture Apteryx australis - flightless, nocturnal endemic birds contribution of consequence The name of a Ridge and a Redoubt between Pokeno and Mercer in the Lower Waikato.

A coastal residential Auckland City suburb, located to the east of the city.

Flax basket ordinarily used for food.

To speak, to say, to have spoken.

the fifth Māori King

Cordyline australis - a palm-like tree with strong, long, narrow

leaves. The young inner leaves are eaten both raw and cooked

An elderly woman, or maternal leader in the whannau

porch or verandah of a wharenui

Refers to traditional food or other natural resources, as well as the practice of harvesting food, or places where those resources are located.

whiteywood, Melicytus ramiflorus - a common tree in regrowth and coastal bush

Small town in the Bay of Plenty area

Individual or collective authority reinforced by people.

to support, take care of, give hospitality to, protect, look out for Working collaboratively. To look after each other. To look after people.

Place and stream, north of Tuakau. The Mangatāwhiri Stream represented the aukati in 1863 for the Kinngitanga

See Ngāti Maniapoto

A common name that refers to all whānau, hapu, and iwi in New Zealand. Also used to distinguish those government departments 
Marae

Maramarua

Matahuru

matua atawhai

maunga

Maurea

Mercer

Meremere

Miranda Redoubt

Moana

mokopuna

moni toto

Muru

Ngaruawahia

National interest alienation land alienation by a government department in the nation's best interest.

Native

Native Assessor

or agencies that are specifically responsible for policies affecting whānau, hapū and iwi.

a complex of buildings that provide a space for whānau, hapū and iwi to undertake customary or traditional celebrations or events. It commonly consists of a wharenui and wharekai.

A small town in the Waikato area on State Highway 27. Also the name of the Crown forest in the immediate vicinity of Lot 512.

Small rural area, east of Lake Waikare

Foster parent (a dialectal form of matua whāngai)

mountain, and as part of pepeha refers to sacred mountain

Area and name of Marae on the western side of the Waikato

River, west of Rangiriri

Small town in Lower Waikato on State Highway 1, south of

Pokeno

Small town in Waikato, south of Pokeno and north of Ohinewai

military post at Miranda, a rural town in the Hauraki Habour -

also known as Pukorokoro

sea, ocean, large lake

Grandfather

a kiwaha that refers to money given for confiscated land, or figuratively used to describe confiscated land returned to Māori.

to plunder, confiscate, take ritual compensation an effective form of social control, restorative justice and redistribution of wealth among relatives.

A town in Waikato situated on State Highway 1 between Taupiri and Hamilton

a term legislatively and commonly applied to Māori, particularly during the $19^{\text {th }}$ century. Also applied to agencies responsible for policy pertaining to Māori.

an Assessor appointed to the Native Land Court and Native Department to assist in administrating and the granting of Māori land 
Ngā Rauru Kiitahi A collection of inter-related hapu that inhabit the Whanganui area.

Ngāti Awa

A collection of inter-related hap $\bar{u}$ that inhabit the Whakatane, Kawerau, Te Teko and Matata areas.

Ngāti Hape

A collection of inter-related whannau that inhabit the Hauraki region

Ngāti Haua

A collection of inter-related hap $\bar{u}$ that inhabit the eastern

Waikato area

Ngāti Hine

A collection of inter-related whannau that inhabit the Parish of Whangamarino area in Waikato

Ngāti Mahuta

A collection of inter-related whānau that originate from Kāwhia and inhabit the Waikato area.

Ngāti Maniapoto an $i w i$ based in the Waitomo region that have interrelated whakapapa with the Waikato iwi given their members trace their whakapapa back to the Tainui waka.

Ngāti Marae

A collection of inter-related whānau that also inhabit the Waikare and Hauraki region.

Ngāti Mutunga

A collection of inter-related hap $\bar{u}$ that inhabit the north Tarakai region

Ngāti Naho

A collection of inter-related whannau that also inhabit the Waikare area and the Parish of Pepepe rohe.

Ngāti Pahauwera A collection of inter-related hapū that inhabit the Mohaka area

Ngāti Porou

A collection of inter-related hapu that inhabit the East Cape and Gisborne region

Ngāti Pou

A collection of inter-related whānau that inhabited the Whangaroa area.

Ngāti Ruanui

A collection of inter-related hap $\bar{u}$ that inhabit the Taranaki region

Ngāti Tama

A collection of inter-related hapu that inhabit the north Taranaki area

Ngāti Te Ata

A collection of inter-related hapu that inhabit the Waiuku and Awhitu area.

Ngāti Turangitukua A collection of inter-related whānau that inhabit the Turangi township area

Ngāti Tuwharetoa A collection of inter-related whānau that inhabit the Taupo region 
Ngāti Whānaunga A collection of inter-related whānau that inhabit the Hauraki area ohaki An oral will imparted by a dying Rangatira in the company of close relatives.

Ohinewai Small town north of Huntly.

Okarea

A marae on Jamieson Road, in Waerenga that associates with Ngāti Hine and Ngāti Mahuta.

Orakau is a small rural area on the Puniu River approximately 5 kilometres from Kihikihi, new Te Awamutu. It is also the site for the last battle in Waikato before the hostilities ended.

Paetai Is an area situated in Rangiriri where a major hui of Rangatira was held to discuss the impending invasion of Waikato

Pai marire the Christian faith developed by Te Ua Haumēne in Taranaki which is still practised by some, including Waikato Māori.

Pākehā Commonly refers to non-Māori, although more specifically to those originating from, or with whakapapa to England and Europe.

Parish of Koheroa Parish immediately north of the Maramaraua River

Parish of Pepepe Parish immediately west of the Parish of Whangamarino

Parish of Taupiri Parish immediately south of the Parish of Whangamarino

Parish of Whangamarino The administrative land mass that encompasses the Waikare area and various hapū including Ngāti Hine, Ngāti Naho, Ngāti Marae and more recently, Ngāti Mahuta

Parley discussion or conference between enemies during war

Pāterangi Small town northwest of Te Awamutu and site of a fortified pa that was built during the invasion of Waikato.

Papatipu land under customary title, ancestral land - the base upon which the hapū was nurtured*

Pātaka Storehouse raised upon posts, pantry, larder

Patate $\quad$ Schefflera digitata - a small forest tree which has hand-shaped leaves with fine teeth and three to nine 'fingers'

Pepeha tribal saying, proverb (especially about a tribe), set form of words, formulaic expression, figure of speech, motto, slogan

Pirongia a small town approximately 14 kilometres from Te Awamutu 
Pōhutukawa

Pōkaewhenua

Pokeno

Port Waikato

Pou

Pouakani

Pukawa

Pukekamaka

Pukorokoro

pūrākau

Queen's Redoubt

Raglan

Rangatira

raupatu

rangatiratanga

Rangiaowhia

Rangiriri

Rebels

Rengarenaga
Metrosideros excelsa, Metrosideros kermadecensis, Metrosideros bartlettii - trees found in coastal areas which bear large, red

flowers about Christmas time

The ancient $\mathrm{Pa}$ on Lot 512

Small town in Waikato south between Drury and Mercer

is located southwest of Tuakau and also where the Waikato River empties out into the Tasman Sea

pillars or support posts

located southeast of Mangakino, predominantly around the Pureora Forest.

Small town on the southern shores of Lake Taupo, as well as the place where Tāwhiao stayed while in exile from the Waikato.

Also a mission station where Thomas Samuel Grace was

stationed

A mountain of importance to those from Okarea marae

Māori name for Miranda

Traditional narratives.

located in Pokeno and the site of one of the largest forts for the invasion of Waikato

located 50 kilometres west of Hamilton on the coast.

A binder of people, a chief or leader.

taken by force of arms during conflict, the blade of the patu, or confiscation.*

Chiefly autonomy, self-governance.

located southwest of Te Awamutu and the site of a military

ambush and masacre by the Colonial forces during the invasion of Waikato

A small town in the Waikato area, south of Auckland. Also a major battle site during the New Zealand Wars.

Refers to those considered by the Crown to be in armed conflict against its authority.

Arthropodium cirratum - a native plant with light green, broad and strap-like, glossy leaves and white flowers with yellow and purple centres 
Res nullius

Rimu

riro

tāhuhu

Tai Tokerau

Takapūruharuha

Take

take noho

take raupatu

take taunaha

take tuku

take tūpuna

take whenua

takiwā

Tangata whenua

taonga

Tangoao

Taranaki

Taupiri

Tauranga

taurima

Te angitu

Te Riu o Waikato
Land that has been abandoned by its owners, in particular indigenous owners.

red pine, Dacrydium cupressinum

to be gone, departed, set out*

ridge pole (of a house)

A term used to refer to the northern geographical tip of the North Island of New Zealand.

pa site for Ngāti Hine, situated at Lot 393 in the Parish of

Whangmarino

reason, purpose, cause, origin, root, source, beginning*

One subset of take whenua that is based on rights arising from occupation

One subset of take whenua that is based on rights arising from conquest

One subset of take whenua that is based on rights arising from naming places

One subset of take whenua that is based on rights arising from gift or release

One subset of take whenua that is based on rights arising from ancestry.

A term used to describe the collective philosophies associated with Customary Māori Land Tenure. Literally, the "basis of land or birth"

district, area, territory, vicinity, region

Refers to Māori who are of New Zealand.

Treasured things.

Marae situated on Lot 473 in the Parish of Whangamarino

Sacred mountain in the New Plymouth area

Small town south of Huntly and north of Ngaruawahia. Also the name of the sacred maunga of Waikato.

largest city in the Bay of Plenty region

A dialectal form of whāngai favoured by Taranaki people

striving for success

A collaboration of hapū in the Lower Waikato region 
Te Roroa

Te take o te kōrero the main purpose of the discussion

Te Wao nui a Tāne the forest

Te Wheoro's redoubt located at Rangiriri

terra nullius

tikanga

Tūpuna

titiro

Titiro, whakarongo, kōrero to look, listen, speak

Tongikura

Tōtara

Tsalagi

$T \bar{u} \bar{\imath}$

Waerenga

Waikare

Waikato

Waikato-Tainui

Waitangi
Latin expression meaning "land belonging to no-one" although used as a means of explaining the lack of stationary existence by indigenous people and thereby lacking ownership of their land. customs and protocols. Can refer to tikanga Māori (Māori customs and protocolos), iwi tikanga (tribal customs and protocols).

$$
\text { ancestor }
$$

To look, to see. a prophetic saying predominantly ascibed to Tāwhiao

Podocarpus totara, Podocarpus cunninghamii - large forest trees with prickly, olive-green leaves another name for Cherokee - a Native American people who once inhabited the Appalachian Mountains parson bird, Prosthemadera novaeseelandiae - a songbird that imitates other birds' calls

A small town in the Parish of Whangamarino located east of Te Kauwhata

The region encompassing the Parish of Whangamarino and name of a lake in that same region

A collection of inter-related hapu that inhabit the South Auckland and Waikato region of New Zealand that have interrelated whakapapa with the Hauraki and Maniapoto iwi given their members trace their whakapapa back to the Tainui waka.

The common name that refers to the Waikato iwi and affiliated iwi such as Raukawa, Hauraki and Ngāti Maniapoto, particularly post Settlement.

A small township north of Paihia. The place where the Treaty of Waitangi was signed. The name used for the Tribunal that hears Treaty grievances ie Waitangi Tribunal. 


$\begin{array}{ll}\text { Waka } & \text { wooden canoe } \\ \text { Wänanga } & \text { to meet and discuss } \\ \text { Weka } & \text { woodhen, Gallirallus australis - a brown-feathered endemic bird } \\ \text { Whakaaro } & \text { Thought, idea, ideal } \\ \text { whakapapa } & \text { Interconnectedness, genealogy } \\ \text { whakarongo } & \text { To hear, to listen. } \\ \text { Whakatauki } & \text { proverb, saying, cryptic saying, aphorism. } \\ \text { whänau } & \text { A Māori family unit, and also to give birth. } \\ \text { whänaungatanga } & \text { Creating and maintaining inter-personal relationships. } \\ \text { whāngai } & \text { To feed, nourish. It is the customary term used to encompass the } \\ \text { practise of customary Māori adoption. } \\ \text { Ahangamarino } & \begin{array}{l}\text { A river south of Meremere. An area formed into a Parish whose } \\ \text { boundaries follow the Whangamarino River, east to the }\end{array} \\ \text { Hapuakohe ranges, south to Matahuru stream, across to the Lake } \\ \text { Whenua }\end{array}$

Translations taken from The Māori Dictionary at www.Māoridictionary.co.nz on $13 / 12 / 2013$

\section{List of Abbreviations}

ANZ

AJHR

NZPD

NZG

RDB
Archives New Zealand

Appendix to the Journal of the House of Representatives

New Zealand Parliamentary Debates

New Zealand Gazette

Raupatu Document Bank 


\section{CHAPTER ONE: TE NGIRA O PŌTATAU - INTRODUCTION}

Kotahi te kohao o te ngira e kuhuna ai, te miro ma, te miro pango, te miro whero. A muri i a au, kia mau ki te ture, ki te whakapono, ki te aroha. Hei aha te aha! Hei aha te aha!

There is only one eye to the needle through which the white, black and red threads must pass. After I am gone, hold fast to the law, to faith, to love. Nothing else matters nothing! ${ }^{1}$

Pōtatau Te Wherowhero was reluctantly crowned King in 1858 following a round of hui culminating in a gathering at Pukawa where Pōtatau was asked to lead the Kīngitanga Movement. The Kīngitanga Movement was established after increased pressure from settlers for Māori land and the waiving of Crown pre-emption. The Kīngitanga was not perceived by Pōtatau or those Rangatira that supported the Kīngitanga to be a challenge to the Crown, but rather to maintain law and order and stop all further land sales, particularly in the Waikato. ${ }^{2}$ On the $25^{\text {th }}$ of June 1860 , Pōtatau died after serving for just over a year. ${ }^{3}$ Before his death, Pōtatau left the above warning for his son that symbolised "a message of unity and holding fast to ideals and principles" of the Kīngitanga Movement. ${ }^{4}$ His son, Matutaera was crowned the new King at Pōtatau's funeral and the Kīngitanga's policy to stop all sales of Māori land continued inciting hostility amongst the Crown and settlers, and by 1863 the Crown had gathered their militia and travelled south to the Waikato.

Matutaera (now named Tāwhiao following his Coronation) established the aukati at Mangatāwhiri which was ignored on 12 July 1863 when the Colonial army crossed the Mangatāwhiri stream ${ }^{5}$ leading to the battle at Rangiriri on the $20^{\text {th }}$ of November 1863. The battle of Rangiriri continues to resonate with Waikato Māori. A recent 150 year commemoration on 20 November 2013 involved a full re-enactment of the battle,

\footnotetext{
${ }^{1}$ Office of the Māori King, downloaded from http://www.kiingitanga.com/history on 16 December 2013.

${ }^{2}$ David McCan, Whatiwhatihoe: The Waikato Raupatu Claim, Wellington, Huia Publishers, 2001, p.32.

${ }^{3}$ Turongo House, Täwhiao - King or Prohet, MAI Systems Ltd, 2000, p. 42.

${ }^{4}$ Office of the Māori King, downloaded from http://www.kiingitanga.com/history on 16 December 2013.

${ }^{5}$ Dean McCan, Whatiwhatihoe, p.47.
} 
undertaken by over 200 Māori male and female warriors and included the depiction of murdered children and colonial militia. The event was attended by over 1,000 people and evoked strong feelings of loss, anger and bitterness, while at the same time celebrating the continued survival and development of the iwi.

It was this battle at Rangiriri that defined the invasion of Waikato which signified the first significant loss of Waikato men, women and children, the loss of land and the beginning of the government machinery including surveyors, the Native Land Court, Compensation Court and Native assessors who would hence forth determine whether 'rebel' Waikato Māori were eligible to occupy their own land.

The title of this thesis, Mai Rangiriri ki Pōkaewhenua, refers to the battle of Rangiriri as the point of reference, which marks the first confiscation of Waikato land. It was at Rangiriri that Waikato Māori took up arms to defend their land against the invading army and in doing so, by Crown law, forfeited their customary ownership over their land through confiscation. It would be one hundred years later that another confiscation would occur at Pōkaewhenua in the 1960s.

Pōkaewhenua is situated at the northeastern most point of the Parish of Whangamarino and is located within the Ngāti Hine ki Waikato hapū takiwā (see Map 1). Pōkaewhenua is an old pā site on the direct pathway between Waikato and Hauraki. Pōkaewhenua was inhabited by both Ngāti Hine and Ngāti Marae but is also associated with other hapū such as Ngāti Mahuta who married into the hapū, as part of the migration of Ngāti Mahuta out of Kāwhia. Despite this, Ngāti Hine has had unbroken take tūpuna and take noho in Pōkaewhenua and Waikare with documented accounts as early as 1807 when Ngāti Hine went to battle with Te Rauangaanga (father of Pōtatau Te Wherowhero) against Te Rauparaha at Hingakākā. ${ }^{6}$

Lot 512 is a land block on Pōkaewhenua that was granted to Ngāti Hine in 1927, following forty years of investigation by the Native and Māori Land Courts. In 1914, there were 512 Lots in the Parish of Whangamarino, which encompassed 95,775 acres,

\footnotetext{
${ }^{6}$ Pei Te Hurinui Jones, King Pōtatau, Wellington, Journal of the Polynesian Society, 1959, p 46. See also Leslie G. Kelly, Tainui, Wellington, The Polynesian Society (Inc.), 1949, p.237 for the date of Hingakākā.
} 
all of which were confiscated following the invasion of Waikato during the $1860 \mathrm{~s}$. After the creation of the Native Land Court and the Compensation Court, approximately 6,663 acres was set-aside within the Parish for Waikato Māori. In 1910, 4,073 of those acres were set aside in 19 blocks and advertised in the New Zealand Gazette for title investigation. Those entitled to the 19 blocks were Māori considered to have been landless rebel natives following the invasion of Waikato. Lot 512 was one of those blocks set aside as a Native Reserve and as early as 1883, was promised to Ngāti Hine by the local Native Assessor given their occupation and utilisation of the land prior to the invasion of Waikato and the Treaty of Waitangi.

In 1930, Lot 512 was partitioned by the Māori Land Court into six parcels named A-F and by 1969, all six blocks were alienated by the Māori Land Court in the national interest. The rationale applied by the Māori Land Court for alienation was a failure by Māori owners to productively utilise the land and as a result the sitting Judge declared Lots 512E and F waste land. Although the declaration of these blocks as waste land in the 1960s was out of step with Māori Land Court practice of the time, Lots 512E and F were sold with the remainder of Lot 512 subsequently alienated by lease despite owners still living and providing for their own livelihoods there. Currently, four acres are set aside in Lot 512D for a marae complex and urupā, with one unpermitted building used intermittedly by a whānau member. One acre has been partitioned as Lot 512A1, while the remainder of Lot $512 \mathrm{~A}, \mathrm{~B}, \mathrm{C}$ and $\mathrm{D}$ have been in lease since the original eviction of its owners in the 1960s.

This thesis investigates the alienation of Lot 512 and poses the following questions: firstly, is the alienation of Pōkaewhenua - Lot 512 in the national interest confiscation? If so, then secondly, what remedial action, if any, is available to its Māori owners? To answer these questions I will investigate the process and practice of a facilitated sale including concepts such as waste land, productivity, national interest, the agencies involved in alienation and also whether national interest alienations are confiscation.

For the purposes of this thesis, Pōkaewhenua and Lot 512 are used interchangeably given the name of the wharenui on Lot 512, the stream running alongside Lot 512 and the pā site on Lot 512 are all named Pōkaewhenua. The name Okarea is also used to 
refer to the common name of the area around Pōkaewhenua and the common reference to the marae on Pōkaewhenua.

The term alienation in this thesis refers to the dispossession of land by either sale or lease. As an ongoing policy of the Government in the nineteenth and twentieth century, alienation has been referred to in legislation as early as 1865 in determining the restrictions or conditions of Māori land alienated by sale or lease. In the current Te Ture Whenua Māori Act 1993, any type of dispossession of Māori land in any form is considered alienation.

It is my contention that in answering the questions outlined above, a gap exists in the current literature as it pertains to Māori land in the Waikato, and Lot 512 in particular. My premise is not that there is little or no research on the concepts of national or indigenous interests, waste lands or (Māori land) productivity, but rather that the application of these concepts as a whole, in a specific geographic location in conjunction with confiscation and compensation has yet to be explored. These concepts individually have been written about extensively ${ }^{7}$ and where some conceptual collaboration has occurred (that is the concept of national and Māori interests) in the main, these are explained in macro terms and seldom investigated at a local, geographically specific area, concerning a particular subset of the community. I argue that the alienation of Lots $512 \mathrm{E} \& \mathrm{~F}$ provide an opportunity to investigate how national interest alienations occurred, the affect it had on its owners, the impact his alienation had on the remaining blocks of Lot 512 and whether that alienation is a type of confiscation.

Little is currently known about Lot 512 and its history, particularly as a compensation block and its facilitated alienation in the 1960s. Although there is a marae situated on Lot 512D2 for the Ngāti Hine hapū, it was not until the building of the whare kai at Okarea in $2010^{8}$ that whānau became more interested in its history.

\section{Chapter Outlines}

\footnotetext{
${ }^{7}$ See Richard Boast (1993, 2004, 2004b, 2008, 2009, 2010a, 2010b), David Williams (1999), Bryan Gilling (1994, 2001, 2007, 2009).

${ }^{8}$ Note that Okarea is also known as Okaeria but is commonly pronounced as it is written. For that reason,

"Okarea" will be used throughout, even though on current maps it is spelt Okaeria.
} 
This introduction has stated the research question that will be answered in this research: is the facilitated alienation of Lot 512 confiscation and if so, what remedy, if any is available to its owners? A brief outline of Pōkaewhenua has been provided and its relatedness to Ngāti Hine and the Parish of Whangamarino. Both the hapū of Ngāti Hine and the Waikato iwi will be the focus throughout this thesis.

The main theme of my research explores the utilisation and productivity of Māori land for the benefit of whānau, hapū, community, the nation and international markets. Each chapter explores the notion of 'productivity' within the timeframe outlined in each chapter and discusses how the perceived notion of waste land (its polar opposite) was applied to Māori land. It is my assertion that land productivity was the key focus of government policy for the alienation of Māori land in the 1860s as well as the 1960s in Pōkaewhenua.

Chapter Two sets out the methodological framework that is used throughout this thesis. The framework utilises Ngā Tongikura o Tāwhiao by weaving different methodologies and concepts together to tell the story of Pōkaewhenua and Ngāti Hine. Tāwhiao's most well known tongikura explains the building of a whare utilising the resources that remained following the invasion of Waikato. Tâwhiao points to the mahoe, patatē, tāhuhu, hīnau, rengarenga and kawariki as resources that Waikato was to use to both shelter and feed themselves. The tongikura is recited as follows:

Māku anō e hanga i tōku nei whare. Ko ngā pou ō roto he mahoe, he patatē.

Ko te tāhuhu, he hīnau. Me whakatupu ki te hua o te rengarenga.

Me whakapakari ki te hua o te kawariki. ${ }^{9}$

I shall fashion my own house. The support posts shall be of māhoe and patatē. The ridge-pole is of hīnau. The inhabitants shall be raised on rengarenga and nurtured on kawariki.

\footnotetext{
${ }^{9}$ Nā Tāwhiao Matutaera Te Wherowhero in Brad Totorewa, 'A Review of the Rights of First Refusal within the 1995 Waikato-Tainui Raupatu Settlement', unpublished Major Research Project paper for the Masters of Business Administration, University of Waikato, 2013, p.10.
} 
The methodology chapter brings together Kaupapa Māori, Māori historiography, whakapapa and Ahuwhenua (or land productivity). In the main, this research sits more comfortably with Kaupapa Māori given the subject matter is inherently about whānau, hapū and whenua from an insider's perspective. This chapter also explains the structure of each chapter, which is preceded by a tongikura known to have been imparted by Tāwhiao. The tongikura is followed by an explanation of its meaning and the relevance it has to the contents of each chapter.

Chapter Three focuses on settler and colonial development in New Zealand in particular the practice of colonisation and confiscation as it was applied in the nineteenth-century, and the use of the term waste land which had an enduring impact on Waikato. I argue in this chapter that colonisation had a key focus on the acquisition and utilisation of land in particular ways that deemed Māori land use as inferior, wasteful and unproductive. This chapter outlines the lead up to the invasion of Waikato, the confiscation of Waikato land and the processes by which Waikato Māori were provided land grants through the Compensation and Native Land Court. Five practices of confiscation are also outlined as a baseline measurement for considering whether the alienation of Pōkaewhenua was also confiscation.

Chapter Four examines government agencies as 'agents of alienation' by looking at the policies and intersection of the Native and Māori Land Court, other agencies involved in land productivity and alienation, and also provides an outline of the Compensation Court, Public, Native and Māori Trustee, Departments of Lands and Survey, Valuation, Agriculture and Native and Māori Affairs. It is my contention that the agents of alienation identified in this chapter sought to ensure that Māori land was productively utilised in a particular way and where land was found to be otherwise, could be alienated in the national interest.

As the case study for my research, Chapter Five will investigate the alienation of Pōkaewhenau by bringing together the block's experience with the agents of alienation, in particular the policy of productivity and the national interest. This chapter will show how Lots 512E and F were declared waste land and all six partitioned Lots systematically alienated over an eight year period, utilising the criteria set out by Lands and Survey as a basis for minimising Māori attempts to remain in occupation of their 
land. A discussion of Māori interests and the national interests is also undertaken and it is argued in this chapter that the alienation of Pōkaewhenua was confiscation.

Chapter Six recalls the common practices of confiscation and applies them to the case study to show how the facilitated alienation of Lot 512 is confiscation. In doing so, an overview of the recent Waitangi Tribunal settlements is undertaken to compare confiscation terminology and show how confiscation has generally been limited to the nineteenth-century. This chapter argues that confiscation is an enduring practice and land alienation in the twentieth century, through analysis of Lot 512, remains. I explore three pathways and implications of this research and recommend further research be undertaken of national interest alienations in the Parish of Whangamarino and elsewhere. I also argue that the recent Te Ture Whenua Māori Act Review and its focus on Māori land productivity have the potential to undertake further national interest alienations.

\section{Rationale for the study}

The aim of this research is to determine whether the facilitated alienation of Pōkaewhenua is confiscation. Although efforts have been made to ensure all possible avenues have been covered, there were self-imposed limitations to the study that may have influenced the outcome.

The legislation governing Māori land began in 1863 and has evolved to the present. However, the focus of this research is limited primarily to the New Zealand Settlements Act 1863 and the Māori Affairs Act 1953. Other legislation has been touched on to support arguments or show contradictions in government policy, however in the main, the Māori Affairs Act 1953 has been at the centre of this thesis. The rationale for this limitation was due to the alienating provisions provided for Lot 512. Part XXV was implied, through the use of its clauses, while the referring legislation pointed to section 39(12) of the Native Land Amendment and Native Land Claims Adjustment Act 1927, which removed any restrictions placed on the block regarding its alienation. It was inevitable however that the alienation circled back to Part XXV given the criteria utilised is specific to Part XXV. 
Secondly, the research was originally focused on Lots 512E and F. The inclusion of the remaining blocks, Lots 512A-D, provided a wider framework to show confiscation practices were utilised across the block. The inclusion of these other Lots demonstrate how the alienation of the entire block was targeted and utilised a process that marginalised its Māori owners, used criteria that was consistent with nineteenth-century confiscation and had the same end: the alienation of Māori land and the displacement of its owners. However it is acknowledged that the stronger argument of facilitated alienation as confiscation is stronger with Lots $512 \mathrm{E}$ and F.

The focus of this thesis is on one block in the Parish of Whangamarino. This was deliberate. Although there were other blocks identified and some mention of them can be found in this thesis, the ability to access all the information necessary to draw strong comparisons became a distraction. A departmental return in 1964 showed 1800 acres alienated under Part XXV, which highlights the wider implication of this research however continued reflection away from Lot 512 would make this thesis a study of facilitated alienation rather than a study of Lot 512 .

This thesis also focuses on one component of the Māori Affairs Act 1953 - Part XXV. There are other parts of the Act that relate to the consolidation of shares and conversion of shares to the Māori Trustee that had an equally debilitating effect on Māori ownership, but neither are canvassed thoroughly in this thesis. These two avenues of alienation can be similarly described as confiscation however, neither consolidation of owners' interests or conversion of owners' shares were applied to Lot 512.

Another key limitation of this research is its predominant focus on Waikato. Lot 512 is located in Waikato and by virtue of this, the research has maintained its focus there. There are implications for Māori in general and Indigenous peoples elsewhere and although these linkages are shown, these would require another thesis to elaborate on them.

It is important to acknowledge that Waikato had a distinct experience with the Crown. Although there are similar practices of invasion, confiscation and compensation elsewhere, this thesis takes a narrow view of government interaction with a focus on Waikato. There is a strong stance taken when explaining the roles of the agents of 
alienation as it applied in Waikato but it needs to be said that these same agents played positive roles with other whānau, hapū and iwi, including with Te Puea Herangi. ${ }^{10}$ However, this was not the case with Ngāti Hine, in Waikare, at Pōkaewhenua.

Access to specific archival documents was also limited. Reports by Judges Holland (1912) and McCormick (1927) sent to the Chief Judge for consideration, as well as Native Agent, George Wilkinson's' report on Pōkaewhenua - Lot 512 could not be found despite significant assistance from Archives New Zealand staff. ${ }^{11}$ Archivists in Wellington suggest that the Hope Gibbons fire of 1952 destroyed the files so a reliance on Wilkinson's report for Lot 393 is utilised instead. Although Wilkinson's report refers to Lot 393, the ownership list of this block (also a Compensation block investigated at the same time as Lot 512), mirrors the ownership of Lot 512. The awarding of Lot 393 to Ngāti Hine as well as Lot 512 supports this, and is said as much in Wilkinson's reports for Lot 393.

Another focus of this thesis is that despite Ngāti Hine ki Waikato being a recognised hapū of Waikato-Tainui and are signatories to the tribe's Treaty Settlements, the Waikare area has been associated with Ngāti Mahuta since 1995. The intermarriage between Ngāti Hine and Ngāti Mahuta and the strong support of the Kinngitanga

Whakapapa 1: Geneaology to Te Ao Mārama

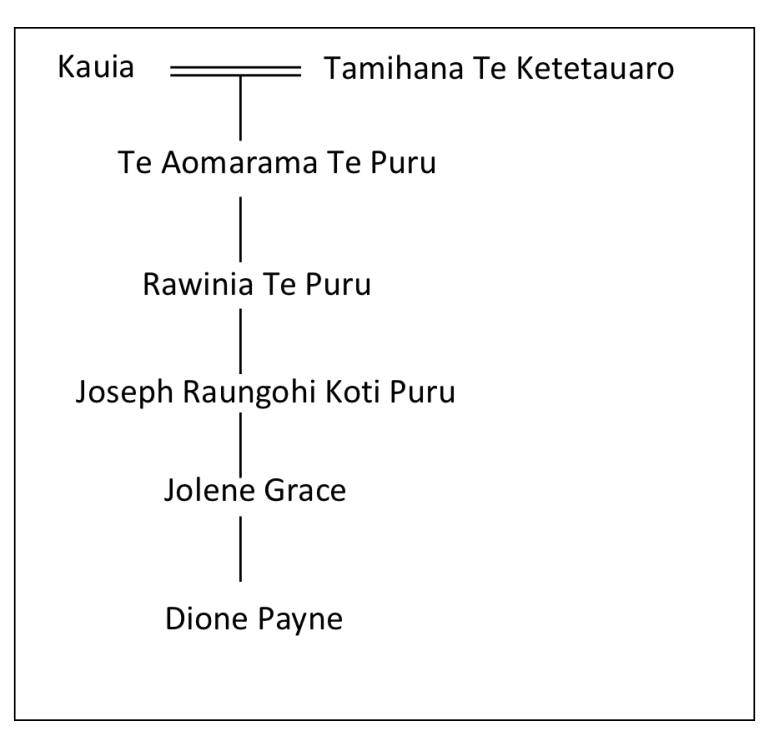
movement is the likely reason, however the end result is that little information is either published or known of the Ngāti Hine hapū, so greater reliance on Māori Land Court minute books and Archive material has been necessary. Information gleaned from whānau and hapū members has been triangulated with government records and those records utilised as references for this thesis. This does not devalue the oral information obtained but

\footnotetext{
${ }^{10}$ See Michael King, Te Puea: A Biography, 1st Ed, Auckland, Hodder and Stoughton, 1977, p.149

${ }^{11}$ Judge McCormick's report to the Chief Judge of 5 January 1926 refers to Wilkinson's report filed on “Office File 91/1494” in 'Whangamarino Decision', Mercer Minute Book, Volume 24, 27 August 1927. Searches at Archives New Zealand and the Maori Land Court have been unsuccessful.
} 
rather, allows government records to support the kōrero provided.

Lastly, two interviews were conducted during this research, which some may see as too few but these two established and confirmed key information contained in Wilkinson's reports and Māori Land Court records. More interviews may have been useful however it was decided that using kōrero of adults who were living on the block during the 1940s and 1950s rather than those who were children at the time. Interviews then, were limited to those surviving adults who lived on the block during that time

\section{My background}

Te Ao Mārama Tamihana is one of the original grantees in Lot 512. Her mother, Kauia Tamehana (or Kauia Kauia), had take tūpuna to the block while her father, Tamehana Te Ketetauaro, is of Ngāti Mahuta descent. Te Ao Mārama lived and occupied the block until her death in 1958. She had 13 children and a number of whāngai children, one of which was my grandfather, Raungohi Koti Puru, who was her grandson through her fifth child, Rawinia. Raungohi was born and raised at Okarea with Te Ao Mārama and her husband, Puru Te Tahua, and as an adult returned there following his marriage to Ngawini Toka Powell of Ngāti Whatua, Te Aupouri and Ngāti Apa descent.

In 2010, following a decision to finish the marae buildings at Okarea marae, I was given the task of researching the land block where the marae was situated. The Hamilton office of the Māori Land Court held succession information to the original owners but there was little information found to point to the block's history. A visit to the Auckland office of Archives New Zealand however, provided a broader history of the block including information on the sale of Lots 512E and F.

It was during this process that it became clear how the blocks were partitioned, sold and leased. Upon finding the Māori Land Court minutes on the block file at Archives, it became evident that Lots $512 \mathrm{E}$ and $\mathrm{F}$ had been sold in the national interests without being clear on what national interest means or the origin of the criteria used in the block's alienation. After further investigation and research, I decided to utilise this information as a thesis for PhD study. 
Alienation within the context of this thesis includes the taking of Māori land by sale and lease. Legislatively, as can be seen in Te Ture Whenua Māori Act 1993 (as outlined in more detail in Chapter Six), alienation also includes, inter alia, the granting of licences, easements, mortgages, charges or encumbrances, trusts over or in respect of Māori land, land taken under the Public Works Act 1981 or by the Māori Trustee or any other Trustee and succcession. ${ }^{12}$ Land taken in the twentieth century through the Native and Māori Land Court is commonly referred to as alienation, even where that alienation is forcibly undertaken.

This thesis looks closely at the use of the term alienation in the taking of Māori land in comparison to the practices of nineteenth century confiscation. I argue that facilitated alienation of Lot 512 from its Māori owners in the 1960s mirrors the practice of confiscation, which is often considered a historical practice. In doing so, I also argue that continuing to label the forcible taking of Māori land as alienation diminishes the impact it had on whānau and hapū, particularly in the Waikato. My argument is that Lot 512 was confiscated, not just alienated, and this thesis provides the background and history of Lot 512 to prove that point.

As a descendant of Te Ao Mārama, this thesis has significant cultural relevance for her descendants. Academically, this thesis is also an historical account of a land block returned to Waikato Māori following the invasion of Waikato in the 1860 s, set aside for rebel Māori in the 1880 s, granted to those eligible and then systematically alienated again 100 years later. This thesis is significant for my hapu as it outlines the systematic and enduring colonisation and confiscation of land that continued in the Waikato through to the 1960 s.

This thesis will investigate the various agents of alienation of Māori land and the use of national interest as a rationale for alienating Lot 512. The underlying theme of my thesis focuses on land productivity as an enduring policy that has been utilised to alienate Māori land in the 1860s as well as the 1960s, when Lot 512 was confiscated.

\footnotetext{
12 Section 4(a), Te Ture Whenua Maori Act 1993.
} 


\section{Discipline}

This thesis focuses on Ngāti Hine at Pōkaewhenua, which is situated on Lot 512. This thesis falls predominantly within the Māori Studies discipline given the perspective from which this thesis is articulated, is a whānau perspective, from an insider's point of view. This thesis weaves within it, the voices of generations upon generations whose history and lived experience has been ignored. Although the study of Lot 512 is historical in nature and involves research into the confiscation of the Parish of Whangamarino and Lot 512, compensation and then further alienation 100 years later, the manner by which these activities are undertaken takes into consideration the impact this has on the whānau from a whānau perspective. This perspective is personal, not objective and as weill be seen in the methodology chapter takes as its foundation a Waikato approach, utilised a Waikato methodological framework called Te Whare Tongikura.

By necessity and as part of my methodology, the study of colonial and settler development, early land law pertaining to Māori land and contrasting the practice of confiscation in the 1860s and the 1960s acknowledges the discipline of historiography but the lack of objectivity and framing from an insider's view, locates this research in Māori Studies.

Māori studies is a "cultural system of knowledge about everything that is important in the lives of the [Māori] people". ${ }^{13}$ It includes the study by Māori, of areas of interest to Māori, ranging from social, cultural, educational, political, theoretical, religious, science and the arts, to name a few. It reinforces our identity as Māori as well as places an importance on history, knowledge, language, how Māori think and allows for both traditional and contemporary knowledge..$^{14}$

Importantly however, Māori studies diverges markedly from western academic knowledge which Ranginui Walker argues utilises conceptually inadequate tools,

\footnotetext{
${ }^{13}$ Hirini Moko Mead, 'Understanding Matauranga Maori', in Nga Kaituhono, ed., Conversations on Matauranga Māori, Wellington, New Zealand Qualifications Authourity, 2012, p.13.

${ }^{14}$ Ibid.
} 
"defective research models and moncultural myopia". ${ }^{15}$ In essence, it is the study of Māori from a Māori point of view. Eddie Durie argues that Māori Studies is

a history of colonisation, subjection to cultural imperialism and a protracted struggle for cultural survival and emancipation against the powerful forces of the nation-state, the political economy and the ideology of assimilation. ${ }^{16}$

Māori Studies, much like Indigenous studies, focuses on the interrelatedness amongst kinship groups and the environment and have a set of values that are intrinsic to their cultural outlook, while placing themselves in the centre. Jeff Corntassel, in writing about his own research experience stated that he is

Tsalagi first and a trained political scientist second. I want my life to reflect my attempt to walk the way of the wi-gaduwaga based on relations to kinfolk, homelands/holy places, histories, language and ceremonial life. ${ }^{17}$

Corntassel also argues however, that as Tsalagi his idea of the world is not representative of all Native Americans and that he can only represent himself when discussing his ideas of indigeneity. ${ }^{18}$ This is an important point. Māori studies and Indigenous studies are unapologetic about their beginning and end points and the structure of this thesis is similarly placed. As an example, at the beginning of each chapter, regardless of its content, the Ngāti Hine story is placed at the front, giving context to what is happening to the whānau, hapu and iwi at that given time and space. As was mentioned earlier, the methodology throughout this thesis will be founded on Ngā Tongikura o Tāwhiao and the multiplicity of strands of thought to bring this story together. It does not follow a strictly western application of an academic study, more so because whānau and hapū are not static, but rely on the many strands required to retell the history of Lot 512, placing the whānau and hapū at the centre and the events in the periphery.

\footnotetext{
${ }^{15}$ Ranginui Walker, 'A consumer view on research', Paper delivered to the Ministerial Conference on Educational Research, 19 April 1978, p.10.

${ }^{16}$ Ranginui Walker in M. Reilly, 'Māori Studies, past and present: A Review', The Contemporary Pacific, 23, 2, 2011 , p.354.

${ }^{17}$ Jeff Corntassel, 'An activist posing as an academic', American Indian Quarterly, 27, 1/2, 2003a, p.161

18 Ibid.
} 
The following chapter will explain further the methodology and structure of this thesis and outline the key concepts underpinning this research. 


\section{CHAPTER TWO: TE WHARE TONGIKURA}

Māku anō e hanga i tōku nei whare. Ko nga pou ō roto he mahoe, he patatē.

Ko te tāhuhu, he hīnau. Me whakatupu ki te hua o te rengarenga

Me whakapakari ki te hua o te kawariki. ${ }^{19}$

I shall fashion my own house. The support posts shall be of māhoe and patatē. The ridge-pole is of hīnau. The inhabitants shall be raised on rengarenga and nurtured on kawariki.

Pōtatau was elected in 1858 at Pukawa during a period of widespread economic expansion of Waikato Māori in the 1830 s to 1850 s. $^{20}$ Tāwhiao, the second Māori King, reigned from 1860 to 1894 following the death of his father, Pōtatau Te Wherowhero, on 25 June 1860. Tāwhiao was 38 years of age when he was crowned King and by 1860, Waikato's economic success had engendered a pervasive desire by settlers to access Māori land for their own development. ${ }^{21}$

Tāwhiao had observed settlers' imminent land hunger and although he had a previous friendship with Governor Grey during his first term as Governor General, Grey's departure to the Cape Colony in 1854 meant that on his return in 1861 the relationship had weakened. Grey's mandate to alienate Māori land for colonial settlement clashed with the Kingitanga's policy of stopping all land sales in the Waikato and therefore set the context within which Tāwhiao wrote his tongikura. ${ }^{22}$

This chapter sets out the methodological framework for this thesis which I have centered around Tāwhiao's tongikura. An explanation of tongikura will be outlined, including its significance and how this tongikura will be utilised as a framework for incorporating methodologies such as Māori historiography and Kaupapa Māori.

\footnotetext{
${ }^{19}$ Tāwhiao in Totorewa, 'Rights of First Refusal', p.10.

${ }^{20}$ Turongo House, Tāwhiao, p.25.

21 Ibid.

${ }^{22}$ ibid, p. 53 .
} 


\section{Tongikura}

Tongikura are prophetic sayings or aphorisms (commonly referred to as tongi) and are ordinarily associated with Tāwhiao. ${ }^{23}$ There are no translations of the word tongikura across the range of Māori dictionaries but when they are referred too, they are generally understood as messages from Tâwhiao that inspired the Waikato people to move through the challenges of the nineteenth-century. ${ }^{24}$ Tongikura are still in use today and during the Koroneihana celebrations in 2013 a list of 19 tongikura were provided to the iwi and wānanga undertaken at Maurea Marae to promote and teach these tongikura to reaffirm their importance to the iwi. The tongikura used in this chapter is commonly seen throughout Waikato today in schools, tertiary institutions and government departments.

The tongikura at the beginning of this chapter derives from the devastation arising from land confiscations in the Waikato. After the confiscations, previously available resources like the rimu, tōtara, and kahikatea trees became unavailable to Tāwhiao for the building of his whare, or those of his people. Both land and rights to resources were confiscated and in reality, Māori had to apply to the Governor for the use of trees to carve things like waka or build new whare. ${ }^{25}$

As a background to this tongikura which is often referred to as Tāwhiao's attempt to rebuild his people and nourish them, there is an aspect that promotes a methodology of utilising resources that are available for use, regardless of preference. ${ }^{26}$ Customarily, tōtara, and kahikatea and the tall, straight, and stong trees of the forest were preferred for the making of important things like whare, waka, and pātaka. These trees were also home to the numerous fruits and birds that were the staple of Māori diet in that period. With these resources now absent through confiscation, Tāwhiao turned to Te Wao nui a Tāne (the forest) to find resources that could meet his ends of providing shelter for his people.

\footnotetext{
${ }^{23}$ Brad Totorewa, Right of First Refusal, p.10.

${ }^{24}$ Dean Mahuta, 'Honouring the voice of the Ancestors etc', Te Kaharoa, 4, 2011, p.188.

${ }^{25}$ See Section 262 and 346 of the Māori Purpose Act, 1931.

${ }^{26}$ Totorewa, Right of First Refusal, p.10.
} 
The tāhuhu (backbone) of any house has to be strong in order to support the roof. Tāwhiao chose to highlight the hīnau (Elaeocarpus dentatus) tree in his tongikura as it has a shorter trunk and its ability to support a high canopy of leaves and branches is substantial. The hīnau tree also produces a hua (fruit) that when processed correctly forms the meal from which a type of bread can be made. ${ }^{27}$ Tāwhiao used this tongikura both figuratively and in the actual building of his whare given these were the main woods available to him following confiscation.

In his tongikura, the pou (pillars) in Tāwhiao's house were fashioned by mahoe and patatē. The Māhoe tree (commonly known as Whiteywood) is a common tree, whose favorite growing place is on partially cleared land, which proliferated in Waikato throughout the period following confiscation and was therefore easily accessible. Māhoe also had the advantage of being useful as a kaunoti (platform to make friction fire) when used in conjunction with a kauati (friction stick) made from the kaikomako (Pennantia corymbosa) tree. The charcoal of the māhoe can also be processed into the making of gunpowder, which in itself was useful during the war period. ${ }^{28}$

The other pou, fashioned by patate (Schefflera digitata) is a small shrub found mainly in damp areas of the forest, around stream banks and swamps, ${ }^{29}$ an environment that was also prolific in Waikato where the Waikato River is the central identity of Tāwhiao's people. While having promoted a pathway for producing shelter amongst his people, Tāwhiao gave an indication as to how the people could also nourish themselves. He pointed to the fruits of the rengarenga (Arthropodium cirratum), a small rock lily found on cliff faces and around coastal scrub which was edible ${ }^{30}$ and to the kawariki (Freycinetia baueriana ssp. Banksii) the fruit of the kiekie vines as sources of food which, when combined with the fish resources from the river and sea coast, provided for a fully sustainable diet to ensure survival. This was in response to the limited ability to cultivate crops on land that had been confiscated in Waikato. These alternative resources were so numerous that they were able to feed a great many people following confiscation.

\footnotetext{
${ }^{27}$ J.T Salmon, The Native Trees of New Zealand, Auckland, Heinemann Reed, 1980, p.176.

${ }^{28}$ Ibid, p. 118 .

${ }^{29}$ Ibid, p. 248 .

${ }^{30}$ See http://netlist.co.nz/communities/NZGardens/PlantoftheWeek.cfm?NLID=104, downloaded on 20 April 2013.
} 
Tāwhiao also left this tongikura as a philosophical methodology for the Waikato people to move forward. He suggested that although the finest trees in the forest had been taken, the kauri, the rimu and the totara, there remained trees that could still be used by his people, and plants that would nourish them. The key message suggests that even the soft trees of the forest could build a strong whare. Joe Williams argues that Tāwhiao utilised the

architecture of the traditional carved meeting-house as his metaphor, his message...was that his first task was to be the shelter in which his people could survive and heal themselves. ${ }^{31}$

Tāwhiao was so confident in his methodology, that following the battle at Rangiriri, he was known to have said:

E kore tenei whakaoranga e hui ki tua o taku mokopuna, ka puta, ka ora.

The suffering will not survive beyond the days of my grandchildren when we shall reach salvation. ${ }^{32}$

Therefore, Tāwhiao, through the tumultuous period post confiscation, was forced to adapt to a new environment in his own land. The overwhelming intent of the settler government was to remove Tāwhiao and the Kīngitanga in order to open up lands for settlement. In response, Tāwhiao fashioned a new methodology of building his own house with new resources, not previously favoured. By doing so, he effectively changed the template for his people and created a pathway of leadership that is still adhered to today. He created a methodology that fitted his circumstance and desired outcomes.

\section{He whare tongikura: A methodological framework}

The whare tongikura utilised in this thesis is a whare within which research methodologies and concepts are housed that align with key messages set out in

\footnotetext{
${ }^{31}$ Joe Williams, 'Confessions of a Native Judge: Reflections on the role of transitional justice in the transformation of indigeneity', Land, Rights, Laws: Issues on Native Title, 3, 4, 2010, p.6.

${ }^{32} \mathrm{Na}$ Tāwhiao Matutaera Te Wherowhero, see Turongo House.
} 
Tāwhiao's tongikura. Brad Totorewa, Kauhanganui member for Maurea marae, Rangiriri historian and leader in the Te Riu o Waikato region first utilised Tāwhiao's tongikura as a philosophical methodology that links directly to the Kingitanga and as a "guiding research method framework". 33 Totorewa analyses each part of the tongikura to show how it has direct relevance to his research topic and the methodologies encompassed in his study (see Table 1). ${ }^{34} \mathrm{I}$ include it here in full because I will also draw from this framework to demonstrate how I will be utilising tongikura as a methodological framework that is specific to Waikato.

Totorewa's use of the tongikura as a research methodology shows how the analogy of a whare can be utilised to build a framework around research methodologies. By attributing whakawhānaungatanga as the whare and ngā mahaki as the support posts, Totorewa then utilises te reo me ona tikanga as the backbone for his research and te angitu and koha as the outcomes for his research. This is an insightful and innovative use of Tāwhiao's tongikura and aligns with the way in which I will be using tongikura in this thesis.

For my study, the whare which encompasses my thesis is Māori historiography as my research traces the occupation and alienation of papakāinga land from 1860 to 1969. This thesis adds new knowledge to the field by examining land confiscation in two significant time periods in New Zealand's economic development. The support posts that hold up my thesis are whakapapa. Whakapapa refers to those connections between whānau and hapū at Pōkaewhenua, the connections from those people to the whenua and the wider connections to the iwi. My own whakapapa to this area was provided in the previous chapter, but the layers of whakapapa to Pōkaewhenua is also built into each chapter of this thesis.

The backbone of this whare is Kaupapa Māori. This is inherently research by Māori, for Māori and with Māori. ${ }^{35}$ The key criteria that encompass Kaupapa Māori supports my approach to ground this thesis firmly in Te Ao Māori, this can be seen in both the methodology and methods of this thesis. The ramification of this thesis is seen through

\footnotetext{
${ }^{33}$ Totorewa, Rights of First Refusal, p.42.

34 ibid.

${ }^{35}$ Linda Smith, Decolonising Methodology: Research and Indigenous Peoples, Dunedin, University of Otago Press, 1999.
} 
Table 1: Brad Totorewa Tongikura Framework

\begin{tabular}{|c|c|c|c|}
\hline Tongikura & Translation & Method & $\begin{array}{l}\text { Research } \\
\text { Relevance }\end{array}$ \\
\hline $\begin{array}{l}\text { Maaku anoo e } \\
\text { hanga } i \text { tooku nei } \\
\text { whare }\end{array}$ & $\begin{array}{l}\text { I shall fashion my } \\
\text { own house }\end{array}$ & $\begin{array}{l}\text { Whakawhānaungatanga: } \\
\text { (Building relationships) } \\
\text { The identification of } \\
\text { relevant stakeholders and } \\
\text { iwi members for } \\
\text { interviews and surveys }\end{array}$ & $\begin{array}{l}\text { The construction } \\
\text { and galvanisation } \\
\text { of iwi based } \\
\text { research, by iwi for } \\
\text { iwi }\end{array}$ \\
\hline $\begin{array}{l}\text { Ko ngaa pou oo } \\
\text { roto he Maahoe, } \\
\text { he Patete }\end{array}$ & $\begin{array}{l}\text { The support posts } \\
\text { shall be of Maahoe } \\
\text { and Patete }\end{array}$ & $\begin{array}{l}\text { Kia Ngakau mahaki: } \\
\text { (Be humble) } \\
\text { The application of core } \\
\text { values aroha, ture, } \\
\text { whakapono }\end{array}$ & $\begin{array}{l}\text { Being resolute in } \\
\text { upholding the } \\
\text { spiritual, physical } \\
\text { and intellectual } \\
\text { ways of being, as } \\
\text { Maaori researchers. }\end{array}$ \\
\hline $\begin{array}{l}\text { Ko te taahuhu, he } \\
\text { Hinau }\end{array}$ & $\begin{array}{l}\text { The ridgepole is of } \\
\text { Hinau }\end{array}$ & $\begin{array}{l}\text { Te Reo me ona Tikanga } \\
\text { (Utilisation of Te Reo } \\
\text { Maaori). The ability to } \\
\text { conduct bilingual } \\
\text { interviews and surveys }\end{array}$ & $\begin{array}{l}\text { Inclusivity, the } \\
\text { ability to } \\
\text { communicate to a } \\
\text { diverse iwi } \\
\text { demographic } \\
\text { composition. }\end{array}$ \\
\hline $\begin{array}{l}\text { Me whakatupu ki } \\
\text { te hua o te } \\
\text { Rengarenga }\end{array}$ & $\begin{array}{l}\text { The inhabitants } \\
\text { shall be raised on } \\
\text { Rengarenga }\end{array}$ & $\begin{array}{l}\text { Te Angitu } \\
\text { (Striving for success). To } \\
\text { inquire, review, reflect } \\
\text { and reconstruct past, } \\
\text { present and future } \\
\text { direction. }\end{array}$ & $\begin{array}{l}\text { The } \\
\text { implementation of } \\
\text { new insights for iwi } \\
\text { prosperity }\end{array}$ \\
\hline $\begin{array}{l}\text { Me whakapakari ki } \\
\text { te hua o te } \\
\text { Kawariki }\end{array}$ & $\begin{array}{l}\text { And nurtured on } \\
\text { Kawariki }\end{array}$ & $\begin{array}{l}\text { Koha } \\
\text { (Contributions of } \\
\text { consequence). Feedback } \\
\text { and feed forward that } \\
\text { leads to change and } \\
\text { sustainability. }\end{array}$ & $\begin{array}{l}\text { The opportunity for } \\
\text { Iwi voice to inform } \\
\text { future direction and } \\
\text { sustainable } \\
\text { solutions for the } \\
\text { Iwi. }\end{array}$ \\
\hline
\end{tabular}


the examination of colonial language as it pertained to Māori land ownership and utilisation and the impact this language had on land retention or alienation. The case study is the core of this thesis and answers the "why", "how" and "so what" of the case study. I was tasked by my whānau to find out what happened, why it happened and what can we do about it.

The rengarenga and kawariki of this thesis seeks to answer those questions, both in the analysis of information and the feedback to the whānau and hapū. It is through this whare tongikura that the structure of this chapter and articulation of my methodology will be set out.

\section{Māku anō e hanga i tōku nei whare: Māori historiography}

For the context of this thesis, the whare this research is located in is Māori historiography. Historiography in New Zealand has been predominantly focused on a history replete with Pākehā writings and Pākehā perceptions of Māori culture. New Zealand and Waikato history written by Pākehā paints a history of rural and urban development, productive land utilization based on scientific farming and a reliance on agricultural interdependence with export earnings. ${ }^{36}$ The focus is often on the Crown and settlers with little attention on confiscation, relocation and poverty of the Waikato Māori who previously owned the land. Instead, the focus is often on the framing of settler history and development through a "white" telling of the Waikato story.

\footnotetext{
${ }^{36}$ Michael King, The Penguin History of New Zealand, Auckland, Penguin Books, 2003, p.238; Department of Agriculture and Fisheries, Farming in the Waikato, Hamilton, Department of Agriculture and Fisheries, 1974, p.24 and New Zealand Agriculture: Waikato Agriculture - Farming Systems, Wellington, Department of Agiculture, 2000a, p.1 and New Zealand Agriculture: Waikato Agriculture - A Regional Introduction, Wellington, Department of Agriculture, 2000b, p.1; C. E. Wheeler, Dairy Farming in New Zealand, Wellington, Harry H Tombs Ltd, 1921a, p.9 and New Zealand: The Country, its people and resources, Auckland, Brett Printing and Publishing Company Ltd, 1921b, p.41; Department of Agriculture Farming in New Zealand, Wellington, Hutcheson, Bowman and Stewart Ltd, 1950, p.202; See 'Address in Reply' in NZPD, Volume 297, 1 July 1952, pp.52-55, 'Want of Confidence', 3 July 1952, p.1505 and Ernest Corbett, 'Land Settlement Promotion Bill', NZPD, 4 September 1952, p.1298; Horace Belshaw, 'Dairying Industry in New Zealand', Economic Geography, 2, $3,1927$.
} 
The generic history of New Zealand and proliferation of observationist writers in the 1800 s relegated Māori to something different, less, strange, barbaric or savage. ${ }^{37}$ Edward Said argues that

the Eurocentric culture relentlessly codified and observed everything about the non-European or presumably peripheral world, in so thorough and detailed a manner as to leave no item untouched, no culture unstudied, no people and land unclaimed. ${ }^{38}$

This other-ing reduced Māori to objects of research and when retold in New Zealand history, often misrepresented or misconstrued Māori knowledge and history. This is not unusual for research from a positivist paradigm that encouraged scientific objective methods of research ${ }^{39}$ giving researchers the right to study, extract and write about people and their knowledge for their own benefit. ${ }^{40}$ Positivist research has minimized and misrepresented Māori knowledge by "simplifying, conglomerating and commodifying Māori knowledge for "consumption" by the colonisers". ${ }^{41}$

Furthermore, the writing of tribal or hapū history is not ordinarily accepted or acknowledged as valid interpretations of history, ${ }^{42}$ particularly given history is often seen through a western lens and "judged in European contexts" ${ }^{43}$ leaving Māori struggling to have their work validated. ${ }^{44}$ Historians such as Aroha Harris, Danny

\footnotetext{
${ }^{37}$ See Keith Sinclair, The Origins of the Māori Wars, Wellington, New Zealand University Press, 1957, pp.6-8; F.A Carrington, Letter to Governor Gore Brown, AJHR, Session I, E-No.3e, 21 March 1859, p.2; Gore Browne, Letter to Duke of Newcastle, AJHR, Session I, E-No6a, 20 September 1859, p.3.

${ }^{38}$ Edward Said 'Yeats and Decolonisation' in Seamus Deane, ed., Nationalism, Colonialism and Literature, Minneapolis, University of Minnesota Press, 1990, p.72.

${ }^{39}$ Suzanne Pitama, "'As natural as learning pathology': The design, implementation and impact of Indigenous health curricula within medical schools', PhD Thesis, University of Otago, 2013, p.65.

${ }^{40}$ Fiona Cram, 'Rangahau Māori: Tona tika, tona pono - the validity and integrity of Māori research' in M Tolich, ed., Research Ethics in Aotearoa New Zealand: concepts, practices, critique, Auckland, Longman, Auckland, 2001.

${ }^{41}$ Russell Bishop 'Freeing ourselves from neo-colonial domination in research: A Māori approach to creating knowledge' International Journal of Qualitative Studies in Educational, 11, 2, 1998, p.200.

${ }^{42}$ Smith, Decolonising, pp.34-5.

${ }^{43}$ Eddie Durie, 'Ethics and Values in Maori Research', He Kupenga Korero: A Journal of Maori Studies, $4,1,1998$, p.62.

${ }^{44}$ Linda Smith, Decolonising, p.55; Joe Pere, 'Hitori Māori' in C Davis and P Lineham, eds., The Future of the Past: Themes in New Zealand History, Palmerston North, Massey University Press, 1991, p.29 and pp.35-36; Tipene O'Regan, 'Old Myths and New Politics: Some contemporary uses of traditional history', in Judith Binney, ed., The Shaping of History: Essays from the New Zealand Journal of History, Wellington, Bridget Williams Books, 2001, p.20; Michael Belgrave, 'The Tribunal and the past: Taking a roundabout path to a new history' in Michael Belgrave, ed., Waitangi Revisited: Perspectives on the
} 
Keenan, Joe Pere, and Nepia Mahuika have written back, contesting the space for New Zealand history. Aroha Harris argues that

Māori historians are involved more and more in writing histories that help Māori escape the past into which they have found themselves written; the dominant historical discourse, which tends to locate Māori in the context of British colonialism and expansionism. ${ }^{45}$

For Harris, Māori contributions to their own history have taken on an iwi centric view and although Māori history is unable to escape from New Zealand's colonial past, their starting point from within the centre of their iwi, history as seen from their own space, allows Māori historians to add to and redefine New Zealand's past. ${ }^{46}$ Danny Keenan argues that Māori historical scholarship should involve writing about your own area and utilizing processes and frameworks that

operate within traditional boundaries and frameworks, set by tribal imperatives, the sheer extent of which cannot be easily appreciated by 'outsiders'. 47

Nepia Mahuika warns that even this insider perspective centres colonial institutions. Mahuika argues that

in many ways this seems ironic for a theory that considered writing back to the centre as an empowering act yet forgot that the centre itself was the problem. $^{48}$

For this PhD, I am predisposed to research for the benefit of the community, not to "write back" in binary opposition to what has been written. Writing back focuses on

Treaty of Waitangi, Auckland, Oxford Unity Press, 2002, p.122; Edward Said, Culture and Imperialism, New York, Alfred A. Knopf, 1993, pp.xii-xiii.

${ }^{45}$ Aroha Harris, 'Dancing with the state: Māori creative energy and policies of integration: 1945-1967', PhD Thesis, University of Auckland, 2007, pp.24-25.

${ }^{46}$ Harris, 'Dancing with the state', p. 25.

${ }^{47}$ Danny Keenan, 'Predicting the Past: Some directions in recent Māori historiography', Te Pouhere Körero, 1, 1, 1999, pp.31.

${ }^{48}$ Nepia Mahuika, 'Closing the gaps: From postcolonialism to Kaupapa Māori and beyond', New Zealand Journal of History, 45, 1, 2011, p.12. 
history that is rewritten from an Indigenous view point either back to the colonial centre, academia, other colonized peoples or themselves. Linda Smith argues that writers such as Ngugi wa Thiong'o, Cherryl Smith and Leonie Pihama promote writing from the Indigenous perspective, utilizing Indigenous language and concepts which places Indigenous people at the centre of history. ${ }^{49}$

Although the investigation of Lot 512 includes a focus on colonisation, its processes and government department interaction, having an insider's view allows a standpoint where the central pou of this research remains in Lot 512 and the main purpose of the discussion is not lost amongst a colonial narrative that nonetheless, has a large part to play in Lot 512's history. However to write effectively from an insider perspective, the whānau and hapū are at the centre of this research. When writing from a Māori, or iwi perspective, the use of whakapapa is a central concept.

\section{Ko ngā pou o roto: Whakapapa}

The support posts within my whare are lashed together by whakapapa. It is vital for my thesis that the use of Māori historiography utilize whakapapa to support its location given the telling of tribal history focuses on relatedness to people, land and location. The use of whakapapa here refers to both whānau, hapū, iwi and whenua relationships as well as explaining experiential history of specific agencies, connections and values. Experiential history for the context of this thesis refers to the experiences landowners and their descendants had with a range of government agencies and the differing values each party had. Aroha Harris refers to a similar concept as the "whakapapa of experience" which locates Harris within her research showing her connectivity through "blood and bone" and the urbanization experience of her parents and leadership of her grandparents. ${ }^{50}$

For most Māori, whakapapa is the basis upon which kinship and whenua relationships are based. On introducing themselves, many Māori will give their pepeha explaining their relationship to either their maunga, awa, moana, hapū, iwi, whānau, waka, and/or tūpuna. They will relate this information to themselves to explain who they are and where they are from. These pepeha are not always presented in the same way but

\footnotetext{
${ }^{49}$ Linda Smith, Decolonising, pp.35-7.

${ }^{50}$ Harris, 'Dancing with the state', pp.25-26.
} 
depend upon circumstances. Particular sets of connections may be required in one place while in another place a different connection will be made between the speaker and the people they are meeting. My connectivity to Lot 512 and Okarea is specifically outlined in the following pepeha:

\section{Ko Pukekamaka tōku maunga \\ Ko Pōkaewhenua tōku papakāinga \\ Ko Pōkaewhenua tōku awa \\ Ko Ngāti Hine ki Waikato tōku hapū \\ Ko Te Ao Mārama tōku tūpuna}

Māori society functions on the connections between whānau, hapū, iwi, waka, whenua, eponymous ancestors, marae, mountains or waterways (be they ocean, rivers, lakes or streams). Similarly, the telling of a historical event, in a Māori context will usually involve a place and a person or people that are linked by whakapapa.

Joe Pere argues that

writers of tribal history should be those who have kinship connections through whakapapa to the particular tribe and that access to that information should have the approval of the elders. ${ }^{51}$

Wally Penitito also argues that whakapapa is what makes Māori unique, ${ }^{52}$ and in the context of this thesis, whakapapa is what makes Māori historiography unique. There is an ability in this thesis to whakapapa the writer to Lot 512, from Lot 512 and its hapu members to each other and to the Waikato iwi, onwards to those members also at Rangiriri, Ōrākau, Hingakākā and other significant Waikato events. All these people and places have a connection to Waikato that allows the writer to write within a cultural understanding of how those people and places are connected.

\footnotetext{
51 Joe Pere, 'Hitori Māori', p.45.

${ }^{52}$ Wally Penetito, 'Kaupapa Māori education: Research as the exposed edge', in 'Kei Tua o Te Pai hui Proceedings: The challenges of Kaupapa Māori research in the $21^{\text {st }}$ Century', Wellington, Pipitea Marae, 5-6 May, 2011, p.41.
} 
The whakapapa connection between people and their marae continues to be vitally important for many Māori. Marae are ordinarily named after an ancestor, on land that has either take tūpuna, take raupatu or take noho. Using whakapapa within my whare tongikura makes the connectivity between myself and the case study of this thesis an important factor.

Focusing my thesis on Ngāti Hine allows me to research an area that I have whakapapa links to and also where I have an on-going relationship with my marae, whānau and hapū. For my study this is important. It is unlikely that an outsider would easily understand the dynamics of the hapu's history in Lot 512, let alone be able to access the history of whānau occupation on the block. This whānau history puts into context the literature and archival resources, as well as the whakapapa connections and interrelationships with other hapū in Waikato and Hauraki given the alienation of Lot 512 had a direct impact on my whānau while they were still occupying the block until 1969 when they were evicted as a result of that alienation.

This thesis also contributes to the tribal history of Waikato by providing an account of Ngāti Hine ki Pōkaewhenua. This history has not been written about previously, and this $\mathrm{PhD}$ provides an opportunity to contextualize the impact of colonisation and confiscation in Pōkaewhenua as experienced by Ngāti Hine.

It is for this reason that each chapter begins with tongikura and an explanation of its connection to the main theme in the chapter. References to Waikato or Pōkaewhenua are utilised wherever possible to maintain Ngāti Hine at the centre of this thesis.

\section{Ko te tāhuhu, he Hīnau: Kaupapa Māori}

The ridgepole that acts as the backbone of this thesis is Kaupapa Māori methodology. Kaupapa Māori encompasses the core values that underpin this thesis and emerged in the 1990s as a tool to validate Māori knowledge and contribute to a wider Indigenous agenda that validated Indigenous research methodologies. ${ }^{53}$

\footnotetext{
${ }^{53}$ Smith, Decolonising, pp.117-119.
} 
Kaupapa Māori provides key criteria that has evolved since its initial articulation and included such definitions as research by Māori, for Māori and according to Māori values. $^{54}$

Linda Smith set out a list of seven cultural values ${ }^{55}$ that are often used as the basic context by which Māori research should be conducted. These criteria are briefly outlined below.

Aroha ki te tangata requires that researchers respect those they are researching, and that research actually benefits research participants. Smith argues that the benefits to the community is vital and that cultural rules of engagement and feedback be addressed prior to working with communities. ${ }^{56}$

He kanohi kitea is often expressed as kanohi ki te kanohi or a kanohi which is the ability to see one's face, to greet one's ancestors and can allow research participants to dictate their space and the kawa and rules of engagement. ${ }^{57}$

Titiro, whakarongo...kovrero follows sequentially from the prior two above. Many Māori researchers are encouraged under this criteria to look and listen before they speak or seek to convey, reinterpret or feedback information. It acknowledges that the research participants are more knowledgeable in the subject area, and that the knowledge should be respected, valued and earned. Coupled with humility, it also ensures that researchers will not "barge in like the expert and to ensure there is mutual respect". 58

Manaaki ki te tangata is expressed in a number of ways, whether by koha, kai, exchange of ideas and information or ensuring a power balance that acknowledges and cares for the research participants. It acknowledges that it is your time to learn from

\footnotetext{
${ }^{54}$ Linda Mead, 'Nga aho o te kakahu matauranga : the multiple layers of struggle by Maori in education', PhD Thesis in Education, University of Auckland, 1996.

${ }^{55}$ Cram, 'Rangahau', 2001 and Kathie Irwin, 'Maori Research Methods and Practices', Sites, 28, Autumn, 1994, pp.25-43

${ }^{56}$ Smith, Decolonising, p.15.

${ }^{57}$ Cram, 'Rangahau', p.44.

${ }^{58}$ Wheturangi Walsh-Tapiata, 'Research within your own iwi - What are some of the issues?', 'Proceedings of Te Oru Rangahau', Paper delivered to Te Oru Rangahau Māori Research and Development Conference, 7-9 July, Massey University, 1998, p.254.
} 
your community and ensuring the "researched" have your trust and will be treated with the utmost respect. ${ }^{59}$

Kia tüpato articulates the responsibility of the insider's research as being humble as a member of the community who also undertakes the responsibility and position of the researcher. ${ }^{60}$ This requires researchers to move between multiple positions, removing rose-coloured glasses and looking at information objectively. ${ }^{61}$ Tūpato also requires cultural safety where tikanga Māori is upheld during hui and an ability to navigate whānau politics and ensure kōrero is not manipulated towards pre-determined ends. ${ }^{\mathbf{6 2}}$

Kaua e takahia te mana o te tangata seeks to ensure that extractive, one-way research which seeks to benefit the researcher and not the community is avoided. ${ }^{63}$ Smith uses a set of questions ${ }^{64}$ for the researcher to reflect on the purpose of their study and to consider who benefits from the study and how negative outcomes can be managed so that reflective and respectful research methods and processes are undertaken. ${ }^{65}$

Kaua e mahaki focuses on maintaining humility through the acquisition of knowledge and that although knowledge is gained this does not necessarily make the researcher more knowledgeable.

\section{An evolving methodology}

More recently however, Kaupapa Māori has evolved to encompass the varying ways Māori researchers utilize their own tikanga to carry out their research, within a broad Māori world view. As the Keynote Speaker at the Kei Tua o te Pae Hui in 2011, Linda Smith argued that Kaupapa Māori research is

a plan; it's a programme; it's an approach; it's a way of being; it's a way of knowing; it's a way of seeing; it's a way of making meaning; it's a way of being Māori; it's a way of thinking; it's a thought process; it's a practice; it's

\footnotetext{
${ }^{59}$ Cram, 'Rangahau', p.45

${ }^{60}$ Smith, Decolonising, p.139.

${ }^{61}$ Ibid.

${ }^{62}$ Adam Gaudry, 'Insurgent Research,' Wicazo Sa Review, 26, 1, 2011, p.114.

${ }^{63}$ Gaudry, 'Insurgent', p.116.

${ }^{64}$ Smith, Decolonising, p.173.

${ }^{65}$ Cram, 'Rangahau', p.48.
} 
a set of things you want to do. It is a kaupapa and that's why I think it is bigger than a methodology. ${ }^{66}$

Leonie Pihama also argues that notions of a homogeneous Kaupapa Māori methodology eliminates "multiplicity of expression” particularly given Kaupapa Māori methodology has been a part of Māori society for generations and was part of the knowledge systems that were practiced by tūpuna. ${ }^{67}$

As a local thesis project, this delineation settles an underlying concern I had for utilizing a Kaupapa Māori methodology, which initially appeared nationalistic and overly prescriptive in its outlook. Pihama, Smith and Somerville's assertions that a universalized idea of Māori knowledge potentially marginalizes whānau, hapū and iwi knowledge and adds impetus to a localized whānau and hapū approach to Kaupapa Māori.

I am advocating a hapū approach within a Māori methodology that leans heavily on whānau historiography, triangulated with archival, minute book and literature sources. Similar approaches have been undertaken by Māori scholars such as Linda Smith, Danny Keenan, Wally Penitito, Alice Somerville and Leonie Pihama. ${ }^{68}$ Generalizing Māori experiences is potentially unhelpful as Māori are not homogenous, nor are hapū, and the dynamics of whānau can be less so. Professor Wally Penetito argues that

it is a fallacy to research Māori as though they are a homogenous entity. ${ }^{69}$

Penetito argues further that it is the way in which we are Māori that is important and that the heart of the Māori world is whānau. Whānau is

\footnotetext{
${ }^{66}$ Linda Smith, 'Opening Keynote: Story-ing the Development of Kaupapa Māori - A Review of sorts', Kei Tua o te Pae: The Challenges of Kaupapa Māori Research in the $21^{\text {st }}$ Century, Wellington, New Zealand Council for Educational Research, Pipitea Marae, Wellington, 5-6 May 2011, p.10.

${ }^{67}$ Leonie Pihama, 'Tihei Mauri Ora: Honouring Our Voices. Mana Wahine as a Kaupapa Maori Theoretical Framework'. PhD Thesis, University of Auckland 2001, p.25 and p.40.

${ }^{68}$ 1999, 1999, 2011, 2001 respectively.

${ }^{69}$ Penitito, 'Kaupapa Māori Education', p.38. See also S. Webster, 'Maori Hapu as a Whole Way of Struggle: 1840s-50s before the Land Wars', Oceania, 69, 1, 1998 and Pihama, 'Tihei Mauri Ora', 2001.
} 
what motivates them, that is what gets them up in the morning, that is what makes them go to the hui that is what makes them take money out of their pockets. $^{70}$

This thesis is whānau centered within a specific hapū location. This thesis does not seek to draw comparisons with other hapū or iwi who did not have a comparable experience to Ngāti Hine. This may be a limitation of this thesis. However, legislation and policy had a national application particularly in the 1960s, which will be covered in Chapter Five.

\section{Me whakatupu ki te hua o te Rengarenga: Ahuwhenua}

A central theme that runs through and gives sustenance to the argument of this thesis is the terminology utilized to convey what is acceptable. Some of the key questions this thesis seeks to answer are "what is the national interest?", "what is productivity?" and "who does it benefit?". This requires an analysis of language and intent particularly in the context of colonisation as it applied to Māori. Bruce Buchan, an Australian historian, explores the way in which language framed government policies and the techniques that were adopted in Australia. For Buchan, the way in which language defined or described

formed part of a wider discourse in which moral and political claims about [Australian colonisers] and others were advanced. In this sense, colonial 'descriptions' of Indigenous peoples as 'savages' with no 'society' or a limited 'government' also operated as a foundation for advancing claims about how they should be treated in the new colonial order. ${ }^{71}$

Buchan argues that Indigenous people have had to fight against a machinery of state that used a language, which denigrated Indigenous identity. Much like Said, who argued that the Oriental other was constructed from a western consciousness, ${ }^{72}$ Buchan's focus

\footnotetext{
${ }^{70}$ Pentito, 'Kaupapa Māori Education', p.40.

${ }^{71}$ Bruce Buchan, The Empire of Political Thought: Indigenous Australians and the Language of Colonial Government, London, Pickering and Chatto Publishers Ltd, 2008, p.2.

${ }^{72}$ Edward Said, Orientalism, New York, Vintage Books, 1979, p.8.
} 
on the language of colonisation also highlights how Indigenous people were othered and discriminated against. ${ }^{73}$

The ability for Indigenous peoples to claim and name their processes of development and identity, conducive to their own interests is stymied by colonial ideas that have been ingrained within the language of colonisation. Previous research by Joe Williams, Richard Boast, Bryan Gilling, Richard Hill, J R Holmes, and Paul McHugh have tended to focus more on the process, cause and effect of Māori land alienation. ${ }^{74}$ More research however needs to focus on the language which preceded those processes, causes and effects. By analysing the language used by New Zealand's colonial government, commonly used terms such as productivity, utilization, waste, national interest/public good/public interest/national good, highlight the fact that Māori ideas of productivity and utilization were included where it suited colonial or settler development. In the main however, for the purposes of this thesis, productivity was loaded with colonial understandings of land use.

Māori ideas of productivity, communal ownership and resource distribution was viewed negatively by settlers, the Crown and the Māori Land Court. ${ }^{75}$ Although Māori were included in the development of land, the manner in which they were included depended on the needs of the colonial and regional government. As will be seen in this thesis, Māori use of land in Māori ways was often discouraged and in the Waikato, this was particularly so. This directly impacted Māori land ownership in the Waikato, which is the key focus of this thesis.

This analysis of the language of colonisation also extends to the way in which government practices are often subjective and invariably encompass standards of conduct, which can be judged and used as rational exemplars for the general populace. ${ }^{76}$ Mitchell Dean argues that

\footnotetext{
${ }^{73}$ Bruce Buchan, The Empire of Political Thought: Indigenous Australians and the Language of Colonial Government, London, Pickering and Chatto Publishers Ltd, 2008, p.2.

${ }^{74}$ See Bibliography for full list of articles, books or book sections relating to these authors.

${ }^{75}$ See Chapter Three.

${ }^{76}$ Mitchell Dean, Governmentality: Power and Rule in Modern Society, London, Sage Publications, 1999, p.10.
} 
Rationality is simply any form of thinking, which strives to be relatively clear, systematic and explicit about aspects of 'external' or 'internal' existence, about how things are or how they ought to be. ${ }^{77}$

For Dean, it was the agents of government (or in the context of this thesis, those who I describe as the agents of alienation) whose responsibility it was to ensure individuals and groups complied with regulations and codes within the confines of what was considered normal. Linda Smith also refers to codes and regulations but articulates this as systems of classification and representation. For Smith, these classifications or codes were time and space oriented. The more "modern" society of the West was in binary opposition to the "primitive" Māori society and therefore put them at odds with the new colonial order. ${ }^{78}$ By rationalizing what was normal, colonial and settler governments separated themselves from Indigenous people ${ }^{79}$ and determined the language and terminology that secured their position in society and their economic pathway forward.

In New Zealand, colonial ideas of land ownership and use were based on the Lockean theory of productivity. This productivity was based on John Locke's seventeenthcentury theory of property rights, which conceived of land ownership determined by improvements individuals made to the land.

John Locke had a significant influence on the ideology behind colonisation by helping to provide the rationale for transplanting European settlers in colonies, with a key focus on British superiority over Indigenous people. ${ }^{80}$ The primary focus for Locke's justification for British and settler superiority and therefore necessary governorship over Indigenous peoples and their lands, was on the "grounds that the Indigenous inhabitants did not make proper use of their lands". 81

Locke's idea of a right of property, argues that:

\footnotetext{
${ }^{77}$ Ibid, p.11.

${ }^{78}$ Smith, Decolonising, p.55.

${ }^{79}$ Ibid.

${ }^{80}$ Bruce Buchan, 'The empire of political thought: civilisation, savagery and perceptions of Indigenous government', History of Human Sciences, 18, 2, 2005 b, p.4.

${ }^{81}$ Buchan, 'Indigenous government', p.4.
} 
From all which it is evident, that though the things of nature are given in common, yet man, by being master of himself, and proprietor of his own person, and the actions or labour of it, had still in himself the great foundation of property; and that, which made up the great part of what he applied to the support or comfort of his being, when invention and arts had improved the conveniences of life, was perfectly his own, and did not belong in common to others. Thus labour, in the beginning, gave a right of property, wherever any one was pleased to employ it upon what was common [emphasis added]. ${ }^{82}$

Locke considered land to be in "common" usage until man laboured to make it productive and that labour, he argued, is what gave the individual an exclusive right to the property. Locke argues that

Whatsoever then he removes out of the state that nature hath provided, and left it in, he hath mixed his labour with, and joined to it something that is his own, and thereby makes it his property. ${ }^{83}$

This removal from the "common" by productive use set in motion the norm that unutilized or unproductive land could be converted to private property by individuals who applied their labour to it. It implicitly defined then, that unproductive land was wasteful. Buchan argues this same point by noting that British civilization through colonisation encompassed property rights that were exported to "untamed wastes previously inhabited only by "wandering savages". ${ }^{84}$ Buchan goes on to argue that the labelling of Indigenous as 'savage' was not just about colonisers describing Indigenous in contrast to themselves but also linguistically and conceptually describing Indigenous as a class of people who could be dispossessed of their lands. ${ }^{85}$

Locke had effectively given a negative connotation to communally owned land as land owned in common implied that it was laying in waste or unproductive. Although an

\footnotetext{
${ }^{82}$ John Locke, Second Treatise of Civil Government, as downloaded on 4 October 2013 at: http://oll.libertyfund.org/index.php?option=com staticxt\&staticfile=show.php $\% 3$ Ftitle $=222 \&$ layout $=$ html \#chapter 16269, Chapter V, Sections 44-45, 1690.

${ }^{83}$ Locke, Second Treatise, Chapter V, Section 27.

${ }^{84}$ Buchan, 'Subjects of Benevolence', p. 37.

${ }^{85}$ Buchan, 'Indigenous government', p.3.
} 
individual who laboured on the land could privatise waste land, there were however rules set down by Locke, which insisted that land be continually utilized. Locke saw no value in produce going to rot or idleness on the land. Where this became evident, Locke considered that land to be waste land and was open for possession by an individual better able to utilize it. This had significant ramifications in the Waikato in both the nineteenth and twentieth centuries given the premise for confiscation in the 1860 s included a colonial perspective of waste land and in the 1960s, waste land was used as a rationale for selling Lots $512 \mathrm{E}$ and F. Locke argued that

The same measures governed the possession of land too: whatsoever he tilled and reaped, laid up and made use of, before it spoiled, that was his peculiar right; whatsoever he enclosed, and could feed, and make use of, the cattle and product was also his. But if either the grass of his inclosure [sic] rotted on the ground, or the fruit of his planting perished without gathering, and laying up, this part of the earth, notwithstanding his inclosure [sic], was still to be looked on as waste, and might be the possession of any other. ${ }^{86}$

Locke however went further, by also arguing that the withholding of land was considered sinful, particularly where that land was considered plentiful in supply. ${ }^{87}$ The addition of sinfulness brought with it an evangelist angle that gave colonial and settler government's a divine direction for the productive utilization of land. This element of sinful unproductiveness also gave colonisers an additional impetus to ensure that those in communal (and therefore wasteful) land ownership were speedily disinherited from it. Locke argued that

no man could ever have a just power over the life of another by right of property in land or possessions; since it would always be a sin, in any man of estate, to let his brother perish for want of affording him relief out of his plenty. As justice gives every man a title to the product of his honest industry, and the fair acquisitions of his ancestors descended to him; so

\footnotetext{
${ }^{86}$ Locke, Second Treatise, Chapter V, Section 38.

${ }^{87}$ Ibid, Chapter IV, Section 42.
} 
charity gives every man a title to so much out of another's plenty, as will keep him from extreme want, where he has no means to subsist otherwise. ${ }^{88}$

When applied to land, the message is clear. If you have more land than is required, which is either productive or unproductive, and another person requires it for their own survival, you were duty and spiritually bound to give that land to them. Locke's right of property influenced colonisers who could rationalize claims to Indigenous land by utilizing terms such as productivity and waste or idle lands. For many newly arrived settlers, the idea of owning land was based on this premise and given Indigenous people were not considered to be in individual ownership of their land or using it as prescribed by Locke, their land was available for alienation.

Furthermore, Indigenous people were considered by many early Colonialists to have irrational emotional ties to the land. ${ }^{89}$ The standards of rational behaviour, foundational to colonial thinking, had difficulty internalising Indigenous world views. Colonial values and norms drove colonial and settler development and informed the way in which New Zealand history was written leaving Māori subjected to national versions of events or colonial perspectives of how events are told. ${ }^{90}$

The study of Lot 512 could have been similarly told as initially this thesis was focused on how Crown agencies facilitated the sale of a land block in the national interest. It is still a thesis on a land block alienation, however the focal point is about the land block, the people, their social history and how they sought to maintain their land within the context of colonial development. It is for this reason, and in line with a Kaupapa Māori approach, that each chapter will begin with a tongikura from Tāwhiao that suits the chapter's theme or context. An explanation will be given of the tongikura and how it relates to the chapter topic. A brief outline will also be provided referring to Waikato or Pōkaewhenua in the time period of the chapter topic to align the chapter topic with the events in Waikato. This supports my insider's point of view, utilizing a historical

\footnotetext{
${ }^{88}$ Ibid.

${ }^{89}$ Lillian Aponte Miranda, 'Uploading the Local: Assessing the Contemporary Relationship between Indigenous Peoples' Land Tenure Systems and International Human Rights Law regarding the Allocation of Traditional Lands and Resources in Latin America', Oregan Review of International Review, 10, 2008, p. 425

${ }^{90}$ Pihama, 'Tihei Mauri Ora', 2001.
} 
analysis, entrenched within a Kaupapa Māori, kaupapa hapū and a methodology left by Tāwhiao, to build one's own whare.

\section{Te Whare Tongikura as a transformative process}

The utilisation of Te Whare Tongikura has allowed me to bring together what could have been considered disparate methodologies and concepts. Although originally inclined to utislise one methodology for my thesis such as Kaupapa Maori, this became difficult to do without minimising the important role of historiography to recount the events at Pokaewhenua, or concepts such as whakapapa and ahuwhenua that are central to my thesis. Drawing from four spaces was at first difficult as they did not immediately come together well. Utilising a framework that made sense culturally was also important, but of more importance was utilising a framework that had a connectivity to my whānau and hapū. I decided to use Tawhiao's tongikura as an analogy to explain the bringing together of methodologies and concepts.

Brad Totorewa's methodological framework provided a point of reference to show how tongikura could be used academically within a Kaupapa Māori space. Totorewa's framework then, became the foundation for developing Te Whare Tongikura as a methodological framework that comfortably housed other methodologies and concepts and articulated the lens from which my thesis was undertaken.

As a transformational process, it was carthartic. It provided the space to push back against mono-methodological processes or being constrained within a pan-Māori approach that did not always embrace an iwi based, iwi driven framework that had direct relevance to Pōkaewhenua. Te Whare Tongikura provided an ability to utilise methodologies and concepts together that did not initially appear symbiotic. Through Te Whare Tongikura, a whare was built that was able to encompass the history of Pōkaewhenua.

Having said that, Te Whare Tongikura also has a strong alignment with Kaupapa Māori as an iwi centred insider approach to the telling of history. The use of the tongikura "Māku ano e hanga i tōku nei whare" as the foundation of the Whare Tongikura and the continued use of tongikura, centering of Ngāti Hine ki Pōkaewhenua throughout this thesis, my whakapapa to this hapū and Lot 512 is an articulation of Kaupapa Māori 
methodology. This alignment with Kaupapa Māori is important as it provides the lens through which this thesis is written. The table below provides my methodological approach within Te Whare Tongikura, utilising Totorewa's framework.

Table 2: Te Whare Tongikura

\begin{tabular}{|c|c|c|c|}
\hline Tongikura & Translation & Method & Thesis Relevance \\
\hline $\begin{array}{l}\text { Māku anō e hanga } i \\
\text { tōku nei whare }\end{array}$ & $\begin{array}{l}\text { I shall fashion my } \\
\text { own house }\end{array}$ & $\begin{array}{c}\text { Māori } \\
\text { historiography }\end{array}$ & $\begin{array}{l}\text { Telling history from an } \\
\text { iwi, hapū and whānau } \\
\text { from the insider's } \\
\text { perspective }\end{array}$ \\
\hline $\begin{array}{l}\text { Ko ngā pou ō roto he } \\
\text { Māhoe, he Patete }\end{array}$ & $\begin{array}{l}\text { The support posts } \\
\text { shall be made of } \\
\text { Māhoe and Patete }\end{array}$ & Whakapapa & $\begin{array}{l}\text { The utilisation of } \\
\text { whakapapa } \\
\text { relationships to hapu, } \\
\text { whānau, whenua and } \\
\text { the experiential history } \\
\text { of agencies and their } \\
\text { values. }\end{array}$ \\
\hline $\begin{array}{l}\text { Ko te tāhuhu, he } \\
\text { Hinau }\end{array}$ & $\begin{array}{l}\text { The ridgepole is of } \\
\text { Hinau }\end{array}$ & Kaupapa Māori & $\begin{array}{l}\text { The core values that } \\
\text { underpin and validate a } \\
\text { cultural research } \\
\text { paradigm and method } \\
\text { of engagement with the } \\
\text { research area and } \\
\text { community. }\end{array}$ \\
\hline $\begin{array}{l}\text { Me whakapakari ki te } \\
\text { hua o te Rengarenga }\end{array}$ & $\begin{array}{l}\text { The inhabitants shall } \\
\text { be raised on } \\
\text { Rengarenga }\end{array}$ & Ahuwhenua & $\begin{array}{l}\text { The ability to analyse } \\
\text { colonial language and } \\
\text { intent regarding Māori } \\
\text { productivity and } \\
\text { perceived notions of } \\
\text { waste land. }\end{array}$ \\
\hline $\begin{array}{l}\text { Me whakapakari ki te } \\
\text { hua o te Kawariki }\end{array}$ & $\begin{array}{l}\text { And nurtured on } \\
\text { Kawariki }\end{array}$ & Research Methods & $\begin{array}{l}\text { The layered and } \\
\text { multidisciplinary } \\
\text { methods used to gather } \\
\text { information and } \\
\text { knowledge. }\end{array}$ \\
\hline
\end{tabular}




\section{Me whakapakari ki te hua o te kawariki: Research methods}

The methods used to gather information and knowledge for this thesis were layered and multidisciplinary. I used archival materials, literature sources and Māori Land Court minute books, which provided an overwhelming amount of information, particularly with regard to the Parish of Whangamarino, the agents of alienation and the alienation practices in Lot 512. The majority of this information are primary sources and unpublished elsewhere and involved records predominantly from Archives New Zealand offices in Auckland and Wellington and the Māori Land Court office in Hamilton. Unfortunately, repeated requests to the Māori Trustee in Hamilton and Wellington to access the files for Lot 512A (one of which was sealed in Auckland's Archive New Zealand office) were ignored. Numerous emails and phone calls, proof of whakapapa and a narrow scope of information requested, went unanswered. This is disappointing. There was more than adequate information on Lots 512B-F, but the land files for Lot 512A remain sealed. The memorial schedule for this block allows enough information to draw conclusions but leaves a gap that in my mind, provides a limitation to this thesis.

Other key documents from Archives New Zealand include reports, telegrams and official documents on Pōkaewhenua-Lot 512 stretching back to confiscation and through to compensation in the 1880s and Māori Land Court sittings in the 1920s, 1930s and 1960s. Letters, memos and briefings within the Department of Māori Affairs were also accessed focusing primarily on Māori land use and productivity including the attitude of sitting Judges and policy officers in their promotion of land alienation during the 1940s-1960s, and the processes used to disenfranchise Māori owners of land in the Parish of Whangamarino.

Appendices to the Journals of the House of Representative (AJHR) records also provided information on Ngāti Hine at Waikare back to 1853 as well as the thinking of the day and rationale behind confiscation in the $1860 \mathrm{~s}$, alienation and the language behind productivity through the first half of the twentieth century. 
To provide context to those living in Pōkaewhenua during the 1940s and 1950s, I also had conversations with whānau that were undertaken before this $\mathrm{PhD}$, during the thesis and will no doubt be on-going as whānau members take up their own parts of the story.

The importance of the interviews and group hui process was to ensure that relevant local stories are told by those who lived and participated in Lot 512 around the time span covered. Although criteria was in some ways prescribed by Victoria University for the interview process, I supported this criteria with a whānau approach which required talking with kaumātua about the thesis well before the ethics process. Before my kaumātua imparted knowledge however, there was a necessary precursor that the person receiving that knowledge is both worthy of it and will not misuse it and within my whānau, this process could take years and in some rare occasions, may not happen at all.

The interview process with Ngawini Puru was lengthy and took place over a period of time. By the time the formal interview was undertaken it was less about starting a conversation from the beginning, than one of rechecking, confirming, verifying and validating information gathered during more culturally appropriate kōrero. Conversations with other whānau members had also taken place over a period of months, none of which were recorded but were conveyed for context and freely given.

As is the custom with my whānau, an interview with my Kuia was preceded by kai and five hours of waiting before the kōrero took place. It was important, in this whānau process to ensure my Kuia was comfortable, that she knew the time she was giving and the information imparted was respected and valued.

Once the interview was completed, there is no discernible end. That is not how my Kuia functions, particularly given that in her mind, the conversation will continue (regardless of this thesis) until she has decided it has run its course or there is nothing left for her to share.

Other conversations have been taken up by the wider whānau, all sharing, confirming, validating knowledge given and although these conversations are not a formal part of this thesis process, they are no less important. They form the multi-layered foundation of knowledge, which wraps around and validates the kōrero provided by this research. 
The knowledge is equally important and valid, informing, growing, and coalescing, while at the same time channelled through a whānau member that is closest to me. Although these wider stories cannot be a part of this thesis, they are vital to the ongoing story of Pōkaewhenua that reaches beyond this one telling of Lot 512.

As a method of reciprocity, feedback hui have been undertaken to share information to the whānau and to kōrero about preliminary findings. All those present at the hui were owners or beneficiaries of Lot 512. Feedback hui were held in Hamilton (five times), Auckland, Brisbane, and Okarea during 2012 and 2013. As a key part of Kaupapa Māori methodology, the process had gone full circle. The whānau had requested that the research of Lot 512 be undertaken and they have been supportive throughout, both in giving and receiving information and demanding integrity throughout the research period.

Although the study of Lot 512 utilises Māori historiography and Kaupapa Māori, my whare tongikura is instrumental in gathering the threads of other concepts, which are lashed together to build my whare. 


\section{CHAPTER THREE: MAI RANGIRIRI - COLONISATION}

Ko te pakanga i runga i tenei motu. Kua rite ki te kōkā harakeke. Ko te tangata whakaara pakanga ā muri ake nei, koia tonu hei utu

Beware of being enticed to take up the sword. The result of war is that things become

like decaying, old dried flax leaves. Let the person who raises war beware, for he himself will pay the price. ${ }^{91}$

The crossing of the Mangatāwhiri River and the battle of Rangiriri in Waikare seared in Waikato minds, the duplicity of the Crown, their motives and the lengths they would go to in order to carry out their colonial project. Tāwhiao was present at the battle of Rangiriri and although he begged his people to withdraw to safety with him, over two hundred remained on the battlefield to ensure he escaped. ${ }^{92}$ Afterwards, Tāwhiao referred to Rangiriri and the invasion of Waikato by reciting the tongikura above, both as a metaphor for his people and as a reminder of the ways of the Crown.

The hapū of Ngāti Hine occupied the area around Lake Waikare, which included pā sites at Rangiriri, Takapūruharuha and Pōkaewhenua. Ngāti Hine had whakapapa links to Ngāti Marae, Ngāti Mahuta and Ngāti Whānaunga (of Hauraki). During the period prior to and following the invasion of Waikato, Ngāti Hine had a broad economy that supplied Auckland with flour, wheat, pigs, wood, potatoes, onions, cabbages, peaches, maize, kumara, fish, bundles of grass, goats and kauri gum. ${ }^{93}$ The amount of exports to Auckland changed dramatically after the invasion of Waikato from the equivalent of today's monetary values of $\$ 1.9$ million today (or $\$ 475,000$ per year) over a four year period to $1859^{94}$ to sporadic and minimal exports of potatoes following the invasion.

\footnotetext{
${ }^{91}$ Turongo House, Tāwhiao, p.87.

${ }^{92}$ Ibid.

${ }^{93}$ John Williamson, 'Return of Native Produce Imported into the Ports of Auckland and Onehunga', AJHR, Session I, E-No.12, 11 August 1865, p.4-14.

${ }^{94}$ Brian Easton's calculation of the value of a pound in 1863 to its equivalence in 2003 at http://www.eastonbh.ac.nz/2004/03/what was a pound worth/
} 
In 1863, those Ngāti Hine living in Pōkaewhenua and Takapūruharuha joined in the battle at Rangiriri and were subsequently labelled as rebels. ${ }^{95}$ As a means to cut off any further support for the Kingitanga and to eliminate trade links to the ports at Auckland and Onehunga, the Crown set up a number of redoubts including Queen's Redoubt in Pokeno, which was the launching point for invading the Waikato; Eglinton Redoubt, four kilometres south of Pōkeno; Koheroa Redoubts, along the Koheroa ridge (Kellyville Road southwards to the Whangamarino wetlands); Whangamarino Redoubt (next to Te Teoteo's Pā at the confluence of the Waikato and Whangamarino Rivers); and the Miranda Redoubt in the Hauraki (see Map 2).

The Miranda Redoubt was of particular importance as Waikato and Hauraki Māori had built rifle pits a mile long at Pūkorokoro, including blocking the mouth of the Pūkorokoro River with pohutukawa trees. ${ }^{96}$ Two warships, the Miranda and Sandfly, had already shelled three pā and a redoubt had been established at Pūkorokoro to deal with the fighting in that area and to stop the easy access Kingitanga fighters had across the Hunua and Wairoa ranges. ${ }^{97}$ The Surrey Redoubt and Esk Redoubts were “constructed along the Miranda to Manga-tawhiri [sic] line, linking up with the Queen's Redoubt" in Pokeno. ${ }^{98}$ The current township of Miranda then takes its name from the warship that bombed three of its pa sites at Pūkorokoro, which is a short distance from Ngāti Hine at Pōkaewhenua, and an area that was an important mahinga kai site for Te Ao Mārama’s whānau.

Other redoubts included Te Wheoro's Redoubt at Rangiriri, which effectively cut off any on-going trade to Auckland or further ability for those whānau still in the area to join in the fighting elsewhere.

Ngāti Hine, until 1863, had been living peaceably in the Waikare area and as firm Kinngitanga supporters were prepared to defend their economic base at Rangiriri. Te Ao Mārama's mother, Kauia and her sister Kahutoroa had married brothers from Ngāti Mahuta, Tamehana Te Ketetauaro and Wahienui Tamehana (otherwise known as Te $\mathrm{Kau}$ ). The proclamation following the invasion of Waikato was clear about its intent

\footnotetext{
${ }^{95}$ James Belich, The New Zealand Wars and the Victorian Interpretation of Racial Conflict, Auckland, Penguin Books, 1998, p.144.

${ }^{96}$ James Cowan, The New Zealand Wars: A History of the Māori Campaigns and the Pioneering Period: Volume I: 1845-1864, Wellington, R.E. Owen, 1955, p.322.

${ }^{97}$ Ibid.

${ }^{98}$ Ibid, p.323.
} 
regarding land confiscation for those who rebelled against the Crown. Although Kauia, Kahutoroa and Te Wahienui stayed to fight with Tāwhiao at Rangiriri, Tamehana left to fight with the Crown. ${ }^{99}$ Despite this, at the conclusion of fighting in the Waikato, Tamehana returned to Kauia in Pōkaewhenua and in 1878, Te Ao Marama was born.

\section{Map 2: Map of Redoubts in Lower Waikato ${ }^{100}$}

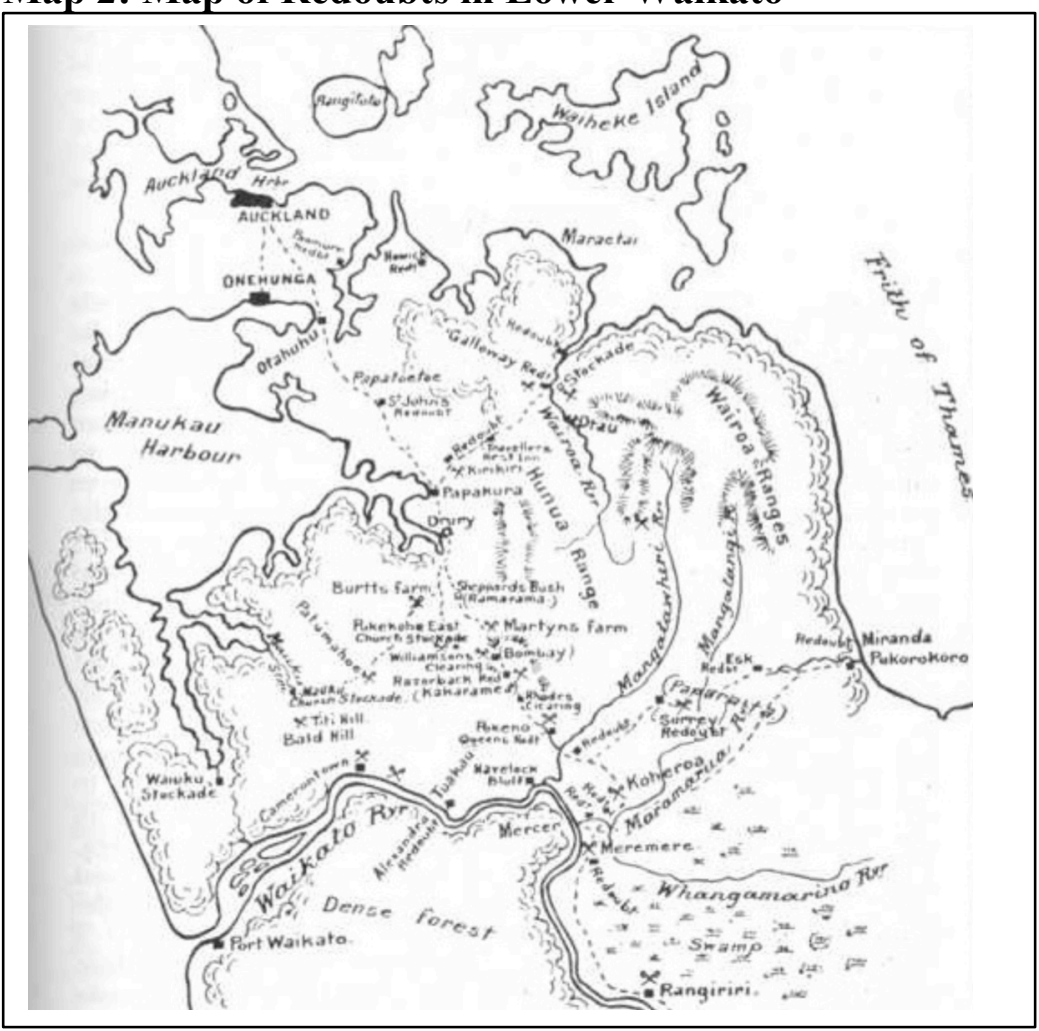

The purpose of this chapter is to show how the practice of colonisation and confiscation was applied in the 1860s and the impact this had on Waikato. This chapter argues that colonisation in New Zealand focused on the acquisition and utilisation of land and in doing so, denigrated Māori land use as inferior, wasteful and unproductive. I argue that the needs of the emerging colony and migrating settlers agitated for access to Māori lands by any means possible, including war. This pressure culminated in the invasion of Waikato and the confiscation of 1.2 million acres of Waikato land through the New Zealand Settlements Act 1863, for settlement.

\footnotetext{
${ }^{99}$ See Mercer Minute Book, 'Whangamarino 335', Volume 13, 17 January 1910, pp.94-5

${ }^{100}$ Map downloaded from http://en.wikipedia.org/wiki/Invasion of Waikato on 30 October 2013.
} 
I also outline five key aspects of confiscation that were undertaken in New Zealand as a basis for considering later whether the facilitated alienation of Pōkaewhenua was also confiscation.

\section{Colonisation}

British colonisation was an act of cultural arrogance and aggression "inspired with a passion to 'improve' other peoples". ${ }^{101}$ Although the economic rationale for colonisation included the expansion of British markets, the methods to acquire those markets involved an aggression that brought violence which resulted in widespread displacement of Māori.

One of the primary goals of British colonisation in the nineteenth-century was to ensure that land became available for arriving settlers by displacing Māori from their land and secondly instituting a process that allowed land to be sold to settlers through Crown grants. Internationally, colonisers preferred extermination to displacement as a means of domination but where extermination was neither possible nor preferable, indigenous people were forcibly alienated from their land. ${ }^{102}$ Robert Young argues that

Natives, if not exterminated were moved out of their land that they had previously occupied. ${ }^{103}$

Richard Boast and Richard Hill argue that in New Zealand

Land was taken to be settled...the taking and the settling were linked, part of a single policy. ${ }^{104}$

Colonisation in New Zealand was a part of the wider policy of British colonisation as experienced elsewhere in the world and involved the mass migration of 22.5 million Britons between 1815-1915 to its "white" colonies including New Zealand. ${ }^{105}$ Colonisation had two modes of operation, the first was bringing colonised Indigenous

\footnotetext{
${ }^{101}$ Ronald Hyam, Britain's Imperial Century, 1815-1915: A study of Empire and Expansion, Hampshire, Palgrave MacMillan, 2002, p.75.

102 Robert Young, Postcolonialism, Oxford, Blackwell Publishers, 2001, p.20

${ }^{103}$ Ibid, p.20.

${ }^{104}$ R.Boast and R. Hill, 'Overview: Confiscation in New Zealand' in Richard Boast and Richard Hill, eds., Raupatu: The confiscation of Māori Land. Wellington, Victoria University Press, 2009, p.6.

${ }^{105}$ Kent Fedorowich, 'The British Empire on the Move' in Sarah Stockwell, ed., The British Empire:

Themes and Perspectives, Oxford, Blackwell Publishing, 2007, p.63.
} 
people into the dominion of the Crown while still allowing the state to be quasi independent or secondly "they may be brought (as far as possible) even from the beginning within the law and political system of the colonizers" and thereby became subjects of the Crown. ${ }^{106}$ The key purpose of colonisation William Fox argued was to establish "some settled form of government, which might restrain and protect both the natives and the settlers who were then flowing into [New Zealand]". ${ }^{107}$

The New Zealand colony was created under the Charter for Erecting the Colony of New Zealand, which established a Legislative Council to make laws consistent with the Privy Council in England and an Executive Council "to advise and assist the Governor...in the administration of the government". ${ }^{108}$ The Legislative Council included the Colonial Secretary, Treasurer and Attorney General. The Colonial Secretary was responsible for establishing a "colonial code" related to the duties of the local government, the Treasurer for the "improvement of and security of the [colony's] revenue" and the Attorney General for developing legislation related to "the general protection of property, and for the prevention and punishment of crime". 109

In New Zealand, colonial administration was legislated under the New Zealand Constitution Act of 1852 which created government and separate administrations, including a superintendent and six provincial councils in Auckland, New Plymouth, Wellington, Nelson, Otago and Canterbury. ${ }^{110}$ Native Affairs was the sole domain of the Governor General until 1856 and according to Governor Gore Browne, one of the key purposes of Government. The duty of the newly formed Parliament, was to

preserve and advance in the scale of civilisation the Native inhabitants of these Islands; to develop the resources of a country rich in all the elements of future national greatness; to be the pioneers for its colonisation by the

\footnotetext{
${ }^{106}$ William Fox to Governor Grey, 'Observations on the Proposal to take Native lands under an Act of the Assembly', Papers Relative to Confiscation of Native Lands, AJHR, E-No.2b, 31 December 1863, 1864, p.4.

${ }^{107}$ Ibid, p.5

${ }^{108}$ Lord John Russell to Governor Hobson, 'Charter for erecting the Colony of New Zealand, and for creating and establishing a Legislative Council and an Executive Council, and for granting certain powers and authorities to the Governor for the time being of the said Colony', Correspondence Respecting the Colonization of New Zealand, British Parlimentary Papers, No.17, Enclosure 1, 9 December 1840, p.32 Downloaded from http://digital.liby.waikato.ac.nz on 30/06/2013.

${ }^{109}$ Ibid, p.25.

${ }^{110}$ Bernard Attard, 'From Free-trade Imperialism to Structural Power: New Zealand and the Capital Market, 1856-68', The Journal of Imperial and Commonwealth History, 35, 4, 2007, p.508.
} 
Anglo-Saxon race; to lay the foundation of its religious, political and social institutions; to give laws to the present and to influence the character of a future generation. ${ }^{111}$

This was a significant platform for the new Parliament. While dealing with the issue of the "Native Inhabitants", it also set out the key focus for its elected parliamentarians, a focus that clearly indicated that Native Affairs and the development of the colony were two significantly separate agendas. The point has already been made in this thesis that the two are inextricably linked given land acquisition required the subjection of Māori people for greater access to their land. Māori use of their land was considered wasteful by virtue of their wide and communal ownership and seemingly narrow actual occupation. Those lands not in actual occupation were considered waste lands and the Charter establishing the colony was clear in its demarcation between the two. According to the Charter

nothing... shall affect...the rights of any aboriginal natives of the said colony of New Zealand, to the actual occupation or enjoyment in their own persons, or in the persons of their descendants, of any lands in the said colony now actually occupied or enjoyed by such natives. ${ }^{112}$

One of the elected members, James Fitzgerald, pointed to land acquisition as the preeminent focus for the colony. Fitzgerald argued that

the subject was one, which demanded much consideration, it being in fact, the question of the greatest importance of all questions to the colony, on which the entire policy of the country with respect to all other matters must hinge and depend. ${ }^{113}$

Instructions from Hobson to the Governor General directed that lands purchased from those Māori willing to sell were to be paid at a nominal price fixed by the Imperial Government. ${ }^{114}$ The first price set for Māori land was £1 per acre, with a limit of 2,560 acres per transaction, but this was revised to 10 shillings per acre after pressure from

\footnotetext{
${ }^{111}$ Thomas Gore Browne, 'Governor's Speech' in the Legislative Council, NZPD, 27 May 1854, p.13.

${ }^{112}$ Russell to Hobson, 'Colonization of New Zealand', p.25.

113 James Fitzgerald, 'Waste Lands Bill, NZPD, 30 June 1854, p.168.

${ }^{114}$ E.J. Aims, 'Dual Control of Native Policy - A Phase of Responsible Government in New Zealand'. M.A Thesis, Victoria University of Wellington, 1929, p.4.
} 
settlers to reduce the price. ${ }^{115}$ When this reduction in price failed to initiate further sales, the Governor then waived its pre-emptive right allowing settlers to purchase directly from Māori for "one penny per acre". 116 This was despite an Instruction from Normanby to treat Māori with "sincerity, justice and good faith". ${ }^{117}$ The devaluing of Māori land to suit settler demands was an enduring theme into the 1960s and will be examined in more detail in Chapter Four.

When it came to determining whose interests were being served during colonisation, it is clear that it was predominantly the interests of the Crown and settlers. Although there were elements of the colonial and settler community that were sympathetic towards Māori and their interests, the majority of settlers arrived in New Zealand with the view to make a new and improved life for themselves which was mutually aligned to existing settlers in the colony. ${ }^{118}$ In order to do that, access to land at cheap prices was necessary.

Migrating settlers to New Zealand brought with them a desire to re-create the country they had left behind and in doing so, on arrival settlers encountered Indigenous owned land that was considered an impediment to establishing a colony that could promote their economic interests and ways of life. ${ }^{119}$ For Colonists, ${ }^{120}$ land could be acquired in three main ways: by conquest; through law; or cession "from a foreign State or from a subject". ${ }^{121}$ Land taken by military force through war, was considered conquest however, land taken via legislation fell into three categories:

(a) by forfeiture upon conviction of treason in a court of law

\footnotetext{
${ }_{115}^{115}$ Aims, Dual Control, p.4.

116 Ibid.

${ }^{117}$ The Marquis of Normanby to Captain Hobson, 14 August 1839 in Alexander MacKay, 'A

Compendium of Official Documents relative to the Native Affairs in the South Island', Volume 1,

Nelson, Luckie and Collins, 1872, p.15.

${ }^{118}$ Danny Keenan, Wars without end: The Land Wars in Nineteenth-Century New Zealand, Auckland, Penguin Books, 2009, p.58 and Keith Sinclair, The Origins of the Māori wars, Wellington, New Zealand University Press, 1957, p.4.

${ }^{119}$ Robert Johnson, British Imperialism, Basingstoke, Palgrave MacMillan, 2003, p.19.

${ }^{120}$ Settlers are considered in this thesis as immigrants and Colonists as the colonial government or members of the House of Representatives. The Crown refers to the Governor or the Home Government in London.

${ }^{121}$ William Martin to William Fox, Observations on the Proposal to take Native lands under an Act of the Assembly, 16 November 1863, in Papers Relative to Confiscation of Native Lands, AJHR, Session I. ENo.2b, 1864, p.4.
} 
(b) by Act of Attainder, ${ }^{122}$ resorted to by Parliament in extraordinary cases, where a regular trial for treason is not practicable; in which cases, however, though the forms of the law of treason be departed from, the substance is to be closely adhered to.

(c) Or, thirdly, by a special legislative enactment, authorising the Executive Government to take the land of a subject for the purpose of public defence, or for any other national purpose; the land being in such cases taken under such restrictions and upon such terms of compensation to the private owners as Parliament may prescribe in the Act. ${ }^{123}$

All three categories refer to treason as a reason for land acquisition by the Crown. Treason as it applied to confiscation will be discussed in more detail later in the chapter.

Given land in the new colony was considered 'owned' and utilised by Māori and the economy was also controlled by them, colonisation sought to reverse this and by acquiring land to also acquire the autonomy to control and develop land for their own purposes. James Belich argues that

the expansion of the area of real British control was inextricably interwoven with the purchase of Māori land. Conversely, to oppose land sales was to oppose the extension of British sovereignty and to defend Māori autonomy. $^{124}$

It is difficult to perceive Māori land interests being a focal point for the colony or settlers once a process of settlement or colonisation was advanced. Inherently, colonisation and settlement is predicated on the settlers' interests of developing a sustainable economic base for settlers that allowed settlers to be independent (or at least in a stronger inter-dependent relationship) of indigenous people.

Although the Americas and other continents took the bulk of the migrants leaving Europe during the nineteenth-century, those that made the voyage to New Zealand through various schemes were sold on the idea of establishing a newer, more refined

\footnotetext{
${ }^{122}$ Attainder is the "the forfeiture fo land and civil rights suffered as a consequence of a sentence of death for treason or felony". Translation from the Oxford Dictionary at http://www.oxforddictionaries.com/definition/english/attainder?q=attainder accessed on 12 June 2014 ..

${ }^{123}$ Martin, 'Proposal to take Native Lands', p.4.

${ }^{124}$ Belich, The New Zealand Wars, p.78
} 
Britain than the rebellious Americans or convict Australians, which included the ability for settlers to access land and rise above the social station they were leaving. ${ }^{125}$

However, on arrival, settlers learnt about the Treaty of Waitangi which gave Māori absolute authority over their land and the pre-emptive right of land acquisition granted to the Crown, which appeared to be impediments to settler interests. ${ }^{126}$ Settler dissatisfaction with Māori land rights and Crown pre-emption became more pronounced during the 1840s and 1850s, and in particular was directed at Article 2 of the Treaty, which gave the impression that those rights were secured to Māori. ${ }^{127}$

Settler antagonism was also fuelled by an economy predominantly reliant on Māori for tax revenue, land and food. Sinclair argues that:

it was obvious that the chief way of making money in New Zealand was going to be by farming...If the Maoris [sic] farmed for profit, they competed with the settlers. If they retained their old economy [for fishing, harvesting, hunting], the rivalry was greater [which required a] relatively large expanse of land...for their cultivations. ${ }^{128}$

The convergence of these competing interests became an issue for the Crown. On the one hand, the Crown appeared to be obligated to abide by the Treaty of Waitangi, while on the other, settler demands and the Crown insisted that land be made available for farming. In reality, the Crown wasted little time advocating and legislating for settler interests. One year after the signing of the Treaty, the New Zealand Land Claims Ordinance was passed by the Legislative Council which declared that all unoccupied land in the colony to be in the "domain lands of Her Majesty". Section 2 stated that:

all unappropriated lands...subject however to the rightful and necessary occupation and use thereof by the Aboriginal Inhabitants... are and remain Crown or domain lands of Her Majesty. ${ }^{129}$

\footnotetext{
${ }^{125}$ Belich, The New Zealand Wars, p.78

${ }^{126}$ Keenan, War without end, p.50.

127 ibid, pp.47-48.

${ }^{128}$ Ibid, pp.4-5.

${ }^{129}$ Section 2 of the New South Wales Act 1841.
} 
Danny Keenan argues that the Crown had to make provision somewhere for settlers "who were arriving with expectations of acquiring land to develop new settlements, economies and livelihoods". 130

In 1845, the New Zealand Company lobbied the House of Commons to establish a Select Committee to enquire into the New Zealand colony with a view to making land available to settlers. ${ }^{131}$ Having created the Select Committee, the House of Commons then advocated in favour of the New Zealand Company and reiterated that the colony be administered according to the interests of the Crown. ${ }^{132}$ Those interests as they pertained to Māori land were that land used for occupation or agricultural pursuits included crops, cattle or subsistence gardens could be retained by Māori. Any land considered idle was seen by the Committee to be waste land and therefore open for settlement. $^{133}$ The Royal Instructions to Governor Grey stated that

No claims shall be admitted in the...Land Courts on behalf of the aboriginal inhabitants of New Zealand to any land...unless it shall be established...[that] the right of such aboriginal inhabitants to such lands have been acknowledged or ascertained, or those from whom they derived the title, have actually had the occupation of the lands so claimed, and have been accustomed to use and enjoy the same, either as places of abode or tillage, or for the growth of crops, or for the depasturing of cattle or otherwise for the convenience and sustentation of life hereon. ${ }^{134}$

Legislation was subsequently put into place primarily in the interests of the Colonists and settlers, which essentially omitted Māori input into the drafting and passing of legislation and consequently ensured that Māori interests were largely ignored. ${ }^{135}$ Louis Chamerovzow, an anti-slavery campaigner and humanitarian who was also Assistant to the Secretary of the Aboriginal Protection Society from 1847-1852, argues that

\footnotetext{
${ }^{130}$ Keenan, War without end, p.51.

131 Jack McKinney, 'The Evolution of a Legal Title to Land formerly held under Native Custom and Usage', Doctoral Dissertation, Victoria University College, 1939, p.15.

${ }^{132}$ Ibid, p. 15.

${ }^{133}$ Earl Grey to Governor Grey, 1846 in McKinney, Evolution of Legal Title, p.17.

${ }^{134}$ Ibid.

${ }^{135}$ Louis Chamerovzow, The New Zealand Question and the Rights of Aborigines, London, T.C Newby, 1848, p.323.
} 
The Aborigines of New Zealand are not denied the possession of interests, in common with the colonists, nor is the fact disputed that these interests require uniformity of legislation: yet the former are excluded from a participation in the passing of enactments material to the vitality of these interests they being exfranchised from the Municipal Corporations which are established for the especial behoof of the colonists. ${ }^{136}$

For Earl Grey, Secretary of State for the Colonies, and Governor Grey, those lands that fell outside of the prescriptive utilisation outlined in the Royal Instructions, were considered waste lands. ${ }^{137}$ Jack McKinney argues that settlers felt that "steps must be taken to enable utilisation to be made of the millions of acres of native land lying waste and producing nothing". ${ }^{138}$

Māori contribution to the colony was significant. In the Waikato alone there were 12 flour mills either in operation (10) or under construction (2) with another 5 mills proposed in the region. ${ }^{139}$ Of these mills, Rangiaowhia was considered the "showplace of Māori agriculture [and expected to be the] granary of the North Island as well as a major cattle breeding area without peer in the colony". ${ }^{140}$

Graham Harris and Percy Tipene argue that:

Māori were an adaptable and pragmatic people who adopted many of the systems concepts and items such as tools and crop plants, introduced by the European settlers and adapted them to their own need - often making improvements in the process. ${ }^{141}$

The adoption and adaptation of Pākehā crops was extensive. A range of fruit and vegetables was grown successfully and included cabbages, onions, carrots, turnips, marrows, beans, apples, peaches, quinces, cherries and grapes, water melons and oats,

\footnotetext{
${ }^{136}$ Ibid, p.325.

${ }^{137}$ McKinney, Evolution of Legal Title, p.18.

${ }^{138}$ Ibid, p. 21 .

${ }^{139}$ Raymond Hargreaves, 'The Māori agriculture of the Auckland Province in the mid-nineteenthcentury', Journal of the Polynesian Society, 68, 2, 1959, p.71.

${ }^{140}$ Ibid.

${ }^{141}$ Graham Harris and Percy Tipene, 'Māori Land Development' in Malcolm Mulholland et al, eds., State of the Māori Nation: twenty first century issues in Aotearoa, Auckland, Reed Publishing Ltd, 2006, p.69.
} 
barley and tobacco. ${ }^{142}$ During the 1852-1856 period Māori sent 285,937 bushels of wheat, 90,798 bushels of maize and 3,975 tons of potatoes into Auckland by coastal vessel or canoe for trade. ${ }^{143}$ There are no records for back-borne produce and in the main, produce was carried via the waterways of rivers and coastal carriage. The value of this produce is considered by Hargreaves to be in the vicinity of $£ 16,000$ annually or in today’s currency, worth $£ 936,480$ or NZ\$1,909,126 over that four year period. ${ }^{144}$ This is a considerable contribution to the local economy given Māori (in comparison to today's technology) used relatively labour intensive tools and lived a supposedly "backward" and "traditional" lifestyle. In addition to supplying food to the Auckland market, Robert Mahuta saw Waikato's contribution as twofold: securing the city's safety from a possible Ngāpuhi attack and supplying Auckland with "the foodstuffs necessary for its survival. ${ }^{145}$

Ngāti Hine also contributed to the "export" of food from Waikato to Auckland. Māori Land Court records show that the hapū invested $£ 800$ for a flour mill, had cleared and established a dairy farm and grown wheat on the land, as well as planted and harvested potatoes. $^{146}$

For Māori, their rights to their land had been secured under Article 2 of the Treaty of Waitangi and their developing economic expansion had allowed Māori to capitalise on their trade with Auckland and maintain autonomy over their lands. ${ }^{147}$ For the settlers however, the major impediment to their interests and the colonisation project was Māori customary title and its continuing possession in Māori hands. ${ }^{148}$ Settlers considered lands that appeared unutilised, as wasteful and encouraged settler dissatisfaction. However, settlers conceived any land without a house or utilised in a European way as wasteful regardless of the actual use by Māori. ${ }^{149}$ As an example, bush land used for

\footnotetext{
${ }^{142}$ Ibid, and Hargreaves, Agriculture of Auckland, p.71.

${ }^{143}$ Hargreaves, Agriculture of Auckland, p. 74

${ }^{144}$ Ibid and the UK National Archives website and MoneyConverter.com for today's currency values. Please also note that pounds, shillings and pence have been converted to decimal currency.

${ }^{145}$ Robert Mahuta, 'Tainui, Kīngitanga and Raupatu' in M Wilson and A Yeatman, Justice and Identity: Antipodean Practices, Wellington, Bridget Williams Books Ltd, 1995, p.20.

${ }^{146}$ Tarehurangi Te Waari, 'Whangamarino 512', Mercer Minute Book, Volume 16, 23 January 1912, p.233 and Judge McCormick, 'Whangamarino Decision', Mercer Minute Book, Volume 24, 27 August 1927, p. 276.

${ }^{147}$ McKinney, Evolution of Legal Title, p.27

${ }^{148}$ Keenan, War without end, p.51.

${ }^{149}$ Ibid, p.50.
} 
hunting kererū, tui, weka, kākā or kiwi, or for gathering kouka, aruhe, berries, fungi and palms were often considered scrub land that needed to be 'broken in', farmed or mined. ${ }^{150}$ Keenan argues that:

As the subsequent deadlock between sales and settler aspirations grew, settlers became increasingly intolerant of Māori refusals to sell land, which threatened the expansion of settlement and economic prospects. Demands increased that Māori be forced to part with their land, with all rights removed. $^{151}$

Setter and colonial interests focused on the acquisition, by any means possible, of Māori land and the development and expansion of their own economies. ${ }^{152}$ In doing so, and by virtue of the concept of productiveness, settler and colonial interests were at odds with Māori.

By 1856, the sole discretion held by the Governor to oversee Native Affairs was changed with the passing of the Native Reserve Act, giving Ministers in the House the ability to "interfere in native affairs". ${ }^{153}$ The Ministers in the House were predominantly focused on promoting settler interests so devolving Native Affairs allowed a sharper focus on alienating Māori land and Parliament deciding what were in the best interests of Māori. That is not to say that the Governor had always been a staunch supporter of Māori, but rather that Māori needed only appeal to one person rather than the many in the House until they were given their own representation in $1867 .^{154}$ With the fate of Māori interests in the hands of settler Ministers, the prevailing Pākehā attitude towards Māori was that Māori were savages, incapable of utilising the land they claimed and therefore were neither civilised or capable of bringing that land into production. ${ }^{155}$

\footnotetext{
${ }^{150}$ Sinclair, Origins of Māori War, p.5.

${ }^{151}$ Keenan, War without end, p.51.

152 Ibid.

${ }^{153}$ McKinney, Evolution of Legal Title, p.28.

${ }^{154}$ Richard Boast, Buying the Land, Selling the Land: Government and Māori Land in the North Island 1865-1921, Wellington, Victoria University Press, 2008, p.26.

${ }^{155}$ Sinclair, Origins of Māori war, p.7.
} 
A central premise of colonisation appeared to be that wherever civilisation was lacking, European superiority protected and determined aboriginal interests as they were incapable of doing so themselves. Sinclair argues that

To most of the European settlers, who looked on primitive peoples with the sympathetic eye neither of the romantic nor of the anthropologist, the Maoris [sic] were simply savages. There was little or nothing to be said in favour of the way in which they lived...The Māoris [sic] were said to be gossiping, slovenly, lazy, like all men in a savage state. ${ }^{156}$

Robert Williams also argues that indigenous people were considered

distant, alien, uncivilised being, unaware of either the benefits or burdens of modernity. Lacking in sophisticated institutions of government and religion, ignorant of property and laws, without complex social bonds or familial ties, living in a state of untamed nature, fierce and ennobled at the same time, the savage has always represented an anxious, negating presence in the world, standing perpetually opposed to Western civilisation. ${ }^{157}$

As both Sinclair and Williams suggest this was not an uncommon view at the time and was symptomatic of John Locke's influence in shaping the ideology behind colonisation. As mentioned in the previous chapter, colonisation was imbued with the idea that the British had superiority over indigenous peoples based on the grounds that they did not "make proper use of their lands". ${ }^{158}$ Locke considered any land left communally owned and in Indigenous ownership was wasteful and the withholding of it by those better able to utilise, sinful. ${ }^{159}$

Correspondence by Fred Carrington (a Government engineer and surveyor) to Governor Gore Browne regarding land acquisition in the Taranaki region, conveyed similar themes. Fred Carrington argues that

\footnotetext{
${ }^{156}$ Sinclair, Origins of Māori war, pp.6-7.

${ }^{157}$ Robert Williams, Savage Anxieties: The Invention of Western Civilisation, New York, Palgrave MacMillan, 2012, p.1.

${ }^{158}$ Buchan, 'Indigenous government', p.4.

${ }^{159}$ Locke, Second Treatise, Chapter IV, Section 42.
} 
the Chiefs, with few exceptions are degraded savages, are jealous of each other...hence it follows that these poor ignorant beings become exasperated with each other, and deeds of blood and murder, and the most revolting acts have ensued from this present mode of acquiring land in this settlement. ${ }^{160}$

Governor Gore Browne, himself, articulated this same view point, that Māori were uncivilised savages that required the removal of their land to allow settlers the ability to productively utilise it. Gore Browne, in writing to the Duke of Newcastle argued that

Soon, therefore, a want of available land will really be experienced, and it cannot be concealed that neither law nor equity will prevent the occupation of Native lands by Europeans... and then it will be seen whether or not the Maories [sic] will prove an exception to the rule which seems universal, viz., that the Aboriginal savages must fade away before their civilised brethren. ${ }^{161}$

Gore Browne, the sole advocate in the colony for Native Affairs, had the same underlying concept of Māori as an uncivilised savage that necessitated the taking of their land so his "civilised brethren" could better use it. Gore Browne was responding, in particular to a Member of the Auckland Provincial Council who had stated in the Council Chambers that

What right (for instance) had a parcel of Natives at Coromandel - like dogs in a manger - to keep everybody out of that rich district? People would soon begin to act on the old principle of letting land belong to those who can keep it. It was impossible to prevent the Anglo-Saxon overcoming the Natives; and the Europeans, if they could not get land with the consent, must get it without the consent of the Government. ${ }^{162}$

Gore Browne was well aware of the sentiments of the settlers and from his comments appeared to agree. Gore Browne's conviction was such that he believed settlers would acquire Māori land "recte si possint, si non quocunque modo". ${ }^{163}$ Gore Browne's

\footnotetext{
${ }^{160}$ Carrington Letter to Gore Browne, p.2.

${ }^{161}$ Gore Browne, Letter to Duke of Newcastle, p.3.

162 Gore Browne to the Duke of Newcastle, AJHR, Session I, E-No.6A, 20 September 1859, 1860, p.2.

${ }^{163}$ Translated as "fairly if possible, if not, then by any means at all" in Gore Browne, Letter to Duke of Newcastle, p.2.
} 
perception was that Māori were "less human than the settlers" 164 and that wherever or however possible, those lands that were in excess to Māori requirements or more accurately "not only useless but harmful to the Aborigines, and which will soon be required for colonization [sic] by the Europeans" should be taken from them. ${ }^{165}$ Sinclair argues that the animosity, dislike and 'hatred' toward Māori was

a permanent background to colonization in New Zealand, weaker at times, but always there and increasing for various reasons during the eighteen fifties. $^{166}$

It is important to point out that the Governor, who had direct oversight of Native Affairs and was therefore their greatest advocate in the Government, considered Māori to be savages that needed to give way to his more "civilised brethren". The members of Parliament appeared similarly predisposed to deny Māori their rights to retaining their land if they were to remain in communal ownership and considered that individual title could "elevate them above that communal system (or no system) of life which lies at the root of their present uncivilised state". ${ }^{167}$ These same men were also solely responsible for the drawing up of laws and agencies to effectively administer Māori affairs and Māori land and thereby determine the rules by which Māori could retain or lose their land.

By the 1860s, colonial officials and policy only protected Māori interests in so far as it aligned with colonial or imperial interests, but where those interests diverged, settler and colonial interests were to predominate. ${ }^{168}$ Settler interests were focused around profits and progress, not Māori rights or interests, and the longer Māori rights were upheld, the stronger the resentment and the quicker notions of racial superiority over Māori turned into racial prejudice. ${ }^{169}$ Keith Sinclair sums up the settler attitude by arguing that "in this simple conflict of interests, lay the seeds of the New Zealand war". 170

\footnotetext{
${ }^{164}$ Sinclair, Origins of Māori war, p.8.

165 Browne to Newcastle, p. 2

166 Sinclair, Origins of Māori war, p.10.

${ }^{167}$ William Fox to the Lord Bishop William Waiapu, 'Papers relative to Native Affairs', AJHR, Enclosure 3, No. 1, 4 July 1864, p.78.

${ }_{168}$ David Pearson, A Dream Deferred, Wellington, Allen \& Unwin, 1990, p.46.

${ }^{169}$ Sinclair, Origins of Māori war, p.11.

${ }^{170}$ Ibid, p.6.
} 
Sales of Māori land were stagnating as resistance to sales and the creation of the King Movement consolidated Māori sympathies (particularly in the Waikato) against the sale of Māori land. The outcome in Waikato was a forced occupation and confiscation of Māori land by invasion and then administrative processes, particularly through the establishment of the Native Land Court as will be seen in Chapter Four.

\section{The Waikato invasion}

The war in Waikato from a historical point of view is referred to as the Waikato War or part of the wider New Zealand Wars or Land Wars. ${ }^{171}$ For Waikato, it was an invasion given their efforts to stop armed hostilities had been exercised prior to 1863. Pōtatau and Tāwhiao had conveyed to their respective Governors that they had no desire to go to war. The efforts by Rangatira across the North Island in 1860 to 1862 were adamant that issues concerning land be conducted "according to law" and this stance continued up until the invasion by colonial forces at Mangatāwhiri. ${ }^{172}$ Thomas Smith's letter of 21 November 1863 advising the Native Minister that Waikato did not want to go to war, ${ }^{173}$ confirms that Waikato would remain peaceful unless attacked and Danny Keenan argues that the campaign by Cameron into the Waikato is "commonly and properly called" an invasion. ${ }^{174}$

\section{Kīngitanga}

The Waikato invasion was a result of conflicting interests between settlers, colonialists and Māori. ${ }^{175}$ Despite promises of equality and citizenship, Māori did not have the right of representation in Government until 1867 and promises made by Land Commissioners of enduring benefits for Māori when selling land, were often ignored or forgotten. ${ }^{176}$ William Martin argued that

Arrangements had been formerly made to provide for the future interests of the native sellers, and to give them some continuing benefit out of the

\footnotetext{
${ }^{171}$ See Sinclair, Origins of Maori War, Keenan, Wars without End, Cowan, New Zealand Wars, Belich, New Zealand Wars, Neville Ritchie, 'The Waikato War of 1863-64: A guide to the main events and sites', in Department of Conservation, ed., Department of Conservation, 2007.

${ }^{172}$ Thos. H Smith to Native Minister, The Civil Commissioner to the Honourable Native Minister, Papers relative to the Native Meeting at Peria, AJHR, Session I, E-No.12, 21 November 1863, p.22

${ }^{173}$ Smith, 'Civil Commissioner', p.22.

${ }^{174}$ Keenan, Wars without end, p.220

${ }^{175}$ Sinclair, Origins of Māori war, p.6.

${ }^{176}$ Martin, 'Proposal to take Native lands', p.9
} 
transfer of their lands. Even these, which should have been sources of attachment and confidence, became causes of irritation and distrust. ${ }^{177}$

Martin goes on to argue that the Crown, in its dealings with Māori, would have done well to protect the interests of Māori by seeking to secure their development, instead the Crown had focused to purchase land

on the pretence that you wanted land for the purpose of colonization [sic], without making provision (at least in the North Island) for their own improvement, you have at last brought the natives to believe that your real object is to impoverish and degrade them. ${ }^{178}$

The Colonists admitted to ignoring Māori interests from 1853 to 1862 by pursuing the goals of the colony and settler needs and by the time the invasion of the Waikato occurred, there was little to no faith in either the Crown or the colony. ${ }^{179}$ For Waikato, a meeting at Paetai on $23^{\text {rd }}$ April 1857, in the presence of the Governor, Pōtatau requested a magistrate, laws and a runanga as a means to uphold peace, law and order in the Waikato. ${ }^{180}$ This included in 1859 a letter signed by 400 names including Tâwhiao and Wiremu Tamehana, requesting a ban on the sale of alcohol in the Waikato. ${ }^{181}$ On both accounts (Paetai and the request to ban alcohol), the Governor agreed and although a magistrate was assigned to the Waikato the Magistrate, Francis Fenton, refused to visit villages that supported the Kingitanga. ${ }^{182}$ In the end, and on both accounts, there were no measures to assist the Kingitanga to maintain law and order in the Waikato.

The purpose of the Kīngitanga was not only as a measure to stop land sales, but also to bring law and order amongst Māori that the Crown and colony had failed to provide. ${ }^{183}$ David McCan argues that

The Kīngitanga was chartered to do three things: maintain Māori mana motuhake (a separate authority), hold the land that had...been placed under the mana of the King and stop intertribal warfare. ${ }^{184}$

\footnotetext{
${ }^{177}$ Martin, 'Proposal to take Native lands', p.9

${ }^{178}$ Fox, 'Proposal to take Native Lands', p.9.

${ }^{179}$ Martin, 'Proposal to take Native lands', p.9.

${ }^{180}$ Ibid, p. 11

181 Ibid.

182 McCan, Whatiwhatihoe, p.34.

${ }^{183}$ Ibid, p.32.
} 
For settlers, the Kingitanga solidified their inability to access more land and as a "land league", appeared to impede their continuing development and reject British sovereignty. For some sections of the colony, the Kingitanga was an act of treason and although there were more moderate sections of the colony, they considered the Kinngitanga divisive and threatening to the colony. ${ }^{185}$ In reality however, the Kinngitanga was not established to oppose the Government but as mentioned above, to protect Māori interests and the retention of Māori land. Governor Gore Browne in 1857 did not consider the Kingitanga a threat to the Crown and in a report to the Duke of Newcastle, Gore Browne conveyed that Pōtatau maintained his loyalty to the Queen and

desired to have a chief of their own election, who should protect them from every possible encroachment on their rights, and uphold such of their customs as they were disinclined to relinquish. ${ }^{186}$

Following the war in Taranaki however, and the Colonists' perception that Waikato had supported Taranaki, any goodwill between the Crown and Tāwhiao dissipated when a manifesto addressed to Waikato in 1861 demanded that Waikato

should make at once an unreserved surrender of all they had done for themselves and be content to receive in exchange vague reassurances of some good to be done for them hereafter by a power which had, up to that time, done next to nothing, and in whose promises they had ceased to trust. $^{187}$

The invasion was also about teaching the Kingitanga that they were subservient to the Queen and that the Kingitanga needed to be decisively defeated or eliminated. Since its inception, the Kingitanga had come into the government's focus, but was more so in 1861 when the Kinngitanga appeared to become more threatening and more effective in their ability to cease land sales. ${ }^{188}$ By fabricating hysteria that Waikato was about to invade Auckland, settlers and the colony were able to convince London that war was required and the funds to suppress rebellion was necessary. ${ }^{189}$ The Colonial Secretary,

\footnotetext{
${ }^{184}$ McCan, Whatiwhatihoe, p.32.

${ }^{185}$ Claudia Orange, The Treaty of Waitangi, Wellington, Allen \& Unwin, 1987, p.143.

${ }^{186}$ Martin, 'Proposal to take Native lands', p.11.

${ }^{187}$ Ibid, p. 12.

${ }^{188}$ Keenan, War without end, p.207.

${ }^{189}$ McCan, Whatiwhatihoe, p.46 and Keenan, War without end, p.215.
} 
William Fox, went so far as to convey to the Aboriginal Society on 4 May 1864 that Waikato had invaded Auckland by arguing that

the rebels...[at] the commencement of the present unhappy struggle...appear to have entertained a firm conviction that they could drive the Europeans out of the island and they commenced by a desperate attack upon Auckland, the seat of Government. ${ }^{190}$

In reality, there was no threat to Auckland and had that attack actually taken place, there is little likelihood that the invasion of the Waikato would have stopped at Ōākau, but carried on into the King Country where Tāwhiao was residing and the Kingitanga defeated or eliminated. Instead, once the colonial forces had pushed Waikato Māori out of the key productive areas, the war stopped and Tāwhiao was left relatively unmolested, suggesting then, that the invasion was about acquiring land and not decisively defeating the Kingitanga.

In 1860, settlers became even more dissatisfied with Māori once the war in Taranaki started and Māori in turn became equally dissatisfied with the Crown. Gore Browne called a conference at Kohimarama with 'friendly' Rangatira to supposedly clarify the terms of the Treaty of Waitangi, but in reality "to consolidate sovereignty by securing from the chiefs support for his actions as Waitara and condemnation of the King Movement". ${ }^{191}$ Gore Browne proclaimed that "[e]very Māori is a member of the British Nation; he is protected by the same law as his English fellow subject" while at the same time warning that the Crown's protection would only remain and Māori rights upheld, as long as Māori did not abrogate their allegiance to the Crown. ${ }^{192}$

For Waikato Māori, it did not have the impact Gore Browne may have been seeking. Instead, Tāwhiao was still mourning the death of his father, Pōtatau Te Wherowhero, on

\footnotetext{
${ }^{190}$ Fox to Aboringes Protection Society, 'Memorandum by Ministers in Reply to Aborigines Protection Society, enclosed in No.4', Papers relative to Native Policy including... Military Settlements, AJHR, Session I, E-No.2, 5 May 1864, p.18.

${ }^{191}$ Orange, Treaty, p.145. See also Bryan Gilling, 'Raupatu: the punitive confiscation of Māori land in the 1860s' in R Boast and R Hill, eds., Raupatu: the confiscation of Mãori land, Wellington, Victoria Unversity Press, 2009, p.17 regarding reference to 'friendly'.

${ }^{192}$ Orange, Treaty, p.145.
} 
25 June 1860, and whose tangi was delayed until 5 July so that Rangatira from all over the country could attend. ${ }^{193}$

By 1862, tensions and pressure to open up the Waikato became more persistent and at a meeting in Peria from 23 to 27 October and Ngāruawāhia on 10 November 1862, a number of Rangatira from across the North Island met to discuss the closing of the road at Mangatāwhiri and the Whaingaroa Harbour. Those present included Tāwhiao, Wiremu Tamehana, Hohaea Matata (of Whakatāne), Hoera te Titaha (Ngāti Porou), Paraone (Tauranga), Te Tauaroto (Ngāi te Ata), Wiremu (Waihoa), Kereopa te Rau (Rotorua), Raharuhi (Ngāti Awa), Wiremu Toatoa (Ngāti Kahungunu), Eparaima (Ngāti Porou), Pineaha (Ngāti Maru), Te Reweti te Mauotea (Ngāi te Rangi), Paora (Putatere), Tawati (Tauranga), Tawaha (Tauranga), Tamihana (Ngāti Awa), Perenara (Ngāti Awa), Hemi Matene (Tainui, Whaingaroa), Wiremu (Toetoe), Te Pakanga, Te Herewini Ngātiho (Kohekohe), Tioriori (Ngāti Haua), Pineaha (Hauraki), Wiremu te Raho (Pukaki), Karaitiana (Ngāti Kahungunu), Karaka, Tuhora, Matiu Wahapurua (Ngāti Maru), Ngairo (Ngāti Kahungunu), Paora Kaiwhata (Ngāti Kahungunu), Herewini Te Whahaete, Wirihana (Ngāti Kahungunu), Harawira (Ngāi te Rangi), Hohaia (Whakatane), Te Hira (Ngāti Hau) as well as around 300 supporters. ${ }^{194}$

At both meetings and previously on 1 November 1860, the "great Runanga" of Rangatira from across the North Island wrote to the Native Minister via Heta Tauranga to articulate the resolutions passed at that meeting. They were:

1. The road to Mangatāwhiri was not to continue

2. The road at Whaingaroa should not cross the Waitetuna

3. The steamer was not to enter the Waikato

4. Fighting over land was to cease and be adjudicated according to law

5. Credit for European goods was to cease, citing Romans, xiii.8. ${ }^{195}$

6. Europeans who are living amongst us must not be ill-treated, but taken care of. Those that conduct themselves badly will be sent back to Auckland.

\footnotetext{
${ }^{193}$ McCan, Whatiwhatihoe, p.36.

${ }^{194}$ Bishop Selwyn, 'Report on the meeting at Peria in October 1862, by Bishop Selwyn', Papers relative to the Native meeting at Peria in October 1862, AJHR, Session I, I-No.2, 23 October 1862, 1863, p.10.

${ }^{195}$ Fulfilling the Law through Love: Owe no one anything, except to love each other for the one who loves another has fulfilled the law - Romans, 13: 8 - The Holy Bible, English Standard Version, (2001), London: Crossway Bibles, p.1142.
} 
7. The Governor should appoint a day to meet with the Māori personally to allow both sides to speak to their intentions. If the conversation is good then the question of Waitara can be investigated. ${ }^{196}$

Piripi Matewha also wrote to the Governor conveying the same seven points above, noting the support of iwi from elsewhere including "nga iwi i tae mai ki taua huihuinga nei ko Porou ki Kahuhunu [sic] ko te Urewera ko te Atiawa". ${ }^{197}$ Those iwi listed by Matewha included:

Ko Ngaiterangi, Ko Ngātiwhakaue, Ko Ngātiaukawa, Ko Ngātipaoa, Ko Ngātiwhānaunga, Ko Waikato, Ko Ngātimahuta, Ko Ngātipou, Ko Ngātitametera, Ko te Ranehea, Ko Ngātimahanga, Ko Ngātihourua, Ko Ngātihikairo, Ko Ngātimaniapoto, Ko Ngātiapakura, Ko Ngātihinetu, Otiia he maha nga iwi ekore taea te tatou [sic]. ${ }^{198}$

A key component of Matewha's letter was that Europeans were to be "treated with kindness", but also that the road at Mangatāwhiri not be crossed and that the steamer not sail into the Waikato. ${ }^{199}$ By 1862, those iwi attending the Peria meeting were of the understanding that the Governor had stopped all sales of guns, lead and gun powder to Māori as a means of cutting off supplies of weapons so Māori did not attack settlers or the colonial army. ${ }^{200}$ As a measure of protection from the colonial army accessing them south of the Mangatāwhiri, iwi at Peria agreed to the closing of the road to Mangatāwhiri and the stopping of steamers in the Waikato, so that in turn, the Governor and his armies were unable to attack Māori. ${ }^{201}$ This is clearly spelt out in Hetaraka Nero's letter of 5 November 1862 where he convey's Wiremu Tamehana's message at Peria by stating that

\footnotetext{
${ }^{196}$ Heta Tauranga, 'Heta Tauranga to the Honourable the Native Minister', Papers relative to the Native meeting at Peria in October 1862, AJHR, Session I, E-No.2, 1 November 1862, 1863, p.19.

${ }^{197}$ Piripi Matewha, 'Piripi Matewha to his Excellency the Governor, Papers relative to the Native meeting at Peria in October 1862, AJHR, Session I, E-No.12, 3 November 1862, 1863, p. 20.

${ }^{198}$ Matewha 'Piripi Matewha', p.20 - Translated as "There were, however many others impossible to enumerate".

${ }^{199}$ Ibid.

${ }^{200}$ Selwyn, 'Report on the meeting at Peria', p.10.

${ }^{201}$ Hetaraka Nero, 'Hetaraka Nero to Mr Halse', Papers relative to the Native meeting at Peria in October 1862, AJHR, Session I, E-No.2, 5 November 1862, 1863, p.21. See also reference to Wiremu Tamehana in Major R.H McGregor, 'The Resident Magistrate, Raglan, to the Honourable the Native Minister', Papers relative to the Native meeting at Peria in October 1862, AJHR, Session I, E-No.12, 29 October 1862,1863, p. 18 .
} 
Wiremu Tamehana arose and said, "The Governor commenced the stopping; he stopped (the sale of) guns, powder, and lead; the object of his stopping (these things) was lest the Maoris [sic] should get guns and turn upon him, and my object in stopping the roads is that the Pakehas [sic] may not have access to me to attack me. This is why I stop the roads." 202

There is no mistake that the Native Minister was aware of peaceful overtures by the Kinngitanga and supporting iwi, given the Civil Commissioner at Maketū wrote to the Native Minister to convey this message. The Civil Commissioner, Thomas H Smith, wrote that

a majority [of iwi] being unfavourable to a renewal of hostilities, it was formally announced by [Wiremu Tamehana], as the decision of the people, that peace should be preserved until the Governor should become the aggressor, on which all acknowledging the Māori King would rise in arms. He added that he would leave it for some other tribe to begin a quarrel with the pakeha, as having set up a King for the island, he thought he had done his share of the work, and would rest content with that $[\mathrm{sic}] .{ }^{203}$

Despite these overtures of peace, there remained a sense of panic in Auckland that the Kingitanga was going to attack. ${ }^{204}$ Although Gore Browne conveyed that the threat of attack by Waikato was baseless to the Superintendent in Auckland, the growing prejudice toward Māori continued, resulting in "friendly natives" being accosted in Auckland. ${ }^{205}$ However, although Gore Browne had been given every assurance that the Kingitanga was to remain peaceful unless provoked, Gore Browne continued to fortify Auckland and engage settlers and friendly Māori into units of voluntary calvary regiments ${ }^{206}$ and thereby maintaining the fiction that an attack was imminent.

This fallacy of an attack on Auckland was maintained throughout the Waikato invasion. In 1864, Charles Heaphy a volunteer Major in the Armed Constabulary that invaded the Waikato, also referred to an actual attack on Auckland as the cause for hostilities in the Waikato. Heaphy refused the idea that it was because of "white people dispossessing

\footnotetext{
${ }^{202}$ Nero, 'Hetaraka Nero', p.21.

${ }^{203}$ Smith, 'Civil Commissioner', p. 22.

${ }^{204}$ Keenan, War without end, p.214.

${ }^{205}$ Ibid, p. 215.

206 ibid, p. 216.
} 
them of their lands [or] by the existence of an actual pressure arising out of the spread of colonization". 207

Charles Heaphy, prior to the Waikato invasion, was part of the survey works on the military road to Mangatāwhiri, as well as charting channels down the Waikato river and an "enthusiastic propagandist" of the Taranaki and Waikato wars. ${ }^{208}$ At the time of writing his Memorandum to both Houses of the General Assembly (as commanded by the Governor) Heaphy had already taken part in intense fighting with Māori, including an effort to save one of his troops, resulting in the Victoria Cross, the first colonial New Zealander to be granted the award. ${ }^{209}$ Despite those heroics however, Heaphy continued the propaganda that the war in the Waikato was justifiable because land sales in the Waikato had ceased.

The invasion of Waikato began when the Crown's soldiers crossed the aukati, Tāwhiao's established northern boundary, at Mangatāwhiri on 12 July 1863. In doing so the Crown invaded the Waikato with the intent of going to war with Tāwhiao and the Waikato people. ${ }^{210}$ A Tainui historian, Moko Tauariki, during a gathering at Rangiriri argues that the "war" was an invasion and Waikato today are still aggrieved by that invasion. $^{211}$ By the Government's own admission, in 1995 they enacted legislation confirming that the Crown invaded the Waikato by crossing the Mangatāwhiri. That legislation states:

D The New Zealand Government at the time perceived the Kīngitanga as a challenge to the Queen's sovereignty and as a hindrance to Government land purchase policies...

E In July 1863, after considered preparations by the New Zealand Government, military forces of the Crown unjustly invaded the Waikato

\footnotetext{
${ }^{207}$ Charles Heaphy, 'Memorandum by Charles Heaphy, CE. on the Native question', $A J H R$, Session I, E09, 17 November 1861, 1864, p.2.

${ }^{208}$ Michael Fitzgerald, "Heaphy, Charles $1820-1881 "$. Dictionary of New Zealand Biography. Ministry for Culture and Heritage. Retrieved 2 June 2013.

${ }^{209}$ Fitzgerald, 'Heaphy, Charles'.

${ }^{210}$ Waikato Raupatu Claims Settlement Act 1995

${ }^{211}$ Moko Tauariki, Presentation, 19 October 2013, Rangiriri Pā.
} 
south of the Mangatāwhiri river, initiating hostilities against the Kīngitanga and the people. ${ }^{212}$

The first military encounter between the Crown and Waikato occurred at Te Koheroa on the $17^{\text {th }}$ of July, which was won by the Crown, before moving on to Meremere where on 12 August, the gunboat Avon incapacitated the pā site by bombing the pā and those residing within. ${ }^{213}$ The major battle however began on 18 November at Rangiriri where Tāwhiao and Ngāti Hine fought side by side. ${ }^{214}$ The man-made trenches built at Rangiriri stretched from the Waikato River to Lake Waikare, over one kilometre long, east to west, involving a

double ditch and high parapet...[as well as] an entrenched line of rifle pits parallel to the Waikato river. ${ }^{215}$

At 3.00pm, Tāwhiao and his followers were fired upon by two 12-pounder cannons and two gun boats (the Pioneer and the Avon) on the Waikato River, before being attacked two hours later by foot troops that included the $40^{\text {th }}$ and $65^{\text {th }}$ Regiment, the Royal Artillery and seamen from the Royal Navy. ${ }^{216}$ The first attempt by Crown forces to storm the Rangiriri pā failed and after stranded troops on the Pioneer and Avon were able to land, the colonial army cut off reinforcements to the pā. Two more attempts to take control of the pā also failed. ${ }^{217}$ At dawn Waikato raised a white flag requesting parley to exchange terms or call a truce, however during parley Cameron attacked Waikato and forcibly took 183 prisoners. ${ }^{218}$ McCan argues that

British troops took advantage of the truce, poured into the Māori trenches and demanded the surrender of arms...Cameron's dishonourable transgression of the rules of war was for a long time recorded in New Zealand history as the unconditional surrender of Māori. ${ }^{219}$

\footnotetext{
${ }^{212}$ Waikato Raupatu Claims Settlement Act 1995, Section D and E.

${ }^{213}$ Keenan, War without end, p.222.

${ }^{214}$ Belich, New Zealand Wars, p.144.

${ }^{215}$ D.A Cameron, 'Lieut-General Cameron, C.B., to his Excellency the Governor', Further Papers relative to the Native Insurrection, AJHR, Session I, E-05a, 24 November, 1863, p.4.

${ }^{216}$ Cameron, 'Lieut-General', p.4 and Keenan, War without end, p.223.

${ }^{217}$ Keenan, War without end, p.223.

${ }^{218}$ Cameron, 'Lieut-General', p.3.

${ }^{219}$ McCan, Whatiwhatihoe, p.47.
} 
The remaining Waikato forces including Tāwhiao, escaped the night before by swimming across a swamp at Lake Waikare. ${ }^{220}$ Those Waikato that died at Rangiriri were killed by gunfire, cannon fire, and drowning while trying to escape, the latter of whom were mainly women, with their children wrapped around them, who had been gunpowder runners in the Rangiriri trenches. ${ }^{221}$ In Waikato's version of events, many Waikato escapees from Rangiriri were hunted down after parlay and shot so as not to fall back to Waikato positions further up the River. ${ }^{222}$ Most of those captured and killed were unarmed, however those who survived had taken "refuge in the swamps and lakes to the east of the defence lines of Rangiriri". 223

As mentioned previously, redoubts were established to cut off further support and trade to Auckland, pushing Kinngitanga supporters further south. The invasion went on to Ngāruawāhia, Pāterangi, Rangiaowhia and ended finally at the battle of Ōrākau on 2 April 1864. The colonial army had not decisively beaten the Kingitanga forces but rather, were unwilling to pursue Tāwhiao and his followers any further. ${ }^{224}$ Had the Crown's reason for invasion been to crush the Kingitanga, it seems more likely that they would have followed Tāwhiao into the King Country.

For Waikato then the invasion was simply a land grab. Having supposedly won the war in Waikato, the colonial government then implemented a series of processes to expedite the dispossession of Māori land and an aggressive confiscation policy and practice allowing for significant settlement in the Waikato region by ex-militia and emigrants.

\section{Confiscation}

Inherent in the notion of colonisation is the premise that the colonial power has the authority to confiscate land, including sovereignty over the land, and has the authority to provide grants to its settlers or other eligible people. Indigenous peoples who were in possession of their land were assumed by the colonial power to have either ceded their lands or those lands were taken through the process of colonisation for settlement or

\footnotetext{
${ }^{220}$ Cameron, 'Lieut-General', p.3.

${ }^{221}$ Moko Tauariki, Presentation, 19 October 2013, Rangiriri Pā and Tom Roa in Hineani Melbourne, 'Rangiriri - The 150th Anniversary of the Land Wars in Waikato, Waka Huia, Auckland, TVNZ, 4 May 2014, 11min.

222 Ibid.

${ }^{223}$ Turongo House, Tāwhiao, p.59.

${ }^{224}$ Keenan, War without end, p.230.
} 
economic expansion. ${ }^{225}$ Once the colonial power had ownership of the lands within its borders, it was then an expectation that those holding titles from the colonial power owed or swore fealty as a condition of maintaining those titles. Indigenous peoples, who resisted cession or the purchase of their lands, had their lands confiscated either for treason or for a failure to productively utilise their land. ${ }^{226}$

Both treason and a lack of productivity were deemed by the Crown to be in existence in Waikato, and as a result, a process of confiscation was undertaken. Confiscation in the nineteenth-century was an act where land was taken for acts that a ruling body deemed to be of rebellion or treason. ${ }^{227}$ It is linked by Bryan Gilling with British colonisation in the 1700-1800s and its application in Ireland in the 1600s, and Imperial Rome which included not only confiscation of land and the death of rebels, but also "damnation of memory" where an alleged traitor's children were executed as they were deemed corrupted by blood. $^{228}$ In the Middle Ages, King Alfred the Great (of Wessex) and King Canute (of England and Denmark in 1018) also defined crimes against the monarch as high treason resulting in confiscation. ${ }^{229}$ In 1351, confiscation, as forfeiture, was legalised by Edward III, in his Statute of Treason (Treason Act 1351) whereby crimes against the Crown also allowed for forfeiture of land. ${ }^{230}$ The Act states that

Offences shall be adjudged treason...if a Man do levy war against our Lord the King in his Realm, or be adherent to the King's Enemies in his Realm, giving to them Aid and Comfort in the Realm, or elsewhere. ${ }^{231}$

The forfeiture of land by treason has as its foundation the notion that land, as an estate, is granted by the Crown and any break with the Crown or acts of treason, will therefore

\footnotetext{
${ }^{225}$ See Michael Allen, 'An Illusory Power? Metropole, Colony and Land Confiscation in New Zealand, 1863-1865', in Richard Boast and Richard Hill, eds., Raupatu: The Confiscation of Maori Land, Wellington, Victoria University Press, 2009.

${ }^{226}$ Robert Young, Postcolonialism, Oxford, Blackwell Publishers, 2001.

${ }^{227}$ Bryan Gilling, 'Raupatu; the Punitive Confiscation of Māori land in the 1860s', in Richard Boast and Richard Hill, eds., Raupatu: The Confiscation of Māori Land, Wellington, Victoria University Press, 2009, p. 14.

${ }^{228}$ Ibid.

${ }^{229}$ Ibid.

${ }^{230}$ Desmond Keenan, Ireland 1170-1509, Society and History, Bloomington, Xlibris, 2010, p.475.

${ }^{231}$ Treason Act 1351, Section II
} 
result in the Crown taking back its estates through forfeiture. ${ }^{232}$ Those whose lands were forfeited were often labelled rebels while those supporting the Crown considered loyal.

The labelling of Indigenous peoples as either loyal or rebel occurred in other colonies outside New Zealand including Ireland, Scotland and the Cape Colony and relied on an arrangement whereby loyalists were able to keep those lands that belonged to them after general confiscation occurred. ${ }^{233}$ In reality however, loyalists' land was also often confiscated and although land originally owned by them was returned, in some instances, they were given lands elsewhere and were often the best of the unwanted lands confiscated. ${ }^{234}$

Rebels were seldom returned land, particularly land they previously owned or certainly not in the amounts previously owned. ${ }^{235}$ A key reason for this was to ensure that rebels were incapable of further uprisings in the future and that the economic base upon which their rebellion relied, was eliminated. This was a vital practice throughout confiscation: the inability for future rebellion.

The deliberate labelling of rebels ensured that this group was easily identifiable and often created an ongoing stigma based on their resistance to the Crown. In the New Zealand experience, settlement claims by Māori for past confiscation, have often focused on whether the confiscation of their land was justifiable based on the tribe's loyalty or rebellion against the Crown. ${ }^{236}$ Those in rebellion argue an unjust invasion and consequent confiscation, and those loyal to the Crown often argue unfair confiscation based on their loyalty, both of which received far less land than promised following the war.

\footnotetext{
${ }^{232}$ Richard Boast, “An expensive mistake': Law Courts and Confiscation on the New Zealand Colonial Frontier', in P.G Hugh, Richard Boast and Mark Hickford, eds., Law and Confiscation: Essays on Raupatu in New Zealand History, Number 14, Wellington, Treaty of Waitangi Research Unit, 2009, p.16. ${ }^{233}$ See Brigid Kelly, 'The alienation of land in Ireland and in Aotearoa/New Zealand under English colonisation', Auckland University Law Review, 9, 4, 2003; William Butler, Confiscation in Irish History, Dublin, The Talbot Press, 1917; Leonard Guelke, 'The anatomy of a colonial settler population: Cape Colony 1657-1750', The International Journal of African Historical Studies, 21, 3, 1988; Boast and Hill, 'Overview', 2009.

${ }^{234}$ Ibid.

${ }^{235}$ Moko Tauariki, Presentation, 19 October 2013, Rangiriri Pa.

${ }^{236}$ Waikato Raupatu Claims Settlement Act 1995; Ngati Awa Claims Settlement Act 2005; Ngāti Tuwharetoa (Bay of Plenty) Claims Settlement Act 2005; Ngati Ruanui Claims Settlement Act 2003; Ngā Rauru Kiitahi Claims Settlement Act 2004; Ngati Mutunga Claims Settlement Act 2006.
} 


\section{Confiscation in Waikato}

Waikato confiscations were a direct consequence of the invasion of Waikato and the resistance by the Kingitanga and their supporters. There is however evidence that suggests that Governor Grey had been contemplating confiscation before the outbreak of the war in Waikato. On the $24^{\text {th }}$ of June 1863 , Domett wrote to the Governor outlining the means by which Waikato could be invaded, military redoubts established, settlements put in place and Māori land confiscated to allow for settlement. Domett argues that

The plan...is to make the Waikato river, from the sea on the West Coast to its Southern bend in the middle of the island, a temporary line of defence, by placing armed steamers on the river, and by establishing posts on its northern bank. Then from the bend of the river to establish a line of military posts, extending to the Hauraki Gulf...Next to throw forward military posts from the central bend of the river up to Paetai and Ngāruawāhia, taking permanent possession of those places...At the same time to clear out all hostile Natives at present residing between the Auckland Isthmus, and the line of the River and fortified posts first above mentioned, which together cross the island. Lastly to confiscate the lands of the hostile Natives, part of which lands would be given away and settled on military tenure to provide for the future security of the districts nearer Auckland, and the remainder sold to defray the expenses of the invasion. ${ }^{237}$

For the Colonial Secretary, William Fox, Waikato in the 1860s "has been and is the head of the rebellion, and the neck of it must be broken there" to ensure the "final, permanent and complete subjugation of Waikato". ${ }^{238}$ Fox believed that Māori owned more land than was good for them and that it was in their best interests that the confiscation scheme be undertaken. ${ }^{239}$ William Fox argued that

\footnotetext{
${ }^{237}$ Alfred Domett, 'Memorandum for the Governor', Colonial Responsibility in Native Affairs, $A J H R$, Session I, E-No. 7, 24 June, 1863, p.8.

${ }^{238}$ Fox, 'Reply to Aborigines Protection Society', p.19.

${ }^{239}$ Ibid, p.24.
} 
Ministers believed that nothing has been or can more pernicious to the Native race than the possession of large territories under tribal titles which they neither use, know how to use, nor can be induced to use. ${ }^{240}$

Confiscation in Waikato resulted in 1.2 million acres taken out of Māori ownership causing displacement, economic deterioration and those of Ngāti Hine descent in Waikare to be placed in native reservations or land blocks with little immediate means of survival.

The New Zealand Settlements Act 1863, Suppression of Rebellion Act 1863 (which gave the military authority to repel or crush a rebellion) and the New Zealand Loans Act 1863 (which sought to raise a loan from England that was secured against sales of future confiscated lands) facilitated the confiscation in Waikato. ${ }^{241}$

\section{New Zealand Settlements Act}

The New Zealand Settlements Act was an Act to "enable the Governor to establish Settlements for Colonization in the Northern Island of New Zealand."242 Section 2 of the Act allowed for the taking of Māori land from those tribes or sections of tribes that had been engaged in rebellion against the Crown. Section 5, which included the types of behaviours that resulted in confiscation, states that:

(1) Who shall since the $1^{\text {st }}$ January 1863 have been engaged in levying or making war or carrying arms against Her Majesty the Queen or Her Majesty's Forces in New Zealand or -

(2) Who shall have adhered to aided assisted or comforted any such persons as aforesaid or -

(3) Who shall have counselled advised induced enticed persuaded or conspired with any person to make or levy war against Her Majesty or to carry arms against Her Majesty' Forces in New Zealand or to join with or assist any such persons as are before mentioned in Sub-Sections (1) and (2) or -

\footnotetext{
${ }^{240}$ Fox, 'Reply to Aborigines Protection Society', p.20.

${ }^{241}$ Gilling, 'Punitive confiscation', p. 17.

${ }^{242}$ Preamble to the New Zealand Settlements Act 1863.
} 
(4) Who in furtherance or in execution of the designs of any such persons as aforesaid shall have been either as principal or accessory concerned in any outrage against person or property or -

(5) Who on being required by the Governor by proclamation to that effect in the Government Gazette to deliver up the arms in their possession shall refuse or neglect to comply with such demand after a certain day to be specified in such proclamation. $^{243}$

These criteria made it difficult for Waikato Māori to comply given in some form or another, Waikato Māori were caught up in the invasion and therefore at war or assisted those at war. The Kingitanga had advocated peace and despite all their efforts, the Crown invaded the Waikato. Waikato Māori became engaged in the invasion whether by direct involvement as part of the hostilities, or indirectly as members of the wider whānau and hapū fed or housed those caught up in the fighting. Those who fell under section 5(3), also technically included those Rangatira who gathered at Peria and Ngāruawāhia in support of the Kīngitanga.

The process for confiscating land under the New Zealand Settlements Act was four fold. It firstly required a Proclamation from the Governor outlining the District that was to be taken, secondly eligible sites for settlement, thirdly the actual taking of the land for settlement and lastly compensation to those affected by the confiscation, other than those in rebellion against the Crown. ${ }^{244}$ There were no restriction to the areas that could be confiscated under the Act which could be seen in the proclamations issued by the Crown on 17 December 1864 with regard to Waikato, through to the Mohaka-Waikare District on 12 January $1867 .^{245}$

The New Zealand Settlement Act allowed the means by which the Crown could make land available for existing settlers and those arriving in New Zealand. A key factor to support confiscation under the New Zealand Settlement Act was to ensure that peace and order could be maintained in the colony. This would be accomplished by

\footnotetext{
${ }^{243}$ New Zealand Settlements Act 1863, see also Aroha Harris, 'Crown Acquisition of Confiscated and Māori Land in Taranaki, 1872-81', Wellington, Waitangi Tribunal Division, Department of Justice, 1993, p.1.

${ }^{244}$ Boast, 'An expensive msitake', p.26.

${ }^{245}$ Ibid, pp.27-28.
} 
developing military settlements within the Waikato culminating in a 'frontier' line. ${ }^{246}$ The Domett government saw confiscation as a vital warning to other tribes as defeat in war alone would be forgotten by Māori given, Domett believed, that they were influenced by "the vanity natural to barbarians". ${ }^{247}$ Domett's frontier line would involve roads into the Waikato that could be utilised by the colony's standing army and military settlements that

would overawe the Native Tribes, or if not overawe them, at least be always ready and able to check or punish their incursions and depredations. ${ }^{248}$

In line with the New Zealand Settlements Act and Domett's frontier policy, the Waikato was to have not only military settlers moved into the area, but also 10,000 immigrants to support public works projects such as rail and road, and to take up farming to support the colony. ${ }^{249}$ To allow this to happen, the Crown sought to provide settlers with 50 acres each, with 500,000 acres set aside in the Waikato. ${ }^{250}$ In contrast, 100 acres per adult Māori was set aside, with a limit of 4,000 'Rebel' Māori to be identified in Waikato. ${ }^{251}$ In reality, 'Rebel' Māori were granted significantly less than 100 acres per person. The 198 rebels granted land in Lot 512 shared only 387 acres between them, which was less than 2 acres per person. This was also the case in Lot 442 where 28 owners were given 9.4 acres each; Lot 393 with 64 owners receiving 10.3 acres each; Lot 213 with 10 owners receiving 10 acres each; and Lot 335 with 10 owners receiving 6.7acres. ${ }^{252}$ Those grantees that received larger land portions were in Lot 277 with 30 acres allocated to one owner and Lot 473 with 11 owners receiving 40 acres each. In the main however, 'Rebel' Māori in the Waikato did not receive the promised 100 acres per person.

Of the 400,000 acres that was to be returned, the land area within the Parish of Whangamarino accounted for approximately 95,776 acres that was confiscated in its

\footnotetext{
${ }^{246}$ Michael Allen, 'An Illusory Power?', p.119.

${ }^{247}$ Alfred Domett, 'Memorandum on roads and military settlements in the Northern Island of New Zealand', AJHR, Session I, A-8a, 5 October 1863, p.1.

${ }^{248}$ Domett, 'Roads and military settlements', p.1.

${ }^{249}$ Shirley M Morton, The Confiscation of the "Northern Blocks" of the Waikato and their Settlement by assisted migrants, Doctoral Dissertation, Auckland University College, 1946, pp.15-6. See also Allen,

'An Illusory Power', p.121.

${ }^{250}$ Allen, 'An Illusory Power', p.121.

251 Ibid.

${ }^{252}$ Māori Land Court block files for Lots 213, 335, 393, 442 and 512, Hamilton Office.
} 
entirety following the Waikato invasion. Within the Parish, 6,663 acres were returned to Māori with 4,073 acres provided to rebels.

The Colonial Secretary, William Fox, gives an outline of the intention of the New Zealand Settlements Act during a Parliamentary sitting in 1863 by arguing that

In order to establish the population which the Government intends to introduce, it is absolutely essential that it should have the land on which to establish them... What is required is a large population, practically outnumbering that of the Natives in those districts where rebellion exists, or may exist, to be permanently settled, with ownership of the land, so that they may not only have an interest, but the ability, to defend their homes from future aggression; and to effect this the Government looks to the lands of those tribes who have been in rebellion. ${ }^{253}$

Fox goes on to argue that

There is no injustice in taking the lands of such tribes, not by way of punishment, or of reducing the tribes from the position they now hold, but simply as a substantial guarantee, for the future peace and consolidation of the colony. This Bill provides for that object. ${ }^{254}$

The irony of Fox's statement is that authority is given for settlers to defend their interests and their lands from "Native" aggression, but the reverse is not granted. As was argued previously in this chapter, any economically powerful position of Māori in society, particularly in Waikato with the Kingitanga, appeared unacceptable to the Crown and the settlers, particularly those Māori who refused to sell land. Should Māori refuse to sell then Fox believed that war was the means by which the "future peace and consolidation of the colony" could be secured. ${ }^{255}$ This last statement is important. It is clear from this statement that for Fox, Māori did not fit into the colony and that the invasion to take land from Waikato Māori and give it to settlers was for the future prospects of the colony - not Māori. This suggest that Māori were not part of the

\footnotetext{
${ }^{253}$ William Fox, 'New Zealand Settlement Act in New Zealand Parliamentary Debates, 1861-1863, p.783.

${ }^{254}$ Ibid.

${ }^{255}$ Ibid.
} 
colony. The image of the colony was English, not Māori and there is little doubt then, that the colony excluded Waikato Māori.

However, the terms of confiscation were fraught with dissenting views between Governor Grey and the colonial government between 1863-1864. The points of dissention was around the area to be confiscated and the handing in of arms. Grey resisted confirming a Proclamation to Māori that surrendered (or returned) rebels give up their arms as, in Grey's estimation the great majority had no arms to give over and more importantly, this left Waikato Māori without any means of defending themselves or their lands left to them. ${ }^{256}$ Although there was little impetus for Waikato Māori to be armed following the war, Waikato Māori were left vulnerable against unsolicited attacks by Pākehā in their vicinity. Grey argued that rebels could be issued gun licenses to protect themselves but this was rejected by Whitaker who argued that any "Natives who return to reside in districts approved of by the government, should neither carry nor possess arms" and that the issuing of gun licenses to allow them to do so, was "out of the question". 257 The colonial Ministers considered Māori who remained armed as a danger to law and order, arguing that they could re-engage in rebellion should they disagree with the government at any time. ${ }^{258}$

With regard to the area of land to be confiscated, there remained further friction between Grey and his Ministers as well as opposition from the House of Commons. ${ }^{259}$ Although Grey and Whitaker agreed that land needed to be confiscated, they disagreed on how that land was to be quantified and where it was located. Grey sought to have Parliament draw up a map with the size and area that was to be taken so that Māori could gauge for themselves what this meant for them. Grey bemoaned Whitaker and his Ministers' vagueness by stating that

I repeatedly pressed the necessity of their at once telling me their intentions regarding the confiscation of Native lands and the necessity also of letting

\footnotetext{
${ }^{256}$ George Grey, 'Memorandum by the Governor as to proposed Terms to Rebel Natives', Papers relative to Native Affairs, AJHR, Session I, E-No2, 3 May 1864, p.37.

${ }^{257}$ Frederick Whitaker, 'Memorandum by Ministers as to proposed Terms to Rebel Natives', Papers relative to Native Affairs, $A J H R$, Session I, E-No.2, 3 May 1864, p.37.

258 Ibid.

${ }^{259}$ Boast, 'An expensive mistake', p.25.
} 
the natives know their true position in this respect and what was to be taken from them. They repeatedly declined. ${ }^{260}$

Whitaker considered that all lands belonging to the rebels were to be confiscated, from Raglan or Kāwhia across to Tauranga, then north to Auckland ${ }^{261}$ or alternatively, as was needed in the future. Whitaker argued that the only means by which Māori could survive the invasion was by "their full acknowledgement of their mistake, their full acceptance of its consequences, and submission to the supremacy of law". ${ }^{262}$

\section{Map 3: Area confiscated in the Waikato under the New Zealand Settlements Act $1863{ }^{263}$}

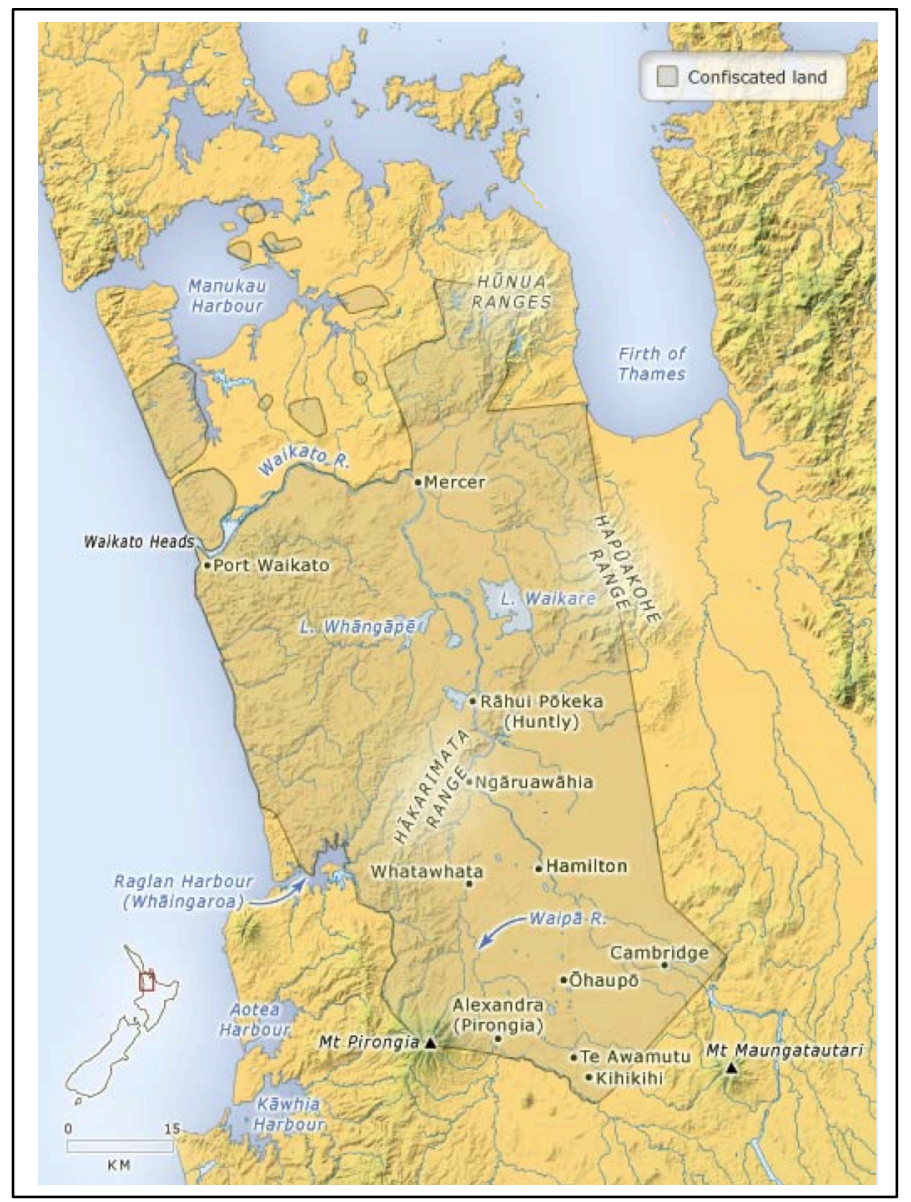

The Area confiscated included the Hunua Ranges across to Drury, down to Mercer and over to Port Waikato, down to Raglan on the Coast then down to Pirongia, across to

\footnotetext{
${ }^{260}$ George Grey, 'Enclosure 2 to No.11', Papers relative to Native Affairs, AJHR, Session I, E-No.2, 28 May 1864, p.58.

${ }^{261}$ Frederick Whitaker, 'Proposed Terms to Rebel Natives', p.58.

${ }^{262}$ Fox, 'Reply to Aborigines Protection Society', p.18.

${ }^{263}$ From http://www.teara.govt.nz/en/map/27791/confiscation-of-Māori-land. Downloaded on 29 October 2013 .
} 
Rangiaowhia and Cambridge and then following a line up to Pūkorokoro in Hauraki. Map 3 provides an outline of the confiscated area.

William Martin summed up the colonisation and confiscation experience in Waikato by summarising its events to some key points. Although Waikato had conveyed in all possible ways that they had no intention of going to war with the colony or the Crown, Waikato was still invaded and as a result, Waikato from their perspective was "deem[ed] an invasion". ${ }^{264}$ Martin argues that

It should be remembered that the proclamation announcing the purpose of the Government in entering their land, came after the entry of the troops on their land; and that even when it came, there was much in the claim it put forth, namely a claim to take such land as the Government might choose, without any mention of quantity or compensation, which was likely to alarm and excite them. ${ }^{265}$

Confiscation was, on the whole, applied successfully for the Crown in New Zealand and on analysis, there are five key aspects that underpinned its implementation: legislation, conflict, tenurial revolution, concept of waste land, settlement and economic expansion. These five aspects will be explored briefly with the view to applying them against the Case Study in Chapter Five.

\section{Common aspects of confiscation}

Legislation was required to effect confiscation and legitimise Crown acquisition of Māori land. Legislation was also enacted to provide the government with the authority to confiscate land owned by others. In New Zealand, Parliament passed the New Zealand Settlements Act, the Suppression of Rebellion Act and the New Zealand Loan Act. All three provided the basis for acquiring land for the settlement of existing settlers and emigrants, farmers or those that could economically advance the colony or nation.

Confiscation also followed a conflict between parties which were generally over authority or land. The premise for conflict was based on one party exerting its

\footnotetext{
${ }^{264}$ Martin, 'Proposal to take Native lands', p.14.

${ }^{265}$ Ibid.
} 
influence over those who had ownership or rights over land who refused to depart from that ownership. In Waikato, this conflict involved the Crown, settlers and Māori land owners. This aspect is important as it also relates to conflicts of interests which can be manifested either as armed conflict as was seen in the invasion of the Waikato, or legislatively, as was seen in the legislation listed above whereby land was legislatively acquired for the purpose of settlement, against those who owned it at the time.

Another aspect of confiscation is tenurial revolution of land ownership from traditional communal ownership to land grants derived from the Crown. Confiscation was the quickest method by which to acquire indigenous land upon which land ownership was changed out of communal ownership into individual grants. These grants were returned to Māori individuals through confirmation in the Native Land Court, as Māori freehold land. ${ }^{266}$ As individualised freehold title, these grants were then more easily brought and sold to third parties.

The Crown grant system was more easily understood by settlers and government Ministers. Any land remaining for Māori use required a system of title investigation that involved individualisation of title so that land could be leased or later sold to settlers as required. ${ }^{267}$ According to Richard Boast, and as will be discussed in more depth in Chapter Four, there was little difference between tenurial revolution and confiscation, but rather a different means of achieving the same ends. Boast argues that

There is in fact no sharp line between 'confiscation' and 'title investigation'; the former was land-taking, certainly, but it was also a fast-track version of the latter. ${ }^{268}$

In a stronger statement, Boast goes on to argue that

The legislature that enacted the legislation....reflected settler opinion; this community wanted to get its hands on coveted Māori-owned land in Taranaki and Waikato, and passed 'laws' to facilitate that aspiration. When it all turned out to be too difficult to carry through, other approaches were

\footnotetext{
${ }^{266}$ Boast, 'An expensive mistake', p.41.

267 Ibid.

${ }^{268}$ Ibid, p.42.
} 
utilised instead - although the general goals, acquisition of Māori land and its settlement by British Isles immigrants... were never lost sight of. ${ }^{269}$

Boast sums up tenurial revolution and its relatedness to confiscation by pointing out that statutory confiscation was a process of taking land off Māori, vesting it in the Crown before granting it, either back to Māori or to settlers. ${ }^{270}$ This was done through the passing of the New Zealand Settlement Act, but also through its "main vehicle", the Native Land Court and its legislating Act - the Native Land Acts, 1865. This is an important point and one that will be covered in Chapter Four and Chapter Five, but what Boast suggests, is that confiscation was not just limited to the New Zealand Settlements Act and the Proclamations issued as part of that confiscation process, but also, that confiscation through the Native Land Acts and the Native Land Court (and he touches on the Foreshore and Seabed Act of 2003 as a contemporary example), is also confiscation. $^{271}$

Another key aspect of confiscation was the labelling of perceived idle land as waste land. As was mentioned earlier in this chapter, any land not actually occupied or cultivated by Māori was considered waste. Areas that were utilised by Māori seasonally or for hunting and gathering did not fall within the Lockean idea of productive use, or Fox's idea of use. The colony considered the acquisition of waste land as a type of confiscation and listed it as such in 1871 when data showing how much land was acquired under the New Zealand Settlements Act and also as waste land for £1, 10 shillings or a penny an acre (see Table 3 ). Table 3 shows those lands considered to have been confiscated under any Acts of the General Assembly. ${ }^{272}$

This table suggests that land acquired from Māori at a price far less than land sold in an open market, is also considered confiscated land. At the time this table was drawn up, 894,553 acres under the Auckland province was confiscated, which encompassed the Parish of Whangamarino, where the case study for this thesis is located. The 749,061 acres acquired as waste land in the region is a significant area given the difference between land acquired under outright confiscation through the New Zealand Settlements

\footnotetext{
${ }^{269}$ Ibid, p.43.

${ }^{270}$ Ibid, p.41.

${ }^{271}$ Ibid, pp.41-43.

${ }^{272}$ M. McGillivary, 'Return of the Crown Lands in each Province showing the extent acquired by Confiscation', AJHR, Session I, C-04a, 17 August 1871.
} 
Act and those lands acquired as waste land differed by 145,492. These numbers suggest that land the Crown acquired as waste land is almost commensurate with forcible confiscation. It also suggests that declaring land as waste was as effective as going to war and confiscating it.

Another aspect of confiscation is land for settlement for existing and newly arriving settlers. This was a predominant driver for newly formed colonies. As the basis upon which an economic platform can be developed, the need to acquire and then develop land was an intrinsic part of settlement. Those immigrants that were sent to newly formed colonies were often from the lower to middle class parts of society who had little or no possibility of climbing up the social ladder in their home countries. Emigration to a new colony provided immigrants an opportunity to acquire land

Table 3: Return showing the acreage of land held by the Crown through Confiscation

\begin{tabular}{|l|lll|lll|lll|}
\hline \multicolumn{1}{|c|}{ Province } & \multicolumn{2}{|c|}{ Provincial Waste Lands } & \multicolumn{4}{c|}{ Confiscated Land } & \multicolumn{3}{c|}{ Total } \\
\hline \multirow{2}{*}{ Auckland } & A. & R. & P. & A. & R. & P. & A. & R. P. \\
\hline Taranaki & 749,061 & 2 & 2 & 894,553 & 1 & 39 & $1,643,615$ & 0 & 1 \\
\hline Hawke's Bay & 11,000 & 0 & 0 & 612,992 & 0 & 13 & 623,992 & 0 & 13 \\
\hline Wellington & 787,400 & 0 & 0 & 39,633 & 0 & 0 & 827,033 & 0 & 0 \\
\hline Nelson & $1,180,000$ & & 33,000 & 0 & 0 & $1,213,000$ & 0 & 0 \\
\hline Marlborough & $6,196,986$ & 2 & 29 & & & & $6,196,986$ & 2 & 29 \\
\hline Canterbury & $2,486,970$ & 1 & 2 & & & & $2,486,970$ & 1 & 2 \\
\hline Westland County & $7,817,171$ & 0 & 4.5 & & & & $7,817,171$ & 0 & 4.5 \\
\hline Otago & $3,014,436$ & 2 & 10 & & & & $3,014,436$ & 2 & 10 \\
\hline Southland District & $12,317,847$ & 2 & 31 & & & $12,317,847$ & 2 & 31 \\
\hline Total & $2,222,133$ & 0 & 11 & & & & $2,222,133$ & 0 & 11 \\
\hline
\end{tabular}

following military service and becoming part of the new class of gentry or at the very least, provide an ability to develop a sound future for themselves through farming. ${ }^{273}$

Settlement also provided the ability to outnumber the existing indigenous population and in doing so, by armed fashion, maintain peace and stability in the new colony.

${ }^{273}$ Pearson, Dream Deffered, p.46. 
Another aspect of confiscation was economic expansion. Connected with the possession of land, economic expansion was gained through active farming and creating a primary industry that fed local, national and international markets and consequently provided a taxation system that allowed much needed revenue for local and central government. The notion of economic expansion was considered by the colonial and future governments as being in the public or national interest and so all available land, including waste land, was to be utilised for that task.

These aspects enabled confiscation to be effected in the Waikato and were the underlying drivers for the colonial government's ability to acquire Māori land there. In essence the acquisition of land by colonisation and confiscation, sought to develop a firm foundation for colonial and settler development premised on developing their shared goals and values while intentionally or otherwise, setting Māori interests apart. William Martin sums up the position Waikato Māori faced after the invasion of Waikato by arguing that

If those men, after giving the best proof of their intention not to "levy war" against the Queen, yet seeing their territory entered by an armed force, and property destroyed by that force, stood up to resist, ought we not in fairness to conclude that they resisted, not because they were traitors, but rather because they were New Zealanders, or because they were men. ${ }^{274}$

Although Waikato enjoyed the fruits of their own economic expansion from the $1820 \mathrm{~s}$ to $1850 \mathrm{~s}$, that was short lived as colonisation, invasion and confiscation swept through the region in the $1860 \mathrm{~s}$. Confiscation was a vital component of the colonisation project in New Zealand as it provided the basis upon which the Crown and the colony was able to acquire 1.2 million acres in Waikato alone.

The following chapter will examine the key government agencies that were involved in progressing the legislative confiscation that encompassed tenurial revolution and show further how Māori interests, particularly in the Waikato, were either marginalised or ignored while settler interests continued to thrive.

${ }^{274}$ Martin, 'Proposal to take Native lands', p.14. 


\section{CHAPTER FOUR: NGĀ TARI RAUPATU - AGENTS OF ALIENATION}

Kaua te tau e pokea, kaua te tau e rewenatia.

Ko ia hoki te tuturutanga i heke iho nei i ō tātou tūpuna, i a ia i pine nei i nga ra o ō tātou Matua.

Ko ia te tapu i ngohe ai nga mea nanakia, 1 rarata a inga mea matakana. ${ }^{275}$

Neither betray wisdom nor tarnish its intent, wisdom, the blueprint bequeathed to us by our ancestors, providing security through the traumatic days of our elders.

The unseen spirit that restrains the desperate, as it befriends the friendless.

After the creation of the Native Land Court in 1865, the activities of the Compensation Court during the 1860s and 1870s, and the public works activities that pushed through the Waikato, Tāwhiao became frustrated that government officials were not seeking his permission to enter into his rohe, build roads and other works, or hold Land Court meetings. ${ }^{276}$ Despite the invasion of the Waikato, Tāwhiao still believed that he held authority, particularly in Maniapoto (King Country) and by 1881, Tāwhiao instructed all "Pakehafied Māori" to leave the Maniapoto, considering them agents of the government. ${ }^{277}$

Tāwhiao's greatest concern was the Native Land Court and those Māori land owners that appeared willing to sell. The Court was instrumental in creating rifts amongst the hapū of Waikato, leading Tāwhiao to expound the tongikura above. ${ }^{278}$ Tāwhiao likened these rifts amongst his people with the granting of newly individualised title to Māori whereby the arbitrary nature of the Native Land Court often caused whānau to argue amongst themselves so as to secure the few remaining land blocks they had occupied and cultivated for generations. Turongo House argues that:

\footnotetext{
275 Turongo House, Tāwhiao, p.132.

${ }^{276}$ Ibid.

${ }^{277}$ Ibid, p. 131.

${ }^{278}$ Ibid, p. 132.
} 
The King found that after the war the times were as distressing as during the conflict. $^{279}$

Tāwhiao's tongi directs his people to hold on to the teachings of his elders so that the land will nourish, protect and provide security during the hardships Waikato were going through. However, in the midst of his exhortation to his people, the Colonial government had already set in place the agencies that would facilitate the further alienation of Māori land and the policies aligned to Locke's notions of productivity. For Ngāti Hine, the period following the war had a significant impact. Their economic expanse, as mentioned in Chapter Two, provided for their own livelihoods and a healthy trade in Auckland. However, their trade to Auckland and Onehunga had ceased following the war and their freedom to move through the Ngāti Hine boundaries was limited by a settler community that was fully armed and unafraid to protect themselves from 'rebel Māori'. At this time, Māori were forbidden to carry arms to protect either themselves or their land, unlike settlers who were encouraged to establish gun clubs with the purpose of suppressing any further rebellion. ${ }^{280}$

As whānau retreated to Pōkaewhenua or Takapūruharuha after the invasion, Native Assessors began to determine what lands were to be set aside for rebels. A Proclamation on 23 October 1879, created reserves within the confiscated areas for rebel Māori. Section 4 of the Confiscated Lands Act 1867 allowed the government to

Grant such portion or portions thereof as he shall think fit to such person or persons of the Native race as shall be proved to his satisfaction to have been rebellion and have subsequently submitted to the Queen's authority or by warrant under his hand to set apart out of the lands so reserved... as he shall think fit for the benefit of any such person or persons. ${ }^{281}$

Ninety-one hapū and iwi were listed as being in rebellion including Ngāti Hine, with 16 blocks in the Parish of Whangamarino set aside for their use. ${ }^{282}$ Although Te Ao

\footnotetext{
279 Ibid.

${ }^{280}$ C. Sherson, Kahikatea, Cabbage Trees and Koromiko, Waiuku, W.J Deed Printing Ltd, 1981, pp1617.

${ }^{281}$ Confiscated Lands Act 1867.

${ }^{282}$ Hercules Robinson, 'A Proclamation: Reserves made under Section 4, "Confiscated Lands Act, 1867", New Zealand Gazette, 23 October 1879, pp. 1480-1481. Those land blocks were Lots 473, 471, $299,302,171,174,10,332,317,314,309,316,300,370$ and 325 with a total of 2,251 acres and 4 roods.
} 
Mārama and her whānau were included as members of Ngāti Hine, the land blocks that were set aside did not include Pōkaewhenua where her whānau was living. In 1884, following an investigation by the Native Assessor, George Wilkinson, Ngāti Hine was confimed as having continued occupation at Pōkaewhenua based on take noho and take tūpuna. Pōkaewhenua was set aside as a native reserve and in that same year, Ngāti Hine was confirmed through correspondence as grantees. ${ }^{283}$ In the meantime, providing land to meet settler demand continued to be the platform for government policy and practice.

Demands for Māori land were evident in the 1850s when the Crown failed, in the opinion of settlers, to acquire enough land for the progression of settlement. Settlers in the province of Auckland wrote to the Crown in 1859 expounding the "evil effects" of the slowing down of sales by Māori, arguing that it was a "serious impediment to the progressive settlement of the country". 284

Chapter Three explained how, as part of an aggressive colonial project, the confiscation of over 1.2 million acres in Waikato required a bureaucracy with the means to administer, distribute and facilitate further land acquisition. The passing of legislation and the creation of agencies to facilitate Māori land alienation became prevalent in the 1870 s and 1900s.

This chapter examines key government agencies by looking at their policies and their intersection with the Native Land Court and the Māori Land Court. The Native Land Court of the 1860s and the Māori Land Court of the 1960s will, in this Chapter, be the binary pivots for the associated agents to ascertain how these agents influenced or affected the alienation of Māori land. By comparing these two Courts, it is my assertion that little has in fact changed. A policy of confiscation for settlement has effectively remained through the facilitated sale or alienation of Māori land which was encouraged and retained through to the 1960 s.

\footnotetext{
${ }^{283}$ George Wilkinson to Assistant Surveyor, 20 October 1884, Lands and Survey Office (BAAZ), series 1108 57b/2005, Archives New Zealand, Auckland.

${ }^{284}$ Hugh Kawharu, 'Foreward' in David Williams, Te Kooti Tango Whenua: The Native Land Court 1864-1909, Wellington, Huia Publishers, 1999, p.129.
} 
The Native Land Court of the 1860s and the Māori Land Court of the 1960s bore little difference in its practice of alienation. Both Courts progressed the same purpose, undertook similar processes and effected the transfer of Māori land out of Māori ownership in the national interest. The rules guiding the Native and Māori Land Court also remained the same and the supporting agencies were fundamentally the same. Other agencies played a role and although the Native Land Court was the predominant instrument of alienation in the $1860 \mathrm{~s}$, there were a number of associated, aligned and influencing agencies that also played a direct part.

\section{Agencies}

Agencies such as the Compensation Court, Public Trustee, Native and Māori Trustee, Department of Lands and Survey, Valuation Department, Executive Council, Governor General and his office, Department of Agriculture, and the Departments of Native and Māori Affairs, all played a role in alienating Māori land.

The overarching or umbrella agency that directed and guided the Native Land Court and Native Trustee was the Native Affairs Department, which was similarly the case in the 1950s and 1960s with the Department of Māori Affairs. In the 1840s and 1850s however, the administrative body overseeing Māori land was the Governor and his Executive Council made up of the Colonial Secretary, Colonial Treasurer and the Attorney General. $^{285}$ The overall responsibility was held however, by the Governor who sought to maintain control over Native Affairs and Native land issues until it was passed over to parliamentary oversight in 1856 under the Native Reserves Act.

\section{Governor administration of native land}

After the signing of the Treaty of Waitangi in 1840 the Crown had a guaranteed right of pre-emption in Māori land sales. As mentioned in Chapter Three, the practice of preemption meant that immediately following the signing of the Treaty of Waitangi, Māori were only able to dispose of their land to the Crown. Throughout the 1840 s the demand for land grew and by 1844, Governor Fitzroy had implemented a system of pre-emption waivers allowing Māori to alienate land directly to settlers but with some measure of

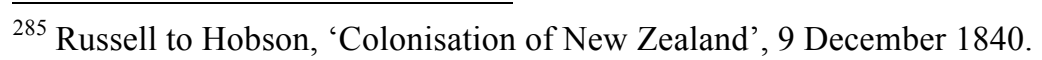


oversight by the Crown. ${ }^{286}$ On Governor Grey’s arrival in 1846, Fitzroy’s pre-emption waiver was reversed and the Native Land Purchase Ordinance was drafted but failed to be implemented. The Ordinance sought to have settlers lease or obtain licenses from the Crown, but not to directly purchase or occupy Māori land without first being confirmed by the Governor. Infractions on the part of Māori and settlers saw the scheme fall into disuse. ${ }^{287}$

In 1856, the new Governor, Gore Browne established a Board of Native Affairs to consider issues surrounding Māori land, such as a more reliable land purchasing scheme, the type of titles for transferred Māori land and the appointment of Māori resident magistrates. ${ }^{288}$ The Board brought back mostly unusable recommendations other than to encourage Gore Browne to create a Native Secretary which was implemented and then joined with the Chief Commissioner for Land Purchases, effectively consolidating the two offices. ${ }^{289}$

The consolidation of these offices had the impact of subsuming Native Affairs and Native interests under the auspices of purchasing land for settlement. In Fenton's report concerning Native Affairs in the Waikato region, Fenton (who held both positions of Native Secretary and Chief Commissioner for Land Purchases) argued that the strong desire by Māori to retain land and his role to assuage settler demand, by acquiring Māori land "has much to do with pertinacity in agitation". ${ }^{290}$ Fenton argued that

we encouraged or caused this feeling by the consolidation of the Land [Purchase Department] with the Native Department. I always looked upon this consolidation as imprudent... The suppression of the Native Secretary's

\footnotetext{
${ }^{286}$ Robert Hayes, 'A Study of the origins of the crown's policy on Imposing restrictions on land alienation and its administration', Research report commissioned by the Crown Law Office, 2000, p.13. ${ }^{287}$ Ibid, pp14-16, see also Donald Loveridge, 'The Origins of the Native Lands Acts and Native Land Court in New Zealand', Evidence of Donald Loveridge concerning the origins of the Native Land Acts and Native Land Court in New Zealand, WAI No 686 and WAI 100 \& Ors, Wellington, Crown Law Office, 2000, p.54.

${ }^{288}$ T.W Bates, 'The Administration of Sir Thomas Gore Brown, Governor of New Zealand 1855-1861', Masters Thesis, Victoria University College, 1947, pp.71-72 and Hayes, 'Crown's policy', p.16. ${ }^{289}$ Ibid, p. 75 .

${ }^{290}$ Francis Fenton, 'Journal of F.D Fenton, Resident Magistrate of Waikato, Commencing July 12, 1857: Enclosure in No. 3', Further Papers relative to Native Affairs', AJHR, Session I, E-01c, 5 October 1857, p.21.
} 
Department commenced when...the office became thoroughly subordinate and the acquisition of land was the only object really attended to. ${ }^{291}$

Attempts to resolve Māori land issues continued with the passing of the Native Territorial Rights Act of 1858, and the Native Council Act of 1860, the former of which was disallowed by the Imperial Government and the later having been interrupted by the Taranaki war. ${ }^{292}$

Gore Browne was replaced by Governor Grey in 1861, who also tried to have legislation implemented to resolve land issues namely with the Native District Regulations Act of 1858. With the continued demand by settlers to acquire land, the formation of the Kingitanga and the government's desire to go to war, the Native District Regulations Act was overtaken by the Native Land Act 1862 (and 1865), the New Zealand Settlements Act, 1863, the Suppression of Rebellion Act, 1863 and the New Zealand Loans Act 1863 which culminated in the funding of the invasion of Waikato, the confiscation of Waikato land and the transfer of confiscated land into Crown title.

\section{Native Land Court}

The Native Lands Act of 1865 was the bedrock of the Native Land Court, despite being amended in 1866, 1867, 1868, 1869, 1870 and repealed in 1873. The Native Land Court sat under the Native Department, which was directly governed by the Executive. The key purpose of the Native Lands Act, 1865 (and therefore the Native Land Court) is set out in its preamble. The Act was to

amend and consolidate the Laws relating to Lands in the Colony in which the Māori Proprietary Customs still exist, and to provide for the ascertainment of the Titles to such Lands, and for regulating the Descent thereof, and for other purposes. ${ }^{293}$

In order to carry out these duties, the Act also created the Native Land Court, which set aside the pre-emption of the Crown and allowed direct selling of Māori land to settlers.

\footnotetext{
291 Ibid.

${ }^{292}$ Hayes, 'Crown's policy', pp. 21 and 25.

${ }^{293}$ Preamble to the Native Lands Act 1865.
} 
Where the Native Territorial Rights Bill had failed, the government hoped that individualising Māori interests in customary land would allow quicker access to Māori land. Little was achieved with this Act, probably due to the invasion of Waikato, so Legislators drafted a new Act in 1865 that sought the same ends, and means, by creating the Native Land Court.

The extinguishment of native title and the deriving of Crown grants was central to the Crown's idea of tenurial revolution for the purpose of pre-emptive purchase by the Crown and on-sale for settler development. A Native Land Court Judge of the time argued that the Land Court Judges considered that

[i]t would be highly prejudicial to allow the tribal tenure to grow up and effect land that has once been clothed with a lawful title, recognised and understood by the ordinary laws of the Colony...it will be the duty of the Court in administering this Act to cause as rapid an introduction amongst the Maoris [sic], not only of English tenures but of English rules of descent as can be secured without violently shocking Maori prejudices. ${ }^{294}$

The awarding of individual interests removed customary notions of communal ownership by whānau and hapū, which in a Lockean mode of thinking was a burden to productivity. The idea that a collective group of people could utilise land profitably was neither imagined nor considered valid by Colonists, or Locke for that matter, despite Ngâti Hine and Waikato utilising land in that manner in the 1820 s to the 1850 s to feed Auckland.

As mentioned in Chapter Three, Fox argued that individualistic farming endeavours were considered both preferable and more successful. ${ }^{295}$ This bias negated historic examples in the Waikato that proved otherwise. The reality then is that individualistic farming was preferred given the theory behind it aligned with European world views of productivity.

\footnotetext{
${ }^{294}$ Mr Rogan, 'Native Secretary's Office', New Zealand Gazette, 17 April 1867, p.189.

${ }^{295}$ Fox to Waiapu, 'Papers relative to Native Affairs', p.78.
} 
Another consistent theme of the Native and Māori Land Court was the argument that unoccupied or seemingly unproductive Māori land was waste land. The key focus of the Courts' activities was a continuous theme from the 1860s-1880s and again in the 1950s-1960s that unproductive land was seen as wasteful and the individualising of Māori land allowed land to be sold to those better able to utilise it for the economic security of the colony. ${ }^{296}$

\section{Waste Lands}

For the settler government, the policy during the 1850s was that "any Māori land not directly used for cultivation was classified as 'waste land' belonging to the Crown and stripped of native title". ${ }^{297}$ This idea of waste lands as covered in Chapter Three, takes as its premise, John Lockes notion of land utilisation whereby land left idle should revert to the common pool for redistribution. ${ }^{298}$ This can be seen in the 1846 Royal Instructions to Governor Hobson that denied "Māori customary rights to land beyond habitations and cultivations" ${ }^{299}$, labelling all supposed unutilised land as waste land. The Royal Instructions state that

the right of such aboriginal inhabitants to such lands has been acknowledged and ascertained, or that the claimants or their progenitors, or those from whom they derived title, have actually had the occupation of the lands so claimed, and have been accustomed to use and enjoy the same, either as places of abode, or for tillage, or for the growth of crops, or for the depasturing of cattle, or otherwise' for the convenience and sustentation of life, by means of labour expended thereupon. ${ }^{300}$

Access to waste land became an important issue for settlers and the colony and in 1854 the Waste Lands Act was passed in the first session of the General Assembly. Although restricted to Crown lands, Superintendents and Provincial Councils were able to advise the Governor to

\footnotetext{
${ }^{296}$ See Chapter 3 and McGillivary, Return of the Crown Lands', 17 August 1871.

${ }^{297}$ F Hackshaw in Nan Seuffert, 'Colonising Concepts of the Good Citizen, Law's Deceptions, and the Treaty of Waitangi', Law Text Culture, 4, 2, 1998, p.80.

${ }^{298}$ Locke, Second Treatise, Sections 44-45.

${ }^{299}$ New Zealand Law Commission, 'Māori Customs and Values in New Zealand', Study Paper No. 9 , Wellington, 2001, p.24.

${ }^{300}$ British Parliament, 'The Queen's Instructions under the Royal Sign Manual and Signet, accompanying the New Zealand Charter', London Gazette, Issue 20687, 29 December 1846, p.6010.
} 
issue regulations for the sale, letting, disposal and occupation of Crown waste land in their respective provinces. ${ }^{301}$

With the wholesale confiscation of land in the 1860s and the suspension of the Crown's pre-emption from 1862 to 1892 , much of the Crown's waste land was acquired through purchase and confiscation, which was then transferred to the settlers. Table 1 in Chapter Three gave an example of waste land purchased in the Auckland Province which was almost commensurate with land confiscated under the New Zealand Settlments Act. From 1856-1876, this amounted to ten million acres. ${ }^{302}$

However, according to Sir William Martin, while giving his opinion on Native Tenure in 1860 , there were in the opinion of Māori, no waste lands amongst them. ${ }^{303}$ Sir William Martin, the First Chief Justice in New Zealand, in submitting his opinions to McLean (Commissioner for the Purchase of Native Lands) argued that "there is not an acre of land available for the purposes of colonization but has an owner amongst the Natives according to their own customs". ${ }^{304}$ By Martin's account, Māori utilised every acre under their authority either by habitation, cultivation, extensive hunting grounds, fishing grounds or for the use of obtaining resources, such as totara trees for canoes. ${ }^{305}$

In the 1840 s to $1860 \mathrm{~s}$, waste land had been acquired for between 1 penny to $£ 1$, confiscation and also by Māori selling their land following title investigation. The land now available to the Government was vast in terms of their acquisitions in the Waikato, Taranaki, Bay of Plenty and elsewhere. With these lands now in Crown ownership there appeared little need to distinguish previously owned Māori land as waste land. Despite this however, the emergence of the Native Land Court allowed title investigations to determine ownership and occupation of land by Māori so that those lands that were considered unoccupied and unutilised were also available for settlement.

\footnotetext{
${ }^{301}$ R.J. MacLachlan, 'Land Administration in New Zealand: An Evolutionary account of the influence of land policy on New Zealand's social, economic and physical development', Wellington, Government Printer, 1968, p.6.

${ }^{302}$ Ibid, p.7.

${ }^{303}$ William Martin, 'Appendix A: Native Tenure: Extracts from Opinions of Various Authorities', $A J H R$, Session I, E-01, 1861, p.4.

${ }^{304}$ Ibid.

305 Ibid.
} 
Within the Waikato, the Native Land Court played a different role than elsewhere in the country. As a court of title investigation, Māori were granted land based on take whenua by customary occupation, cultivation, acquisition or ancestry. In the Waikato, the confiscation of Māori land by-passed the need to investigate customary ownership. Crown grants were provided to Māori that could prove that they were either loyal to the Crown or had acquiesenced and sworn allegiance to the Queen as returned rebels. Customary title in Waikato, was immediately replaced by Crown titles following confiscation and those Māori who were granted land after 1863, did so via the Compensation Court in the first instance and then the Native Land Court through confirmation of title.

\section{The Compensation Court}

The Compensation Court was established under Section 8 of the New Zealand Settlements Act 1863 for the purpose of determining claims for compensation by those Māori who could prove they were loyal to the Government but who had lands confiscated under the proclamations issued by the Crown and advertised in the Gazette. Initially, compensation awards were made in cash but by 1867 , awards were also made in land for rebels where investigations were successfully pursued through the Court. ${ }^{306}$

The Compensation Court was presided over by Chief Judge Fenton and sitting Judges, Rogan and Munro, all three of whom were also Native Land Court Judges. Māori applied to the Compensation Court for lands confiscated which was investigated to determine whether they had been loyal and then also whether they had held continuous customary occupation on the land they were claiming. ${ }^{307}$

However, it was not until the New Zealand Settlements and Amendment and Continuance Act of 1865 that loyal Māori were able to get compensation in land. ${ }^{308}$ In the two years since the original Act, loyal Māori were compensated in money only. The Amendment and Continuance Act states that

\footnotetext{
${ }^{306}$ Ann Parsonson, 'Tainui Claims to Onewhero and Maramarua Forests: Historical Overview', Scoping Report commissioned by the Tainui Māori Trust Baord in association with the Crown Forest Rental Trust, 1995, p.201.

307 Ibid.

${ }^{308}$ Ibid, p. 198.
} 
In any case of claim for compensation the Colonial Secretary on behalf of the Crown and the claimant may agree that land shall be given either wholly or in part by way of compensation for such claim in lieu of money and land may be so granted accordingly out of any land within the same Province subject to the provisions of the said Act. ${ }^{309}$

The inclusion of "rebel" natives in compensation hearings and awards was delayed until the Confiscated Lands Act 1867. Although the New Zealand Settlement Act and the Suppression of Rebellion Act had referred to Māori being in rebellion, the class of 'rebel' is more apparent in 1867, through the creation of reservations for 'rebel Natives'. ${ }^{310}$ Rebel grantees were accorded the rights to occupy and utilise the land, but did not have the right like other Māori to own or alienate to third parties should they wish to do so. ${ }^{311}$

The inclusion of "rebels" in the 1867 legislation was also the first mention of this class of people in New Zealand legislation. To become eligible for land grants, Māori were required under Section 4 of the Act to submit to the authority of the Queen by signing a declaration admitting to being a rebel. The clause states specifically:

\section{Power to make reserves for surrendered rebels}

4. It shall be lawful for the Governor...to reserve out lands...to such persons or persons of the Native race as shall be proved to his satisfaction to have been in rebellion and have subsequently submitted to the Queen's authority. $^{312}$

There is confusion however on how loyalist and rebels were identified. Some self identified and were supported by others that were similarly placed, while others could be denied by key leaders on either side. There were however whānau members who fought on both sides during the invasion and those who did clearly identify themselves

\footnotetext{
${ }^{309}$ Section 9, New Zealand Settlements Amendment and Continuance Act 1865.

${ }^{310}$ See Wilkinson correspondence re Pōkaewhenua classification as a 'Reservation for Rebel Natives', 20 October, 1884, Lands and Survey Office (BAAZ), series 1108 57b/2005, Archives New Zealand, Auckland.

${ }^{311}$ Heather Bauchop, 'The Aftermath of Confiscation - Crown Allocation of Land to Iwi: Taranaki 186580: A Case Study in confusion', Report for WAI \#143, I18, June 1993, pp.22-3.

${ }^{312}$ Confiscated Lands Act 1867.
} 
as "rebels". Rebels were then required to sign a Declaration admitting to their guilt and the wrong doing of their tribe before they were able to complete an application to the Compensation Court to claim undisposed lands previously occupied by them. The application stated the following:

He kupu whaakaatu tenei naku kia koe mo toku piihi whenua i roto i nga rohe o te whenau kua tangohia e te Kawana mo te hara o nga iwi o Waikato. E hiahia ana hoki ahau kia whakawakia e te Kooti Whakarite toku tikanga ki taua pihi. He oti ano. Na to hoa. Ko te ingoa o taua whenua ko...I te takiwa ki... Ko nga rohe i timata ki... ${ }^{313}$

Translated as: This is my application to you for my piece of land in the districts that were taken by the Governor for the sins of the peoples of Waikato. I want to be judged by the deciding Court my rights to that piece therefore. From your friend. The name of that land is... In the district of... The boundaries start at...

Rebel Māori did not participate fully in the Compensation Court process until 1879 when a list was produced and those hapū and individuals were proclaimed as Rebels in the New Zealand Gazette. As mentioned previously, 91 hapū and iwi were listed as being in rebellion, with 348 blocks throughout Waikato made available for its rebel members. $^{314}$ Within those hapū and iwi, 1,209 individuals were named (including in some cases the number of children that were with them), as well as 11 whānau with unspecified numbers. ${ }^{315}$ Sixteen of the land blocks listed fell within the Parish of Whangamarino and eight rebels identified as Ngāti Hine. ${ }^{316}$ A number of other hapū were also included that were either placed within the Parish or were likely to have married into Ngāti Hine. The other hapū that features predominantly is Ngāti Naho who is closely associated with Ngāti Hine.

\footnotetext{
${ }^{313}$ Raupatu Document Bank, 'Index of Native Land Compensation Awards', Vol 104, 1867, p.40121.

${ }^{314}$ Robinson, 'Reserves made under Section 4', pp.1481-1482.

${ }^{315}$ Hercules Robinson, 'Warrant setting apart Land for Rebel Natives under "Confiscated Lands Act, 1867", New Zealand Gazette, 23 October 1879, pp.1483-1491(Please note that Robinson has 2 Warrants listing Rebels and their land grants. The first starts on page 1482-1491 and the second starts on page 1491-1498.

${ }^{316}$ Ibid, pp. 1483-1498.
} 
The area allocated in the Gazette proclamations totalled 37,042 acres ${ }^{317}$ and was situated mainly in the Whangapē, Pirongia, Waahi, Waipa and Tauwhare areas. On average, the land grants in those areas were approximately 45 acres per person, with the smallest grant at 1 acre and the largest single grant of 500 acres. The land grants were variable and none of those blocks listed included Pōkaewhenua, Takapūruharuha, or Te Ao Mārama's whānau. Although set aside as native reservations for Ngati Hine, both Pōkaewhenua and Takapūruharuha were under a separate investigation to determine grantees through the local Native Assessor.

The administration of the Compensation Court was set out in an Order of Council that provided broad guidelines for its operation. In practice however, the rules appeared to be haphazard and followed a Judge's preference or prejudice. There was a lack of consistency, particularly given there were few rules put in place to guide judges and although judgements were apparently based on the merits of the case, the lack of rules provided an inconsistent practice and often cases in the Waikato were settled out of court. $^{318}$

There were however two instances where rules were consistently applied in the Compensation Court and later the Native Land Court: the 1840 rule and the removal of distinguishing between loyal and rebel Māori.

The 1840 rule applied by Judge Fenton was created to ensure a fixed date from which claims and investigations could be undertaken. Fenton required a fixed date to determine occupation so as not to be confused by recent (1840-1870) settlement of land through war, other disturbances or migration. ${ }^{319}$ Fenton settled on 1840 as he argued that

all persons who are proved to have been the actual owners or possessors of land at that time must be regarded as the owners or possessors of those lands now, except in cases where changes of ownership or possession have

\footnotetext{
${ }^{317}$ Parsonson, 'Tainui Claims', p.201.

${ }^{318}$ See Raupatu Document Bank, Vol 104, p.40098 which specifically refers to "Hauraki claimants to land in Waikato - arranged out of Court by Mr MacKay (Pukorokoro, Maramarua, Whangamarino)". ${ }^{319}$ Francis Fenton, 'Papers Relating to the Sitting of Compensation Court at New Plymouth', Further Papers Relative to Native Affairs, AJHR, Session I, A-13, 12 July 1866, p.4.
} 
subsequently taken place with the consent, expresses or tacit, of the Government, or without its actual interference to prevent these changes. ${ }^{320}$

Fenton saw 1840 as a natural point given the British Government was considered to have been established, presumably by the signing of the Treaty of Waitangi. Fenton was reticent to adjudicate over land claims by those Māori who had been dispossessed prior to 1840 by other hapū or iwi due to inter-tribal war or by force. Fenton argued that

We do not think that it can be reasonably maintained that the British Government came to this Colony to improve Māori titles or to reinstate persons in possessions from which they had been expelled before 1840, or which they had voluntarily abandoned previous to that time. ${ }^{321}$

A component of this rule also required that the lands claimed were in actual occupation or cultivated which did not necessarily include seasonal mahinga kai areas. As a result of this stationary use of land, the 1840 rule encouraged adversarial Court exchanges between Māori seeking to claim sparse areas of available land. Customary use was minimised despite its ongoing practice in Pōkaewhenua where Ngāti Hine utilised resources at Takapūruharuha (Waikare), Kaiaua, Rangiriri and Matahuru while maintaining a papakāinga at Okarea. ${ }^{322}$ Through the Compensation Court process however, Te Ao Mārama's whānau were limited to either Pōkaewhenua or Takapūruharuha.

To the benefit of Māori however, the second rule introduced by the Compensation Court was the eventual equality of loyal and rebel Māori. With little ability to determine who was either loyal or rebel, a number of claims in the Compensation Court were settled out of court or rebels were included where confusion made it impossible to tell the difference. $^{323}$

\footnotetext{
${ }^{320}$ Ibid.

${ }^{321}$ Fenton, 'Compensation Court at New Plymouth', p.4.

${ }^{322}$ Ngawini Puru, Interview, 4 October 2011, Auckland.

${ }^{323}$ Fenton, 'Compensation Court at New Plymouth', p.4.
} 
Within the context of its inquiry, the Compensation Court focused on whether Māori could prove they had been loyal to the Crown during the War, before they were eligible to reclaim lands taken from them. So although some assurances were given to those Māori who had fought with the Crown, those assurances were lost amongst the confusion of confiscation and the "greater confusion that was the Compensation Court". 324

The subjectivity of guilt or innocence was left for the sitting Judge or the Native Assessor assisting in the proceedings as to who should be awarded land grants. As was the case in many areas, some families were split by war and could be adversely or positively affected depending on the Judges' discretion on the day. One of the main Native Assessors of the Compensation Court, Native Land Court and Major in the Crown's army, Wīremu Te Wheoro, declared the entire Ngāti Pou hapū as rebels. ${ }^{325}$ Although loyal Māori were able to receive either money or land in compensation as a result of the New Zealand Settlements Amendment and Continuance Act 1865, as mentioned above, land was only made available to rebel Māori from $1867^{326}$ but not enacted till after 1879 .

The confusion generated by the Compensation Court provides little evidence of considered and systematic decision making. It is unclear if Māori received any benefit from the process and although some 1,209 Waikato members received land grants in 1879, the remaining chapter will show how this was whittled down not long after title was granted or the granting of titles not actually confirmed in the Court (Chapter Five will show how Pōkaewhenua was granted in 1883 but not confirmed in the Court until 1927).

Māori who received cash payments in lieu of land, or both, were provided minimal payment in comparison to the land holdings they held previously and in some cases, grantees were given lands that belonged to other whānau and hapū.

\footnotetext{
${ }^{324}$ Vincent O’Malley, 'An Entangled Web: Te Aitanga a Mahaki Land and Politics, 1840-1873, and their Aftermath', Wellington, Te Aitanga a Mahaki Claims Committee, 2000, p.221.

${ }^{325}$ Parsonson, 'Tainui Claims', p. 196.

${ }^{326}$ New Zealand Settlements Amendment and Continuance Act, 1865.
} 
The Compensation Court failed to provide adequate land to rebel or loyal Māori and by 1880, as Waikato Māori who had resided in Maniapoto or other parts immediately after the invasion of Waikato returned to the Waikato, further land or reservations were required to settle the newly returned rebels. ${ }^{327}$ To that end, the Government passed the Waikato Confiscated Lands Act 1880 with the express purpose of settling Waikato Māori back on lands that had not yet been sold or disposed of. ${ }^{328}$ The area defined in the Act was those lands confiscated in the Waikato and unlike the 1867 Act, the Waikato Confiscated Lands Act also required that Māori be in continuous occupation of the block. Should Māori move away from the block and not return for two years, the Crown was within its rights to revoke the grant. ${ }^{329}$

Despite this measure, a number of Waikato Māori were still landless, including those that had been listed as grantees for land in 1879 and Māori that had been promised land by Native Assessors following the 1880 legislation. In 1900, a list was published in the Appendix to the Journal of the House of Representatives naming all those Māori in the Waikato, Hauraki and Tauranga area who had lost their land by confiscation and were still considered landless. ${ }^{330}$ Of the 3,549 listed, the great majority were Waikato including those of Ngāti Hine and Ngāti Marae descent, numbering 105 hapū members. $^{331}$

At the conclusion of the compensation hearing (if one was held), land that was set aside for the claimants was then passed back to the Native Land Court to confirm their land title as a grant from the Crown.

By virtue of its personnel and objective (to transfer Māori customary land to English tenure), the Compensation Court was practically the same creature as the Native Land Court. Once title was granted to Māori, the ability of Māori to alienate their land was instantaneous. As pointed out by Boast, both Courts were presided over by the same

\footnotetext{
${ }^{327}$ Parsonson, 'Tainui Claims', p.202.

${ }^{328}$ Preamble to the Waikato Confiscated Lands Act 1880.

${ }^{329}$ Ibid, Section 7.

${ }^{330}$ John MacKay, 'Landless Māoris in the Waikato, Thames Valley, and Tauranga Districts: Who lost their land by Confiscation', AJHR, Session I, G-01, 22 May 1900.

${ }^{331}$ Ibid.
} 
Chief Judge, Fenton, and had the same sitting Judges in Judge Rogan and Judge Munro. $^{332}$

\section{Native Land Court}

The Native Lands Act of 1865 provided the means for the establishment of the Native Land Court the purpose of which was to ascertain the ownership of Māori customary title and "then confirm their rights to sell their land". 333 Former Māori Land Court Chief Judge, Joe Williams ${ }^{334}$ argues that the Native Land Act of 1865 had as its express purpose the "facilitat[ion of the] rapid transfer of land out of Māori hands into Crown and settler hands". 335

Its predecessor, the Native Lands Act of 1862 had been developed between the Governor and two of his ministers with various support from other members of the government. Although the Court was to be trialled in certain districts before its full implementation, the Queen's assent did not arrive until May $1863 .{ }^{336}$ By then, the impending invasion of Waikato and the war in Taranaki had overtaken the initiative from being fully implemented.

The 1862 legislation was able to put into effect preparations for the creation of the Native Land Court including the appointment of Francis Fenton as Chief Judge, John Rogan and George Clark Sr. as Judges, eleven Māori assessors, numerous surveyors, additional judges and other office staff. ${ }^{337}$

The Prime Minister, Frederick A. Weld, considered the Native Land Court an "impartial arbiter of justice", but this was difficult to achieve when the

Native Land Court was to be the principle vehicle by which Māori customary land was made available for colonization, through its conversion to freehold land which could be purchased or leased by European settlers. ${ }^{338}$

\footnotetext{
${ }^{332}$ Richard Boast, 'Māori and the Law, 1840-2000', Peter Spiller, J Finn, R Boast, eds., A New Zealand Legal History, Wellington, Brooker's, 2001, pp.148-9.

${ }^{333}$ David Williams, Te Kooti Tango Whenua: The Native Land Court 1864-1909, Wellington, Huia Publishers, p.157.

${ }^{334}$ Joe Williams, 'The Māori Land Court: A Separate Legal System', New Zealand Centre for Public Law, Wellington, Faculty of Law, 2001.

${ }^{335}$ Ibid, p.2.

${ }^{336}$ Loveridge, 'The Origins of the Native Lands Acts', p.256.

${ }^{337}$ Ibid, pp.278-279.

338 Ibid, p. 279.
} 
The premise upon which the Court was created was not to protect Māori land interests, but to free up waste lands for European settlement. This Court was not impartial particularly when the foundation upon which the Court sat was a European rationale and theory of land use. The intent of the Native Land Court was to privatise Māori land acquisition whereby, following the granting of title to individuals, "the land was freely alienable to anyone". 339

Most Native Land Court judges lacked any legal qualification and profession (other than the Chief Judges) and tended to be retired military officers from the Waikato invasion. The main criteria required of Judges at that time was the ability to be fluent in te reo and have endless patience. ${ }^{340}$ Of the 44 Judges operating in the Native Land Court, only 13 were trained lawyers leaving 31 uneducated in the field. Also, many of the Judges had come from different battlefields around the North Island into a court room to determine whether Māori were granted title. Consider also, that these same judges were now in a position of power over rebel Māori who they had some 12 months earlier tried to kill. It is difficult to believe that the Native Land Court was impartial in the Waikato, as Weld desired.

There was also no separation of powers between the Executive and the Native Land Court and Judges often lacked the ability to act independently of Government policies. ${ }^{341}$ Although the Court was under the auspices of the Native Department, the policy direction and driving goals were dictated by Government agencies and judgements often followed policy lines. Richard Boast and David Williams both argue that there was no separation of powers and that judges lacked any sense of judicial independence. Williams goes on to argue that Judges often collaborated with "government ministers and officials to ensure that the Government...not be embarrassed". 342

There were however favourable accounts of the Native Land Court which are provided by Paul McHugh who argues that Māori were supportive of the Native Land Court and “despite its mainly Pākehā (European) judiciary...the Māori Land Court has been

\footnotetext{
${ }^{339}$ Boast, 'Māori and the Law', p.153.

${ }^{340}$ Ibid, p. 157.

${ }^{341}$ Williams, Te Kooti, p.44.

${ }^{342}$ Ibid and Boast, 'An expensive mistake', p.626.
} 
moulded by the Māori as far as possible towards meeting their needs". 343 There are similar comments in McHugh's 1979 journal article on the alienation of Māori land where he refers to the changed status of Māori land to general land under Part I of the Māori Affairs Amendment Act of 1967, "being of no cultural significance to Māori given land was already being used in a Pākehā way. ${ }^{344}$ Robert Hayes makes a similar argument in his evidence to the Waitangi Tribunal for Wai 686 and Wai 100 by arguing that “many Māori welcomed tenurial revolution". 345

There is little likelihood that iwi who were labelled as rebels and processed through the Compensation Court held favourable ties with the Court. For those who may have benefited from the Native Land Court aside, the process by which claims were heard (as provided in great detail by Bachop ${ }^{346}$ and Parsonson ${ }^{347}$ ) had an adverse economic, social and cultural impact on Māori. In attempts to recover their economic livelihood, Māori did utilise the Native Land Court to secure title to regain what economic opportunities remained following the invasion of Waikato. Ward however argues that it was the Court's intention to facilitate sales so that entrepreneurial Māori could be more like settler farmers by developing individually owned farms for the colony's interest. ${ }^{348}$ To argue that Māori welcomed or influenced the Native Land Court is an exaggeration for Waikato who had no control over or an ability to stop the confiscation of their land.

The Native Land Court of the 1860s and the Māori Land Court of the 1960s bore little difference in their practices of alienating Māori land. The process by which land was alienated in both eras was either through application to the Court by an existing owner or application by a potential lessee or buyer.

\section{The Māori Land Court of the 1960s}

\footnotetext{
${ }^{343}$ Paul McHugh, 'The Alienation of Māori Land under Part XXIII and Section 438 of the Māori Affairs Act 1953', Victoria University of Wellington Law Review, 10, 1979 p.133.

${ }^{344}$ Ibid, p. 154.

${ }^{345}$ Hayes, 'Crown policy', p.3.

${ }^{346}$ Bauchop, 'The Aftermath of Confiscation', 1993.

${ }^{347}$ Parsonson, 'Tainui Claims'.

${ }^{348}$ Alan Ward, An Unsettled History: Treaty Claims in New Zealand Tody, Wellington, Bridget Williams Books, 1999, p.140.
} 
By 1960, very little had changed. The governing legislation for the Māori Land Court and its parent agent, the Department of Māori Affairs, was encapsulated in the Māori Affairs Act of 1953. The governing Board of Māori Affairs had members that included the Secretary of key departments and intersecting policy that influenced the utilisation, productivity and also alienation of Māori land (see Figure 1: Influencing Alienation). ${ }^{349}$

In 1953, the legislation was very clear in stipulating that unoccupied land was to be alienated in the interests of the owners or the public interest. The genesis of this stipulation stretches back to its predecessors in 1907, 1931 and accompanying legislation in 1950 .

The Māori Affairs Act of 1953 made it possible for the Māori Land Court to prescribe exact criteria on how unproductive Māori land be alienated. This Act differed little from the Native Land Settlement Act of 1907 and the Native Land Act of 1931 and even less still from the Māori Purposes Act of 1950. All three Acts implied the same end: that Māori land that was allegedly unproductive, was to be alienated.

The relevant parts of the Acts are summarised as follows:

\section{Native Land Settlement Act 1907}

Preamble

Whereas certain Commissioners were...appointed by the Governor with intent that they should make inquiry as to the areas of Native land which are unoccupied or not profitably occupied, and as to the mode in which such lands can best be utilised and settled in the interests of the Native owners and the public good.

Section 51(1) Any Board may with the consent of the Native Minister dispose of any land vested in it by virtue of this Part of this Act...by way of sale in fee-simple as a site for a dairy factory, cheese-factory, fruitpreserving factory or creamery, or as a site for the erection of any building required for any religious, charitable, educational, or public purpose.

\footnotetext{
${ }^{349}$ The colours outlined in Figure 1 refer to the actions associated with the responsible agency. The brown line going across from the Board of the Maori Affairs refers to the departments' membership on the Board.
} 


\section{Native Land Act 1931}

522(1) For the purpose of the better settlement and more effective utilisation of Native land or land owned or occupied by Natives, and the encouragement of Natives in the promotion of agricultural pursuits and of efforts of industry and self-help, the Native Minister shall have the powers hereby conferred upon him...

3(a) ...the Native Minister may cause to be undertaken and carried out in connection therewith such works as he thinks fit...

3(f)...no owner shall, except with the consent of the Native Minister, be entitled to exercise any rights of ownership in connection with the land affected so as to interfere with or obstruct the carrying out of any works

540. (1) If and whenever the Court is satisfied with respect to Native freehold land or land owned by Natives - (a) That the land is unleased and unoccupied and is not kept properly cleaned of noxious weeds; or

(b) That any beneficial owner cannot be found; or

(c) That any beneficial owner is in a position which renders it necessary or advisable that his land should be dealt with under this section -

and the Court is of opinion that it is in the interest of the owner or in the public interest that the land or any interest therein should be alienated, it may make an order appointing the Native Trustee to execute in his own name as agent for and on behalf of the owner any instrument of alienation...

(2) No owner shall have power to revoke an agency created under this section $^{350}$

\footnotetext{
${ }^{350}$ Native Land Act 1931.
} 
Figure 1: Influencing Alienation - the Agents of Alienation

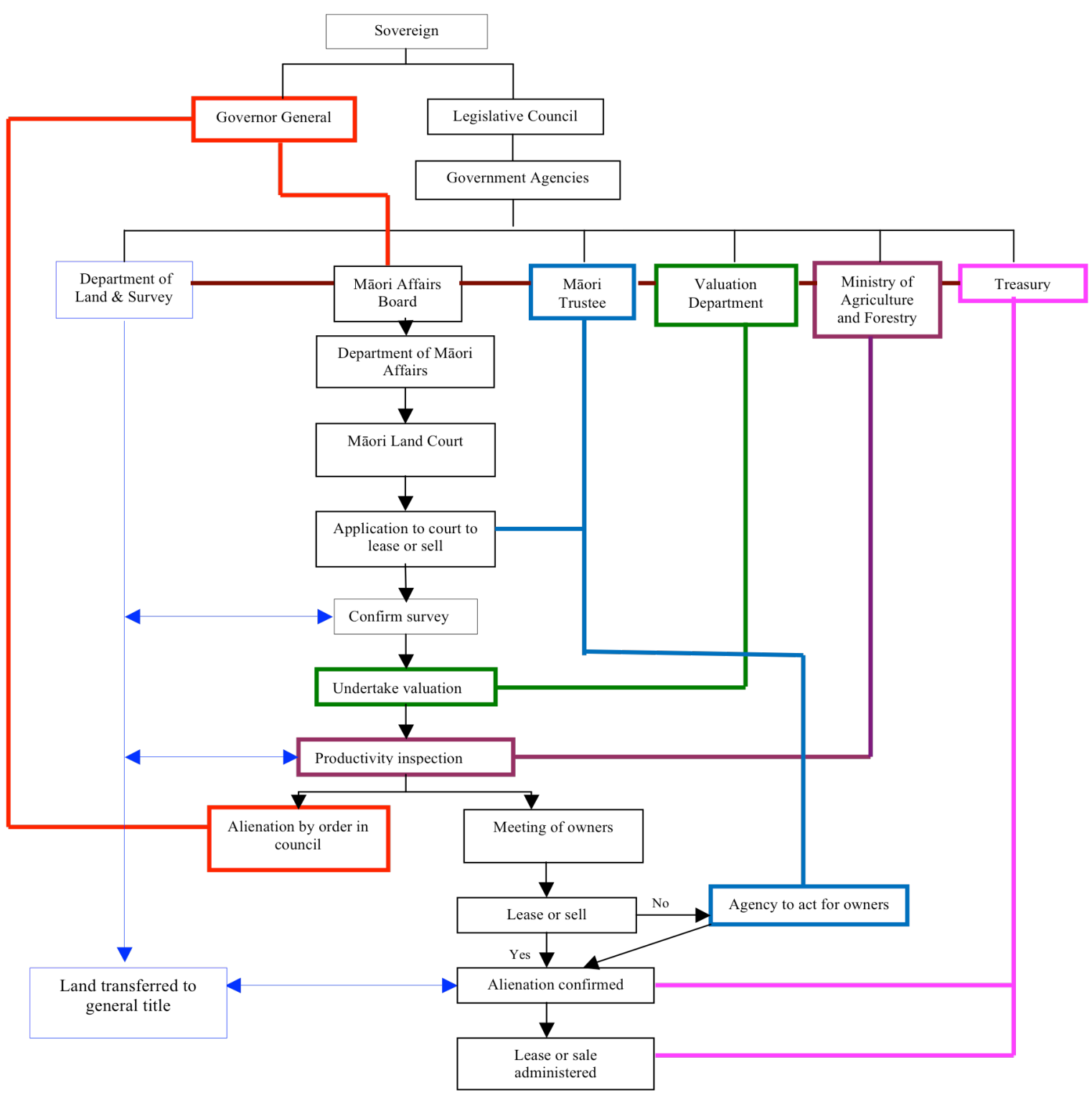




\section{Māori Purposes Act 1950}

34. If and whenever the Court is satisfied

(a) That the land is unoccupied; or

(b) That the land is not kept properly cleared of weeds which are noxious weeds within the meaning of the Noxious Weeds Act, 1950; or

(c) That the owners of the land have neglected to farm or manage the land diligently and that the land is not being used to its best advantage in the interests of the owners and in the public interest; ${ }^{351}$

\section{Māori Affairs Act 1953, Part XXV:}

387. The Court may appoint the Māori Trustee as agent to dispose of unproductive land - (1) Where with respect to any Māori freehold land or European land owned by Maoris [sic], the Court is satisfied -

(a) that the land is unoccupied; or

(b) that the land is not being kept properly cleared of weeds...

(c) that any rates payable in respect of the land...have not been paid and that the amount of the said rates or moneys has been charged upon the land; or

(d) that the owners of the land have neglected to farm or otherwise manage the land with due diligence and that in consequence of their neglect the land is not being used to proper advantage, -

it may on application by the local authority of the district or by any person interested make an order in respect of that land or a defined portion thereof

${ }^{351}$ Section 34 of the Māori Purposes Act 1950. 
appointing the Māori Trustee to be the agent of the owners for the purpose of this $\mathrm{Act}^{352}$

397. ...The Māori Trustee may, for any reason that he thinks sufficient, refuse to accept the application of any owner for a lease of land under this Part of this Act. ${ }^{353}$

Notions such as unoccupied, digiligent farming, diligent management or "used to proper advantage" of the land is subjective given it applies a western concept of land use. The express desire and drive for the Department of Māori Affairs was to bring allegedly unproductive and unoccupied lands into particular forms of production. ${ }^{354}$ The Māori Purposes Act 1950 was targeted in 1951 as the vehicle utilised to fulfil this goal. In the Report to the House of Representatives, the Minister of Māori Affairs pointed to the wider provisions under this Act that allowed the Māori Trustee to alienate lands. The Minister stated that

Part III of the Māori Purposes Act, 1950 has widened the Courts powers in dealing with unproductive lands, and with the drive for the development of unoccupied lands, particularly in the Waikato district, numerous applications have been made to appoint the Māori Trustee as agent for the owners to execute alienations of such lands. ${ }^{355}$

To support the 1953 Act and ensuring that unproductive Māori land was addressed, the Government passed the Māori Vested Lands Administration Act 1954, which linked unproductiveness and waste land by ensuring that Māori land remain productive in a prescribed manner. The 1954 Act stipulated that leasees of Māori land

cultivate use and manage all such parts of the said land as now are or shall hereafter be broken up and converted into tillage in a proper and husbandmanlike manner and will not impoverish or waste the same but will

\footnotetext{
${ }^{352}$ Part XXV, Section 387 of the Māori Affairs Act 1953.

${ }^{353}$ Section 397 of the Māori Affairs Act 1953.

${ }^{354}$ Chapter Five will discuss how "seemingly unoccupied" refers to Māori owners still living on the land but the land is still considered unoccupied.

${ }^{355}$ Ernest Corbett, 'Annual Report of the Board of Māori Affairs and of the Under-Secretary, Department of Māori Affairs, for the year ended 31 March, 1951', AJHR, G-09, 1951, p.12.
} 
keep the same in good heart and condition and will at the end or sooner determination of the term leave all such parts of the said land as shall be broken up in good permanent English grasses and clovers of the descriptions and in the proportions usually sown in the district [emphasis added]. ${ }^{356}$

This was reiterated in 1955, through the passing of the Māori Reserved Lands Administration Act. This legislation mirrored the Māori Vested Lands Administration Act 1954 word for word. Although the term 'waste land' was less utilized, particularly following the consolidation of the Waste Lands legislation in 1948 this term re-emerged as a means to ensuring any land lying in waste was utilised and maintained in a productive manner.

For whānau at Pokaewhenua, waste land was an unknown concept both in the 1860 s and 1950s. As the means for their livelihood and as a connection to their ancestors, th concept of waste or unutilized land was anathema to Ngāti Hine ki Pokaewhenua. Land at Pokaewhenua was one of the few remaining blocks left to Ngāti Hine and their primary means of sustenance. All possible use of cultivated and bush land was used as means to feed the whānau and given the idea of waste land was not a concept familiar to Te Ao Marama, there was no understanding from their perspective, of the policy or legislative criteria which applied to their whenua. Te Ao Marama and her whānau were using their land in their best interests and in a manner keeping with their livelihoods. It did not occur to them nor were they aware that their mode of living had been legislated against. $^{357}$

Despite this, the Minister for Māori Affairs continued to promote the productivity of Māori land. To add more confusion to those at Pokaewhenua, the Minister also referred to another provision that affected their continued occupation at Lot 512. The Minister's report in 1951 also referred to the provisions of the Māori Purposes Act 1950 Act as it applied to alienations where land was infested with what were defined as noxious weeds or subject to charging orders for rates. ${ }^{358}$

\footnotetext{
${ }_{356}^{35}$ Paragraph 8, Schedule 1, Maori Vested Lands Administration Act 1954.

${ }^{357}$ Ngawini Puru, Interview, 4 October 2011, Auckland.

${ }^{358}$ Corbett, 'Annual Report of the Board of Māori Affairs', p.13.
} 
The Department's process was clear in its intent: alienate through owners' meetings but where that fails, appoint the Māori Trustee to alienate on their behalf. The Minister of Māori Affairs in 1950, Ernest Corbett, clarifies the process stating in parliamentary debates that where Māori land had not been farmed or managed in the best interests of the owners and the public, the Māori Trustee be appointed as the agent to further alienate land. Corbett argues that

The Court may make an order appointing the Māori Trustee as agent to execute an instrument of alienation. ${ }^{359}$

Although Corbett goes to great pains to point out that alienation does not refer to the loss of title for Māori owners, under the 1953 Act the Māori Trustee had both the power and provisions to alienate title from Māori.

The 1953 legislation states that unproductive land exists when its Māori owners have "neglected to farm or otherwise manage the land with due diligence and that in consequence of their neglect the land is not being used to proper advantage". ${ }^{360}$ In the literature of that time, 'due diligent' farming is synonymous with "scientific farming" which utilises as it's foundation the ability to apply fertilisers, be trained in a recognised farm management course and the use of "modern equipment" such as tractors, haymakers, top dressing, transport facilities, and milking machines. ${ }^{361}$ The Department of Lands and Survey utilises this definition as its foundation for awarding Crown and private land to young farmers, which will be examined later, but in the meantime, Māori notions of land use are disregarded in the 1953 Act. The Lockean theory of land use and Pākehā notions of scientific farming specifically excluded the ability of some Māori to utilise their own land.

Unlike the 1800s where the criteria for alienating Māori land was implied, the 1953 Act and its associated policies were overtly clear. ${ }^{362}$ Māori land defined as unproductive was to be alienated. The process by which that alienation would take place was by

\footnotetext{
${ }^{359}$ Ernest Corbett, 'Māori Purposes Bill', NZPD, 29 November 1950, p.4726.

${ }^{360}$ Section 387(d) of the Maori Affairs Act, 1953.

${ }^{361}$ Department of Agriculture, 'Farming in New Zealand', pp.70-71.

${ }^{362}$ See section on Department of Māori Affairs.
} 
application to the Māori Land Court, which in some cases could simply involve a hand written letter of intent.

Once an application was made to the Court to utilise Māori land, particularly a block that was alleged to be unproductive, a preliminary investigation was undertaken that included District Officers (from the Department of Māori Affairs), a Noxious Weed inspector (from the local Council), confirmation of survey (through the Department of Lands and Survey), a valuation (from the Valuation Department), an assessment of current utilisation and possible future utilisation (also from the Department of Lands and Survey and Department of Māori Affairs) before a meeting of owners was summoned. Negotiations and discussion between the applicant and the Judge could take place before the proposal was put before the owners and the

the Crown's policy remained overwhelmingly biased towards those who were willing to sell. ${ }^{363}$

It is important to note that six steps involving five government agencies were undertaken before the owners of the land were notified that an application to alienate their land was being processed. The Māori Land Court, Department of Māori Affairs, Lands and Survey, Local Council and Valuation Department had discussed, assessed, valued and considered the use and alienation of land before seeking owners' input.

The key function of the Court was to determine the merit of an application and wherever possible, progress the aims of its legislated purpose. Judge K. Gillanders Scott, in an address to the University of Auckland in 1964 argued that the Māori Land Court's jurisdiction was limited to law guiding its practice

which in turn depends upon the mind of the Legislature wherein is reflected the public will [added emphasis] and the sociological and economic requirements of a progressive society. ${ }^{364}$

\footnotetext{
${ }^{363}$ Paul Husbands and Kate Riddell, 'The Alienation of South Auckland Lands', Waitangi Tribunal Research Series, Wellington, Ministry of Justice, 1993, p.21.

${ }^{364}$ K. G. Scott, 'The role of the Māori Land Court in Land Utilisation', Address given at the Leadership Conference, Kaikohe, 17 April 1964, p.3.
} 
Scott gives an insight into the workings of the Māori Land Court, as a current sitting Judge in 1964. Despite having a duty to assist Māori with the retention of their land and as "guardian of the Māori owners and Māori interests", there was also the administrative duty to exercise discretion based on

reason and sound sense so that substantive justice might be done according to all the circumstances of the case and according to what the law, which gives the Court its peculiar jurisdiction, might be. ${ }^{365}$

Scott's presentation details how the Māori Affairs Act of 1953 is administered in Court as it pertains to land utilisation and argues that the "overall authority of the Minister of Māori Affairs' common aim...is purely and simply the orderly and proper use of land"366, which is at odds with its other object of the retention of Māori land.

The process for applications to alienate land was fairly straight forward. Where multiply owned land of more than ten owners was under application, a meeting of owners (Part XXIII) is called to consider an alienation. A resolution to sell or lease is passed at the meeting and must be confirmed within six months after the owners' meeting. Those dissenting to the resolution can either object to the confirmation or apply to have their interests partitioned. Should an application to object be filed, this was heard by the Court who then makes a ruling. ${ }^{367}$

Judge Scott refers specifically to Part XXV in his presentation confirming that applications under this Part can be made by a local authority or by any other interested person. The Māori Trustee is appointed agent for the owners, only where

it is shown to the satisfaction of the Court, that the land is by ordinary and reasonable standards, capable of being used with advantage for agricultural or pastoral or horticultural purposes, or for the production of food products,

\footnotetext{
365 Ibid.

${ }^{366}$ Ibid, p. 7.

${ }^{367}$ Ibid, p. 10 .
} 
or for dairy farming or the keeping of pigs, bees, or poultry, or for a combination of any two or more of such purposes. ${ }^{368}$

In reality, and considering that long list, there was little else that could have been added. Judge Scott argued that there was no provision under the Act to presume that the Act promoted or practiced confiscation. Scott is emphatic and provides his definition of confiscation as

(i) to seize for the public Treasury;

(ii) to adjudicate to be forfeited to the public Treasury as in the case of the goods of a traitor;

(iii) to appropriate under legal authority.

In Scott's considered opinion, the Māori Affairs Act was designed "for the purpose of protecting and securing to the Māori his lands". ${ }^{369}$ It is likely Scott considered that the Act and by extension, the Māori Trustee, was obligated in some way to sell or lease only to a Māori or his descendant where that Māori had made a "suitable" offer to purchase or lease. ${ }^{370}$

Scott argued that his frequent use of Section 438 application to appoint a Trust or Trustee for the owners would act in their favour. Scott also argued that

if it so happens that an owner has a house on the land...there is ample provision in the law for fully protecting, and leaving quite undisturbed, that homesteader. The main thought should be to get the balance of the farm land into production under secure tenure. ${ }^{371}$

Sadly that was certainly not the case in Waikato and Chapter Five will show how these assumptions were misguided. More importantly however, Scott contradicts himself by

\footnotetext{
368 Ibid.

${ }^{369}$ Ibid, p.5.

${ }^{370}$ Ibid, p. 10.

${ }^{371}$ Ibid, p. 11 .
} 
insisting in that same address that idle Māori land must be put into production for the common good and Māori should sacrifice communally owned land for that purpose. Scott argues

Land just cannot be left to lie idle and neglected. Land must, of necessity, be used to best advantage, and it must be made to produce food...Production is necessary if we expect to have maintained the high standard of living that we in New Zealand enjoy. I fear that the desire and wish of many Maoris [sic] to own in severalty or in common small uneconomic and unused lands must be sacrificed for the good of the common weal. ${ }^{372}$

Judge Scott therefore argues that Māori-owned land used by whānau should be alienated if it is in the national interest to do so. For Scott, the Minister of Māori Affairs was the final lynch pin in Part XXV alienations as they required the Minister's final approval for land alienations. ${ }^{373}$

\section{Department of Māori Affairs}

The Department of Māori Affairs evolved out of the Native Department but was more organised, focussed in its policies and with more explicit collaboration with other agencies. A report to the Minister of Māori Affairs in 1957 gave a brief outline of the functions and activities of the Department. The key focus for Māori Affairs prior to 1929 was the

\footnotetext{
"acquisition of Māori lands by the Crown; the investigation of claims and grievances raised by petition to Parliament; work...evolving out of the Court and the Māori Land Boards;...promoting the well-being of the Māori people;... and numerous other functions...relating to Māori Affairs generally". 374
}

\footnotetext{
${ }^{372}$ Ibid, p. 12.

${ }^{373}$ Ibid, p. 10.

${ }^{374}$ Department of Māori Affairs, 'Minister of Māori Affairs', Report to Minister of Māori Affairs, 16 December 1957, AAMK, series 869, W3074/3, Archives New Zealand, Wellington.
} 
After 1929, the Department focused more so on the development of Māori land, with the help of the Māori Trustee who was amalgamated with the Department in $1934 .{ }^{375}$ The Māori Affairs Act 1931 was able to more easily facilitate the alienation and development of unproductive Māori land. The head of the organisation with administrative oversight was the Permanent Head who was both the Secretary and Māori Trustee.

Field officers were employed to deal with land settlement, housing and welfare, and were managed by District Officers in the region, of which there were six (Whangarei, Auckland, Rotorua, Gisborne, Whanganui and Wellington with a number of sub-offices in outlying areas). The Department had a Land Settlement division as well as a Titles and Claims division that dealt with Māori land issues. The Chief Judge and 6 District Judges were employed, as were Field Supervisors, Overseers, Foremen and Farm Managers (58 employees), Building Supervisors (47), Māori Welfare Officers (50) and Surveyors and Assistants (21). ${ }^{376}$

At the governing level, the Māori Affairs Board consisted of a member of the Executive Council, the Secretary to the Treasury, the Director-General of Lands, the Valuer General, the Director-General of Agriculture, three people appointed by the Governor General, the Minister of Māori Affairs and the Secretary of Māori Affairs. The Board had the responsibility for investments held by the Māori Trustee, the development and settlement of Māori lands and Māori land acquired by the Crown. ${ }^{377}$ Like any other departmental organisation of the government, the department was driven by the Board's decisions. $^{378}$

The primary function of the Department in the 1950s and 1960s as it pertained to land development and settlement was contained in Part XXIV of the Māori Affairs Act 1953. Part XXIV, in summation, seeks as its objective, Māori land development through either the occupation of Māori freehold land by Māori and/or through the use of Māori land for farming purposes (preferably by Māori). In contrast however, this part of the Act,

\footnotetext{
${ }^{375}$ Ibid.

${ }^{376}$ Ibid. See also G.P, Shephard, 'Annual Report by Under-Secretary for the year ended $31^{\text {st }}$ March, 1948', AJHR, Session I, G-09, 21 July 1948, p.4.

${ }^{377}$ Shepard, 'Year ended 31 March, 1948', p.4.

${ }^{378}$ Department of Māori Affairs and Māori Trust Office, 'A Brief Summary of the Activities of the Department and of the Māori Trustee’, Department of Māori Affairs, July 1984, p.14.
} 
through Section 335, also allows the Board to occupy Māori land and utilise it for any purpose under that particular part of the Act, as well as to nominate people to occupy the land or to lease the land. On close reading of this section, the Board is not only able to nominate people to utilise the block, but could also dispose of land so that it was utilised in a way the Board considered 'appropriate'.

In addition to improvements, the Board was able to fund such as draining reclaiming, roading, bridging, fencing, clearing, grassing, planting, topdressing, manuring, the erection of and repair of buildings, the Board was also able to purchase and sell equipment and livestock (and subsequently sell or dispose of them as they saw fit), and recouping improvement costs from lessees at the beginning of lease terms. The ability to utilise and improve Māori land deviated little from the 1931 Act mentioned above.

Part XXIV did give preference to Māori owners, but also reserved the right to refuse a Māori owner. Section 342 stipulated that

in the case of any particular area the Board is of the opinion that there is no Māori who, being ready and willing to become a lessee, is a fit and proper person to be a lessee of that land. ${ }^{379}$

This is a subjective statement, and one that had also carried over from the 1931 Act. $^{380}$ The importance of this subjectivity is that it had a direct impact on whether Māori were considered "suitable nominees" for rural lending by the department or suitable to undertake farming activities on the land. This will be discussed later in the chapter, but it is important to note at this juncture that the subjectivity of the legislation and the Board played an important role. In the meantime, the value judgement of who is fit and proper rested solely with the Board and its agents to determine.

In addition, the Department of Māori Affairs actively encouraged the public to utilise Part XXV, Section 387 which is evidenced in the Secretary for Māori Affairs advice to the General Secretary of the New Zealand Dairy Production and Marketing Board on 28 May 1962. The General Secretary was concerned with the leased farm blocks reverting

\footnotetext{
379 Section 342, Māori Affairs Act 1953.

${ }^{380}$ Section 24(3) of the Māori Affairs Act 1931.
} 
back to their Māori owners and going out of production. The Secretary suggested that the Māori Land Court require all Māori land to remain in full production by consolidating Māori land titles. ${ }^{381}$ The General Secretary argued that

if consolidation of Māori land titles is necessary to achieve the objective aimed at...then a workable basis for title consolidation should be devised and put into operation. ${ }^{382}$

Separate to this, an Interdepartmental Committee of Investigation was set up in 1960 that included the Department of Lands and Survey, Department of Agriculture and the Department of Māori Affairs. The Committee was established to consider a series of articles that appeared in the New Zealand Herald which had focused on the unproductive lands in the East Coast of the North Island. The Committee was tasked to inspect the land and determine whether it had deteriorated, the cause of the deterioration and to suggest ways to stop or reverse deterioration. ${ }^{383}$

Similarly worded letters complaining about unproductive land were also sent from Councils such as the Whakatane County Council to the Minister of Māori Affairs arguing that where owners were unable to rely on the government for assistance to develop their land, "they must look to other sources or surrender their lands to private enterprise". ${ }^{384}$ This differed little to Judge Scott, as previously mentioned.

As part of an overall review of land alienation, Māori Affairs undertook a survey throughout its regional offices to ascertain how land was being alienated, the total area per region and the overall sales price accrued. In 1964, the Hamilton office was able to advise that 1,880 acres had been alienated through the use of Part XXV/53 (1,247 by lease and 533 by sale), all to European farmers. Under Part XIX, other land alienated

\footnotetext{
${ }^{381}$ J K Hunn to General Secretary of the New Zealand Dairy Production \& Marketing Board, 28 May 1962, Māori Affairs - Head Office (AAMK) series 869, W3074/1153, Archives New Zealand (ANZ). 382 Ibid.

${ }^{383}$ Department of Māori Affairs, 'Report of Interdepartmental Committee of Investigation into Deterioration of East Coast Farming Land', 1960, Māori Affairs - Head Office (AAMK) series 869, W3074/1153, Archives New Zealand (ANZ), Wellington.

${ }^{384}$ D C Butler to Minister of Māori Affairs (J R Hanan), 30 May 1961, Māori Affairs (ACIH), series 16036, W2490/212, Archives New Zealand, Wellington.
} 
included 1,696 acres by lease to Pākehā and 3859 acres by sale also to Pākehā. ${ }^{385}$ Table 4 sets out those land areas alienated under Part XXIV and Part XXIII.

Table 4: Māori Land alienated in the Waikato District under the Māori Affairs Act $1953^{386}$

\begin{tabular}{|c|c|c|c|c|c|c|c|c|c|c|}
\hline \multicolumn{5}{|c|}{ Leases } & \multicolumn{6}{|c|}{ Sales } \\
\hline & \multicolumn{2}{|c|}{ To Europeans } & \multicolumn{2}{|c|}{ To Māori } & \multicolumn{3}{|c|}{ To Europeans } & \multicolumn{3}{|c|}{ To Māori } \\
\hline & No. & Area & No. & Area & $\begin{array}{l}\mathbf{N} \\
\mathbf{0}\end{array}$ & Area & $\begin{array}{l}\text { Considera } \\
\text { tion }\end{array}$ & No. & Area & $\begin{array}{l}\text { Considera } \\
\text { tion }\end{array}$ \\
\hline PT XIX/53 & 47 & 1696 acres & 9 & $\begin{array}{l}1026 \\
\text { acres }\end{array}$ & 77 & 3859 acres & $£ 191943$ & 5 & 99 acres & $£ 4524$ \\
\hline PT XXIII/53 & 5 & 378 acres & 5 & 535 acres & 17 & 1554 acres & $£ 63388$ & 1 & 47 acres & $£ 1168$ \\
\hline PT XXIV/53 & 10 & 1130 acres & 4 & 595 acres & & & & & & \\
\hline PT XXV/53 & 4 & 1247 acres & - & - & 3 & 533 & $£ 3780$ & - & - & - \\
\hline $\begin{array}{l}\text { Māori } \\
\text { Trustee }\end{array}$ & 1 & 1507 acres & - & - & 89 & 200 acres & $£ 139223$ & 4 & 1 acre & $£ 768$ \\
\hline
\end{tabular}

The value of Māori land differed depending on the Part of the Act utilised to alienate that land. Under Part XIX, land was sold for $£ 49.73$ to Europeans or $£ 45.69$ to Māori. Land sold under XXIII, was sold for $£ 40.79$ to Europeans or $£ 25.85$ to Māori. Land under XXV was sold significantly lower for $£ 7.09$ to Europeans with no land sold to Māori and land sold by the Māori Trustee was sold for $£ 696.11$ to Europeans or $£ 768$ to Māori. The value of Māori land will be explored later in this chapter, however it is important to make this point now to show the inequality of how Māori land was sold, particularly under Part XXV of the 1953 Act.

In essence, the department's policy during the 1950s-1960s was the productive use of Māori land at any cost. The use of national interest arguments to alienate land was influenced by Councils, farmers and the Department's desire to alienate Māori land lying idle. Richard Hill argues that

The Crown's 'basic policy' from the end of the 1940s...continued in fact to be that of 'public good' productivity. In this pursuit, even the Board of Māori Affairs paid scant regard to the desires of many Māori. ${ }^{387}$

\footnotetext{
${ }^{385}$ I.W. Apperley to Head Office, 22 January 1965, Māori Affairs (ACIH), series 316, W2490/69/4 PT2, Archives New Zealand, Wellington.

${ }^{386}$ Ibid.
} 
The underlying practice of Māori Affairs had not changed in any significant way since colonial settlement. With the creation of the Department of Māori Affairs (or Native Affairs at that time), what little impetus existed to protect Māori interests were eroded as settler desire for land, and the legislative processes created to administer, manage and define Māori ownership and interests were implemented to "ease the alienation of Māori land into European hands as speedily as possible". 388

In reality, the department's main aim was to Europeanise Māori and bring them into the national sphere of operating. This involved moving away from communal living and social structures with traditional ties to communally owned land. The aim was to remake Māori into individuals, with an individualistic outlook socially and economically so they could better assist the nation and the national interest. While Māori continued to look to their traditional ways, they were considered to be sitting apart from society, idle and unproductive. This is best exemplified in the Māori Affairs report to the House of Representatives in 1949, which argues that

An independent, self-reliant and satisfied Māori race working side by side with the Pakeha and with equal incentives, advantages and rewards for effort in all walks of life is the goal of the government. ${ }^{389}$

Peter Fraser, the Prime Minister, Minister of Māori Affairs and Chair of the Board of Māori Affairs also argued that Māori needed to "shoulder the responsibilities of citizenship as workers together with the Europeans in the economy of the nation", and this could only be done by individual pursuits and the occupation and production of Māori land, by Māori owners (as prescribed) or by Europeans who were better able to accomplish those goals. ${ }^{390}$

\footnotetext{
${ }^{387}$ Richard Hill, Māori and the State: Crown-Māori Relations in New Zealand-Aotearoa, 1950-2000, Wellington, Victoria University Press, p.30.

${ }^{388}$ Pearson, Dream Deferred, p.150.

${ }^{389}$ Peter Fraser, "Foreward by Minister of Māori Affairs', Annual Report of the Board of Māori Affairs and the Under-Secretary, Department of Māori Affairs for the year ended 31 March 1949, AJHR, G-09, 1949, p.2.

${ }^{390}$ Ibid.
} 
The notion of shouldering the responsibility of citizenship was echoed the following year by the Hon Ernest Corbett (new Minister of Māori Affairs), who argued that Māori needed to "make a full contribution towards that laudable objective through the use of their lands". 391 Corbett argued that

Land is the foundation of our prosperity and every land owner has a duty to see that full use is made of the soil. ${ }^{392}$

Corbett points to the Māori Purposes Bill (in 1949) as being purposefully designed to bring Māori lands into production. Corbett's sweeping statement regarding idle Māori land was to argue that Māori land was generally weed infested and "are of no benefit to the Māori people at all". ${ }^{393}$ This attitude is taken a step further. Allegedly idle Māori lands that were put into production through leases in the 1950s resulted in half the rentals received being deposited into a sinking fund rather than a third of the rentals as previously practiced. Corbett considered that given Māori had received nothing from their idle lands, "it will be no hardship to receive half the rent". 394

It seems that little thought was given to the impact further alienation would have on Māori who were living on the land. As Māori were evicted, whānau were incapable of providing a livelihood on their whenua for themselves. This was an underlying pervasive attitude throughout the Department of Māori Affairs, which was influenced by other government departments, Ministers and parliamentarians that shared a common goal in the production and utilisation of Māori land. For Waikato Māori however, the contents of the Māori Affairs Act 1953 was tantamount to confiscation. The provisions allowing, conversion, consolidation and occupied and utilised Māori land to be alienated for perceived unproductivity gave too much power to the Courts and the Māori Trustee and during its final reading in the House, the MP for Northern Māori, Tapihana Paikea argued that

\footnotetext{
${ }^{391}$ Corbett, 'Māori Purposes Bill', p.4728.

392 Ibid.

${ }^{393}$ Ibid, p.4722.

${ }^{394}$ Corbett, 'Māori Purposes Bill', p.4725.
} 
I have expressed the opinions held by my people when they first saw a copy of the original Bill. They said it was like confiscation and disinheritance. ${ }^{395}$

The push for productivity was extended further by the Leader of the Opposition, the Right Honourable Walter Nash, who argued that "land must be utilised for the benefit of mankind". ${ }^{396}$ So although Māori could not use their land for their own beneficial livelihood, their land could, and was used for the national interest and for the benefit of mankind.

Scrutiny by the New Zealand Māori Council bore no influence with the Department of Māori Affairs. In 1966, the New Zealand Māori Council requested information regarding the valuation of Māori land, designation of the land sold, its area, the sale price confirmed by the Court and any special considerations regarding its sale. ${ }^{397}$ As far as Māori Affairs was concerned they saw "no point in supplying the details of sales confirmed by the Māori Land Court". ${ }^{398}$ The Secretary of Māori Affairs (McEwen) argued

we don't think that the Council ought to attempt to put itself in a position to pronounce upon contracts which are the sole concern of the vendor and the purchaser, subject only to the confirmation of the Court. ${ }^{399}$

This is a bold statement, particularly given the contract presupposed an involvement of all Māori land owners in a block. More specifically as a Court of record, providing information as requested, could have been innocuous enough unless the department was seeking to restrict information or the process they utilised. A number of files remain sealed to this day for perceived confidentiality reasons. Attempts to access Lot 512A files from both Archives and the Māori Trustee are an example. Numerous attempts

\footnotetext{
395 Tapihana Paikea, 'Māori Affairs Bill', NZPD, 18 November 1953, p.2319.

${ }^{396}$ Walter Nash, 'Māori Affairs Bill', NZPD, 18 November 1953, p.2320.

${ }^{397}$ J.M. Booth to Secretary of Maori Affairs, 12 September 1966, Māori Affairs (ACIH), series 16036, W2490/212, Archives New Zealand, Wellington.

398 J.M McEwen to Secretary, 'Sales of Maori Land', New Zealand Maori Council Secretary, 21 September 1966, Māori Affairs (ACIH), series 316, W2490/69/4 PT2, Archives New Zealand, Wellington.

${ }^{399}$ Ibid.
} 
were also made to access the information held by the Māori Trustee without success. ${ }^{400}$ From this perspective, it would appear the department was accountable to itself solely or did not want to be accountable to others.

In addition to the Māori Land Court and Māori Affairs, the Māori Trustee also played a significant role with Māori Land. Before the Māori Trustee came into existence, its predecessor's, the Public Trustee and the Native Trustee also played a role in administering Māori land.

\section{The Public Trustee}

The Public Trustee was established in New Zealand in 1872 and was governed by a board of management that included the Colonial Treasurer, the Annuities Commissioner, the Attorney-General, the Commissioners of Audit and the Public Trustee. ${ }^{401}$ A key function of the Public Trustee was to manage the estates of minors, the deceased and "lunatics", whereby lands owned by these persons were vested in the Public Trustee. ${ }^{402}$

The Public Trust's administration of Māori land involved firstly native reserves beginning in 1877 and more formally following the enactment of the Native Reserves Act of 1882. Specifically, the Act allowed for the following:

8. All lands and personal estate now vested in the Governor or any Commissioner or public officer (as such) under any Act heretofore in force relating to Native reserves shall, from the commencement of this Act, be deemed to be placed in the Public Trust Office. ${ }^{403}$

Following the West Coast Commissions of Inquiry in 1880 and 1881, the Public Trust took over direct administration of the West Coast settlement reserves including

\footnotetext{
${ }^{400}$ Other files remain sealed including Whangamarino $442 \mathrm{~B} 1$ and C, Sections 160, 84 and 86, Lot 323B1 and $\mathrm{BC} 262,471 \mathrm{~B}, 471 \mathrm{~A} 1,512 \mathrm{~B}, 210,323 \mathrm{~B} 2 \mathrm{~B}, 512 \mathrm{~A} 2,512 \mathrm{C}, 241 \mathrm{~B} 1$ and B2, 242B1, 393B1, B2, G1, G2A and B, C, D, E, H, J, and K, 234E, 309, 277, 314, 313, 299A, 233L to name a few.

${ }^{401}$ Ralph Johnson, 'The Trust Administration of Māori Reserves, 1840-1913', Rangahaua Whanui National Theme L, Wellington, Ministry of Justice, 1997, p.104.

${ }^{402}$ Ibid.

${ }^{403}$ Native Reserves Act 1882.
} 
exchanging, leasing or selling those reserves. ${ }^{404}$ Although monies from leases were provided to the owners, the Public Trust had the statutory authority to lease those lands in perpetuity without a requirement to consult its owners. ${ }^{405}$

The process utilised by the Public Trustee allowed the government to access Māori resources and develop and settle Māori land within the parameters of their land development schemes without the requirement to consult with or consider Māori interests, particularly given the Public Trustee was under no obligation to do so. ${ }^{406}$ The Public Trustee's primary objective was promotion and settlement and Kieran Schmidt and Fiona Small argue that

In legislating the role of the Public Trustee, the Government legislated for itself. The legislation allowed reserved lands to be transferred to the Trustee, who then became their legal owners. The Government could then control reserve lands without the problem of dealing with multiple owners. ${ }^{407}$

The utilisation of the Public Trustee's ability to lease land in perpetuity allowed the Government access to large tracts of Māori land, at peppercorn rates without the burden of progressing applications through the Native Land Court.

By 1912, Māori dissatisfaction with the Public Trust was articulated in the Commission of Inquiry into West Coast Settlement Reserves. The Trust's statutory obligation to consult with Māori owners was seen as inadequate and the interests of the lessee were predominant in its dealings. The Inquiry found in favour of the owners and unlike the perpetuity leases, recommended that the lands be returned to their Māori owners. ${ }^{408}$

The Public Trustee shared a pervasive underlying attitude with the Māori Affairs Department and its Ministers: that Māori were incompetent. The Trust's response to the Inquiry was to argue that the return of land to Māori was "calamitous" not only to Māori

\footnotetext{
${ }^{404}$ Johnson, 'Trust Administration', pp.100-108.

${ }^{405}$ Ibid, pp. 108.

${ }^{406}$ Kieran Schmidt and Fiona Small, 'The Māori Trustee: 1913-1953', Report for the Crown Forestry

Rental Trust, 1996, p.6.

${ }^{407}$ Ibid, p. 12

${ }^{408}$ Ibid, p. 16
} 
themselves but to the district where the land was situated. ${ }^{409}$ This underlying attitude was shared also by the Trustee's officers who "had taken up a position antagonistic to his beneficiaries". 410

The Public Trust was replaced by the Native Trustee under the Native Trustee Act 1920 who assumed the administration and management of native reserves and estates of deceased Māori or Māori with disabilities. As with the Public Trustee, the Native Trustee was tasked with collecting rents from perpetuity leases and distributing them to its owners.

\section{The Native Trustee}

The Native Trustee was governed by a Board that included the Native Minister, a member of the Executive Council (native or half-caste), the Native Trustee, the UnderSecretary for Native Affairs, the Under-Secretary of Lands and an appointment by the Governor General. ${ }^{411}$

Like the Public Trustee, the Native Trustee was also able to provide loans to Māori farmers, or more specifically against Māori land, a facility that had been absent despite loans being available to Pākehā farmers through the Advance to Settlers Account and the Department of Lands and Survey. ${ }^{412}$ However much like the Public Trustee, the Native Trustee failed to follow up with Māori land owners and after some time, the Native Trustee invested unclaimed monies until a Committee in each Māori Land Court district was set up to properly divest those funds to its owners. ${ }^{413}$

As with the Public Trustee, the Native Trustee inevitably began to ignore the interest of Māori land owners and with a continuing and pervading paternalistic attitude toward Māori owners, the Native Trustee fell back on a Public Trustee practice of failing to assist Māori, and instead sought "to assimilate [Māori] into the modern world" and

\footnotetext{
${ }^{409}$ Ibid.

${ }^{410}$ Macintosh \& Hosking in Kieran and Small, 'Māori Trustee', p.17.

${ }^{411}$ Section 10, Native Trustee Act 1920.

${ }^{412}$ Schmidt and Small, 'Māori Trustee', p.88.

${ }^{413}$ Ibid, pp.88-89.
} 
therefore saw no reason to consult with Māori land owners in the administration of their land. $^{414}$

In 1921, the Native Trustee changed its name to the Māori Trustee and in 1939 was amalgamated with the Department of Māori Affairs.

\section{The Māori Trustee}

The Māori Trustee had extraordinary powers, some of which transcended even the Public Trustee in its ability to acquire, lease or sell Māori land or convert uneconomic shares into its own name for redistribution to a deserving farmer. The Māori Affairs Act of 1953 gave these extraordinary powers to the Māori Trustee and by virtue of its name should have advocated for Māori as its Trustee in matters concerning their land. This was not the case.

By 1939, the Māori Trustee was under the auspices of the Department of Māori Affairs, as was the Māori Land Court. The Māori Trustee was responsible for the development and settlement of Māori lands, as well as advances for housing for Māori and when directed, the acquisition of Māori land by the Crown. ${ }^{415}$ The key powers and functions of the Māori Trustee were:

a) The administration of the estate of deceased Maoris [sic];

b) The administration of the property of Maoris [sic] subject to disability - minors, mental patients and so on;

c) The control and alienation of lands comprised in various trusts - the Māori reserves, the Māori vested lands, the Māori townships, trusts for the disposition of land under Court orders and so on;

d) The execution of instruments of alienation as agent of the owners of Māori land;

e) The collection and distribution of rents and other moneys arising from the alienation of Māori land;

\footnotetext{
${ }^{414}$ Ibid, pp.93-94.

${ }^{415}$ Department of Maori Affairs, 'The Minister of Maori Affairs', 16 December 1957, Maori Affairs (AAMK), series 869, W3074/3, Archives New Zealand, Wellington.
} 
f) The investment of trust moneys held in the Common Fund;

g) The assistance of Maoris [sic] and descendants of Maoris [sic] with advances from the General Purposes Fund;

h) The operation of the Conversion Fund. ${ }^{416}$

Of particular interest is "the execution of instruments of alienation as agent of the owners of Māori land”. A heading in a departmental report to the Minister of Māori Affairs notes in particular, their primary function with regard to alienation, and I include it in full:

\section{Agency for Alienation}

38. In respect of the disposition of Māori land in the ordinary course, the Māori Trustee becomes the statutory agent of the owners to execute instruments in accordance with resolutions passed at meetings of assembled owners. From this arises a good deal of the work relating to the collection and distribution of moneys.

39. In a special way, the Māori Trustee is appointed agent of the owners under Court orders to arrange alienations of Māori lands which are lying idle and unproductive or are covered with noxious weeds or in respect of which rates are not being paid. The essence of the system of alienation is that the land shall be leased and shall not be sold except in special circumstances. ${ }^{417}$

The importance or "specialness" that the Department of Māori Affairs placed through its agent, the Māori Trustee, on the alienation of Māori land was not inconsistent with its primary functions. A key function of the Māori Trustee was to either administer or alienate Māori lands. The Māori Trustee had as a priority, the ability to alienate Māori land due to land idleness or non-productivity.

\footnotetext{
${ }^{416}$ Ibid.

${ }^{417}$ Ibid.
} 
The Māori Trustee in the Waikato did not evolve beyond its predecessors nor did it consult Māori owners given it too was not required to do so. Although presumably created to act in the best interests of Māori, the Māori Trustee, like its forebears, ignored their mandate and instead acted in the best interest of the Government by utilising Māori land for its own economic benefit, regardless of Māori desires to farm their own land, or lease their land at intervals more suited to them. The Māori Trustee was also able to alienate any Māori land it saw fit. In the end, the Māori Trustee, like the Public Trustee sought to transfer through alienation, the use of Māori land from its Māori owners to Pākehā settlers and farmers.

Kieran and Small argue that the Māori Trustee was not an agent set up to benefit Māori land owners but instead a creation of the Government to simplify its access and administration of Māori land. They argue a three pronged process by which the Māori Trustee collaborated with the Government as follows:

(1) The Māori Trustee was a legislative creation - through its legislation, the Government controlled the institution and by doing so controlled the administration of Māori land.

(2) Utilising the Trustee allowed for a more simplified process of dealing with Māori land. As the "sole legal owner of reserves and estates" the Government didn't have to deal with multiple owners and administrators which "allowed customary land tenure to be assimilated into a European land tenure system".

(3) Māori were not considered capable of managing their own affairs or their land. More importantly, Māori were also not considered capable of making underutilised or "idle lands productive", therefore allowing the Māori Trustee to act on Māori land owner's behalf. ${ }^{418}$

In summation however, the Trustee's aim was to serve

${ }^{418}$ Schmidt and Small, 'Māori Trustee', p.152. 
the interests of European settlement [which] overrode even the right of Māori to obtain commercial income from their remaining lands. The Public Trustee was required to serve the interests of settlers rather more than those of the owners of the land held in trust. ${ }^{419}$

Perhaps a description of the role of the Māori Trustee is better left to the Parliamentary Report on Māori Affairs in 1960 which stated that

under the Māori Trustee Act the [Māori Trustee] has the normal functions of estate administration, much as the Public Trustee possesses under the Public Trustee Office Act, under the Māori Affairs Act and related Acts, he is called into service wherever it is necessary to find a substitute for multiple ownership. Doubtless the law would regard all his diverse capacities as being fiduciary in nature, but those acquired outside his own Act seem more administrative than fiduciary in essence. From the variety of duties entrusted to the Māori Trustee, it could be inferred that the Legislature has long since come to regard him as the appropriate custodian and conservator of the assets of Māoridom wherever one is needed. ${ }^{420}$

There are some issues with this statement, particularly given it assumes the Trustee's alienation of Māori land is in the best interests of Māori. It is doubtful that the fiduciary element of the Māori Trustee's duty is to ensure that Māori land is brought into production given the significant costs to bring idle land into production and the small lease returns those lands gave to Māori. There is certainly nothing in this statement that Māori labelled as rebels in the 1860s, living on a reservation set aside specifically for rebels and continuing to be stigmatised in the 1960 s would consider positive.

With the Māori Trustee working in tandem with the Native Land Court, Māori found it difficult to reinvigorate the productiveness they had previously enjoyed on their land, and seldom had the opportunity to participate in its development. In order for Māori to be considered suitable or capable of managing their land, criteria determined by the

\footnotetext{
${ }^{419}$ Ward, Unsettled History, p.154.

${ }^{420}$ Scott, 'Land Utilisation', p. 3.
} 
Department of Lands and Survey needed to be met, and it was this criteria that the Māori Land Court and Māori Trustee held Māori too.

\section{Department of Lands and Survey}

The purpose of the Department of Lands and Survey was to ensure that the land was transformed from a "haphazard land of impermanence into a "neat", "civilised" nation". ${ }^{42}$ Tracey Anderson argues that the premise behind the surveying of New Zealand was in line with

the colonial ideal of "civilisation" - particularly through European preoccupations with demarcation, permanence and fixity. ${ }^{422}$

The Department of Lands and Survey (Lands and Survey) was established in 1858 with the primary purpose of "surveying, subdivision, settlement and administration of Crown Lands". ${ }^{423}$ Prior to that however, a Surveyor General was appointed as per the Instructions to Hobson in 1839 , to divide the colony into counties (1,600 square miles), hundreds (100 square miles) and parishes (25 square miles) as well as reporting to Governor Hobson those lands to be used for roads, towns, villages or recreational areas. $^{424}$ Other peripheral responsibilities included the formation and construction of roads as a means of opening up Crown Lands for Settlement from 1876-1902 as well as agricultural oversight. $^{425}$

Prior to the Department of Lands and Survey, the office of the Colonial Secretary was responsible for Crown Lands until 1853 when this responsibility passed to the provinces. ${ }^{426}$ The practice of surveying Māori land in the 1860s and 1870s was through private surveyors whose practice was variable and its price doubly so. The use of private surveyors was discontinued in 1876 with the establishment of the Lands and Survey Department however a central examining board was not set up till 1888, with a

\footnotetext{
${ }^{421}$ Tracy Anderson, 'Living on the Boundaries: Fred Mace and Surveying in Nineteenth-century New Zealand', Graduate Journal of Asia-Pacific Studies, 2, 2, 2004, pp.65-6.

422 Ibid, p.66.

${ }^{423}$ Department of Lands and Survey, 'Introduction', AJHR, Session I, C-01, 1958, p.5

${ }^{424}$ MacLachlan, 'Land Administration', p.5.

${ }^{425}$ Department of Lands and Survey, 'Introduction', p.5.

${ }^{426}$ Ibid.
} 
central Board of Examiners established under the Land Act of $1892 .{ }^{427}$ Until then, Māori land that was surveyed bore the burden of high survey costs with charges or liens applied to the land.

As a result of the diverging provincial surveying policies, the previous Land Acts were consolidated in 1877 to create a standardised process of dealing with surveying and land administration. ${ }^{428}$ The administration of these lands were specifically targeted for settlement and development and the Surveyor General's activities up to 1876 was to ensure that lands acquired were partitioned to provide town and rural blocks for exmilitia and existing or newly arrived settlers. ${ }^{429}$

From 1886-1893 Lands and Survey was also responsible for Agriculture until a separate Department of Agriculture was established in 1893. Despite this, farm development including identifying underutilised and unproductive Crown and Māori land continued to fall within its purview. Lands and Survey had the responsibility of designing and controlling farms in New Zealand and as a part of its surveying function, also determined what contracts, settlement and development were progressed based on its recommendations. ${ }^{430} \mathrm{~A}$ key factor in progressing land development was the use of scientific farming which included the use of

modern machinery and farming techniques, coupled with an understanding of the mineral deficiencies of the soil of the region. ${ }^{431}$

This remained a key component of Lands and Survey until the establishment of Land Corp Farms in 1987.

Lands and Survey played an integral part in Māori land development and utilisation and much like the Native Land Court, surveyors were not required to be qualified in the field until 1888. The main requirement to become a surveyor was to be able to "satisfy

\footnotetext{
${ }^{427}$ Lawn, 'Surveyors', p.19.

${ }^{428}$ Department of Lands and Survey, 'Introduction', p.5.

${ }^{429}$ Lawn, 'Surveyors', p. 19.

${ }^{430}$ Mr Cooksley, 'Imprest Supply Bill, NZPD, Vol 299, 10 April 1953, p.27.

${ }^{431}$ Department of Lands and Survey, 'Introduction', p.6.
} 
the Chief Surveyor or Provincial Surveyor... of their ability to perform such work". ${ }^{432}$ Lands and Survey undertook two steps in the Māori Land Court processes and procedures which involved the actual surveying of Māori land blocks and land assessment for farming.

In 1953, the Director General of Lands and Survey was appointed to the Board of Māori Affairs and given its integral part in the process, also contributed to the direction and policy formation of the Māori Land Court including the oversight of new Māori land development projects in the 1950s, as agent for the Board of Māori Affairs. ${ }^{433}$ In the 1800s, this influence was far more direct. Although Lands and Survey was established in 1876, the Secretary General, Secretary for Crown Lands (who at that time administered the confiscated land in Waikato) and the Register's Office were all directly responsible to and overseen by the Executive Council. ${ }^{434}$

A key development driver for Lands and Survey was facilitating access for young farmers on to farm land. In a Centennial booklet printed for the Department in 1976, Lands and Survey argued that the

Development of large areas of farm land for eventual settlement of young landless farmers is an important task for the Department. ${ }^{435}$

The focus on young farmers followed the settlement of over 3,500 ex-servicemen following World War II. ${ }^{436}$ From 1961, Lands and Survey "was geared to the young, working farmer anxious to make a start of his own". ${ }^{437}$ The criteria ascribed to the "young landless farmer" was described as:

a) being at least 25 years of age;

\footnotetext{
${ }^{432}$ C.A Lawn, 'Surveyors Big Role in New Zealand History' Journal of the Auckland Historic Society, 8 , 1966, p. 17.

${ }^{433}$ Department of Maori Affairs and Maori Trust Office, 'Brief Summary', p.53.

${ }^{434}$ See Land Information New Zeaaland Family Tree 1840-2006 at http:/www.linz.govt.nz/sites/default/files/about-linz/organisation/our-whakapapa/linz-history-chart.pdf, downloaded on 4 November 2013.

${ }^{435}$ Department of Lands and Survey, 'The Department of Lands and Survey: 1876-1976', Wellington, Department of Lands and Survey, 1976, p.7.

${ }^{436}$ Ibid, p.9.

${ }^{437}$ Ibid.
} 
b) had 12 months prior experience in farming; and

c) been trained in a farm management course. ${ }^{438}$

The criteria for this type of farmer plays a significant role in Chapter Five, but it establishes early on the experience required to access underutilised or unproductive lands as well as the funds necessary to develop them.

Lands and Survey was also able to provide finance under the Marginal Lands Act 1950 which gave Pākehā farmers an advantage over their Māori counterparts who were restricted within Māori Affairs' departmental vote, by officials who were predisposed to fund individual Māori farmers rather than multiply owned Māori farms. ${ }^{439}$ Lands and Survey actively provided finance "for the new settler over and above a deposit calculated on a percentage of the total ingoings - that is, the value of land implements and stock". ${ }^{440}$ This finance equated to up to $90 \%$ of the cost of improvements and up to $75 \%$ for stock, equipment or plant. ${ }^{441}$

Lands and Survey provided loans to settlers of a varying type and following a Royal Commission of Inquiry into the Sheep Industry in 1950, the Marginal Lands Act was passed to assist farmers to restore, maintain and increase production on properties that were potentially economic. ${ }^{442}$

\section{Marginal Land Board Funding}

The Marginal Lands Board fell within the Lands and Survey purview and the Board members consisted of the Minister of Lands, the Director General of Lands, the Secretary to the Treasury, the Director General of Agriculture, the Chairman of the Soil Conservation and Rivers Control Council, with two others appointed by the Governor

\footnotetext{
${ }^{438}$ Department of Lands and Survey, Land Development in New Zealand, Welllington, Department of Lands and Survey, 1979, p.14. See also Department of Lands and Survey, Land Settlement Scheme: Crown Farms for Allotment by Ballot, Department of Lands and Survey, 1977, p.2, and from 1976 onwards, the criteria increased so that all applicants must have five years farming, training in husbandry and farm management, Advanced Trade Certificate in farming, and an appropriate Diploma from either Massey or Lincoln. See Department of Lands and Survey, Land Settlement Scheme: Crown Farms for Allotment by Ballot, Department of Lands and Survey, 1974.

${ }^{439}$ Ernest Corbett, 'Imprest Supply Bill', NZPD, 10 April 1953, p.9.

${ }^{440}$ Lands and Survey, 'Lands and Survey', p.9.

${ }^{441}$ Ibid, p. 22.

${ }^{442}$ Department of Lands and Survey, 'Activities of the Department of Lands and Survey', Wellington, Department of Lands and Survey, 1977, p.10.
} 
General. $^{443}$ The Board appointed Marginal Land Committees in each of the land districts, the membership of which included an officer from Lands and Survey, an officer of the Department of Agriculture and an appointment by the Commissioner. ${ }^{444}$ Wherever a Committee was established, a Marginal Land Panel was also created consisting of five members who were "experienced in farming or management of marginal lands". 445

The Department's focus of making uneconomic land productive is outlined as a priority and the Marginal Lands Act states that the functions of the Board "shall be to assist farmers to restore, increase and maintain production on marginal lands". 446 The Department argued that

the availability of finance from the Act means that formerly uneconomic land is being brought into use. As a country dependent on agriculture, this is a benefit to us all. ${ }^{447}$

The use of the Marginal Land Act and its associated Board and Committees, focused not only on Crown land or private land purchased by the Crown, but also Māori land developed through the Department of Māori Affairs. The primary objective of the administration of these lands was to increase productivity to benefit the country's exports particularly after the agricultural slump of the 1950s, by lending to Pākehā farmers utilising either Crown or Māori land. As mentioned above, this fund was not easily accessible to Māori, if at all.

The country's reliance on agriculture and the slump in agricultural exports in the 1940s played a key role in New Zealand's overall economy. The government's commitment to the Food for Britain campaign saw New Zealand's contribution to the Second World War, not only through its soldiers but also through dairy products and meat. ${ }^{448} \mathrm{~A}$

\footnotetext{
${ }^{443}$ Section 3, Marginal Lands Act 1950.

${ }^{444}$ Section 4, Marginal Lands Act 1950.

${ }^{445}$ Section 5, Marginal Lands Act 1950.

${ }^{446}$ Section 12, Marginal Lands Act 1950.

${ }^{447}$ Department of Lands and Survey, '1876-1976', p.8.

${ }^{448}$ Fraser, 'Annual Report...31 March 1949', p.2.
} 
statement issued by Britain's Ministry of Food stated that New Zealand's obligation was to contribute food to the war effort as a first priority. ${ }^{449}$

These pressures to ensure the effective utilisation of land were for the country's economic benefit and the benefit of its historical ties with Britain. Lands and Survey played a vital role in ensuring that the surveying of economic land blocks and their effective use was undertaken from its inception. According to Lands and Survey

[t]he Department, through its administration of the land policies of successive Governments, has made its full contribution to the settlement and development of New Zealand. ${ }^{450}$

Unlike funding provided by Māori Affairs, the funding criteria of the Marginal Land Board differed widely. Under Māori Affairs, a Māori farmer needed to prove a capability to farm and the ability to repay loans, as well as the criteria required by Lands and Survey.

The Marginal Land Board funding however was based on "good character", a subjective and vague notion that lends itself to inconsistency and a lack of transparency. How that character is measured is not overtly clear, but Corbett sought to clarify the criteria for funding by arguing that

The advances are made primarily on the character and the ability of the farmer only secondary consideration being given to his actual financial stability. ${ }^{451}$

Furthermore, the range of activities the Marginal Land Board was able to fund, was exhaustive. It included the clearing of any scrub, bush, or timber, cultivation and improvement of pastures, the purchase of plants or trees for shelter, conservation or improving the soil, the eradication of pets and noxious weeds, the erection or repair of fences, electricity or telephones services, construction of drainage or irrigation,

\footnotetext{
${ }^{449}$ J.V.T Baker, 'War Economy: Food Crisis in Britain', The Official History of New Zealand in the Second World War 1935-1945, Wellington, Historical Publications Branch, p.490.

${ }^{450}$ Lands and Survey, 'Lands and Survey', p.7.

${ }^{451}$ Corbett, 'Imprest', p.10.
} 
buildings of any description for the operation of the farm, yards or pens, provision of roads to access the farm, the purchase of any equipment or materials for water supply or efficient working of the farm, wages for the farmer or labourers, contractors and

the doing of any act, the carrying out of any works, and the expenditure of any money which, in the opinion of the Board, will result in the developing, restoring, or maintaining of the farm. ${ }^{452}$

In addition to the above, applicants were also eligible for refinance based on farm earnings or proceeds from the sale of livestock. ${ }^{453}$ In comparison, the Māori Purposes Act 1950 set out how Māori land could be alienated if it was considered marginal or unproductive. There were no provisions set out to assist Māori farms in 1950, nor in the Māori Purposes Act 1949 (which focused on housing and riotous behaviour), Māori Purposes Act 1948 (social advancement), Māori Purposes Act 1947 (health, education and welfare), 1946 (law amendments), 1945, 1944, 1943 (an offence to "remove or attempt to remove from any Native land any timber trees, timber, or other wood, or any flax, kauri-gum, or minerals" ${ }^{454}$ ), or the Māori Purposes Act 1942 ( $£ 50$ for the promotion of health, education, or moral, physical, or social welfare". ${ }^{455}$ The outline for farming assistance to Māori is however, found in the Native Land Amendment Act 1936 whereby the Act allows for the following:

(3) The Board may cause to be undertaken and carried out in connection with any land that is subject to this Part of this Act such works as it thinks fit, including (but without in any way limiting the Board's powers hereunder) the survey, draining, reclamation, roading, bridging, fencing, clearing, grassing, planting, top-dressing, and manuring of the land, the construction, provision, insurance, maintenance, and repair of buildings and other erections, machinery, water-supplies and other services, and any other works calculated to improve the quality or utility of the land.

\footnotetext{
${ }^{452}$ Section 12(2), Marginal Lands Act 1950.

${ }^{453}$ Section 12(3), Marginal Lands Act 1950.

${ }^{454}$ Section 6, Māori Purposes Act 1943.

${ }^{455}$ Section 4, Māori Purposes Act 1943.
} 
(4) For the purposes of this Part of this Act the Board may from time to time purchase or otherwise acquire on behalf of the Crown tools, plant, machinery, and other equipment, and may provide camps and buildings for the use of workmen, and may from time to time sell or otherwise dispose of any such tools, plant, machinery, equipment, camps, or buildings

(5) The Board may from time to time purchase or otherwise acquire on behalf of the Crown live-stock to be depastured on land that is subject to this Part of this Act, and may from time to time, as it thinks fit, sell or otherwise dispose of any live-stock or the produce or increase thereof. ${ }^{456}$

The key difference in Native land legislation and the Marginal Land Board was its focus on assistance. By 1964, the Marginal Land Fund had granted 934 loans amounting to $£ 4,188,711$. With the Marginal Land Fund, assistance was provided for farmers to farm on marginal land, however for Māori land, prescriptive measures were set out and the Board of Native Affairs (at that time) had the right to either allow its owners to farm, or quite separately, to lease out Māori land so that someone better able could do so. More importantly, assistance for the purchase of items under the Native Land Amendment Act was for the Crown's use - not necessarily for the Māori owners. This suggests then that assistance was for Crown controlled farms on Māori land that was either managed by or for Māori, again not necessarily assistance directly to Māori.

One of the agencies aligned to and initially a part of the Department of Lands and Survey was the Valuation Department who determined the value of Māori land.

\section{Department of Valuation}

The valuation of land, waste or Māori land in the nineteenth-century was determined by the Lands Department or a native land purchase officer. Valuation of lands was haphazard at best and undertaken by private surveyors. ${ }^{457}$ A systematic assessment of valuation did not occur in New Zealand until 1905, while prior to then there existed no legislative measures to set minimum prices and those offered to land owners were often

\footnotetext{
${ }^{456}$ Section 9, Native Land Amendment Act 1936.

${ }^{457}$ Richard Boast, Buying the Land, p.322.
} 
set by the private sector, or in the case of Māori land, the lowest price possible for profitable onward sale. $^{458}$

As mentioned in Chapter Three, waste land was purchased from Māori owners for between 1 penny to $£ 1$ per acre. Boast argues that the Crown paid 4 s for land in the Maniapoto region and refers to Stout and Ngata in 1907 stating that

In practice the Crown brought on its own terms; it had no competition to fear; the owners had no standard of comparison in their midst. ${ }^{459}$

During the nineteenth-century the sale of land, confiscated or otherwise, was the primary vehicle for paying back the loan acquired to invade the Waikato and for colonisation. The prices set against the land varied depending on how the land was classed and when it was sold. In 1866, lots north of the Whangamarino Stream were first advertised for $£ 25$ for 5 acres (or $£ 5$ per acre) by the Waste Lands Office, to $£ 15$ for 50 acres (or $£ 0.30$ per acre) in $1868 .{ }^{460}$

Although the Crown was required to purchase land at prices fixed by law, Māori land under the Native Land Settlement Act 1907 was classified into four classes and the prices still remained relatively low in comparison to general land. First class unimproved Māori land was valued at $£ 4$ and above, second class land valued at $£ 2-4$ pounds and third class land as $£ 2$ or less. ${ }^{461}$

In general, Māori land has been undervalued and although market or government valuations were legislatively required, "structural problems with Māori land values remained (and, indeed continue to be a problem)."462 Fifty seven years on, land categorised as unimproved Māori waste land sold in the national interests had only risen

\footnotetext{
${ }^{458}$ Ibid.

${ }^{459}$ Robert Stout and Apirana Ngata, 'Native Lands and Native-Land Tenure (Interim report of the Commission appointed to inquire into the Question of )', $A J H R$, Session 1, G-01, 21 January 1907, p.4.

${ }^{460}$ New Zealand Herald, 'Waste Lands Office: Whangamarino Creek, North Side', Volume III, Issue 832, 12 July 1866, p.2 and Daily Southern Cross, 17 July 1868, Volume XXIV, Issue 3433, p.2.

${ }^{461}$ Section 14(7)(c), Native Land Settlement Act 1907.

${ }^{462}$ Boast, Buying the Land, p.324.
} 
by $£ 3$ in 1964, while Country sections classified as General land sold for an average of $£ 40.72$ an acre. $^{463}$

So although the surveying and valuing component of the Department of Lands and Survey legislatively required minimum values and processes, these did not automatically transfer to Māori land and as will be seen in the following chapter, evidence suggests that the valuing of Māori land did not improve in the Waikato.

Those lands that were set aside as requiring development was determined by officers in the Department of Agriculture which set out the farming policies and expertise for the continued productivity of land.

\section{Department of Agriculture}

The Department of Agriculture was established in 1892 with the amalgamation of the Stock and Agricultural Branches of the Department of Crown Lands. ${ }^{464}$ The aim of the department was to provide farmers with advice and to improve the "quality and quantity of production". 465 The department focused predominantly on settler development of Crown land through perpetual leases or freehold titles held by settlers themselves.

Prior to 1892, agricultural oversight fell within the purview of the Department of Crown Lands in the form of the Stock Branch in 1875, a dairy instructor in 1883, Agricultural Branch in 1885, appointment of a Minister of Agriculture in 1890 and the Department of Agriculture in $1892{ }^{466}$

The primary activity in the first 20 years of the Department was to subdivide some of the original large estates that had been acquired by settlers during the first land purchases, "bringing virgin land into production" and applying a more scientific

\footnotetext{
${ }^{463}$ New Zealand Yearbook, 1964 see

http://www3.stats.govt.nz/New Zealand Official Yearbooks/1964/NZOYB 1964.html\#idchapter 1802 10 downloaded on 1 July 2013.

$\overline{464}$ Tony Nightingale, White Collars and Gumboots: A History of the Ministry of Agriculture and Fisheries, 1892-1992, Palmerston North, Dunmore Press Ltd, 1992, p.9 and Department of Agriculture, Farming in New Zealand, Wellington, Hutcheson, Bowman and Stewart Ltd, 1950, p.69.

${ }^{465}$ Ibid, p.9.

${ }^{466}$ Ibid, p.32.
} 
approach to farming that included fertilisers, grasses and minerals such as lime. ${ }^{467}$ The use of machinery from the 1920s was also significant. Previously back breaking work, the use of horse drawn teams to break in land had been used but with the introduction of tractors and haymakers, top dressing, transport facilities, milking machines and home separation for butter and cheese, a greater rate of production across the agricultural industry emerged. ${ }^{468}$

Settler land development was largely successful due mainly to the land available and the increasing sizes of farms. By 1890 however, despite 20 million acres in production, the ability to better and profitably utilise existing holdings required differing methods of farming that moved away from overstocking and scrub burning which had ruined farmland particularly in the South Island. ${ }^{469}$ Tony Nightingale, Historian with the Department of Internal Affairs in the 1990s, argues that scientific farming through the use of exotic grasses, the application of scientific principles pertaining to plant management, the use of fertilisers and alternative farming techniques to assist greater production levels and advanced machines, was the preferred method for progressing greater production. ${ }^{470}$

However, this increased production produced variable results which saw the government intervene by assisting with the creation of cooperatives to ensure a consistent and hygienic standard of meat and dairy products for export. ${ }^{471}$

The 1892 Dairy Industry Act gave government the ability to take legal proceedings against those farmers that failed to reach appropriate export standards. By the 1900s New Zealand was the leading exporter in dairy production to Britain, ${ }^{472}$ which was followed by the Dairy Industry Act 1908 that regulated the

\footnotetext{
${ }^{467}$ Department of Agriculture, Farming in New Zealand, p.69. See also Tirikatene, E.T, 'Imprest Supply Bill', NZPD, 10 April 1953, p.30 who argues that scientific farming is playing a vital role in greater production.

${ }^{468}$ Department of Agriculture, Farming in New Zealand, pp.70-71.

${ }^{469}$ Nightingale, White Collars, p.32.

${ }^{470}$ Ibid, p.21 and 41.

${ }^{471}$ Ibid, pp.46-50.

${ }^{472}$ Ibid, p. 45.
} 
production, collection, treatment, preparation, and manufacture under proper sanitary conditions of all dairy produce intended for sale for human consumption within New Zealand or for export. ${ }^{473}$

The Department of Agriculture was heavily influenced by British needs during the 1920s and 1940s. While trying to establish a thriving farming economy and recover from a crippling depression that pushed agricultural prices down, international demands played havoc with the agricultural industry in New Zealand. With resources already stretched and farmers working within rations, dwindling fertilisers, labour shortages, as well as rising costs and protectionist measures by Britain in the 1920s, exports from New Zealand suffered.

\section{International Pressure to Feed Britain}

In 1939, bulk purchases by Britain of meat, wool and dairy products required a focus on increased production locally. In 1940, Britain's Ministry of Food asked New Zealand to increase its exports in cheese requiring the industry to convert current production methods to suit. ${ }^{474}$ So from an earlier concentration on wool and meat, New Zealand had moved from meat, to cheese, then butter and back to cheese again, showing a willingness by the government to acquiesce to British needs and consequently requiring farmers to comply to meet those needs. ${ }^{475}$

The influence of Britain should not be understated. New Zealand exported the great majority of its agriculture products during settlement until the 1950 s to Britain. In the five year period to 1947 , the Department of Agriculture calculated that $80 \%$ of New Zealand's butter exports, $93 \%$ of cheese and $74 \%$ of meat, went to Britain. ${ }^{476}$

From colonial settlement, New Zealand relied on the reciprocal relationship with Britain. The bulk-purchase agreements prior to, during and after the war period, where all New Zealand agricultural products were exported to Britain, were a direct result of

\footnotetext{
${ }^{473}$ Department of Agriculture, 'Farming in New Zealand, p.279.

${ }^{474}$ Department of Agriculture, Farming in New Zealand, p.73 and Nightingale, White Collars, p.189.

${ }^{475}$ G.R Hawke, The Making of New Zealand, Cambridge, Cambridge University Press, 1985, p.169.

${ }^{476}$ Department of Agriculture, Farming in New Zealand, pp.287-288.
} 
fulfilling British interests, while local farmers and the public in general remained on strict rations. $^{477}$

In 1953, this pressure was also present and the government saw its part in feeding a hungry world as its contribution to world security. ${ }^{478}$ For Corbett, the more food New Zealand produced, the more farms in production, the more New Zealand tied itself to Britain's cause and economy. Corbett argued that

every effort was bent by our Administrators to strengthen the basic economy of New Zealand. We realise that in these days great stress is laid on security in all its phases, and we realise that in the production of food for a hungry world we can contribute to security to a marked degree by increasing the productivity of our farm lands. ${ }^{479}$

The MP for Wairarapa, Bertie Cooksley, shared similar sentiments noting in particular that New Zealand was "important as a food producing country". ${ }^{480}$ Cooksley saw the growing population and the need to produce food as a contribution New Zealand could make for the "sake of the world at large [and] for the welfare of our own country and its prosperity". ${ }^{481}$ This international focus required all land, General and Māori, to become more productive.

In addition to overseeing land production, the Department of Agriculture was also responsible for the control of noxious weeds as a result of the importing of various exotic plants during early colonial settlement. In 1900, the Noxious Weeds Act was passed giving county councils local responsibility to manage noxious weeds, while still retaining powers within the department to intervene where councils were inadequate in stopping its spread. ${ }^{482}$ More importantly, the Department of Agriculture assessed noxious weeds on Māori land and were able to determine whether this qualified as a means for alienating land to avoid continued spread.

\footnotetext{
${ }^{477}$ Department of Agriculture, Farming in New Zealand, pp.285-286.

${ }^{478}$ Corbett, 'Imprest', p. 10.

479 Ibid.

${ }^{480}$ Cooksley, 'Imprest Supply Bill', p.28. See also Ernest Corbett, 'Māori Affairs Bill', NZPD, 18 November 1953, p.2301.

${ }^{481}$ Cooksley, 'Imprest Supply Bill', p.28.

${ }^{482}$ Nightingale, White Collars, p.96.
} 


\section{Noxious Weeds}

Although, the oversight of communally owned Māori land remained within the Department of Māori Affairs, the Noxious Weeds Act provided two schedules listing weeds to be eradicated on sight and wherever the councils deemed it necessary. ${ }^{483}$ Inspectors of noxious weeds were devolved from the Department of Agriculture to local councils, town boards or road boards within a district. These inspectors had the authority to issue notices to land owners to remove weeds and if owners failed to comply, inspectors could charge owners with an offence against the Act. ${ }^{484}$

Most of the noxious weeds listed in the schedules of the Act were plants imported during settlement, or native plants considered a nuisance to grazing. Councils played a vital role in the management of noxious weeds. It was on their say so and also their sufferance as to whether the schedules were enforced. In 1930, the Councils had the sole power to determine whether to apply the provisions of the Act and if applied, the council also had the ability to seek funding, on the farmer's behalf, to have the weeds removed. Nightingale argues that

Councils could declare all or none of the of the scheduled weeds on their lands noxious. ${ }^{485}$

It was near impossible to eradicate noxious weeds and with discretion in the hands of Control Officers in the local Council, the outcome was inconsistent, biased and subjective. Unlike General land, noxious weeds on Māori land were set down as criteria for alienation despite $78 \%$ of Māori land being weed free, as opposed to $56 \%$ of General land. $^{486}$

\section{Inequality of land protection}

It is clear from government policy and its application in its range of agencies, that Māori property rights failed to have the same protections as their European counterparts.

\footnotetext{
483 Ibid.

${ }^{484}$ Section 5(7), Noxious Weeds Act 1950.

${ }^{485}$ Nightingale, White Collars, p.97.

${ }^{486}$ G. Rosenberg, 'Māori Land Tenure and Land Use: A Planner's point of view', The Journal of the Polynesian Soceity, 75, 2, June 1966, p.214.
} 
Despite Treaty of Waitangi assurances under Article Two, the practice of confiscation in the 1860-70s and the application of the Native Land Court and Public Trustee clearly illustrates that Māori interests were superfluous to settler interests and land productivity. This did not abate in the 1900s. Property rights of freehold tenure were articulated by the Minister of Finance, Joseph Ward, in 1909 by stating that

[e]very man who now owns a freehold is entitled to it, and under no conditions would the State be justified in taking any step to weaken his freehold tenure. $^{487}$

This unjustified taking of freehold tenure principle appears to apply only to General land and not land owned individually or collectively by Māori. This is also exemplified in Pākehā access to loans and finance to improve their existing farms or buy into new leases, whereas their Māori counterpart had limited finance options through the Māori Trustee or slim to no options through private lenders.

The preference towards Pākehā settlers in the 1800s continued into the 1960s. Lockean attitudes towards land use and the facilitated sale and alienation of land by Māori Affairs and its subordinate agencies (Māori Land Court and Māori Trustee), show a concerted and collaborated approach to alienating Māori land. This alienating of unproductive Māori land is unjustified and Rosenberg argues that in the greater totality of land utilisation in New Zealand, Māori land did not deserve the attention it received. ${ }^{488}$ The notion of the 'land stealing court' ending in 1909 is incorrect. The practice of the $1800 \mathrm{~s}$ is mirrored in the $1950 \mathrm{~s}$ and $1960 \mathrm{~s}$, albeit with a couple of minor name changes. The end remains the same. Māori land was confiscated for settler development and progress in the 1800 s and for the public good or national interest in the 1950s-60s.

\section{Conclusion}

The agents responsible for the alienation of Māori land culminated with the Māori Land Court and the Department of Māori Affairs but were assisted by the Māori Trustee, Departments of Lands and Survey, Agriculture, and Valuation. This chapter described

\footnotetext{
${ }^{487}$ Joseph Ward, 'Supply', NZPD, 10 November 1909, p.xvii.

${ }^{488}$ Rosenberg, 'Planner's point of view', p.215.
} 
the intersecting nature of these agents of alienation which was seen through the governing body of the Department of Māori Affairs, the oversight by its Board, in the practices of the Māori Trustee and Māori Land Court, the department itself, its collaboration with the Department of Lands and Survey through the rendering of their services, and also the complicity seen with local Councils and the Department of Agriculture.

The legislation guiding these agents all spoke a common language: that the production of land, particularly Māori land was in the national interest and that all measures should be utilised to get those lands into a particular type of production. Notions of productivity, national interest, noxious weeds and the subjectivity by which these notions were applied were mono-cultural in their application. Māori were not seen as part of the national interest, nor was their mode of production valued.

International pressure to increase production and feed the hungry in Europe had a significant impact on the way New Zealand organised its economic activity, at the cost of both Māori and non-Māori. Britain's Food for Britain campaign through the use of bulk purchase agreements directed that New Zealand bring into production every possible acre of land. Unfortunately, although a review in 1960 argued that there was more European land lying idle than Māori land, there was a targeted practice of ensuring that Māori land be administered by one of the agents of alienation to remove Māori management of those lands and then put them into greater production by a person capable of doing so, utilising scientific methods of farming.

Māori did not fall into this category, at least not Māori in Waikato. As a region prized for good rainfall and idyllic grasses, extra attention was placed on Waikato and although elsewhere the lease of Māori land to one of its Māori owners was more common place, this was less likely in Waikato, particularly in Ngāti Hine.

The next chapter will demonstrate how all these factors combined into the alienation by sale and lease of a Māori land block that was returned to landless rebel Māori following the invasion of Waikato. As a confiscated block returned to its customary Māori owners, this block was alienated again to bring it back into a particular form of production in the national interests. 


\section{CHAPTER FIVE: KI PŌKAEWHENUA - LOT 512}

Nōku tēnei whenua. Ahakoa keria he rua kotahi maero

te hohonu, e rima maero te whānui, nōku tēnei whenua.

This is my land. Even if you dig a hole a mile deep and five miles wide, this is my land. ${ }^{489}$

While Tāwhiao was on a hîkoi around the country, the Native Lands Minister, John Bryce, set about encouraging Maniapoto and Waikato to utilise the Native Land Court. Tāwhiao was already wary of the way the Court was administrating Māori land and in 1882 requested that Bryce cease all surveying, roading, leasing and selling of or on Māori land. ${ }^{490}$ Tāwhiao argued

Ko te ruri, ko te reti, ko te hoko, ko te mahi rori, me te Kooti Whakawa Whenua Māori o te Takiwa ki a matou ko nga Rangātira me o matou iwi me mutu inaianei. Taihoa ano e mahi, kia oti rano te whakarite a te Paremata me nga Rangatira Maori o te taha ki oku iwi etehi tikanga hei whakahaere mo te taha ki nga Pakeha me nga iwi i raro i au e kiia nei he Kingi.

Let the work of surveys, let leasing, let sales, let the making of roads and the Native Land Court in the district which belongs to me and the people of my tribes, be stopped for the present. Shortly they may be commenced, when the Parliament and the chiefs of our people have agreed upon some mutual basis of settlement between the Europeans and those people who, under me, are called the King Party. ${ }^{491}$

Tāwhiao argued with Bryce on a number of occasions to let him oversee the administration of land in Waikato, but on all accounts was turned down. ${ }^{492}$

\footnotetext{
${ }^{489}$ Tāwhiao, 1883 in Turongo House, Tāwhiao, p.156.

${ }^{490}$ Turongo House, Tāwhiao, p.147.

${ }^{491}$ Te Wheoro, as directed by Tāwhiao to present to Parliament, Turongo House, Tāwhiao, p.147.

492 Turongo House, Tāwhiao, pp.148-9.
} 
On 2 February 1883, while Tāwhiao was in the Wellington area, Bryce ordered the Government steamer, Stella, to enter Kāwhia at night and anchor in the harbour. The following morning, surveyors began to draw up the township while the ship's captain "marked the channel with buoys for the first time". ${ }^{493}$ On being told of the steamer and surveyors in Kāwhia, Tāwhiao gave his tongikura:

Nōku tēnei whenua. Ahakoa keria he rua kotahi maero te hohonu, e rima maero te whānui, nōku tēnei whenua.

This is my land. Even if you dig a hole a mile deep and five miles wide, this is my land. ${ }^{494}$

To add insult to injury, Bryce refused to pay the anchoring money which would have meant acknowledging Tāwhiao's mana whenua at Kāwhia, further cementing Tāwhiao's deep held mistrust of the government and Pākehā in general. ${ }^{495}$ In a memo Bryce presented to Parliament, he clearly set out his stance on the government's intrusion into Kāwhia harbour, by stating that

They [Waikato Māori], correctly assumed that the occupation of a township at Kawhia, and the marking out of the channels of the harbour without Tawhiao's permission being asked or obtained, was an assertion of the Sovereign rights of the Queen without any recognition of the pretentions of the Māori potentate. ${ }^{496}$

This was a deliberate provocation by Bryce, particularly given Kāwhia was a Waikato stronghold and according to Waikato and Tāwhiao, it was

acquired by illegal and deceitful methods and they could not understand how it could be allowed. Once it seemed the Government had gained a

\footnotetext{
${ }^{493}$ Turongo House, Tāwhiao, p.156.

${ }^{494}$ Tāwhiao in Turongo House, Tāwhiao, p.156.

${ }^{495}$ Ibid.

${ }^{496}$ John Bryce, 'Memorandum by the Native Minister on the Opening of Kawhia Harbour, and on the recent establishment of a Constabulary post in that Locality', $A J H R$, Session 1, G-01, 16 October 1883, 1884, p.1.
} 
foothold on any soil of Waikato, they used it only as a base to eat up the remaining lands. ${ }^{497}$

To retaliate, Tâwhiao instructed that Bryce's beacons be cut down, the landing buoys destroyed, and the survey pegs pulled up. However, once Bryce established a constabulary at Kāwhia, Tāwhiao met with Bryce to preserve peace and to lodge his objections which were ignored further. ${ }^{498}$

For Ngāti Hine, 1883 was a significant year for confirming their land ownership in the Lake Waikare area. Two significant pā, Pōkaewhenua and Takapūruharuha had been awarded (by the Native Assessor) to be areas for those Māori still living there ${ }^{499}$.

This chapter is the case study for this thesis and describes in detail the alienation of Lot 512 in the Parish of Whangamarino. By drawing on key themes in previous chapters, this chapter shows how the enduring values of colonisation and the government agencies responsible for land alienation, culminated in the facilitated alienation of Lot 512. Before proceeding to the alienation of these blocks, an outline of the creation of the Parish, the settlement of Pākehā and existing occupation by Ngāti Hine is described as a backdrop and also to draw together the threads of the Ngāti Hine story that have been at the forefront of each chapter to this point. This chapter explores the descendants of those Ngāti Hine who were at Rangiriri in 1863 and their ongoing struggle to maintain ownership of their land in Waikare in general and Pōkaewhenua in particular. Although Ngāti Hine existed within its own hapū boundaries, from a Pākehā point of view they were living within the Parish of Whangamarino.

\section{Parish of Whangamarino}

The Parish of Whangamarino was created as early as 1868 and is bounded by the Maramarua Parish to the north, Hapuakohe ranges to the east, the Waikato River to the west and the Parish of Taupiri to the south. Although no records survive of its exact date of creation, or any Gazette notice establishing its boundaries, the Parish of

\footnotetext{
497 Turongo House, Tāwhiao, p.157.

${ }^{498}$ Bryce, 'Kawhia Harbour', p.1.

${ }^{499}$ George Wilkinson, to Under Secretary, 23 October 1890, Lands and Survey Office (BAAZ), series 1108, 58a, Archives New Zealand, Auckland.
} 
Whangamarino encompassed 512 blocks in 1914 and contains 95,776 acres of land in total.

The northwestern boundary begins in Meremere at the confluence of the Whangamarino and Waikato rivers. The northern boundary follows an easterly course along the Whangmaarino River and other tributaries until it reaches the Hapuakohe Ranges, at Pukekamaka. It then follows the confiscation line of 1865 southward down to the Matahuru Stream before heading westerly, skirting along the southern end of Lake Waikare before dipping south to Tahuna Road, across to Ohinewai and the Waikato River. The western boundary is the Waikato River from Ohinewai to Meremere. A map of the Parish and key areas of interests are outlined in Map 1 on page 22a.

The Parish was a result of survey processes designed to provide administrative boundaries so that local government could apportion land blocks for settlement. ${ }^{500}$ Little is written about the establishment of Parishes in New Zealand however Felix Wakefield in writing to the Directors of the New Zealand Company concerning regulations for public surveying and the disposal of public lands in 1840s New Zealand, points to the establishment of survey maps that accurately reflect the boundary lines of Counties, Baronies, Parishes and Townlands. ${ }^{501}$ Wakefield states that the maps include the detailed features of cities, market towns and villages with a view to the localities of 32 natural and artificial features, including parish churches, parks, farms, creeks, canals, docks, bridges, harbours and quarries "with a view to the most rapid and prosperous colonization of this vast territory". 502

Wakefield, as a surveyor in England, borrowed heavily from the English and Irish practice of surveying. Parish boundaries were utilised in the Auckland District with instructions from the Secretary of State for War and Colonies, Lord Normanby, to Captain Hobson in 1839 to

divide our said colony into districts, counties, hundreds, towns, townships and parishes...to divide and apportion the whole of the said colony into counties each of which shall contain, as nearly as may be, 40 miles square,

\footnotetext{
${ }^{500}$ Felix Wakefield, Colonial Surveying with a view to the Disposal of Waste Land: In a report to the New Zealand Company, London, J W Parker, 1849, p.75.

${ }^{501}$ Ibid.

${ }^{502}$ Ibid, p.1.
} 
and to apportion each county into hundreds, of which each hundred shall, as nearly as may be, comprise an area of one 100 square miles, and again to subdivide each hundred into parishes, of which each parish shall, as nearly as may be, comprise an area of 25 square miles. ${ }^{503}$

Although a number of small parishes were established in Auckland (35 by 1865), the Parish boundary of Whangamarino is significantly larger.

The Parish contains a significant part of the Waikato economic production as well as the main road and waterways used as trade routes to the Auckland market economy both across to the Waikato River as well as through Kaiaua. The Parish's importance was such that it contained flour mills and the main transport lines for the region. The labour force adapted from local production for whānau and hapū consumption, to feeding the international market in the early $1800 \mathrm{~s}^{504}$

The written history of Whangamarino however focuses predominantly on non-Māori settlement and land grants. The most complete history of the Waikare area is covered in Sherson's book, Kahikatea, Cabbage Trees and Koromiko, where an in-depth history is provided of the first pioneers in Waerenga, Okarea and Taniwha. Little is written about Māori living there, however Sherson provides a timeline of events from a Pākehā perspective from the 1870s to 1910s, which provides an account of Pākehā settlement in the area.

The first pioneers in the vicinity were military settlers who were awarded 50-acre blocks and six months worth of rations. At least once a month, military settlers were required to undertake drills and remain well armed to manage "hostile Maoris [sic]". 505 As compensation, settlers were provided with a stipend as remuneration for their drills and as a standing militia. ${ }^{506}$

In 1884 , the area between Waerenga and Okarea was surveyed including Jamieson Road where Pōkaewhenua is situated. By 1883, the first two sections in Okarea were sold, both being 300 acres in size. Additional blocks around Jamieson Road were sold

\footnotetext{
${ }^{503}$ Marquis of Nomandy to Captain Hobson in Alexander MacKay, A compendium of official documents relative to the Native Affairs in the South Island, Volume 1, Nelson, Luckie and Collins, p.5.

${ }^{504}$ Hargreaves, 'Māori Agriculture'.

${ }^{505}$ C. Sherson, Kahikitea, Cabbage Trees and Koromiko, pp.16-17.

${ }^{506}$ Ibid, p. 17 .
} 
in 1888 as settlers purchased and/or extended their existing land holdings. One particular family (James Ross) ended up with 4,000 acres in Okarea. ${ }^{507}$ A school was erected in 1912 which serviced the settler families in the area, but excluded Māori until the late 1940s. ${ }^{508}$

As farming enterprises invested in the area, ownership by non-residents became apparent. One Australian businessman owned 3,000 acres in 1888 that was managed by a local farmer as well as a Scottish immigrant who had become a member of the Provincial Council and owned a 600 acre block in Waerenga, as well as other farms in the Waerenga area. ${ }^{509}$

\section{Early Māori land use and occupation}

The Parish of Whangamarino was inhabited by a number of hapū including Ngāti Hine, Ngāti Marae and Ngāti Naho. Other hapū such as Ngāti Mahuta married into Ngāti Hine and settled in Waikare, forming a strong identity in the area. ${ }^{510}$ Most of these hapū shared common ancestry or associated hapū ancestry as well as links to neighbouring iwi groups such as Hauraki, who claimed a cross-border occupation particularly in the Eastern Waikato area. ${ }^{511}$

Land use was for local whānau and hapū livelihoods, but also included significant trade with Auckland, consisting of pigs, goats, a range of vegetables and fruits, timber, grasses, wheat, flour and seafood including fish. As was seen in Chapter Three, this trade was significant for Ngāti Hine and the whānau in Waikare who utilised resources as far north as Kaiaua and exchanged readily with other hapū along the Waikato River and elsewhere. ${ }^{512}$

The occupation of land while focused in Pōkaewhenua also extended to other seasonal mahinga kai areas, such as Kaiaua, Waikare, Matahuru and Rangiriri, for traditional food sources. ${ }^{513}$ Food production within the Parish included horticulture, agriculture,

\footnotetext{
${ }^{507}$ Sherson, Kahikatea', p.46.

${ }^{508}$ Ngawini Puru, Interview, 4 October 2011, Auckland.

${ }^{509}$ Sherson, Kahikitea, pp.60-61.

${ }^{510}$ Moko Tauariki, Presentation, ,19 October 2013, Rangiriri Pā.

${ }^{511}$ Waitangi Tribunal, The Hauraki Report, Wellington, Legislation Direct, 2006.

${ }^{512}$ Moko Tauariki, Presentation, 19 October 2013, Rangiriri Pā.

${ }^{513}$ Ngawini Puru, Interview, 4 October 2011, Auckland.
} 
fishing including fresh and seawater, hunting, gathering and trapping. The kainga nohoanga were Tangoao, Takapūruharuha, Pōkaewhenua and Kaiaua. ${ }^{514}$

Trade with missionaries and settlers was common in the Parish, but the great majority of the local produce was taken to the markets in Auckland. Trading in the interior of the Parish was focused more between hapū or negotiated through missionaries, where travel was more difficult and whānau were less tolerant with outsiders. ${ }^{515}$

For Ngāti Hine, the Parish boundaries were non-existent. Local Māori were unlikely to have been involved in the drawing up of survey or boundaries lines and it was apparent at the close of the invasion of Waikato that the presence of surveyors in Waikato produced confusion amongst Māori. ${ }^{516}$

Those hapu within the Parish boundaries operated according to resource allocations based on familial rights and connections. These hapū boundaries were not based within or on the Parish boundaries created by external surveyors.

However, demand for land in Whangamarino was evident as early as 1853 when a government purchase officer sought to acquire land around Waerenga but was turned away by a number of Waikato Rangatira because a tapu (or rāhui) lay over the lands from Lake Waikare to Thames. ${ }^{517}$ Another government purchase officer was prevented from entering into Whangamarino the following year, after unsettling Waikato in the area given his visit was unannounced and unwelcomed, and the officer appeared to be agitating for land sales. ${ }^{518}$

When physical attempts to enter into or purchase land in the Waikato failed, the use of government policy quickly followed. In 1858, without representation by iwi, the government introduced policy as a means to "assert control over [Native] affairs" and to "facilitate the voluntary acceptance by the Natives of English institutions". 519 In doing so Parsonson argues that

\footnotetext{
514 Ibid.

${ }^{515}$ Parsonson, 'Tainui Claims', p.14.

${ }^{516}$ Ibid.

${ }^{517}$ Ibid.

${ }^{518}$ Ibid, pp.14-15.

${ }^{519}$ Parsonson, 'Tainui Claims', p.32.
} 
There was no mistaking settler assumption of the right to determine the shape of the Māori future. ${ }^{520}$

As early as May 1864 before the end of the Waikato invasion, there was speculation on land availability for the militia and others within the Whangamarino boundary. ${ }^{521}$ Surveyors had followed quickly behind the Crown's forces and measured out and surveyed land in Waikare and Ngāruawāhia for military settlers six years after the battle of Ōrākau. ${ }^{522}$ On 12 July 1866, the first land blocks were advertised for sale on the northern side of the Whangamarino Creek by public auction and by 1868 land in the "Parish of Whangamarino" was advertised in the Daily Southern Cross. ${ }^{523}$ Between 1868 and 1927, 73 blocks were made available to both loyal and rebel Waikato Māori in the Parish, accounting for 6,663 of the 95,776 acres. The remaining 439 blocks or 89,113 acres were provided as land grants for military servicemen or sold by open tender to settlers and immigrants. ${ }^{524}$

In releasing blocks for Crown grants, the government had determined preferred alienees and reported against disposals in the $A J H R$. In 1873, lands disposed of in the Waikato listed preferred alienees as military settlers, Waikato immigrants, Natives (loyal) and Natives (other). As per the colonial world view it is not surprising to see ex-rebels labelled under a non descript "other" category as it identifies how most Waikato Māori were seen at the time. In 1873, 675,999 acres were apportioned to the alienees across the Waikato region including Whangamarino. 525

The land apportioned to ex-rebels in 1883 was considered poor by Pākehā standards and was mostly either barren hills covered in fern or mountainous bush land. ${ }^{526}$ As a condition of a Crown grant, the Government engaged Native Officers to assess land suitable for returned rebels. One of the conditions for land grants was that ex-rebels maintain continuous occupation on land granted to them with a stipulation that an

\footnotetext{
520 Ibid.

${ }^{521}$ Daily Southern Cross, 'Whangamarino', Volume XX, Issue 2124, 11 May 1864, p.4.

${ }^{522}$ Parsonson, 'Tainui Claims', p.178.

${ }^{523}$ Daily Southern Cross, 'Preemptory Sale of Country Land and Surburban Lots', Volume XXIV, Issue 3440,25 July 1868, p.2.

524 This data is based on Archive New Zealand and Māori Land Court database information, cross referenced with newspaper advertisements.

${ }^{525}$ J. H St John, 'Report on Confiscated Lands' in 'Further Papers Relative to Confiscated Lands', $A J H R$, Session 1, C-04b, 12 August 1873, p.4.

${ }^{526}$ George Wilkinson, 'Reports from Officers in Native Districts [In continuation of G.-1, 1882]', AJHR, Session I, G-01, 11 June 1883, p.3.
} 
absence from the land for two years, could result in forfeiture back to the Crown for reallocation. The intent of this section was to ensure that rebels remained on the land granted to them by the Crown and separated as far as possible from Kingitanga strongholds so as not to provide ongoing support to the Kingitanga. Section 7 of the Waikato Confiscated Lands Act, 1880, specified that

If, for a consecutive period of two years, such grantees or their descendants shall cease to use such land as their domicile, the grant, thereof may, by Order in Council, be declared forfeited.

Should Māori not take up the grant identified and provided for them, or leave the land grant for a period of two years their rights or titles to the land were "effectively annulled as if the same had been repealed by scire facias, ${ }^{527}$ and the land comprised therein reverted to the Crown". 528 This stipulation was confirmed by a Native Officer, George Wilkinson, who was assigned to the Whangamarino Parish and evidence provided later in this chapter will show it was later applied in the Parish. ${ }^{529}$

George Wilkinson was tasked with assessing lands identified for rebels and in doing so, concluded that had the land available to them been "of good or even fair average quality", there was more likelihood Māori would have moved on to the land and occupied and farmed it. ${ }^{530}$ In reality, the land was poor and often some distance from their previous nohoanga, negating the land grants provided. For hapū like Ngāti Hine who were provided land grants within their takiwā, there was less resistance, in the main however, land grants were in areas that were remote and away from their support systems and the Kingitanga. ${ }^{531}$ Wilkinson argued that

the failure of endeavours during the last 14 years to get ex-rebels of the Ngātihaua [sic] tribe to desert the king and occupy the Tauwhare Block, near Hamilton, which they originally owned. ${ }^{532}$

\footnotetext{
${ }^{527}$ According to the Oxford Dictionary, scire facias is a writ requiring a person to show why a judgement regarding a record or patent should not be enforced or annulled.

${ }^{528}$ Section 7, Waikato Confiscated Lands Act 1880.

${ }^{529}$ Wilkinson, 'Native Districts Continuation', p.3. See Lot 277 as an example on pages 211.

530 Ibid.

531 Ibid.

532 Ibid.
} 
Few incentives existed for Māori to take up land grants from the Crown in Whangamarino. The Crown provided poor land to Māori in exchange for loyalty to the colony. This was a difficult decision for Ngāti Hine who as co-defenders at Rangiriri in 1863 were already adversely affected by the invasion and then secondly, having lost their livelihood. Ngāti Hine were then required to build a stationary life on land without the resources across Waikare to which they were accustomed.

Those iwi and hapū eligible for compensation were identified in the New Zealand Settlements Act 1863 as Loyal Māori, whereas those identified under the Waikato Confiscated Lands Act, 1880, were defined as being in rebellion. Loyal Māori were either compensated monetarily and then later in land grants from the Crown (see Chapter 4), while those identified as rebels, followed a similar process but as mentioned previously, were required to sign declarations admitting to their rebellion before being eligible for monetary payments initially and then later compensated in land. In the main however, rebel Māori were labelled landless by virtue of their exclusion in the first land grants offered to Māori, and their lower status in the hierarchy of preferred alienee.

In 1900, a list of landless Māori was published in the AJHR including Ngāti Hine and Ngāti Marae of Waikato, and lands set aside for their use were identified throughout the Waikato.

\section{Landless Native blocks in Whangamarino}

There were 19 blocks listed in the AJHR in 1914 that were set aside as "sections reserved for Waikato Natives". These blocks were the final remnants of Crown land promised to Waikato Māori that had yet to be investigated and granted through the Native Land Court to previously identified rebels. The blocks for Ngāti Hine were situated in the Whangamarino Parish under the provisions of

the New Zealand Settlements Act, 1863 and its amendments and the Waikato Confiscated Lands Act 1863 and its amendments of 1882 for the use of exrebels, under certain conditions of occupation. ${ }^{533}$

\footnotetext{
${ }^{533}$ M. Gilfedder and H Haszard to A. de Brito Savile, 'Commission of Inquiry in Regard to the Existing Reserves for Landless Natives in the South Island and in the Waikato-Maniapoto Native Land Court District, and as to the Disposition thereof', AJHR, Session 1, G-02, 31 August 1914, p.5.
} 
A report by the Commission of Inquiry in Regard to the Existing Reserves for Landless Natives in the South Island and in the Waikato-Maniapoto Native Land Court District, to the House of Representatives in $1914^{534}$ did not however take into account block investigations that were already underway in the Native Land Court. Although these lands were set aside for ex-rebels, there were other mechanisms that could be used to free these lands up by the Department of Lands for disposal as ordinary Crown lands which included lands being unoccupied or reserves where "nothing has been done". 535 For the Crown, it was expected that Māori would cultivate the lands returned to them and in doing so, settle permanently in those areas, rather than return to areas that remained strong holds for the Kingitanga. As mentioned previously the Waikato Confiscated Lands Act of 1880 set out the requirement that continuous occupation was necessary or land grants forfeited as punishment.

It was hoped that forcing Waikato Māori to continuously occupy Crown grants would inevitably stem and then halt the flow of support to the Kingitanga. This forced occupation did not take into consideration cultivations that were planted on more fertile neighbouring lands, or mahinga kai practices that often utilised a land block as a base, but had whānau travelling between localities to procure food and other resources. ${ }^{536}$

In addition to these stipulations, restrictions were also put in place "to prevent sale or mortgage" as it was believed by Government agents that Māori were predisposed to sell the land immediately upon receiving title. This intent is also covered in the Waikato Confiscated Lands Act of 1880 as follows:

6. Any grant which the Governor is authorized to make under the provisions of this Act as aforesaid shall make the land therein comprised absolutely inalienable.

Land grants awarded by the Governor General to rebel Māori under the Waikato Confiscated Lands Act 1880, were for those

\footnotetext{
${ }^{534}$ Gilfedder and Haszard 'Existing Reserves', p.5.

535 Ibid.

${ }^{536}$ See page 211 re Lot 277 as an example.
} 
of the Native race as aforesaid as shall be proved to his satisfaction to have been in rebellion and to have subsequently submitted to the Queen's authority, or their descendants; or by warrant under his hand he may set apart out of lands so reserved such portions thereof as he thinks fit, for the use and occupation of such persons. ${ }^{537}$

The blocks listed in 1914 for ex-rebels included 19 Photo 3: George T Wilkinson blocks within Whangamarino. These Lots were numbered 182, 214, 215, 245, 246, 247, 248, 249, $250,251,268,271,278,304,332 \mathrm{~A}, 335,393,442$ and 512. In total, the blocks amounted to 2,141 acres. $^{538}$

\section{The Native Office operations in Whangamarino}

A key figure in the allocation of land to loyal and ex-rebels in Whangamarino was the previously mentioned Government Native Agent and Land Purchase Officer, George Thomas Wilkinson. Wilkinson had been a surveyor during the invasion of Waikato and was at Ōrākau $\mathrm{Pa}$ in $1864 .^{539} \mathrm{He}$

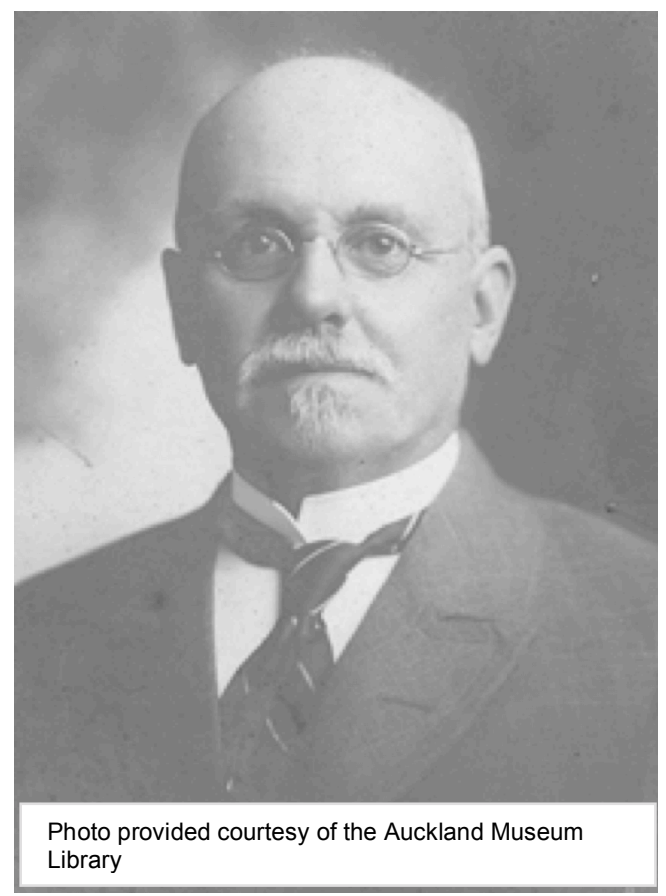
was first hired as an Interpreter in January 1875 and then later as a Native Agent in July that same year. He remained an Interpreter and in 1879 was employed as a Land Purchase Officer. ${ }^{540}$ In 1880 he became a Native Agent for the Native Land Court and in 1902, became the President of the Hikairo-Maniapoto-Tuwharetoa District Māori Land Court before being appointed as the President of the Maniapoto-Tuwharetoa District Māori Land Council and a Native Land Court Judge. ${ }^{541}$

Wilkinson played a major role in Lot 512 as the Native Agent who undertook the preliminary investigation of those rebels who occupied and still lived at Pōkaewhenua in the 1880s. In 1882, Wilkinson had "comprised a list of Lots in various Parishes

\footnotetext{
${ }^{537}$ Section 4 of the Waikato Confiscated Lands Act 1880.

${ }^{538}$ Gilfedder and Haszard 'Existing Reserves', p.10.

${ }^{539}$ Lawn, 'Surveyors', p.22.

${ }^{540}$ George T Wilkinson, 'Papers, 1878-1904', Auckland War Memorial Museum Library, MS 613.

${ }^{541}$ Ibid.
} 
[including Whangamarino] which varied in size from 20 acres to 5,000 acres". ${ }^{542}$ These reserves were gazetted and set aside for natives who were considered "landless" which referred to those Māori, who by virtue of the confiscations in Waikato, were left without land grants or sufficient land for their own subsistence. Those without land grants from the Crown were in the main, considered rebels during the Waikato invasion.

During the 1880s, Māori livelihoods were very different from their Pākehā counterparts. Reports by Wilkinson provide in-depth information on the activites in the Waikato region, including Waikare. In 1884, Wilkinson commented that civil unrest in the Waikato region was virtually non-existent although strong support for the Kingitanga was still evident. ${ }^{543}$ Many Māori had returned to farming or horticulture in particular, with a predominant focus on crops such as potato and maize. ${ }^{544}$

Wilkinson reported that Māori in Waikato were unusual in the virtual absence of drunkenness, with something akin to a ban in the Waikato and King Country territory. ${ }^{545}$ Health issues in the region however included "consumption, asthma, low fever and inflammation of the lungs" resulting in a number of deaths especially amongst children. $^{546}$

Ex-rebels had begun to take up government lands offered under the Waikato Confiscated Lands Act, with a number of rebels already occupying government lands by 1883 including ex-rebels at Pōkaewhenua, where Lot 512 was situated, and Lake Waikare where a reservation was also set aside for ex-rebels at Takapūruharuha pā. ${ }^{547}$

Wilkinson had identified and consulted with those Ngāti Hine that were occupying Pōkaewhenua including taking a census of those already living on the block. Wilkinson recorded 23 males, 20 females and 24 children. ${ }^{548}$ It was also Wilkinson that advised and confirmed to the Assistant Surveyor General in Auckland by telegram of 20 October 1884, that 1,000 acres had been set aside for Ngāti Hine. ${ }^{549}$ In his reply telegram on 22 October that same year, titled "Re Pōkaewhenua for Rebels - Ph

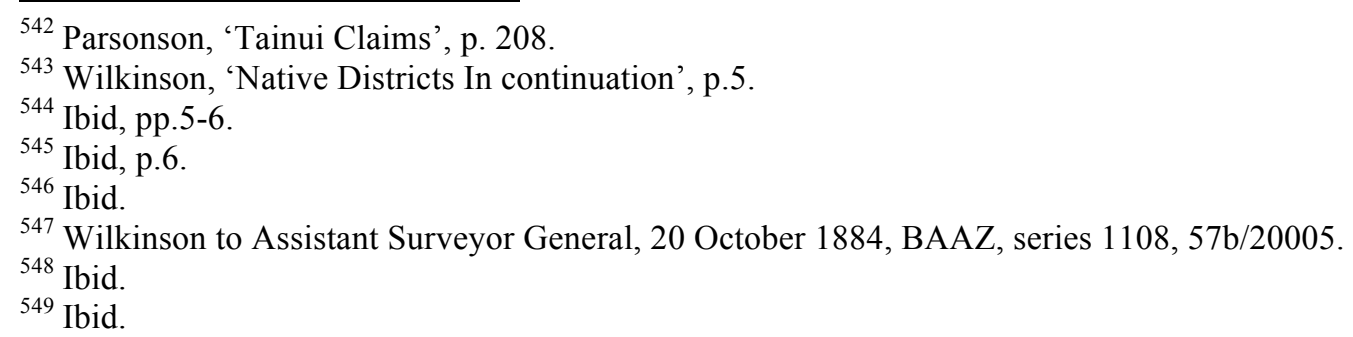


Whangamarino" the Assistant Surveyor conveyed to Wilkinson that the entire area of Pōkaewhenua and Okarea was being surveyed and covered by applications for purchase. The Assistant Surveyor argued that

It will come hard on settlers to have 1000 acres tied up in [Native ownership] and which may never be wanted at all - but I will tell $\mathrm{Mr}$ Stevens ${ }^{550}$ to point out to Natives some cultivatable land of a few hundred acres. $^{551}$

In his onwards telegram to Mr Stevens, the Assistant Surveyor conveys his instructions to meet Ngāti Hine at Pōkaewhenua and point out the boundaries for their occupation and cultivations. The Assistant Surveyor confirmed that Pōkaewhenua was a compensation block for rebels by titling his telegram to Mr Stevens as

Re Pōkaewhenua for returned rebels. Ph Whangamarino $[\mathrm{sic}]^{552}$

Those rebels at Pōkaewhenua were the family of Te Ao Mārama and her children who remained in occupation there until the late 1960s. Te Ao Mārama maintained a domicile on Pōkaewhenua until her death in 1958. Others of her family that lived there included her children, Tamihana Puru, Pakipaki Puru, Paul Puru, Mangu Puru, and the Iwihora and Ngaha whānau, who were also listed as Ngāti Hine. ${ }^{553}$ It is also likely that Te Ao Mārama and others occupying Pōkaewhenua had not needed to sign the declaration required of returned rebels because title for the block was not established until the 1920s when this requirement was no longer needed for a land grant.

It was well known within the hapū of Ngāti Hine that Te Ao Mārama and those at Pōkaewhenua continued to be staunch supporters of the Kīngitanga despite occupying an ex-rebel reservation. ${ }^{554}$ This is unlikely to have been well known by officers such as Wilkinson given the objective of land grants under the Waikato Confiscated Lands Act was to move support away from Tāwhiao. ${ }^{55}$ This does not appear however to be an unusual practice. According to Ngawini Puru, all those Māori living in and around

\footnotetext{
${ }^{550}$ The Local Surveyor at Rangiriri.

${ }^{551}$ Assistant Surveyor to Wilkinson, 'Re Pokaewhenua for Rebels - Ph Whangmarino', 22 October 1884, BAAZ, series 1108, 57b/2005, ANZ, Auckland.

${ }_{552}^{55}$ Ibid.

${ }_{553}^{553}$ Ngawini Puru, Interview, 4 October 2011, Auckland.

${ }_{554}^{55}$ Ngawini Puru, Interview, 4 October 2011, Auckland.

${ }^{555}$ Wilkinson, 'Native Districts Continuation', p.2.
} 
Waikare remained supporters of the Kingitanga and continued to koha annually at the Koroneihana. Inter-whānau connections to Matahuru, Waikare and Rangiriri still ran along familial and Kīngitanga connections. For Ngāti Hine whānau, obtaining land grants through the Native Land Court was a process utilised to remain on and stay connected to hapū land and while following a system of Crown land grants, there was little doubt that those neighbouring papakāinga remained loyal to the Kinngitanga. ${ }^{556}$

The investigation of title in Lot 512 was not the usual process undertaken with other Māori land blocks around the country. In other places, existing customary title was confirmed before land was converted to fee simple title or 'Māori land', but in Waikato, all Māori land in and around Pōkaewhenua had been confiscated so there was no acknowledgement of customary title as the land was considered forfeited. An investigation of Lot 512 began in 1909 when the Court sought to determine who was rightfully entitled to occupy and have title in the block, despite Ngāti Hine having sanctioned occupation by Wilkinson in 1883 .

\section{The Parish of Whangamarino Lot 512}

The investigation of Lot 512 took 17 years and involved 3 Judges and 2 investigative reports, none of which appear to have survived despite extensive archival research. Judge McCormick's decision of 1927 does however, make it clear that after exhaustive hearings take noho and take tūpuna were both identifiable.

Although individual Hauraki Māori had been awarded "out-of-court" settlements in the Compensation Court in 1866 of $£ 260$ for Pōkaewhenua, Pukemore, Akatere, Waerenga, Waikare and the East Waikato Block in general, ${ }^{557}$ when it came to the investigation during the 1920s, none of those claimants or those of Ngāti Whānaunga of Hauraki were included, for no explained or apparent reason.

In 1909, the Under-Secretary for Lands (not the Native Department), advertised in the New Zealand Gazette, that Lot 512 was to be heard at a Native Land Court sitting in Ngāruawāhia on 1 December $1909 .{ }^{558}$ Lot 512 was listed with 11 other blocks in the

\footnotetext{
${ }^{556}$ Ngawini Puru, Interview, 4 October 2011, Auckland.

${ }^{557}$ Waitangi Tribunal, 'The Hauraki Report', p. 220.

${ }^{558}$ A G Holland, 'Applications to the Native Land Court to Ascertain the Names of the Natives to whom allotments in the Parishes of Pepepe, Whangamarino, Taupiri and Koheroa should be granted', New Zealand Gazette, Issue 94, 4 November 1909, p.2942.
} 
Parish as well as two blocks in the Parish of Pepepe, 18 blocks in the Parish of Taupiri and three blocks in the Parish of Koheroa. The purpose of the hearings was to

ascertain whether and on what conditions these lands were reserved for Natives, and the respective shares or interests of each Native therein, and whether the condition under which the reservations, if so made, has been fulfilled. 559

Although many blocks had been occupied since 1883, the lack of clarity had its genesis in promises made by Native Officers to Māori regarding portions of land. Often negotiations and promises made as a result of discussions with Native Officers preceded Court hearings that either worked to expedite the Court processes of alienation or provided added confusion where opposition arose.

Lot 512's hearing in 1909 was to determine who had title to the block, despite Wilkinson having negotiated with and promised the land to those families of Ngāti Hine in 1883.

In 1910, the Block was advertised again as per the 1909 advertisement, along with other blocks in Mangapiko Parish and Ngaroto Parish. ${ }^{560}$ The hearings began in 1912, the hearings had begun, with a number of claimants from Ngāti Hape, Ngāti Te Ata, Ngāti Karere, Ngāti Whānaunga, Ngāti Hine and Ngāti Marae. The Judge concluded hearings with a report that was sent to the Chief Judge in Wellington which was then subsequently lost. Little of the content in that report is known and it is suspected that this report along with others was burnt in the Hope Gibbons fire in 1952 that destroyed Lands and Survey records. An earlier fire in the Parliament Buildings in 1907 is also suspected of destroying early Māori Affairs records. ${ }^{561}$ In any case, no title was awarded to those who had appeared during the investigations of 1909-1912.

During the 1909-1912 hearing, Wilkinson's original promise of 1,000 acres for rebel Māori at Pōkaewhenua was raised. There was a stronger claim by Ngāti Hine and Ngāti Marae to the block despite claims by other hapū that suggested Ngāti Hine had occupied

\footnotetext{
${ }^{559}$ Ibid.

${ }^{560}$ E P Earle, 'Applications to the Native Land Court to Ascertain the Names of the Natives to whom allotments in the Parishes of Whangamarino, Taupiri, Koheroa, Mangapiko and Ngaroto', New Zealand Gazette, Issue 59, 6 June 1910, p.1764.

${ }^{561} \mathrm{See}$ http://www.teara.govt.nz/en/1966/archives/page-3, downloaded on 14 December 2013.
} 
the area by Lake Waikare (Takapūruharuha), rather than further out where Lot 512 is situated. $^{562}$ At the conclusion of the hearings, Judge Holland who had oversight of the investigation provided a report to the Chief Judge but no titles were granted.

Despite the title to Pokaewhenua remaining with the Crown, Te Ao Marama and her whānau continued to live and cultivate there without interruption. By 1927 however, Pokaewhenua along with 24 other blocks in Waikato were identified by the Government as having unresolved ownership. The Native Land Amendment and Native Land Claims Adjustment Act was passed to expedite the awarding of title to those entitled. Pokaewhenua was readvertised for investigation which saw Te Ao Marama and her whānau return to the Māori Land Court.

Unlike previous drawn out investigations, Judge McCormick decided on the block title on 27 August 1927, setting aside a report previously provided by Judge Holland. ${ }^{563}$ In doing so, Judge McCormick also set aside any prior claims determining the right of other hapū and instead submitted the lists of those of Ngāti Hine and Ngāti Marae that were claiming. ${ }^{564}$ The four lists provided by Wiri te Tiere, Tarehurangi te Waari, Porangi Tahakura and Te Ao Mārama were given pre-eminent rights to the Block. ${ }^{565}$ The list submitted by Te Ao Mārama's husband, Puru te Tahua, claiming Ngāti Karere rights were set aside as were the lists by other hapū for failing to demonstrate ahi ka or mana whenua. ${ }^{566}$ Wilkinson, who had had an established relationship with those Māori living on the block before and since 1883, had provided a report some time beforehand that had given both a history of the occupation in that area, as well as arguing definitively that the block was set aside for Ngāti Hine.

By the end of the hearing, Ngāti Hine were found to have the greatest take tūpuna and take noho at Pōkaewhenua, including their having established their economic base there as well as having built a flour mill at Waikiekie. ${ }^{567}$ A full list of the grantees was confirmed by the Court and in 1930 those grantees were apportioned into six separate blocks.

\footnotetext{
562 Judge McCormick, 'Whangamarino 512', Mercer Minute Book, Volume 24, p.270.

${ }^{563}$ McCormick, 'Whangamarino 512', p.270.

${ }^{564}$ Ibid.

565 Ibid.

${ }^{566}$ Ibid.

${ }^{567}$ Tarehurangi Te Waari, 'Whangamarino 512', p.233.
} 


\section{Partition and productivity}

On 13 May 1930, Lot 512 was partitioned by the Native Land Court into six blocks, Lots A-F (see Map 4) with no regard for occupation or consultation with all of its owners. Lot 512 was partitioned "on area with straight boundaries and not in accordance with occupation as was often the case". 568

\section{Map 4: Pōkaewhenua - Lot 512, Parish of Whangamarino}

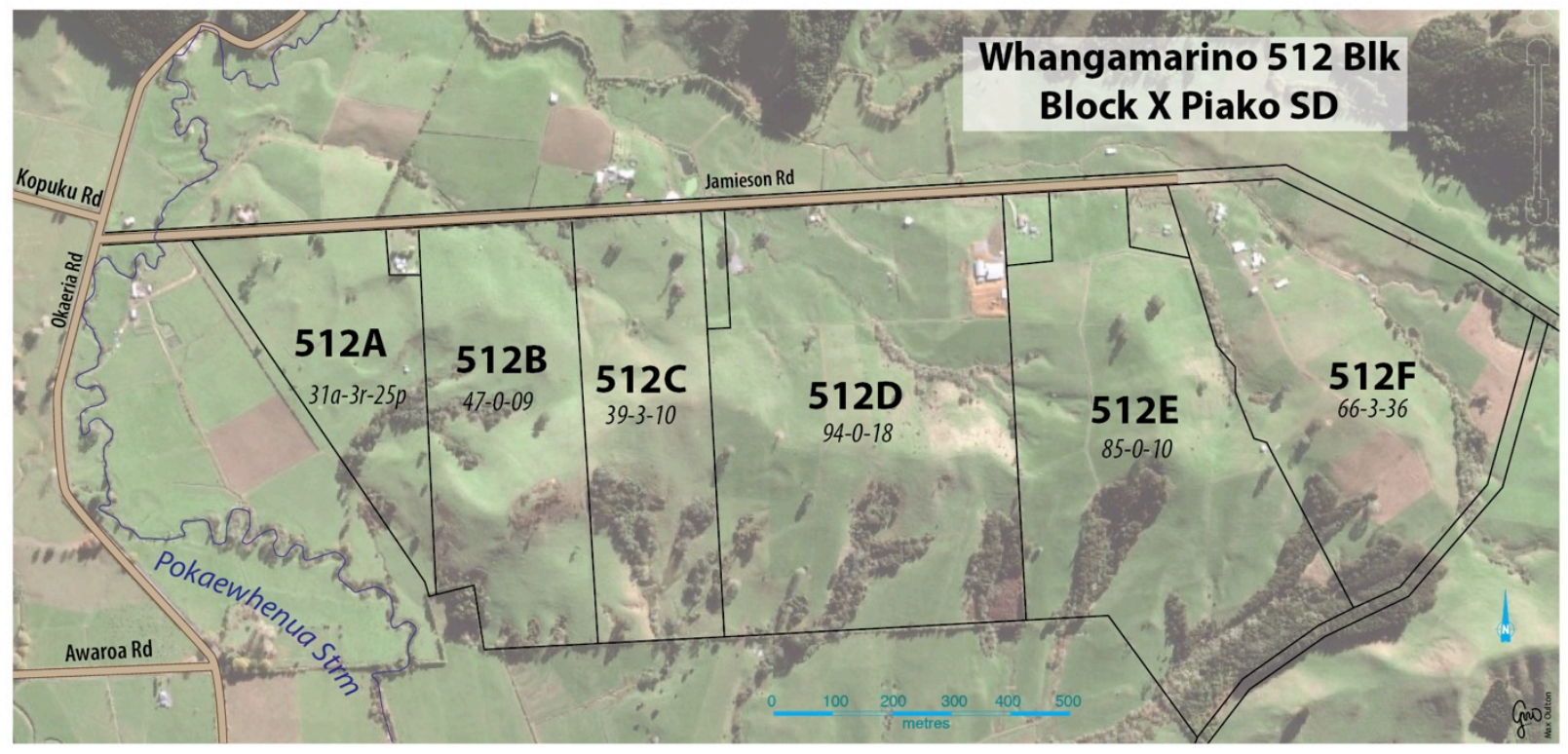

The original grantees were divided into each partitioned area based on the lists provided by the four named above as having pre-eminent rights: Tarehurangi Te Waari, Wiri te Tiere, Porangi Tahakura and Te Ao Mārama as well as an additional list provided by Toka Pouaka, with the remaining Ngāti Hine members, not yet allocated, put into Lot 512F. Lot 512 was partitioned as follows:

\section{Lot 512A (Porangi Tahakura's list)}

\begin{tabular}{|l|l|l|l|}
\hline Albert Tipene & Te Here Tahakura & Hori Tahakura & $\begin{array}{l}\text { Hori } \\
\text { Tahakura }\end{array}$ \\
\hline Kura Tipene & Manukau Tipene & Mary Tipene & Mataihaea Tahakura \\
\hline Parekawhia Tipene & Rangi Henare Rowe & Tahakura Hori & Tania te Waari \\
\hline Tamati Porangi & Tuhira Tahakura & $\begin{array}{l}\text { Tuhira Wharekawa } \\
\text { Tahakura }\end{array}$ & Te Uru Tahakura \\
\hline Waari Werahiko & Wheti te Waari & William Haora Hull & \\
\hline
\end{tabular}

\footnotetext{
${ }^{568}$ M.A. Brook, 'Parish of Whangmarino Lot 512', Waikato Minute Book, Volume 74, 12 October 1963, p.260.
} 


\section{Lot 512B (Toka Pouaka's list ${ }^{569}$ )}

\begin{tabular}{|l|l|l|l|}
\hline Henare Kahi & Te Haranui Tauwhare & Heeni Tahana & Hona Tahana \\
\hline Kahutoroa Pouaka & Matire Rangikataka & Matekino Te Whaiti & Maraina Tahana \\
\hline Ngarama Pouaka & Ponui Kahi & Pokohuia Kahi & Parerona Tauwhare \\
\hline Paru Waraki & Poihaere Tahana & Ruruhi Kahi & Rangi Rerewa Purua \\
\hline Te Rawhakaari Te Whaiti & Ranui te Whaiti & Taehuri Hona & Toka Pouaka \\
\hline Tamihana Kahi & Tira Kahi & Te Waiata Tupuhi & Te Whaiti te Pihinga \\
\hline $\begin{array}{l}\text { Te Whakamatamatau } \\
\text { Kahi }\end{array}$ & Wahawaha Tauwhare & & \\
\hline
\end{tabular}

\section{Lot 512C (Tarehurangi te Waari's list)}

\begin{tabular}{|l|l|l|l|}
\hline Te Awhimate Pehiarae & Hauauru Pataua & Kaumoana Pehiarae & Kahumakiri Pataua \\
\hline Kowharawhara Pataua & Kotuku Pataua & Te Kirikiri Rihitoto & $\begin{array}{l}\text { Ngātimahuta } \\
\text { Takaroa Taneti }\end{array}$ \\
\hline Pataua Tarehurangi & Parepounamu Pataua & Rihitoto Werahiko & $\begin{array}{l}\text { Rangimanako } \\
\text { Pataua }\end{array}$ \\
\hline Rangi Rihitoto & Tarehurangi te Waari & Tio Rihitoto & Te Turi Kaumoana \\
\hline Tukapea Pataua & Tini Huia Rihitoto & Tupu te Momo & Wiremu Ngawhare \\
\hline Te Waitere Pataua & Te Waari Werahiko & & \\
\hline
\end{tabular}

\section{Lot 512D (Te Ao Mārama's list)}

\begin{tabular}{|l|l|l|l|}
\hline Ahinui Heeni & Te Ahuahu Taharoa & Te Ao Mārama te Puru & Arama Heeni \\
\hline Te Ata Tukirunga & Hemi Taikaranga & Hemotitaha Taikaranga & Hera Purua \\
\hline Hoani Maki & Te Hore Taikaranga & Hori Maki & Kahi te Puru \\
\hline Kahupoporo Tukirangi & Te Kere Waikato & Kiripakapaka te Puru & Kopa te Puru \\
\hline Te Maemae Ahuahu & Te Mangu te Puru & Mata Hemi & Mata Tukirunga \\
\hline Moki te Puru & Nepe Waikato & Nopera Hemi & Paeahi te Manu \\
\hline Paewa Kiripakapaka & Pakipaki te Puru & Pouaka Ahuahu & Puke Maki \\
\hline Rangimarie Ahuahu & Rangitamoana Rawiri & Te Rai te Puru & Rawinia te Puru \\
\hline Rawiri te Manu & Repe Maki & Rihirihi Waikato & Ruhiruhi Hemi \\
\hline Tai te Ahuahu & Tame Tukirunga & Tamehana te Puru & Tangiaru Heeni \\
\hline Tiri Hemi & Tuhewa Hemi & Tukirunga Ahuahu & Turipo Maki \\
\hline Turoa te Ahuahu & Te Werawera Papa & Te Werawera Taikaranga & \\
\hline
\end{tabular}

\section{Lot 512E (Wiri te Tiere's list)}

\begin{tabular}{|l|l|l|l|}
\hline Amo Tupuhi & Aue Teri & Eruera Teri & Hone Tuki Tupuhi \\
\hline $\begin{array}{l}\text { Hoani Papita Tuke } \\
\text { Tupuhi }\end{array}$ & Hemo Wilson & Hae Noho & Te Keu Whakamau \\
\hline Te Kuiatu Tuki Tupuhi & Te Koro Wilson & Kapo Purua & Kere Purua \\
\hline Kerei Purua & Māori te Iki & Matetu Purua & Ngamako Teri \\
\hline Noki te Iki & Ngohi Purua & Ngakiri Toto & Nekeneke Noho \\
\hline Pakira Wilson & Parehauraki te Iki & Pakira Toto & Potae Noho \\
\hline Rahui Tupuhi & Te Riko Toto & Rongo Wareki & Te Ruaki Toto \\
\hline Rotana Noho & Simon Teni & Tuki Tupuhi & $\begin{array}{l}\text { Tuaiwa } \\
\text { Tupuhi }\end{array}$ \\
\hline Taea Teri & Teri Simon & Tame Teri & Tiini Purua \\
\hline Toto Taikaranga & Tomopo Toto & Teni Noho & Tamati Noho \\
\hline
\end{tabular}

${ }^{569}$ Toka Pouaka also provided a list to the Māori Land Court and on partition, his list was allocated to this block. 


\begin{tabular}{|l|l|l|l|}
\hline Urumakawe Amo & $\begin{array}{l}\text { Whakahawea Tuke } \\
\text { Tupuhi }\end{array}$ & Wetere Simon Tere & Te Whakahau te Iki \\
\hline Te Waina Purua & Wehe Purua & Te Whero Noho & \\
\hline
\end{tabular}

\section{Lot 512F (others identified as Ngāti Hine)}

\begin{tabular}{|l|l|l|l|}
\hline Awhi Tauroa & Ani te Pihinga & Hori Tauroa te Tere & $\begin{array}{l}\text { Hawi Tauroa te } \\
\text { Tere }\end{array}$ \\
\hline Hare te Toko & Hamana Tauroa & Haki Tauroa & Hori te Pihinga \\
\hline Hone te Pihinga & Haki Namu & Huihui Namu & Kiri Rawiri \\
\hline Kohikohi Ani & Merehira te Tere & Mererei te Pihinga & Matena Hori \\
\hline Mereaina Hori & Merehira te Namu & Namu te Pihinga & Ngaroimata Ani \\
\hline Pera Tauroa & Te Pihinga te Tere & Pera te Pihinga & Te Pupuhi Hori \\
\hline Pareato Tauroa & Riki Tauroa te Tere & Rihi te Pihinga & Rangi Hori \\
\hline Rina Pera & Riki Hori & Tuhituhi te Pihinga & Tautahi Hori \\
\hline Tani Hori & Tuhituhi Pera & Topi Namu & Taiuru Rawiri \\
\hline Wiri Pera & & & \\
\hline
\end{tabular}

It became apparent that the owners were either not fully aware that the partition had taken place, who was apportioned to each parcel or what effect this had on existing whare, cultivations and the burial of pito whenua. Although the paper partition was confirmed in the Māori Land Court, the actual boundaries were not surveyed and its physical boundaries paid little attention to owner occupation or papakāinga. This became a source of contention in 1993 for owners in Lot 512D who were seeking land in Lot 512C where Te Ao Mārama's whare was located. In her testimony to the Court in 1993, Miss King ${ }^{570}$ states that the partition orders of 1930 "were fixed as a result of area definitions and defined by straight lines [with] no relevance to occupation". 571 The sitting Judge, Carter, confirmed that this was the practice while going so far as to say that occupation was not often taken into consideration when determining partition boundaries. ${ }^{572}$ Evidence by Elsie Davis (by map) and Baker Puru (through occupation and kōrero) confirmed that Te Ao Mārama's whare was within the Lot 512C boundaries. Judge Carter's memorandum to Mr Archibald (the lawyer representing owners in Lot 512D) is clear in the Court's position by stating that

It must be pointed out that the boundaries were fixed, not by physical characteristics, but by north south lines to enclose prescribed areas and until

\footnotetext{
${ }^{570}$ A descendant of an original owner in support of the application by 512D owners.

${ }^{571}$ Miss King - Lawyer in support of owners in Lot 512D, 'Parish of Whangamarino Lot 512', Waikato Minute Book Volume 74, 1993, p.260.

${ }^{572}$ G.D Carter, 'Parish of Whangamarino Lot 512', Waikato Minute Book Volume 74, 12 October 1993, p.260.
} 
those areas and boundaries had been fixed by survey nobody could have been sure of any correct boundaries. ${ }^{573}$

If the Court was unsure, then the block's owners were more so. It is a component of the argument of this thesis and the occupation of Lot 512 that little regard was given by the owners to arbitrary boundary lines provided by the Court. As an example, owners in Lot 512D, had established their papakāinga, cultivations and pito whenua in an area that encompassed Lots 512B, C and D. Map 5 shows the location of whare across the block previously occupied by Te Ao Mārama and her children. The whare in the area within Lot 512A was occupied by the Tipene whānau. In 1993, owners in Lot 512D sought to have the boundaries moved to include their papakāinga and those areas where pito whenua had been buried, ${ }^{574}$ however the Court saw the partition differently.

However during the original partition, the Māori Land Court partitioned Lot 512, it argued that the representative owners were present and agreeable to a partition, ${ }^{575}$ however there is no indication that a map was present, a list of names of those in attendance other than Tamehana Puru (a child of Te Ao Mārama), or that wider consultation was conducted on where the boundaries were to be positioned to confirm existing occupation. Rather, a dispute arose regarding the share distribution to $\mathrm{Te}$ Ahuahu Taharoa to compensate for his exclusion from Lot 393 (Takapūruharuha pā). This dispute appears to have become the focus of the Court hearing which required an adjournment till later in the afternoon so that owners could come to a resolution. ${ }^{576}$

When the hearing resumed at $2 \mathrm{pm}$, it is not clear from the Court minutes, that any owners were present, nor is there an indication where the boundaries for the partition were to be drawn, other than by block sizes. ${ }^{577}$ Instead, the owners of all 6 blocks were instructed that there was

\footnotetext{
${ }^{573}$ Memorandum from Judge Carter to Mr Archibald, 'Re: Parish of Whangamarino 512 Block - Section 34(9B)/53', 9 June 1993, p.1.

${ }^{574}$ Judith-Anne Wanakore in Māori Land Court, 'Whangamarino 512D2', Waikato Minute Book, Volume 78, 30 October 1995 p.186.

${ }^{575}$ G.D Carter, 'Parish of Whangamarino Lot 512', Waikato Minute Book, Volume 78, 10 November 1995, p.223.

${ }^{576}$ Ibid, p.219.

${ }^{577}$ For example 512A: 31-3-25, 512B: 47-0-9, 512C: 39-3-13, 512D: 94-0-18, 512E: 85-0-10, and 512F: 66-3-36.
} 
three months allowed for all parties to remove any houses or fences belonging to them respectively and not included in their parcels in this partition. $^{578}$

\section{Map 5: Pōkaewhenua - Lot 512 with whare locations}

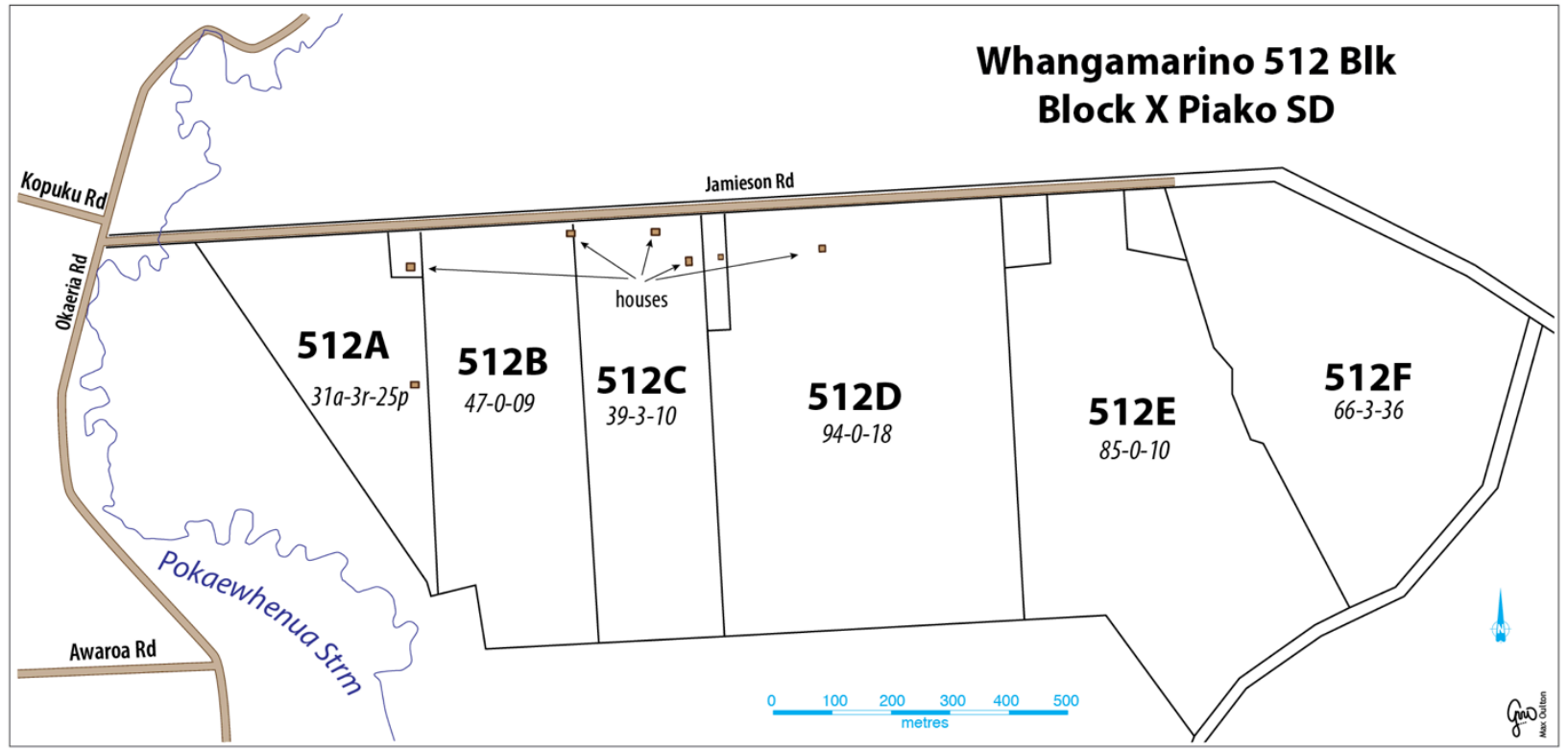

Aerial maps of Lot 512 submitted to the Māori Land Court in 1993 show that whare in 1929 had not moved by 1948, suggesting that either the Orders were ignored or the owners had a belief that the boundaries lay differently on the block and within their own existing fence lines as per their occupation.

In 1948, Kahi Puru (another child of Te Ao Mārama) applied to have two acres subdivided within Lot 512D for a papakāinga and marae for Ngāti Hine under King Koroki. This subdivision was also to encompass the area where Te Ao Mārama was living. The two acres were subdivided with the Partition Order identifying the area as being cut off from "the north-western corner of [the] block". 579

A map of the area was not submitted or referred to at this. In 1962, the first survey plan of Lot 512 to be drawn up was submitted to accompany an alienation application for Lots $512 \mathrm{E}$ and F. This survey however, only set out "precisely the areas that were stated in the [1930] order, with the remainder of the block remaining unsurveyed". 580

\footnotetext{
${ }^{578}$ Carter, 'Lot 512', p.220.

579 Ibid.

${ }^{580}$ Ibid, p.221.
} 
The actual survey of Lots 512D1 and D2 finally took place in 1989, showing for the first time, where the boundary lines were located including the area that was set aside for the marae. Up until 1989, the marae intended for Lot 512D1 had not been built due to a lack of funds within the whānau to build a complex large enough to cater for Te Ao Mārama's descendants. The marae at Taniwha (Tangoao), utilised by the whānau was already incapable of housing those descendants. Following the identification of its actual location from Māori Land Court records, it became clear to the owners that it was not in the area the owners had believed it to be and the lay of the land was not suitable for the marae. Judith-Anne Wanakore (a great granddaughter of Te Ao Mārama) provided evidence to the Court stating that

The area that has been allocated as Marae, that is Whangamarino 512D1, is on the side of the hill and is just not suitable [sic]. ${ }^{581}$

The objective of partitioning out Lot 512D1 for a marae was, Wanakore argued, to position the boundaries so that Te Ao Mārama's house would be within the two acre area that would also include whānau whenua that were buried there. ${ }^{582}$ The Court confirmed that it was the owners' belief that the partitions of 1930, 1948 and 1989 should have followed the fence lines that had been erected by the owners, showing their occupation areas, and that survey boundaries should have aligned. ${ }^{583}$ However, the Court advised the owners that

The original partitions were based solely on areas and it seemed to have been that the Court anticipated that people would have to move from their dwellings when it made the Order. ${ }^{584}$

The Court was clear that it had never been its intent or practice to have the partition on existing fence lines, and that if it was, it would have done so in its original order. As

\footnotetext{
${ }^{581}$ Wanakore, 'Whangamarino 512D2', p.186.

582 Ibid.

${ }^{583}$ Judge Carter in Māori Land Court, 'Whangamarino 512D2', Waikato Minute Book, Volume 78, 30 October 1995 p.187.

584 Ibid.
} 
stated by Judge Carter previously, the court's practice was to apply straight lines based on area, not occupation. Judge Carter also argued that

The Court advised those present [one owner] that the original partitions were based solely on areas and it seemed to have been that the Court anticipated that people would have to move from their dwellings when it made the Order. ${ }^{585}$

This is an incongruous statement. The burying of pito whenua was an established custom of Ngāti Hine that marked not only occupation but also sites of significance. Te Ao Mārama did not bury pito whenua on land that she would be moved from. In burying pito whenua in Lot $512 \mathrm{C}$, she had claimed take whenua and expected that those sites remained in the whānau. ${ }^{586}$

The significance of the Lot 512D1 partition should not be underestimated. The owners sought to secure an area for a marae within their perceived boundaries and on the site where Te Ao Mārama lived and whānau whenua buried. Elsie Puru-Davis (granddaughter of Te Ao Mārama) in her effort to secure this area, also wrote to the New Zealand Historic Places Trust seeking assistance given its importance to the whānau. ${ }^{587}$

By 1995, Judge Carter would admit no error on the Court's part in the 1930 and 1948 partition and by virtue of that decision, the 1962 survey of Lot 512E and F and the 1989 survey of Lots 512D1 and D2 were also, according to the Court, without error. For all intents and purposes the Court's process was without fault. However from a whānau perspective an error remained. The lack of representation by owners in 1930 when the partition was drawn up, the lack of maps or plans to confirm boundary lines and the continued misrepresentation of boundaries persisted into the 1990s.

Although the owners believed their areas of occupation had been secured as per their continued perceptions of the boundaries, through pito whenua, fence lines, occupation

\footnotetext{
${ }^{585}$ G.D Carter, 'Whangamarino 512D1 - Section 338/93', Waikato Minute Book, Vol 78, 30 October 1995, p.186.

${ }^{586}$ Ngawini Puru, Interview, 4 October 2011, Auckland.

${ }^{587}$ Elsie Puru-Davis, Letter to New Zealand Historic Places Trust, 29 September 1992.
} 
and cultivations, the actual boundaries drawn did not reflect this. This error from the whānau's perspective was perpetuated in 1948 and again in 1989. The site of Te Ao Mārama's whare was identified as a place of importance for the whānau, but without a plan, the Māori Land Court drew boundaries that were at odds with the owners' interests.

In 1989, it became evident that the boundaries had shifted and when in 1993 the owners sought redress in the Māori Land Court to shift the boundaries to effect their interests, the Court was able to offer sympathy but not resolution. This example shows the inflexibility of the Court and its disregard of owners' interests in determining the utilisation and occupation of their land. The omission of properly drawn maps, owner attendance and a continued practice of utilising surveying methods that benefitted nonowners, created an error that was perpetuated through to the 1990 s.

By this time, the owners had successfully removed the Māori Trustee as agent on the land block and leased Lots 512D1 and D2 to a local farmer so as to ensure it was in productive utilisation as stipulated by the Māori Land Court during the 1960s. The remainder of Lot 512 was also leased to neighbouring farmers. In the 1950s however, while Te Ao Mārama and her whānau were occupying the block and utilising the land for small market gardens and subsistence purposes, the ability for farmers to alienate Māori land by lease or sale could be processed through an application to the Māori Land Court.

\section{Application for alienation}

In July 1960, an application was submitted to the Court to consider the lease of Lots $512 \mathrm{E}$ and $512 \mathrm{~F}$. The application was to summon a meeting of owners to consider the following:

That the land be leased to Reginald John Ellmers of Te Kauwhata, farmer for a term of 21 years from 1.9 .60 at a yearly rental of $£ 75$ with Right of 
Renewal for a further 21 years at a rental to be fixed by the Court at the expiry of the first term. ${ }^{588}$

Under this application, Ellmers would be entitled to compensation for improvements made by him at the conclusion of the lease, or alternatively the land could be sold for $£ 1,500$ or the current valuation at the time of sale. To progress Ellmers' application, the Court utilised the instruments provided in the Māori Affairs Act 1953.

\section{Māori Affairs Act 1953}

The purpose of the Māori Affairs Act 1953, according to its Preamble, was to consolidate and amend previous Māori land legislation and to consolidate provisions of legislation relating to Māori themselves. ${ }^{589}$ This included General land owned by Māori as well as Māori land.

There were key parts of the 1953 Act that had an impact on Lot 512. Part IV allowed for orders whereby a receiver could be appointed to enforce charging orders against Māori land. Part XIX contained general provisions for land to be alienated by its Māori land owners, Part XX allowed for leases of Māori land. Part XXI outlined how the Board of Māori Affairs could acquire Māori land for the Crown, including undivided shares in land. Part XXIII set out the provisions under which meetings of owners could be held, resolutions passed and the the Māori Trustee made agent to progress alienation. Part XXIV sought to have Māori freehold land occupied and farmed by Māori and Part XXV provided for Māori or General land owned by Māori that was considered unproductive, to be disposed of by the Māori Trustee in the national interest. ${ }^{590}$

With regard to Part XXIII and Part XXV, an application by "the local authority of the district or by any person interested" could be made for an order in respect of developing

\footnotetext{
${ }^{588}$ Brook, M.A (1960), 'Parish of Whangmarino Lot 512F: Application for meeting to consider lease or sale to R.J. Ellmers', Auckland Thames Alienations Minute Book, Vol 1, 20 October 1960, p.249 ${ }^{589}$ Māori Affairs Act 1953.

${ }^{590}$ Other sections that had an impact on Māori land in general were Parts XII and XIII which provided for the conversion of uneconomic Māori land interests to be vested in the Māori Trustee and Part XVIII which allowed for Consolidation schemes the purpose of which was so that "as far as may be necessary to effect such consolidation, the redistribution of the interests of the several Māori owners in the Māori freehold lands to which the scheme primarily relates so that, as the result of the scheme, the lands will be held by the several owners in suitable and convenient areas that may be profitably used to their advantage and in the public interest" - see Section 194 of the Act.
} 
or bringing into production a nominated land block. ${ }^{591}$ However, having applied under Part XXIII to summons a meeting of owners, Ellmers utilised provisions in Part XXV to bring Lots $512 \mathrm{E}$ and $\mathrm{F}$ into production. The Court then ordered a current valuation and District Officer's report on the status of the block.

The report by the District Field Supervisor determined that the parent block would make "one good sheep farm or subdivide into three dairy farms". 592 The Field Supervisor estimated that the cost to develop the parent block ranged from $£ 21-23,000$ for a sheep farm or $£ 11-12,000$ for a dairy farm. The Supervisor made two important recommendations that led him to conclude that he had no objection in supporting the alienation of Lots 512E and F to Mr Ellmers. The first recommendation considered that the "costs of development and settlement [were] too high...for the average Māori" and secondly that he doubted whether loans of over $£ 16,000$ to individual Māori farmers would be approved by the Board of Māori Affairs. ${ }^{593}$

According to the Supervisor, there was no prospect of Māori receiving loans to develop this area given the costs to undertake sheep farming was $£ 21-23,000 .^{594}$ In the Supervisor's opinion, he knew of no Māori farmer who had sufficient cash assets to put into farming and therefore, saw Ellmers as an arguably better option in so far as sheep farming was concerned. ${ }^{595}$

There are however, some anomalies in the report furnished by the Supervisor and the justification for excluding Māori. The costs to solely develop a sheep or dairy farm were based on the development of the entire Lot 512 block, not Lots 512E and F exclusively. Also, the premise that the costs fell outside the "average Māori" and Māori were therefore ineligible for loans, applied only to the cost of a sheep farm. There appeared to be no consideration of Māori developing a dairy farm at a cost of £1112,000 , which fell well within the $£ 16,000$ lending threshold under Māori Affairs. ${ }^{596}$

\footnotetext{
${ }^{591}$ Section 387, Māori Affairs Act 1953.

${ }^{592}$ CA Roberts to the The Registrar, 'Parish of Whangamarino 512E \& F: Sale to Ellmers', 18 August 1961, Māori Land Court (BACS), series 4958, $1591 \mathrm{~g}$.

593 Ibid.

594 Ibid.

595 Ibid.

${ }^{596}$ Ibid.
} 
In its natural state, parts of the block were covered in ti kōuka (cabbage trees) and aruhe (fern root) and consideration was given to Ellmers on his capacity to develop the land and bring it into production. Consideration was inevitably also given to his ability to access funds, which were available through the Marginal Lands Fund.

The Marginal Lands Act 1950 allowed for the Marginal Lands Fund. As mentioned in Chapter Four, the Marginal Lands Fund was designed to provide loans for clearing, cultivation, grassing, fencing, drainage, irrigation, buildings, farm machinery, livestock, or any purpose "having for its object, the successful development and farming of a property regarded as suitable for a loan". 597

The assistance provided to farmers was wide and inclusive (see Chapter Four for the full list of allowable activities). Although not explicitly set out in the Marginal Lands Act, Māori land was not eligible for assistance. Instead, the Māori Purposes Act was passed in 1950 to develop unproductive Māori land or General land owned by Māori. Section 33 of the Māori Purposes Act reads:

(1) The provisions of this Part of the Act shall apply to any Māori freehold land, or any land owned by Māoris [sic], which is not subject to any subsisting valid lease or a valid contract to grant or renew a lease. ${ }^{598}$

\section{The Māori Purposes Act}

The Māori Purposes Act sought to ensure that where land was left unproductive, provisions were available for that land to be alienated, while any improvements made by leasees were fairly compensated. ${ }^{599}$ There were no comparative provisions to assist Māori with the development and support to productively use their lands to the extent allowed for under the Marginal Lands Act, or at least none legislated as extensively as provided. There existed instead an avenue to alienate economically unproductive or marginal Māori land that could better be used by non-Māori.

Under the Section 2 of the Marginal Land Act, marginal land is interpreted as

\footnotetext{
${ }^{597}$ Department of Statistics, The New Zealand Official Yearbook, Wellington, Department of Statistics, 1963 , p.299.

${ }^{598}$ Section 33(1) of the Māori Purposes Act 1950.

${ }^{599}$ See Chapter Five.
} 
any land that in the opinion of the Board is used, or is capable of being used, for agricultural or pastoral production, but which, in the opinion of the Board, is not developed to its full productive capacity or is declining or tending or likely to decline in productivity or has suffered or is liable to suffer damage or loss of productivity from floods, or similar disasters, and which, in the opinion of the Board, is worth developing, maintaining or protecting.

Under the Māori Purposes Act, unproductive land was considered any that was not farmed appropriately and could arguably be within the definition of "marginal land". The key difference is that marginal land attracted funding and support by the Department of Lands and Survey while unproductive Māori land attracted criticism and concern, with little support and funding in the Waikato by the Department of Māori Affairs. It was more likely that land in the Waikato encouraged alienation than development particularly for those seeking to settle in the region, which was supported under the Land Settlement Promotion Act 1952.

\section{Land Settlement Promotion Act 1952}

The Land Settlement Promotion Act 1952 was enacted to assist farmers and was passed with the primary objective of allowing the Minister of Lands "to take, in certain circumstances any farm land that is suitable for settlement, and is, or when subdivided and developed will be, capable of substantially increased production". ${ }^{600}$ The Act protected some farmers by noting that "land cannot be taken from any person owning less than the equivalent of two economic farms, and provision is also made for the retention of land for the owner's children" ${ }^{601}$ These same protections were not afforded to Māori under the Māori Purposes Act of 1950, or previous legislation regarding Māori land from 1909.

The key driver for the Land Settlement Act was to ensure the maintenance of New Zealand's exports of meat and dairy products to Britain and for the improvement of

\footnotetext{
${ }^{600}$ Department of Statistics, Official Yearbook, p.299.

${ }^{601}$ Ibid.
} 
unproductive land. ${ }^{602} \mathrm{~A}$ great deal of parliamentary discussion prior to its enactment focused on the need for all possible areas of land to be turned to greater production. As mentioned previously, drivers such as assisting with Food for Britain, returned servicemen and maintaining New Zealand's economic advantage provided the impetus to maintain a keen focus on farming and specifically scientific farming utilising modern equipment, fertilisers or farmed as an economic unit by a single farmer.

Before access to Māori land could be progressed, the Māori Land Court was required to obtain a current valuation so that a fair price was offered to the Māori land owners.

\section{The valuation of Lots $512 \mathrm{E} \& \mathrm{~F}$}

The valuation of Māori land was a process implemented to ensure that lease or sale prices for Māori land were equitable and allowed for an assessment of the state of the land block. Māori land in the Waikato was often considered by the Māori Land Court to be unimproved or unproductive, unless previously farmed and where possible some consideration in the valuation to reflect this was included.

The assessment of costs to bring the land into production through clearing, draining, preparing, grassing and the like was ordinarily done by the District Field Officer in consultation with the Government valuer. In concert with surveyors, a valuation was prepared, supposedly for consideration by the Māori owners. More often than not however, the valuation was determined by the Māori Land Court and Māori land undervalued in comparison to neighbouring General land. As seen in Chapter Four, Māori land alienated under Part XXV in 1964 was valued at $£ 7$ per acre as opposed to European land which attracted $£ 40$ per acre.

In the case of Lots $512 \mathrm{E} \& \mathrm{~F}$, the lease price originally offered by Ellmers was $£ 75$ per annum for both blocks or $£ 0.88$ per acre per annum for Lot $512 \mathrm{E}$ and $£ 1.14$ for Lot $512 \mathrm{~F}$ (or $£ 1.01$ on average). The lease period was to be for a period of 21 years with a further right of renewal of another 21 years. As an economic unit, both Lots $512 \mathrm{E} \& \mathrm{~F}$

\footnotetext{
${ }^{602}$ See Ernest Corbett, 'Land Settlement Promotion Bill' in NZPD, Volume 298, 4 September 1952, pp.1270-1291, 1294-1327 and 1482-1488.
} 
were considered uneconomical separately and the sitting Judge, Judge Brook, considered that both blocks should either be sold together or leased together. ${ }^{603}$

Following a valuation of $£ 1,680$ and $£ 1,500$ for Lot 512E and $F$ respectively, the lease price to be charged was set at $£ 110$ per annum ( $£ 1.29$ per acre) and $£ 100$ per annum, (£1.51 per acre) for Lot $512 \mathrm{~F} .{ }^{604}$ This price exceeded Ellmers’ offer by $£ 0.41$ per acre for Lot $512 \mathrm{E}$ and $£ 0.37$ per acre for Lot $512 \mathrm{~F}$ putting at risk the proposal to have both blocks leased and brought into production. On 22 March 1961, to ensure production on the blocks, Judge Brook made a ruling to change the resolution from lease to sale.

\section{Change of resolution from lease to sell}

Judge Brook's ruling to change the resolution from lease to sale was made after the notices to the owners had been sent advising them of a lease only. The new resolution was to be read out at the owners' meeting as an alternative to the resolution to lease because Ellmers' original offer did not meet the required annual lease payments as per the valuation. ${ }^{605}$

Judge Brook used his discretion to change the resolution from lease to sell to assist Ellmers, not as a means of improving the owners' interest. By doing so, Brook ensured the block was both utilised by Ellmers and brought into production as directed by the Board of Māori Affairs.

The notice to be read out at the meeting was to advise the owners that there were two resolutions to be voted on: a resolution to either sell to Ellmers; or a lease to Ellmers for 30 years backdated to 1 April 1961. The 30 year lease resolution exceeded the original 21 years proposed by Ellmers and there is no evidence for Judge Brook's rationale, other than it excessively alienated the owners from their land. In addition, the owners were obligated to pay $33.3 \%$ of all improvements made to the land at the end of the 30 year lease, leaving the owners with the option of alienation during their lifetime by lease, or an outright sale.

\footnotetext{
${ }^{603}$ M.A Brook, 'Parish of Whangamarino Lot 512E, Parish of Whangamarino Lot 512F: Applications for meetings to consider lease to Ellmers', Auckland-Thames Alienations Minute Book, Volume 1, 22 March 1961, p.272.

${ }^{604}$ M.A Brook, 'P/Whangmarino 512F, P/Whangmarino 512E: Application for meeting to consider lease to Ellmers', Auckland-Thames Alienation Minute Book, 27 January 1961, pp.268-269.

${ }^{605}$ Ibid.
} 
Furthermore, there was no mention in the notice that if the resolution to sell was rejected, the block would be passed over to the Māori Trustee who could negotiate either a sale or a lease on their behalf, regardless of the owners' wishes or interests.

It is unlikely that owners were aware that the Judge could pass their land over to the Māori Trustee under Section 308(2) of the Māori Affairs Act 1953, for the purposes of a Section 387 alienation. Section 308(2) stated that

Where a resolution in accordance with paragraph (b) or paragraph (c) of subsection one of section three hundred and fifteen hereof is rejected by the meeting, a resolution in accordance with paragraph (e) thereof may be submitted to the meeting notwithstanding that notice thereof may not have been given in accordance with this section.

Section 315 refers to resolutions that may be passed at assembled owners' meetings. Subsection (b) and (c) stipulate the following:

(b) That a proposed alienation of the land or any part thereof to the Crown be agreed to:

(c) That a proposed alienation of the land or any part thereof to any person other than the Crown be agreed to.

With the rejection of (b) and (c), subsection (e) allowed for the Māori Trustee to be authorised

to act as the agent of the owners to negotiate for and carry into effect the alienation, by sale or lease or otherwise as may be specified in the resolution.

It was Section 315(1)(e) that allowed the Māori Trustee to act on behalf of the owners "for any specified purpose".

None of these stipulations were conveyed to the owners prior or during the owners' meeting. However, to progress the application, Judge Brook was faced with another 
restriction on Lot 512 under the Waikato Confiscated Lands Act 1880 that had remained in place to protect owners' interests and to ensure the inalienability of returned land to rebels.

\section{Discharging restrictions to alienation}

Restrictions on the alienation of land by Māori were implemented to ensure Māori were not made landless by virtue of the alienation of their land or land blocks. One of the requirements of the District Māori Land Boards was, among other things, to "ensure 'that no Native will be by reason of the alienation become landless". ${ }^{606}$ This provision was also contained in the Waikato Confiscated Lands Act 1880 as mentioned previously, as well as the Native Land Amendment and Native Land Claims Adjustment Act 1927.

The original title order to Lot 512 and each of its partitioned blocks had the following restriction:

Land inalienable except by will (Subsection 12 of section 39 of the Native Land Amendment and Native Land Claims Adjustment Act 1927) until the Court shall remove or vary such restriction.

This same clause however, made it possible for a Judge, in contrast to the protection provided under Section 39(12) of the Native Land Amendment and Native Land Claims Adjustment Act to also "from time to time remove or vary any such prohibition or restriction". ${ }^{607}$

Also, the restrictions on inalienability did not stop the Native Land Court, or the District Māori Land Boards from acting against its direction given there remained a counter Section to the rule within their guiding legislation, specifically Section 425 of the Native Land Act 1909 which reads:

\footnotetext{
${ }^{606}$ John Hutton, 'The Operation of the Waikato-Māori District Māori Land Board', Report written for the Crown Forestry Rental Trust, 3 May 1996, p.23.

${ }^{607}$ Section 39(12) Native Land Amendment and Native Land Claims Adjustment Act 1927.
} 
(1) The Governor may by Order in Council, in any cases in which he thinks it expedient so to do, consent to the confirmation of any alienation, or to the confirmation of any resolution of assembled owners, or to the purchase by the Native Land Purchase Board, or to any exchange of Native land, notwithstanding the fact that any Native may thereby become landless within the meaning of this Act; and thereupon the said confirmation, purchase, or exchange may take place and shall have effect in the same manner as if that Native retained Native freehold land sufficient for his adequate maintenance.

(2) No such consent shall be given except on the recommendation of the Native Land Court or the Māori Land Board of the district in which the land is situated.

(3) No such consent shall be given unless the Governor is satisfied that the said Native is able to maintain himself by his own means of labour, and that the transaction consented to is not contrary to the public interest [emphasis added].

Subsection 1 suggests that alienating inalienable land was permissible regardless of whether Māori owners retained land elsewhere. This effectively suggests that if an owner is rendered landless by Court action, the Court ignores this fact and acts as if the owner was not in fact landless, or in layman's terms - turns a blind eye to the obvious, to meet the required ends. Subsection 3 suggests that the notion of maintaining land for Māori and their descendants was only permissible if it did not interfere with the public interest. This was in sharp contrast to the precepts of the Land Settlement Promotion Act of 1952 that actively provided for the retention of land by (ostensibly Pākehā) farmers and their children. It followed then that Judge Brook found the inalienability clauses a barrier to productively farming Lot 512 .

As part of the Māori Land Court rules, the Judge was also required to bring the title up to date by ensuring that deceased owners were succeeded and wherever possible, 
addresses for living owners were known. In the 1960s, that responsibility was with the proposed lessee or purchaser. ${ }^{608}$

For Lot 512, the restriction of inalienability was removed by Judge Brook on the $19^{\text {th }}$ of September 1961 under Section 80 of the Māori Purposes Act 1931 which states that:

80. Whereas various areas of Crown land have from time to time been marked on public maps and otherwise indicated as being allocated or set apart for Native purposes: And whereas doubts have arisen as to the authority for and the purpose of setting apart of many such areas of land: Be it therefore enacted as follows :-

(7) By any order made under subsection two hereof, or by any subsequent order of the Court, the Court may in respect of any land dealt with under the jurisdiction conferred by this section prohibit or restrict, in such manner as it thinks fit, the exercise of any powers of alienation contained in the principal Act, and the Court may at any time and from time to time remove or vary any such prohibition or restriction. ${ }^{609}$

This restriction was only removed for Lots 512A, B, C and F and only with regard to providing a lease on any of those blocks. ${ }^{610}$ On 21 September 1961 however, Judge Brook went further to ensure the sale of Lots $512 \mathrm{E}$ and F.

\section{The sale of Lots $512 \mathrm{E}$ and $\mathrm{F}$ in the national interest}

By discharging all possible restrictions to the sale of Lots $512 \mathrm{E}$ and $\mathrm{F}$, there were no further barriers to selling the blocks. That being the case, and against practice at the time, Judge Brooks took the usual step by firstly declaring the land at Lot 512 waste

\footnotetext{
${ }^{608}$ Blair, N.A (1967) to Robert Urquhart, 'Parish of Whangamarino 512D Section 2 - Styles Enterprises Limited, 25 October 1967, Māori Land Court (BACS), series 4948, 81, Archives New Zealand, Auckland.

${ }^{609}$ Section 80(7), Maori Purposes Act 1931.

${ }^{610}$ Judge Brook, 'Order for Removal of restrictions on alienations: In the matter of the lands known as Parish of Whangamarion Lot 512A, 512B, 512C, 512F', Mercer Minute Book, Volume 35, Māori Land Court, 19 September 1964, p.84.
} 
land. The Māori Affairs Act of 1953 has no mention of waste land nor does it require land to be declared waste land as a precursor to alienation. In doing so, Judge Brook invoked a term that had been used in the 1860 s prior to the Waikato invasion as a means to confiscate land that was considered unoccupied and unutilised. On both counts, this was not the case in Pōkaewhenua in the 1960s. Regardless, Judge Brook decided the following:

...that these two areas are virtually wase [sic] land

(a) Have been very poorly farmed in the past

(b) Are non revenue producing

(c) Area menace to the adjoining land, in as much as noxious weeds abound on them

(d) Should, in the national interest as well as in the interest of the owners, be brought into production but that this can only be effected by a sale to a practical and young farmer capable of developing them by hard work

(e) Should not be reserved from sale until the undoubtedly distant date when they and other Blocks in the 512 subdivision (total 365 acres) may be developed as one sheep farm or as three dairy farms. The Development Officer recommends confirmation as the costs of development and settlement are today too high for the average Māori settler and there would be no prospect of obtaining from the Board of Māori Affairs aloan [sic] of the large amount which development would require.

The Court has therefore reached the conclusion that it would be contrary to the interests of the owners to refuse confirmation...The Court, having reached the conclusion above, hereby removes such restriction [of inalienability except by will] from both blocks. ${ }^{611}$

\footnotetext{
${ }^{611}$ M.A Brook, 'Whangamarino 512E, Whangamarino 512F - Resolution to sell to R.J Ellmers', Waikato Maniapoto Minute Book, Vol 4, 21 September 1961, pp.284-6.
} 
There are a number of anomalies in Judge Brook's ruling, the key anomalie as mentioned above, being the declaration of Lot $512 \mathrm{E}$ and $\mathrm{F}$ as waste land despite the land being occupied and productively farmed by its owners. There being no evidence of poor farming by the owners, there remained instead an imagined perception that farming for one's livelihood was counter to productive farming for profit. This perception was at odds with the practice of whānau who operated a dairy farm on the land which continued to provide the local churnery with milk products as well as a tabacco plantation and market gardens that provided a wide range of fruit and vegetables. ${ }^{612}$ There were also no complaints by adjoining Māori owners regarding noxious weeds given the 'weeds' referred to included traditional mahinga kai such as pūhā, aruhe and native plants used for medicinal purposes. Also, no other candidates had been put forward other than Ellmers therefore the open tender process had been superceded by a process where Ellmers was the only candidate and preferred choice.

The evidence provided in point (e) above was erroneous as previously stated, given the assessment was based on the utilisation of the entire Lot 512 block not partitioned blocks such as Lots 512E and F. Lastly there is no evidence from the Māori Land Court records that the interests of all the owners were canvassed (see point 5 above) and the information provided to owners beforehand did not convey the possibility of outright sale or alienation through the agency of the Māori Trustee.

The national interests argument was utilised as the means to alienate the blocks as it was based on an economic premise influenced by government policy and a criteria applied by the Lands and Survey Department pertaining to young qualified farmers utilising scientific farming practices. ${ }^{613}$ Judge Brook considered it contrary to the owners' interests to refuse confirmation. The latter suggests that the Judge was well versed in the owners' interests by alienating their land on their behalf. This is highly unlikely given their opinion was never sought.

This notion of owners' interests will be covered in more detail later, but by removing the restrictions on the blocks, there was no protection for the Māori owners or their

\footnotetext{
${ }^{612}$ Ngawini Puru, Interview, 4 October 2011, Auckland.

${ }^{613}$ See Chapter 5.
} 
descendants, a right afforded to non-Māori farmers under the Land Settlement Promotion Act 1952. On 21 September 1961, Judge Brooks confimed the sale of Lot $512 \mathrm{E}$ by 6 of the 52 owners holding less than $1 \%$ of the shareholding and Lot $512 \mathrm{~F}$ was sold by 9 of the 37 owners or $25 \%$ of the shareholdng to Ellmers. ${ }^{614}$ Lot $512 \mathrm{E}$ was sold for $£ 1,957.10 .0$ or $£ 23$ per acre and Lot $512 \mathrm{~F}$ sold for $£ 1,660$ or $£ 25$ per acre. This was still $£ 17.72$ and $£ 15.72$ less per acre respectively than General land in the area

Having disposed of Lots 512E and F, the reference to the consolidation of the remaining Lot 512 blocks by Judge Brook and the District Officer suggest that other applications of alienation were already been filed to ensure the remaining partitions were also brought into production.

\section{Consolidation of remaining blocks (Lots 512B, C and D)}

The sale of Lots 512E \& F had a flow on effect with the remaining Lots 512A, B, C and D blocks. In 1961, Judge Brook mentioned that an application to consolidate the remaining Lot 512 blocks was in train and consideration be given to the impact the sale of Lots $512 \mathrm{E}$ and $\mathrm{F}$ had on any development scheme for the remaining blocks. ${ }^{615}$ On the 3rd of October 1963, Judge Brooks ruled that "none of the blocks would by itself be an economic holding but each would be best used with adjoining land". ${ }^{616}$ Should the owners decide against selling, the Māori Trustee was authorised to act as their agent to negotiate a lease for a period of 21 years. ${ }^{617}$

In reflecting on the District Field Supervisor's report and Judge Brook's comments for Lots $512 \mathrm{E} \& \mathrm{~F}$, it appears that the entire Lot 512 block was already being considered for farming development and an application to bring this into fruition was fait accompli. ${ }^{618}$

\section{Alienation by sale or lease: Lots 512B, C and D2}

\footnotetext{
${ }^{614}$ M.A Brook, 'Whangamarino 512E, Whangamarino 512F to R.J Ellmers', pp.284-6 and Maori Land Court, Block file for the Parish of Whangamarino Lot 512 (W1381), Maori Land Court Office, Hamilton ${ }^{615}$ M.A Brook, 'Whangamarino 512', Auckland-Thames Alienation Minute Book, Volume 1, January 1961, p.272 and M.A Brook, 'Whangamarino 512E, 512F -to R.J Ellmers', pp.284-6.

${ }^{616}$ M.A Brook, 'Whangamarino 512B, Whangamarino 512C, Whangamarino 512D2 - Applications for meetings to consider sales to Harvey', Waikato Minute Book, Vol 5, 3 October 1963, p.193. ${ }^{617}$ Ibid.

${ }^{618}$ Brook, 'Whangamarino 512', p.272 and Brook, 'Whangamarino 512E, Whangamarino 512F Resolution to sell to R.J Ellmers', Waikato Maniapoto Minute Book, Volume 4, 21 September 1961, pp.284-6.
} 
On 10 July 1963 an application was received by the Māori Land Court on behalf of Lloyd Kelton Harvey to purchase Lots 512B (47 acres), 512C (39 acres) and 512D2 (94 acres). Valuations of all three blocks were undertaken showing the following:

\section{Improvements Unimproved Capital}

$\begin{array}{llll}\text { Whangamarino 512B } & £ 330 & £ 1060 & £ 1390 \\ \text { Whangamarino 512D } & £ 800 & £ 1800 & £ 2600 \\ \text { Whangamarino 512C } & £ 360 & £ 800 & £ 1240^{619}\end{array}$

On considering the application for alienation, Judge Brook having adjourned the Court hearing to consider the valuation argued that in his opinion, the blocks would be better utilised together rather than separately. ${ }^{620}$

However, nearly half the owners for Lots 512C and 512D2 had unknown addresses and as noted previously the onus was on the applicant for alienation to update the list to better allow a majority of the owners to attend a meeting. Judge Brook saw no reason to further delay the meeting of owners by requiring an updated owners' list and authorised a meeting of owners "in each case despite this inadequacy". ${ }^{621}$ Should the resolutions for sale in those meetings not eventuate, Judge Brook directed that Section 308(2)/53 be utilised. Brook argued that

it may be that the owners' best interest would best be served by a lease of all three blocks to the applicant. ${ }^{622}$

As mentioned previously, Section 308(2) allows for a resolution for alienation at an owners' meeting and where that fails, to then have the Māori Trustee appointed as an agent to facilitate a sale or lease.

\footnotetext{
${ }^{619}$ P J Ovington to J C Black, 'Whangamarino 512B, 512C and 512D Blocks', 30 September 1963, Māori Land Court (BACS), series 4948, 81e, Archives New Zealand, Auckland.

${ }^{620}$ Brook, 'Whangamarino 512', p.272.

621 Ibid..

${ }^{622}$ Ibid.
} 
Judge Brook then provided an alternative resolution for consideration: that the blocks be leased for 21 years to Harvey, without a right of renewal at a rate of $6 \%$ of the proposed sale price that was offered. The lease figures proposed for the blocks were $£ 400$ for Lot 512B ( $£ 8.50$ per acre), $£ 450$ for Lot 512C (£11.53 per acre) and $£ 950$ for Lot 512D2 (£10.10 per acre). ${ }^{623}$ The meeting of owners for all three blocks was held on 30 October 1963.

\section{Lot 512 B}

The owners of Lot 512B rejected both the resolutions to sell or lease to Harvey and resolved to adjourn the meeting until they found out what Lot $512 \mathrm{C}$ had decided. ${ }^{624}$ On 7 August 1964, Henry de Thierry, an existing owner in Lot 512B applied to summon a meeting of owners to have Lot $512 \mathrm{~B}$ sold to him instead. ${ }^{625}$ In the meantime, a Section 108, Rating Act charging order had been submitted to the Māori Land Court and on 24 November, one of the owners in attendance, Tamehana Kahi, agreed with Foster (a County Clerk) to a charging order against the block. Although Kahi was not in occupation on the block at the time, the charging order of £14-15-4 (plus a 10/- fee) was charged in favour of the Waikato County Council. ${ }^{626}$

On 30 November, the block was back in the Māori Land Court to confirm the sale of Lot $512 \mathrm{~B}$ to de Thierry for $£ 1600$ (or $£ 34$ per acre). With six owners (out of 37 ) in attendance, holding less than $26 \%$ of the shares, Judge Brook was convinced that the sale should proceed. ${ }^{627}$ It should be noted that in the sale of Lot $512 \mathrm{E}$ and F to Ellmers, the cost was $£ 23-25$ per acre, in comparison to $£ 34$ per acre paid by de Thierry, an existing owner in the block.

\footnotetext{
${ }^{623}$ Brook, 'Whangamarino 512B...512C...512D2 to Harvey', p.193.

${ }^{624}$ P.J Ovington to J.C Black, 'Whangamarino 512B' re Statement of Proceedings of Meeting of Assembled Owners, 30 October 1963, Māori Land Court (BACS), series 4948, 81e, Archives New Zealand, Auckland.

${ }^{625}$ H.N De Thierry, 'Parish of Whangamarino Lot 512B', Application to summon a meeting of owners, 7 August 1964, Māori Land Court (BACS), series 4948, 81e, Archives New Zealand, Auckland.

${ }^{626}$ M.A Brook, 'P/Whangamarino Lot 512B', Mercer Minute Book, Volume 43, 24 November 1964, p.122.

${ }^{627}$ M.A Brook, 'Whangamarino 512B' re Order confirming Resolution of Assembled Owners, 30 November 1964 and M.A Brook, 'Whangamarino 512B - Resolution to sell to Henry Noel de Thierry', Mercer Minute Book, Volume 43, 30 November 1964, pp.147-148.
} 
In August 1968, de Thierry applied to the Court to lease his block to David Styles, only to discover that the Court was in the process of Europeanising his land under the Māori Affairs Amendment Act 1967, which automatically changed Māori land to general land where there were four or fewer owners. ${ }^{628}$ It would appear from the records that this did eventuate on 3 September 1968, wherein all records for the block cease until it was reverted back to Māori land in 1987. No buildings or homes were ever erected and from 1968 it has been in a farm lease since that period. An Ahu Whenua Trust was established in 1994 and continues to administer the lease of Lot 512B, much like the Ahu Whenua Trust eventually created for Lot 512C.

\section{Lot $512 \mathrm{C}$}

An investigation of the Lot 512C block in 1960 had failed to implement either a lease or sale. In June 1964, the County Clerk with the Waikato County Council, Malcolm Patteson Goldsbro, applied to the Māori Land Court under Section 33 of the Māori Affairs Act 1953 and section 108 of the Rating Act, to become the Receiver for Lot $512 \mathrm{C}$ for failure to pay $£ 11$ in rates. ${ }^{629}$ Under Section 33 , failure to pay rates did not mean the land passed out of Māori ownership, instead, the Māori Land Court may appoint either the Māori Trustee or "any other fit person to be a receiver in respect of that property". Subsection 3 states that

(3) A receiver appointed under this section shall have all the rights, powers, duties, and liabilities as may be expressed conferred or imposed on him by the Court and such other incidental powers as may be reasonably necessary for the exercise of the powers so conferred...

Unlike Lot 512B where charging orders were made but the land remained with the owners until the block was sold to de Thierry, in Lot 512C, the receiver had the power under this section of the Act to grant leases of land for up to 21 years in order to recuperate any outstanding debt. In effect, the County Clerk in this instance was no different from the Māori Trustee. Under Section 108 of the Rating Act, Foster, also

\footnotetext{
${ }^{628}$ N.A Blair to Messrs McDermott and McIntosh, 'Allotment 512B Parish of Whangamarino: H.N de Thierry to D.J Styles', 20 August 1968, Māori Land Court (BACS), series 4948, 81e, Archives New Zealand, Auckland.

${ }^{629}$ Foster, Mr, 'P/Whangamarino Lot 512C', Mercer Minute Book, Volume 42, 9 June 1964, p.356.
} 
advised that he had been chasing rates payments, unsuccessfully, from the owners and given the block was considered unoccupied, he argued that the block

could be revenue producing but owners seem unable to agree...Ellmers purchased 2 similar blocks some years ago and is developing same [sic]. ${ }^{630}$

In reality, the land was occupied by Rawinia Shelford, Te Ao Mārama's daughter and the whare they were living in on Lot 512C, was Te Ao Mārama's whare. Furthermore, it seems excessive to require a 21 year lease of Lot $512 \mathrm{C}$ to recover $£ 11$ worth of rates from the owners. Regardless, at the following Court hearing on 18 June, Mr Foster convinced Peter Iwihora (an owner in Lot 512C) to agree to a charging order and appointment of a receiver. As the only owner present, and with no indication or evidence that other owners were consulted or advised, Foster's pressure on Iwihora to agree to a charging order, was manipulative and underhanded. ${ }^{631}$ Neither Foster nor Iwihora had the authority to agree to a charging order or the appointment of a receiver but with outstanding rates of $£ 11$, Judge Brook appointed Malcolm Patteson Goldsbro, a Country Clerk in Huntly "as receiver for the [purpose] of enforcing charge, with the power to lease for not more than 15 years". 632

Essentially, where the owners' meetings had failed to bring the land back into production, the use of the Rating Act to charge for rates and enforce agency for alienation, appears to have been a far more successful avenue.

Coincidentally, another applicant seeking to purchase Lot 512C, Caie, withdrew his application from the Māori Land Court and by October that same year, Goldsbro (the County Clerk) leased Lot $512 \mathrm{C}$ to Caie for $£ 74$ ( $£ 1.89$ per acre or $6 \%$ of $£ 1,240)$ for 5 years and then $5 \%$ of the valuation for another 5 years ( $£ 62$ or $£ 1.58$ per acre) with no rent in the final 5 years in exchange for no payment for any improvements made. ${ }^{633}$ Over the 15 -year lease period, the owners received $£ 680$ or $54 \%$ of the actual value at a rate of $£ 1.15$ per acre, per year. This rate of $£ 1.15$ is in line with Lot $512 \mathrm{E}$ and F's lease

\footnotetext{
${ }^{630}$ Foster, 'P/Whangamarino Lot $512 \mathrm{C}$ ', p.356.

${ }^{631}$ Ibid and Foster, 'P/Whangamarino Lot 512C', Mercer Mintue Book, Volume 43, 18 June 1964, p. 33

${ }^{632}$ Foster, 'P/Whangmarino Lot 512C', Volume 43, p.33.

${ }^{633} \mathrm{Mr}$ Patterson, 'P/Whangamarino Lot 512C', Mercer Minute Book, Volume 43, 17 September 1964, p.109 and Patterson, 'Whangamarino Lot 512C', Mercer Minute Book, Volume 43, 22 October 1964, p. 112 .
} 
proposal of $£ 1.29$ and $£ 1.51$ respectively. The accepted lease rate at the time was between $6-10 \%$ of the valuation which could have returned $£ 124$ per year or at least $£ 3$ per acre.

Having put Lot 512C into production, the Waikato County Council applied to the Māori Land Court in July 1965 to remove the Charging Order that made it a receiver but this did not come into proper effect until 1980 when the lease expired. Until 1980, the Charging Order remained as a lien against the block, for no discernible reason.

In 1986, an Ahu Whenua Trust was created appointing five of its owners as Trustees however, this block has not come out of lease since it was forcibly put into production in 1965.

It is excessive to say the least, to forcibly alienate land from its Māori owners for 15 years over $£ 11$ owing in rates. To add insult to injury, the owners received $£ 680$ less their portion of the survey costs and the outstanding $£ 11$ in rates. In the end, the owners were fortunate to receive $£ 500$ over 15 years at $£ 0.85$ per acre in addition to being forcibly removed from their land.

\section{Lot 512 D 2}

On 10 July 1963 an application by Harvey was also submitted to the Māori Land Court to purchase Lot 512D2 for $£ 3,000$ or $£ 31.94$ per acre. Judge Brook’s directions of 4 September ${ }^{634}$ also applied to Lot 512D2 and at the owners meeting on 30 October 1963 , both the resolution to sell and to lease were rejected by the majority of owners. ${ }^{635}$ Those in favour of selling were Te Ata Tukirunga, Rangimarie Ahuahu and Turoa te Ahuahu. Those against were Kahi Te Puru, Te Kere Waikato, Moki te Puru, Pakipaki te Puru, Rawinia te Puru (all of whom were Te Ao Mārama's children) as well as Mata Tukirunga and Tuhewa Hemi. ${ }^{636}$

\footnotetext{
${ }^{634}$ M.A Brook, 'Whangamarino 512B...512C...512D2', Waikato Alienations Minute Book, Volume 5, 4 September 1963, p.193.

${ }^{635}$ P.J Ovington, 'Whangamarino 512B' re Statement of Proceedings of Meeting of Assembled Owners, 30 October 1963, Māori Land Court (BACS), series 4948, 81e, Archives New Zealand, Auckland. ${ }^{636}$ Ibid.
} 
On 19 October 1967, Styles Enterprises Limited also applied to summons a meeting of owners to have Lot 512D2 block sold to them for the price of $£ 7,000$ ( $£ 74.46$ per acre), or failing that, to have the block leased to them for a period of 21 years at $£ 140$ per year or $£ 1.48$ per acre. A Special Valuation of Lot 512D2 on February 1968 showed that the Capital Value was $£ 7,300$ and based on the $6 \%$ rental, ${ }^{637}$ the minimum rental per annum based on the 1968 valuation, should have been at least $£ 438$ or $£ 4.65$ per acre.

On 26 March 1968, Lot 512D2 block was brought before Judge Brook to consider Styles Enterprises Limited's resolution. At that hearing, three owners had engaged a solicitor to represent their interests. In considering the resolution to sell, the Noxious Weeds Inspector was also in attendance to advise that the block was, in the main, covered in "titree [sic] and blackberry" with approximately 25 acres (of 92) of land disc-ed by tractor and cropped". ${ }^{638}$ In the Inspector's opinion, there was "no leasing policy of owners, occupiers have taken all and returned nil, reversion bad, no reticulation, served only by springs". 639

The Inspector argued that the owners had no funds to purchase or graze stock and

suggested that lease for several years (ratified by Court) requiring good English grasses and annual application of manure; estimated cost of bringing land into production $£ 120$ per acre - total including fencing and water reticulation $£ 11,040$; would have to be farmed with another unit to effect improvements economically. ${ }^{640}$

An Accounts Clerk from the Waikato County Council was also present to attest to owner occupiers failing to pay rates on the block. The Clerk argued that Rawinia Shelford (daughter of Te Ao Mārama) and her husband moved on to the block in 1964 after a previous owner occupier had left and that Rawinia had been living in an earthen floor whare, before moving into her mother's cottage on Lot 512C. In October 1967,

\footnotetext{
${ }^{637}$ M.A Brook, 'Whangamarino 512B...512C...512D2', p.193.

${ }^{638}$ Darby Finlayson in M.A Brook, 'Lot 512D2 Parish of Whangamarino - Section 438', Waikato Minute Book, Volume 46, 25 March 1968, p.141.

${ }^{639}$ Ibid.

${ }^{640}$ Ibid.
} 
the Clerk confirmed that an application had been filed (supposedly by the Council) to have the Māori Trustee appointed under Section 387.

Section 387, falls under Part XXV of the 1953 Act and reads as follows:

(1) Where, with respect to any Māori freehold land or European land owned by Māori s [sic], the Court is satisfied -

(a) That the land is unoccupied; or

(b) That the land is not being kept properly cleared of weeds which in the locality in which the land is situated are noxious weeds within the meaning of the Noxious Weeds Act 1950; or

(c) That any rates payable in respect of the land, or any moneys recoverable in the manner in which rates are recoverable, have not been paid, and that the amount of the said rates or moneys has been charged upon the land; or

(d) That the owners of the land have neglected to farm or otherwise manage the land with due diligence and that in consequence of their neglect the land is not being used to proper advantage, -

it may on application by the local authority of the district or by any person interested make an order in respect of that land or a defined portion thereof appointing the Māori Trustee to be the agent of the owners for the purposes of this Act.

(4) No order appointing the Māori Trustee to be the agent of the owners for the purposes of this Part shall be made by the Court unless it is shown to the satisfaction of the Court that the land is, by ordinary and reasonable standards, capable of being used with advantage for agricultural or pastoral or horticultural purposes or for the production of food products or for dairy 
farming or the keeping of pigs, bees, or poultry, or for a combination of any two or more of such purposes.

However, both the Council and the Noxious Weeds Inspector appear to have ignored the fact that Lot 512D2 was in occupation by Tamehana Puru (Te Ao Mārama's son and Rawinia's sibling) as well as other whānau members and that at least 25 acres of the block was planted in crops. The Noxious Weeds Inspector had attested to those 25 acres in his evidence to the Court.

Furthermore, a letter form the Council in October 1967 to owners, stated that the land was in a poor state which resulted in Joseph (Raungohi) ${ }^{641}$ and Ngawini Puru, Rangi Puru (their son) and Te Kere Nepe (Raungohi's older brother), approaching the Council to advise that Joseph's shares would be given to Te Kere so that he could farm the block. ${ }^{642}$ At that time Lot $512 \mathrm{D} 2$ had outstanding rates of $£ 38 .{ }^{643}$

On determining Nepe's ability to farm the block, Nepe gave evidence which showed that he had several years dairying experience and had been doing so since the age of 15 . His ability to access finance however had not been tested with the Department of Māori Affairs at that time but Nepe maintained that he was capable of farming the land and other owners had agreed to transfer their shares to him to allow greater security in the block. ${ }^{644}$ However, at the conclusion of the court hearing, Mr Palmer (Waikato County Council officer) argued that Nepe had

not shown to the Court that proposed lessee has adequate finance and experience to deal with this Block; in his own interests it is not desirable that he should do so - he would be in danger of losing what little he did put in through lack of money to complete. Shown that no buildings on land and cost of development plus buildings would be much greater than that estimated. I submit that in interests of all the owners it is desirable that a

\footnotetext{
${ }^{641}$ Joseph Raungohi Puru was a whangai son of Te Ao Mārama, but also a natural grandson through Te Ao Mārama's daughter, Rawinia Shelford, who was his mother. See whakapapa table on page 206.

${ }^{642}$ Te Kere Nepe in M.A Brook, 'Lot 512D2 Parish of Whangamarino: Section 438', Māori Land Court, Waikato Minute Book, Volume 46, 26 March 1968, p.141.

${ }^{643}$ Ibid.

${ }^{644}$ Ibid.
} 
proper lease be arranged to a farmer with adequate capital to develop the land [emphasis added]. ${ }^{645}$

Palmer makes a bold statement by attesting to know the owners' interests. It is unlikely that he knew Nepe personally, so it stands to reason that in articulating his knowledge of Nepe's and "all the owners" interests, he is referring more to an 'imagined' understanding of Māori interests as opposed to an actual understanding. This concept will be discussed in more detail shortly, but it highlights a continuing paternal attitude by government agents in determining what and whose interests they were claiming to advocate. Furthermore, Nepe fell within the Māori Affairs lending criteria of up to $£ 16,000$ for Māori land. With his experience and possible funding ability, there was no perceived reason from an owners' perspective for Nepe to be declined as a leasee for the block. In reality however, Nepe did not meet Lands and Survey's criteria of technical training that would have made him a preferred candidate.

On 13 June 1968, Styles Enterprise Limited requested a refund of their application fee following a Section 438 order to have the Māori Trustee appointed to lease the block. ${ }^{646}$ More importantly, Robert Urquhart, in support of Styles, referred to the alienation of Lots 512E and F noting "no great improvements to the Block" and that the County Council had previously taken an interest, presumably for rates. ${ }^{647}$ According to Elsie Davis, those owners living on the block were then evicted so that a "proper lease" could be implemented. ${ }^{648}$

So despite occupation and productive use by the owners in crops and dairy farming, the Court still appointed the Māori Trustee on 13 June 1968 who then leased the block to BH and HE Periam for 21 years from 19 September 1968 .

\footnotetext{
${ }^{645}$ Mr Palmer in M.A Brook, 'Lot 512D2 Parish of Whangamarino: Section 438', Māori Land Court, Waikato Minute Book, Volume 46, 26 March 1968, p.141.

${ }^{646}$ Robert Urquart, 'Lot 512D2 P/Whangamarino', Waikato Minute Book, Volume 46, 13 June 1968, p.245.

${ }^{648}$ Maki (Elsie) Davis to Sue Maruiohoho (Ngā Marae Topu) and John Te Maru (Tainui Māori Trust Board), 20 October 1995, Private Papers.
} 
Lot 512D2 remained under lease with the Māori Trustee until 1990 when an Ahu Whenua Trust was created ${ }^{649}$ and owner Trustees became directly responsible for the leasing of the block. Since 1990 however, and given the block's history and the owners' lived memories there, the Trustees have continuously leased to Pākehā farmers utilising the same template as directed in 1968. Although the current farmer (as at 2013) continues to over stock, over use and desecrate the marae and urupa grounds within the land block with his wandering stock, there is an unwillingness by the Trustees and kaumātua of the block to depart from the rules enforced in the 1960s.

\section{Consolidation Application by Deputy Registrar}

The alienation of Lot 512B, C and D by lease was cemented in an application by a Deputy Registrar under section 445 of the 1953 Act, which appointed the Māori Trustee on a number of Parish of Whangamarino blocks. On 2 September 1964, twenty four Parish blocks were transferred into the Māori Trustee's administration including Lots 512A, B, C and D2. ${ }^{650}$

This consolidated order vested the title of the land in the Māori Trustee and gave the Trustee the ability to acquire any uneconomic interests within the consolidated blocks. On 2 March 1965, Judge Brook (the same Judge responsible for the sale and lease of Lot 512) confirmed the consolidation order for the Parish of Whangamarino Lots 10, 210, 227, 229A, 233A, 233L, 283, 313, 314, 318, 319, 323B1, 393A2B, 393C, 393E, $393 \mathrm{~F}, 393 \mathrm{~J}, 393 \mathrm{~K}, 442 \mathrm{~A}, 442 \mathrm{C}, 512 \mathrm{~A}, 512 \mathrm{~B}, 512 \mathrm{C}$ and 512D2. ${ }^{651}$

The consolidation en mass of Parish lands, in the main, allowed the Māori Trustee to effectively lease or provide licences over vested lands at a rate determined by them, and according to the beneficial interests of the Crown, rather than its Māori owners. ${ }^{652}$ Lot 512A, as seen above, was one of those blocks.

\section{Lot 512 A: Māori Trustee}

\footnotetext{
${ }^{649}$ Māori Land Court, Waikato Minute Book, Volume 70, 'Whangamarino 512D2 Block: Section 438(3)(a) and (b)/53', 11 December 1990, pp.121-122

${ }^{650}$ Māori Land Court, Mercer Minute Book, Volume 43, 2 September 1964, p.68.

${ }^{651}$ Ibid and M.A Brook, 'Consolidation Order', Mercer Minute Book, Volume 43, 2 March 1965, p.213.

${ }^{652}$ Section 445, Māori Affairs Act 1953.
} 
Archival records for Lot 512A are currently sealed for a further 15 years and can only be accessed on application to the Māori Trustee. During the course of this thesis, I was advised that the application for access should contain information stating that I am either an owner, beneficiary or whakapapa to the block, and although this information has been provided on three counts, with supporting phone calls and emails, my requests have been ignored. At one point, I was advised that the files were sealed in the owners' best interest as they held sensitive information.

Much like Lots 512B, C and D, Lot 512A was transferred to the Māori Trustee to be put into production in the $1960 \mathrm{~s}$, resulting also in the subdivision of $512 \mathrm{~A} 1$, and continuous farm lease. The inability to access further information is a limitation of this thesis but it is clear during visits to Pōkaewhenua that the block has been in continuous lease since the 1960s, in the owners' best interest.

\section{In the owners' best interest}

It is difficult to see how the Court was acting in the owners' best interest when less than $30 \%$ of owners were consulted (Lots 512E \& F), if at all (Lots 512B, C and D) and bias was shown towards the few who were seeking to sell or those who were buying (Lots 512B, E and F). Other blocks in the Parish similarly affected in the same manner include Lots 277, 471B and 393.

There was no consideration by the Māori Land Court to partition out the shares that belonged only to the Māori sellers, allowing the remaining majority of owners to maintain their take noho or take tūpuna. Instead, the blocks in their entirety were valued and assessed on their ability to become economic units, or more accurately, economic farming units. The focus on farming and productive units marginalised those Māori owners who did not want to be alienated or those Māori owners who did not know about the sale and were not provided the opportunity to maintain their ownership or have a say in the land's alienation.

The ability for Judges to use their discretionary powers to change and/or waive restrictions which were originally designed to promote or protect Māori ownership was both unfair and unjust in its practice. There was no mechanism to protect Māori 
interests or allow fail safes to ensure descendants or beneficiaries to Māori land could retain their ownership - a process that was afforded and legislated for General land and Pākehā farmers.

The "interests of the owners" have been considered since 1858 and have seldom, if ever, been fully entrenched in government policy regarding Māori land unless it expressly furthered the interests of the government of the day or the groups it represented. In 1858, Governor Gore Browne doubted that Māori interests could be adequately represented particularly in light of settler demand for land or control of the growing colonial economy. Gore Browne wrote to Sir E. Bulwer Lytton arguing that

it may be asked...on what grounds one portion of Her Majesty's subjects could demand the right of governing another portion not allied to them by blood or interest and who are unrepresented in their councils...The expediency of subjecting the management of native affairs to the control of responsible ministers...is based upon the assumption that the interests of the natives may be safely confided to the Colonists; but this is an assumption not borne out by experience. ${ }^{653}$

In his reply, Bulwer Lytton concurred by stating that

A straightforward and equitable course of proceeding towards the Natives, especially in those negotiations which relate to the purchase or cession of land, is not only a matter of duty, but will, I am persuaded, be found to be most consistent with the interest of the colonists and the general peace and welfare of the colony. ${ }^{654}$

Gore Browne and Bulwer Lytton accurately conveyed the situation. The government in the nineteenth-century was unable to advocate adequately for Waikato interests and in understanding that, argued that failing in their ability to do so, those interests were then realigned, subsumed or made to be "consistent with the interests of the colonists".

\footnotetext{
${ }^{653}$ Governor Gore Browne to Sir E B Lytton, 'Further papers relative to Native Affairs (Memorandum of $29^{\text {th }}$ September, 1858)', AJHR, Session I, E-01, 1860, p.2.

${ }^{654}$ Bulwer Lytton in Hanson Turton, An Epitome of Official Documents Relative to Native Affairs and Land Purchases in the North Island of New Zealand, George Didsbury, Wellington, 1883, p.141.
} 
In 1913, the strength of Māori interests to reverse alienation was considered in the Court of Appeal. In Wilson v Herries $^{655}$ the issue of confirmation of sale was raised referring specifically to Section 220 of the Native Land Act 1909. The relevant parts of Section 220, and its subsections are as follows:

1. No alienation shall be confirmed unless the Board or Court is first satisfied as to the following matters:

(a) That the instrument of alienation has been duly executed in manner required by this Part of this Act.

(b) That the alienation is not contrary to equity or good faith, or to the interests of the Natives alienating.

(c) That no Native will by reason of the alienation become landless within the meaning of the Act.

2. If the Court or Board is satisfied as to all the matters referred to in this section a certificate of confirmation shall be granted as a matter of right.

It was found that the two subsections, 1 and specifically 1(b) that sought to protect Māori interests, had little weight against subsection 2. In addition subsection 3 of Section 278 exempted any sales by "private contract" to the restrictions set out in Section 220. ${ }^{656}$ Private contract sales were described in subsection (1) of Section 278 as:

.... a site for the erection of any building required for any religious, charitable, educational, or public purpose, or as a site for a dairy factory, cheese-factory, creamery, fruit preserving factory or industrial establishment.

\footnotetext{
${ }^{655}$ Wilson v Herries - [1913] 33 NZLR 417.

${ }^{656}$ Rachael Willan, 'Māori Land Sales, 1900-1930', Report for the Crown Forestry Rental Trust (Twentieth-Century Māori Land Adminsitration Research Programme), March 1996, p.19.
} 
Subsection 2 provided a measure of restraint by requiring an Order in Council alienation for any land purchase that exceeded five acres, however this restraint did little to ebb the flow of alienation.

Order in Council alienations were instigated by recommendations from the Māori Land Board by advocating that the alienation was justifiable. Parish of Whangamarino Lot 277 is a good example of an Order in Council alienation, which acted against the best interests of the owners.

\section{Lot 277}

Lot 277 is located parallel to Falls Rd and is tucked into the eastern side of Whataroa Maunga, with Pungarehu Stream running alongside its western boundary. The land was flat to undulating although in 1913 was considered poor and swampy land. ${ }^{657}$

An application from a neighbouring farmer, Margaret E Beale to have Lot 277 alienated, followed on the heels of a number of other alienations sought by her in the immediate vicinity including Lot 276 which bounded Lot 277 on three sides.

The original application to the Waikato Maniapoto District Native Land Board was rejected on 26 March 1913 on the grounds that the alienation would leave its two owners, Kauia Kauia (or Kauia Tamehana) and Kahutoroa Kuia "landless by reason of the alienation". ${ }^{658}$ In the minutes of the Native Land Court, the Judge is more emphatic by noting that

For the reason that the Natives are rendered themselves landless by vendor of this alienation, the Board cannot do otherwise than refuse confirmation. ${ }^{659}$

\footnotetext{
${ }^{657}$ W.H Bower to Office of the Waikato Maniapoto District Native Land Board, 'Whangamarino Lot 277', 24 June 1913, Māori Affairs (ACIH), series 16036, MA1/1103, ANZ, Auckland.

${ }^{658}$ W.H Bower to J.St Clair, Solicitor, 'Allot. 277 Whangamarino', 25 March 1913, ACIH, series 16036, MA1/1103, ANZ, Auckland.

${ }^{659}$ Waikato Maniapoto District Native Land Board, 'Lot 277 Whangamarino: Applicantion for confirmation of transfer to Margaret E.H.Beale' in Waikato Alienations Minute Book, Volume 9, 26 March 1913, pp.375-376.
} 
A documented assumption made by the applicant (Beale) and the Board is that neither owner considered the land of any use to them by virtue of their not occupying the block. Reference is made to the two owners living on Takapūruharuha (Lot 393) two kilometres south of Lot 277, as well as having access to other land in Pukekohe. ${ }^{660}$ In Bower's (President of the Waikato Maniapoto District Native Land Board) report to the Governor General, he describes the two owners as follows:

The first named is a woman of about 55 years of age, while the other is a woman of about 38. They are either widows or od [sic] not live with their husbands. Both generally live together, and have no children. The younger one earns a living at cutting flax and digging potatoes and is said to support the older. ${ }^{661}$

There appears to have been little investigative process to determine the background or interests of the two owners, as a preliminary enquiry with those living on Lot 393 would have informed the Native Land Board that Kauia was Kahutoroa's sister. Kauia had two children, one of whom, Te Ao Mārama, was living at Pōkaewhenua on Lot 512. Her younger child, Te Umawera, had recently died on 5 December 1912 (see Whakapapa 2). Te Umawera's interests and take whenua in Lot 393, although passed to her older sister, were being maintained by her mother and aunt, as was the Ngāti Hine fashion. Further investigation would have also uncovered that Lot 393 was situated on another important site for Ngāti Hine, the Takapūruharuha pā. This pā, along with Pōkaewhenua and Rangiriri were of cultural importance to Ngāti Hine and continued occupation by family members, by the likes of Kauia and Kahutoroa, kept the ahi ka in that area for Kauia's whānau.

\footnotetext{
${ }^{660}$ M.E.H Beale to W.H Bower, 'Re Allot. 277 P/Whangamarino - 30 acres', 7 February 1913, ACIH, series 16036, MA1/1103, ANZ, Auckland. See also Wilkinson, 'Mistake as to position of Takapūruharuha', 23 October 1890, for confirmation that Takapūruharuha is located on Lot 393, BAAZ, series $1108,58 \mathrm{a} / 2005$.

${ }^{661}$ Bower, 'Lot 277', 24 June 1913, ACIH, series 16036, MA1/1103, ANZ, Auckland.
} 
Although the initial application to alienate was rejected, the applicant applied again on 15 May 1913 for a recommendation for an Order in Council to alienate Lot 277 and

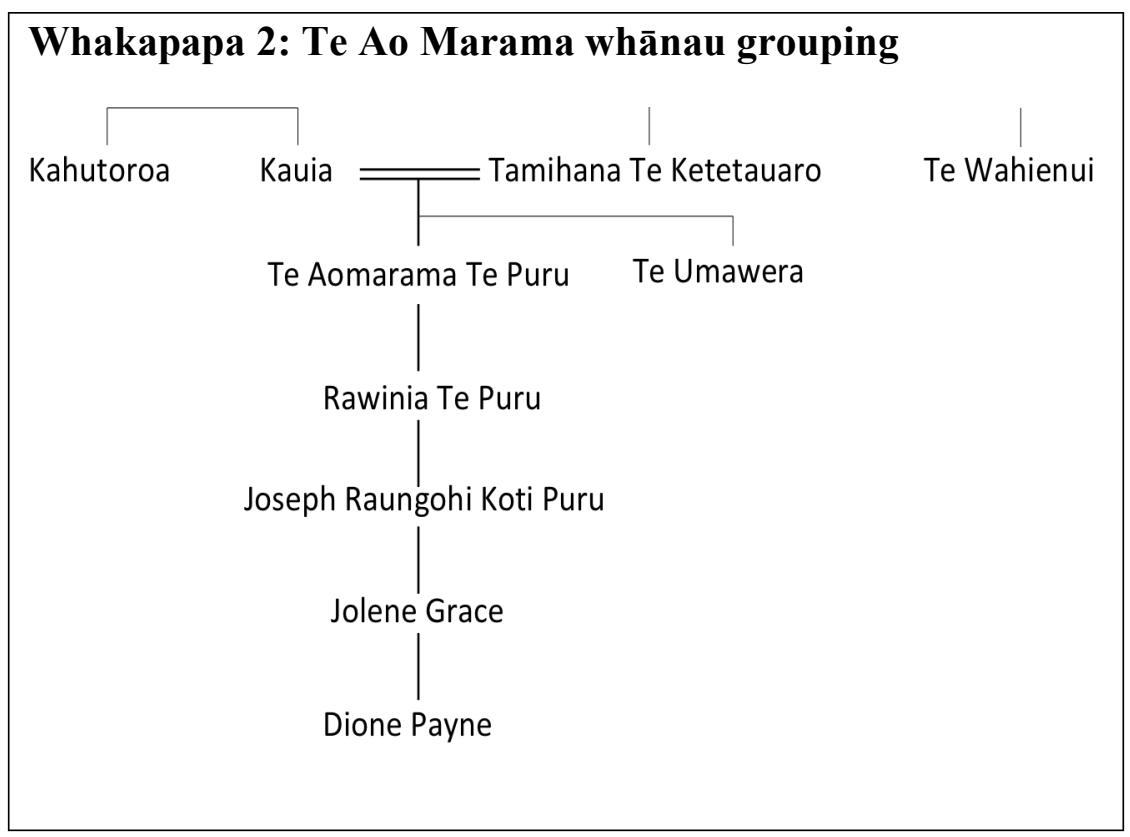
dispense "with the necessity of Providing other lands for the occupation of the Vendors". ${ }^{662}$ On the $10^{\text {th }}$ of June, the Native Land Board considered Beale's application and although the Board had previously

stated that it could not "do otherwise than refuse confirmation", decided three months on, to recommend Beale's application to the Native Department. The Board seemed little more informed and left the stating of the case to Beale's solicitor, St Clair, who had spent no time during those three months to find the owners or get more information on their status. Instead St Clair sums up the owners' situation as follows:

There are two owners. Both are being made landless by this sale. They live some distance from this block. Land has no access, [and] is right in the middle of Mrs. Beale's block. Kauia Kauia is a woman of about 55. Think she is a widow. Has no children. Kahutoroa Kauia is a woman of perhaps 38. Think she has a husband but does not live with him. She earns a living cutting flax and digging potatoes. Kauia Kauia generally lives with her. Neither of them has ever made any use of this land. Block is poor country -

\footnotetext{
${ }^{662}$ J. St Clair, 'Whangamarino Lot 277: Application for a recommendation for Order in Council dispensing other lands", Application to the Waikato Maniapoto District Native Land Board, 13 May 1913, ACIH, series 16036, MA1/1103, ANZ, Auckland.
} 
swamp and low fern hills. They live generally on Sec 393 Whangmarino

[sic]. Have a whare there, but no cultivations. ${ }^{663}$

Much like Bowen's statement, the inaccuracies remain. Both women were living two kilometres south of Lot 277 and a visit to Lot 393 would have been adequate to consult with the owners. Te Ao Mārama was living at Pōkaewhenua and Kahutoroa also had two children, and was Kauia's sister. The lack of effort to consult with the owners, knowing that the sale would render them landless seems rather callous.

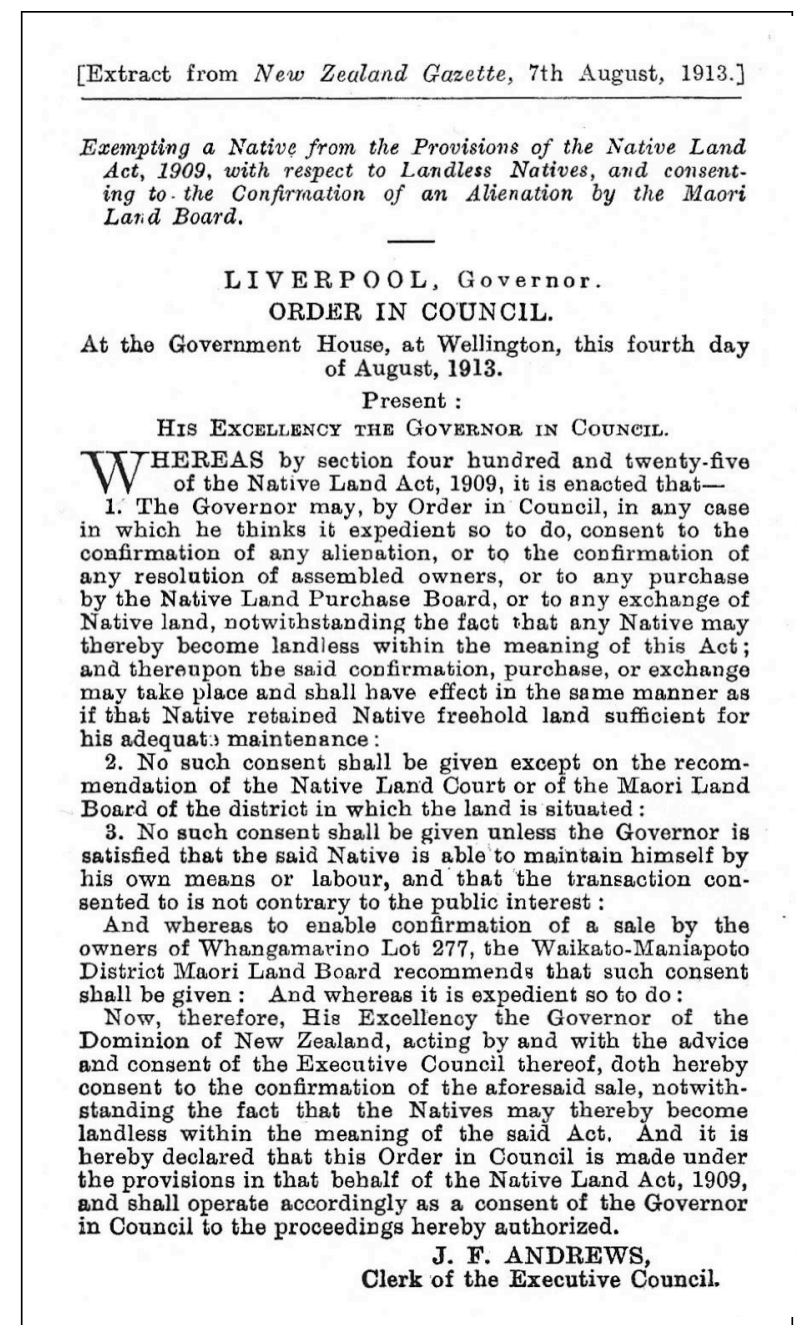

On 24 June 1913, the President of the Waikato Maniapoto Māori Land Board recommended "that it would be in the interest of all parties if the sale could be effected"664 and on 4 July, Beale's solicitor was advised that the Board was supporting the application for an Order in Council and subsequently wrote to the Under-Secretary of the Native Department for forwarding to the Native Minister for approval. ${ }^{665}$

The Order in Council dispensed with the "necessity of providing other lands for the occupation of the vendors"666 and although other lands were listed in an attachment schedule as belonging to Kauia and Kahutoroa (Lots 393 and 473), title confirmation for both blocks had yet to be granted and the sale therefore to Beale did effectively make them landless.

\footnotetext{
${ }^{663}$ J. St Clair, 'Lot 277 Whangamarino - 30 acres: Application for recommendation under Section 425 for Order in Council dispensing with Other Lands re sale to M.E.H Beale' in Waikato Alienations Minute Book, Maori Land Court, Volume 10, 10 June 1913, pp.113-114. ${ }^{664}$ Bower, 'Lot 277', 25 March 1913, ACIH, series 16036, MA1/1103, ANZ, Auckland. ${ }^{665}$ Ibid.

${ }^{666}$ J. St Clair, 'for Order in Council dispensing other lands", 13 May 1913, ACIH, series 16036, MA1/1103, ANZ, Auckland.
} 
On 7 August 1913 a Gazette notice was issued as seen in the Extract from the New Zealand Gazette confirming the Order in Council alienation of Lot 277 from Kauia and Kahutoroa to Beale..

Although the Order in Council was gazetted on 7 August, the requirement to ensure that payment was provided to Kauia and Kahutoroa was not made a legal stipulation in the Court until 26 February 1914. The Board made it clear that the application would only be confirmed if the purchase money was provided to the two owners and receipts provided. ${ }^{667}$ This suggests one of two things: either the owners refused to sign for the money and therefore acknowledge the sale of their land; or the purchaser had not considered that they had to pay the money to the supposed 'vendors'.

Five and half months after the sale was processed, a receipt was finally signed by Kauia and Kahutoroa confirming that a sale had been affected. ${ }^{668}$ It appears that as a fait accompli, Kauia and Kahutoroa either accepted the money as payment for land that had been sold without their consent through an Order in Council or went without. Either way, the land was no longer in their possession and all that remained was the money held in Trust by Beale's solicitors until it was collected by Kauia and Kahutoroa.

The Māori Land Board, as has been seen earlier, has decided what is in the interests of all parties including the owners. As was discussed earlier, the owners interests whether known or not, were subsumed by the interests of the applicant and as was stated in this Order in Council alienation, "is not contrary to the public interests". At no time is there evidence that the owners were consulted or consented to the alienation. The evidence provided by St Clair and Beale was contained in a letter by Amo Tupuhi (a distant relative of Te Ao Mārama) of Lot 393. Native Land Board minutes also show that neither Kauia or Kahutoroa were in attendance during the alienation process, despite the Board being advised of where they lived. ${ }^{669}$

\footnotetext{
${ }^{667}$, Waikato Maniapoto District Native Land Board, 'Whangamarino Lot 277 (Beale)', Waikato Maniapoto Alienations Minute Book, Maori Land Court, Volume 11, 26 February 1914, pp.20-21. ${ }^{668}$ J. St Clair, "Kua utua mai kia maua e Mrs Beale nga moni e ono te kau pauna ara te moni katoa o te hoko o Rota 277 Parihi o Whangamarino e 30 eka kia Mrs Beale", 5 February 1914, ACIH, series 16036, MA1/1103, ANZ, Auckland.

${ }^{669}$, Waikato Maniapoto District Native Land Board, 'Lot 277 Whangamarino', Waikato Alienation Minute Book, Volume 9, 23 March 1913, p.375; WMDNLB 'Lot 277 Whangamarino', Waikato Alienation Minute Book, Volume 10, 10 June 2013, pp.114-115 and 'Whangamarino Lot 277 (Beale)', Waikato Alienation Minute Book, Volume 11, 26 February 1914, pp.20-21
} 
The minutes of Lot 277's sale and an examination of the Court records suggest that a mutual sale had been effected. In reality however, the sale was processed through the Native Land Board and Native Land Court without consideration or consultation with its owners. This is not an isolated case, and the methodology of utilising Order in Council alienations or national interest alienations point to an underlying fallacy that Māori who received money from land sales were willing sellers. The sale of Lots 277 and $512 \mathrm{E}$ and $\mathrm{F}$ exemplifies how this is false. Of the $1 \%$ in Lot $512 \mathrm{E}$ that agreed to a sale, the other 99\% had not. Similarly with 512F and particularly with Lot 277. However, by virtue of every owner receiving their portion of the sale price, the land has often been construed as being sold by willing sellers.

In returning to Wilson v Herries, the Judge stated that

The inquiry which has to be made by a Māori Land Board or the Native Land Court under section 220 is of an inquisitorial character, and only faintly resembles a preceding inter partes. The Native who has executed an instrument of alienation may, of course, be heard either to object or to consent to its confirmation, but neither his objection nor his consent should have any weight except in so far as it shows that all the conditions exist which under the $2^{\text {nd }}$ subsection entitle the applicant to a confirmation order... ${ }^{670}$

The key component of this quote is the latter part of the second sentence:

but neither his objection nor his consent should have any weight except in so far as it shows that all the conditions exist which under the $2^{\text {nd }}$ subsection entitle the applicant to a confirmation order [emphasis added].

This statement appears to encompass the Court's attitude and legal position on Māori interests. An owner's objection has no weight but an applicant is entitled to a sale or lease. This attitude in the 1960s mirrors Bluwer Lyttons' direction to Gore Browne that

${ }^{670}$ Wilson v Herries, 33 NZLR 417: Court of Appeal, 1913, p.417 
The purchase or cession of land is not only a matter of duty, but will, I am persuaded to be found to be the most consistent with the interests of the colony [emphasis added].

Entitlement, duty and the interests of the colony in the 1860 s, or the national interest in the 1960s became the rationale for alienating Māori land from its owners, regardless of their consent or objections. This was exemplified in Lot 512, which was alienated in the national interest in 1863 and again in the 1960s.

\section{In the national interest}

The alienation of Lot 512 corresponded with the policy of the day and was driven by the international demand for greater food supply. The provisions that should ordinarily have protected Māori owners had counter measures to allow those provisions to be set aside. The notion of protecting Pākehā farmers and their descendants to maintain land or economic units for their own purposes was not extended to their Māori counterparts. Nor were the extensive funding streams and development assistance provided to Pākehā farmers extended to Māori owners.

However, there were objections to the sale of Lots 512E and F and an application to have the land retained in Māori ownership was submitted to the Court. Rawinia Shelford (daughter of Te Ao Mārama) appeared before the Court on 15 June 1961 asking for the land. She argues that

I know I am not in these blocks, but in 512D the adjoining block. We have been asking government to give us this land...[we] feel the whole of Lot 512 should be retained, the Block was vested in Maoris [sic] in substitution for confiscated lands and we think it should not be sold. ${ }^{671}$

The same can be said for the forcible lease of Lots 512A-D blocks through Part XXV alienation in the public interest or Section 33 and 445 regarding agency for the owners.

\footnotetext{
${ }^{671}$ Rawinia Shelford (nee Puru Te Tahua) in M.A Brook, 'Parish of Whangamarino Lot 512E, Parish of Whangmarino Lot $512 \mathrm{~F}$ - Application for confirmation of resolutions to sell to R.J Ellmers', Waikato Alienation Minutes Book, Volume 4, 15 June 1961, pp.263-264.
} 
The national interest is synonymous with the public good and public interest which took precedence over Māori interests. The vision of the nation and the development of that vision negated the development interests of Māori and the cultural importance Māori ascribed to land.

The national interest then, provided the rationale to alienate, by way of sale or lease against the owner's interests and those remuneration rates provided under lease are synonymous with the waste land alienations seen in the 1860 s for 1 penny to $£ 1$ per acre.

Photo 4: Te Ao Mārama whānau: Umawera, Kauia, Kahutoroa, Te Ao Mārama

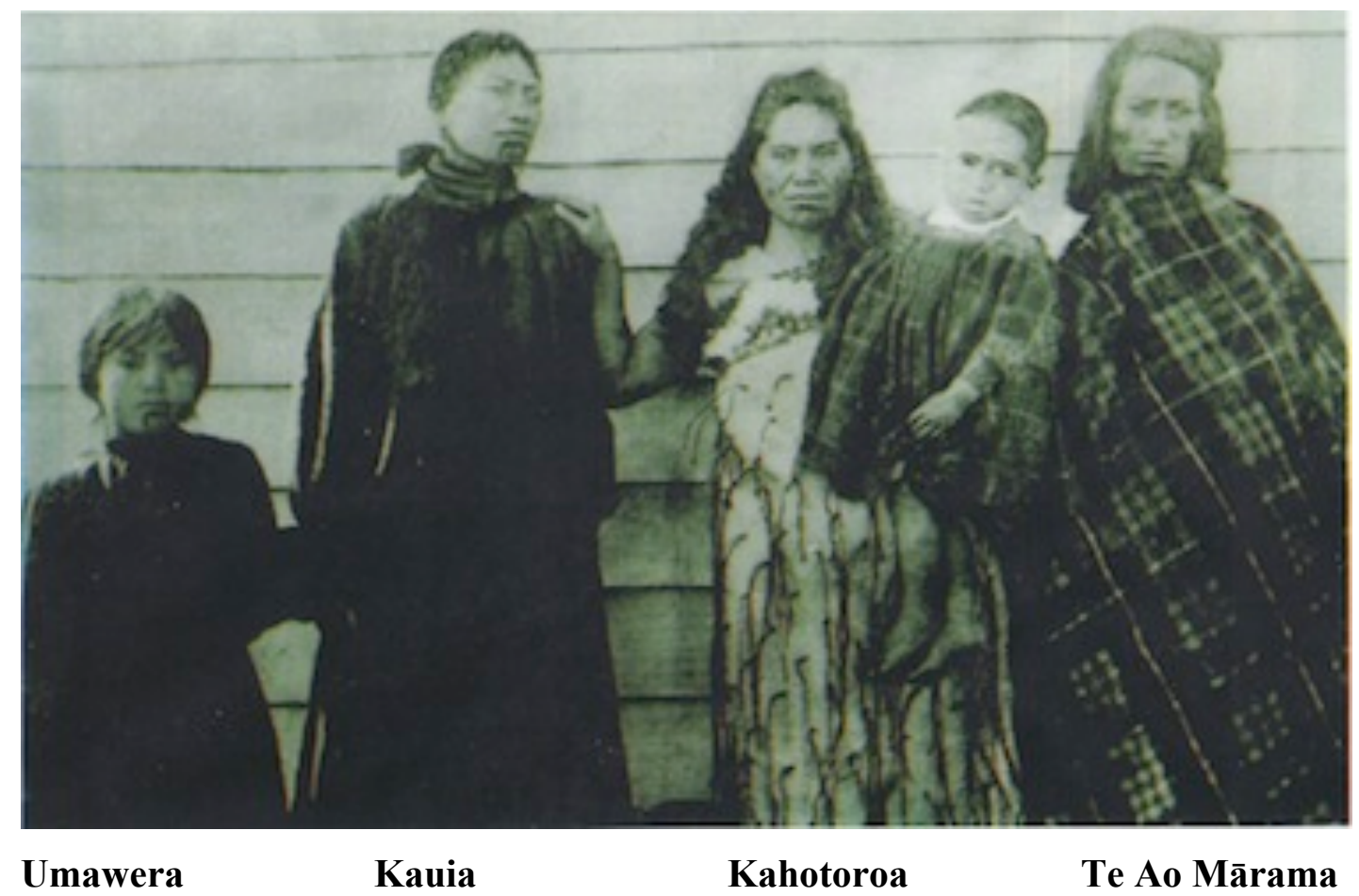

This type of alienation was classified as confiscation then, and I argue, is the same here. The facilitated alienation in the 1960s mirrors the agents' processes and practices as seen in the $1860 \mathrm{~s}$, with one key difference: where in the 1860 s confiscation was preceded by armed conflict, confiscation in the $1960 \mathrm{~s}$ is preceded instead by an enduring conflict of interests.

Now that we know that, so what? In the next chapter I consider what is meant by confiscation outside the nineteenth-century pointing in particular to how confiscation is 
termed today. In determining whether Lot 512 was confiscated, I apply the themes raised in Chapter Three and apply them to Lot 512. I also draw a correlation between the current Te Ture Whenua Māori Act Review and its focus on land production in the national interests before looking at redress options available for owners in Lot 512. 


\section{CHAPTER SIX: MĀ TE MOHIO, KA AHA?}

Kua whakatūria e au tēnei taonga hei āwhina i te pani, $i$ te pouaru, i te rawakore.

He kuaha whānui kua puare ki te puna tangata me te puna kai ${ }^{672}$

I have started this cause to aid the bereaved, the widowed and the destitute. It is a doorway that is open to the bounty of men and the plenty of food.

Government records of the 1800s and early writings show that Ngāti Hine had been living at Pōkaewhenua and the Waikare area through take noho and take tūpuna and had enjoyed a thriving economy in the Parish of Whangamarino. ${ }^{673}$ Both Chapter Three and Chapter Five showed the breadth of economy that was enjoyed by Ngāti Hine before the invasion of Waikato. Following the confiscation of the Pōkaewhenua area, my tūpuna Tamihana Te Ketetauaro and his brother Te Wahienui returned from Rangiriri having fought on different sides. Te Ketetauaro was provided land grants after swearing loyalty to the Crown, while his brother was labelled a rebel and provided similar grants from 1867 onwards. Te Ao Mārama's mother, Kauia, was labelled a rebel as a result of her loyalty to the Kīngitanga and along with her sister Kahutoroa and her daughter Umawera Tamehana, was granted land in a compensation block for rebels at Takapūruharuha (Lot 393). Te Ao Mārama was granted land as a rebel at Pōkaewhenua, (Lot 512) along with her living children and wider relatives.

By the time Te Ao Mārama and her whānau were officially assigned land at Pōkaewhenua, they had gone from controlling a thriving enterprise to subsistence living and by then both her parents and her sister had died. Although they remained on the land, a sour undertone permeated the hapū at Pōkaewhenua. They had been offered back their land as compensation and although they had not been required to swear loyalty to the Crown, there remained a wider suspicion from the iwi that those rebels

\footnotetext{
${ }^{672}$ Handout provided at Te Koroneihana mo Te Kīngi Tuheitia, 2013: Ngā Tongikura o Tawhiao.

${ }^{673}$ Davis, C.O, Maori Momentos; being a series of addresses, presented by the native people, to his excellency Sir George Grey ... with introductory remarks and explanatory notes, to which is added a small collections of laments, \&c., Auckland, Williamson and Wilson, 1855, p.126 and J, St John, $A$ Pakeha rambles through Maori lands, Wellington, Robert Burnett, p.26
} 
who were granted land were originally from other parts of the Waikato. ${ }^{674}$ In addition to this suspicion, the land that had been Ngāti Hine's by take tūpuna was then seen as blood payment from the Crown as compensation. Te Ao Mārama often spoke of the land as moni toto for rebellion during the invasion of Waikato and although rebel grantees were expected to disassociate themselves from the Kīngitanga, Te Ao Mārama and her wider whānau remained loyal to the Kingitanga. ${ }^{675}$

Te Ao Mārama lived and died at Okarea maintaining the history of their whānau occupation there. In 1961, when Ellmers applied to lease and buy parts of Lot 512, Te Ao Mārama's daughter Rawinia Shelford went to the Māori Land Court asking that the block remain physically undivided. Rawinia, at the time, was living in her mother's kauta on Lot $512 \mathrm{C}$, while other owners lived across the block regardless of the boundary lines drawn by the Māori Land Court. Pito whenua were buried where kauta and whare were built and as was seen in Chapter Five, some of Te Ao Mārama's children also lived on Lots 512B and C. Rawinia Shelford explained to the Māori Land Court that the entire block was moni toto and asked that Lots $512 \mathrm{E}$ and $\mathrm{F}$ be sold to the neighbouring Māori owners in Lot 512D. Although the Māori Land Court recorded that Rawinia had no objection to the sale per se, this was inherently incorrect given she had lodged an application to stop the sale to maintain take noho for the whānau already living there.

Te Ao Mārama during her lifetime often utilised the saying: Ma te mohio, ka aha - and now that you know, so what? I argue in this thesis that the facilitated alienation of Lot 512 in the national interest is confiscation.

In this chapter I recall some of the common practices of confiscation as outlined in Chapter Three to determine whether those practices were evident in the alienation of Lot 512. Having done that, I examine the recent Waitangi Tribunal Settlements with a view to compare the confiscation of Lot 512 to the wider confiscation debate across the country to see how it adds to the existing knowledge of confiscation of Māori land. As part of Treaty Settlement terminology, I analyse the term raupatu as it pertains to confiscation to show how it has been limited in its use and by doing so, I argue that there is a practice of renaming common practices of confiscation in the twentieth-

\footnotetext{
${ }^{674}$ Ngawini Puru, Interview, 4 October 2011, Auckland.

${ }^{675}$ Ibid.
} 
century as alienation, and thereby positioning confiscation as a historical issue rather than as a contemporary practice. This relegates the practice of confiscation to the nineteenth-century rather than including and legitimising contemporary confiscation such as Lot 512. Recent Treaty Settlements also remain focused on nineteenth-century confiscation and twentieth-century alienation.

To explore this dichotomy I explore the range of Treaty Settlements undertaken to date and look at how confiscation terminology is utilised. By doing so, I argue that confiscation did not cease in the nineteenth-century and the Government's policy to discontinue further claims against the Crown, diminishes and marginalises Māori, hapū and whānau claims of confiscation in the twentieth century.

Lastly in this chapter, I consider the on-going focus on Māori land productivity and highlight a persistent policy of national interest alienations that can put further Māori owned land in Whangamarino at risk under the recent Te Ture Whenua Māori Review by Te Puni Kokiri.

More importantly this chapter focuses on the outcomes and implications of this thesis for whānau, hapū, iwi and Indigenous peoples generally and how other researchers, whānau or academic, may want to investigate whether national interest alienations were undertaken in their takiwā. In the meantime, the practice by which Lot 512 was alienated by agents of alienation is classified in this thesis as confiscation.

The Māori Land Court, Waikato County Council, Departments of Agriculture, Lands and Survey and Māori Affairs, utilised a range of practices for alienating Lots 512A-F which were collaborative, coordinated, facilitated and deliberate. When owners refused to sell, their land was either passed to the Māori Trustee to sell, or when Māori were encouraged (or more accurately, forced) into lease, the remuneration was commensurate with waste land rates in the 1860s. Furthermore, where owners continued to refuse alienation, County Councils were equipped with Section 108 provisions that allowed charging orders against Māori land and where permissible, to become agents similar to the Māori Trustee and therefore able to alienate Māori from their whenua.

Those few avenues for Māori owners in Whangamarino to access development funds through Māori Affairs were stymied against a criteria provided by Lands and Survey. 
This criteria to promote young, technically trained, scientific farmers over experienced Māori farmers able to farm their own mulitply owned land was biased against its Māori owners. The legislative protections afforded to European farmers and their descendants did not extend to their Māori counterparts. Legislation focused on the promotion of productive farming with financial assistance for Pākehā, whereas other legislation was utilised to marginalise and alienate Waikato Māori from their land. This is both a description of colonisation in the 1840-60s, as well as enduring aspects of colonial practice in the 1960 s.

The majority of the Māori owners in Lot 512 did not want to alienate what little remaining land they possessed, particularly given, for many it was the few acres left after the Waikato invasion. The hapū of Ngāti Hine had gone from 95,776 acres to 6,663 acres for all its hapū members. Many of the 19 blocks set aside for their use had been sold by 1960, and those that remained were multiply owned and utilised by their owners as either papakāinga or small market or subsistence blocks. When Te Ao Mārama died on 5 June 1958 at Pōkaewhenua, her papakāinga on Lot 512 was all that remained of her land in Whangamarino. At the height of her land ownership following compensation awards, Te Ao Mārama received two land blocks from her father (Lots 260 and 261), one from her sister, Te Umawera (Lot 393) and none from her mother (whose land at Lot 277 was taken by an Order in Council alienation). ${ }^{676}$

Te Ao Mārama had also received land from wider hapū members who had died without issue, which was the case with many whānau who had died from influenza in the 1910s and natural death over the years. ${ }^{677}$ Many of the land blocks succeeded by her were either "sold" by owners, alienated by the Māori Trustee, Māori Land Boards or Māori Land Court (Lots 260, 261, 277) or taken under the Public Works Act (Lots 473, 393). Te Ao Mārama suffered with circulatory failure and pulmonary oedema for five days in Okarea before she died. ${ }^{678}$ Waikato Māori like Te Ao Mārama, had maintained a deep distrust of Pākehā doctors and hospitals, and during her lifetime, few health services

\footnotetext{
${ }^{676}$ See succession schedules for the following Block files: Lots 182, 213, 214, 215, 245, 246, 247, 248 , 249, 250, 251, 255, 260, 261, 268, 271, 277, 278, 304, 332a, 335, 393, 442, 471, 473, 512, Maori Land Court office, Hamilton.

${ }^{677}$ Ibid.

${ }^{678}$ Department of Internal Affairs, Death Certificate (extracted from the Maori register), 'Te Aomarama Puru [Registry No. 1958039170]', Register of Births, Deaths and Marriages, Wellington.
} 
were available in the Waerenga area. ${ }^{679}$ Te Ao Mārama had lost her husband, Puru Te Tahua, sixteen years earlier. Puru died of Brights disease or chronic nephritis on 10 March 1942, also at Pōkaewhenua and both were buried at Taupiri. Their children continued the occupation of Pōkaewhenua until they were forcibly evicted from the block in 1969.

The practices of confiscation outlined in Chapter Three provide an ability to test the case study in this thesis against common confiscation practices seen in New Zealand in the nineteenth-century. By doing so, it tests my argument that Lot 512 is confiscation and answers the question I posed at the beginning of this thesis: Is the facilitated alienation of Lot 512 in the national interest, confiscation and if so, what remedy if any is available to its Māori owners?

\section{Confiscation in the Parish of Whangamarino}

The alienation of Lot 512 in the 1960s follows a similar process as those lands alienated in the 1860 s under confiscation. Some of the key practices of confiscation that were evident in the 1860s included legislation, conflict, tenurial revolution, a concept of waste land, settlement and economic expansion, as outlined in Chapter Three. These same practices remained in the 1960s and I will go over each of these in turn.

\section{Legislation}

As was seen in the previous chapter, the legislation utilised to alienate Lot 512 included the Māori Affairs Act 1953 (Part XXIII - to call a meeting and Part XXV, to alienate in the national interests, Section 33 - agency for alienation by the County Council, Section 445 - agency for alienation by the Māori Trustee), the Māori Purposes Act 1931 (Section 34 to alienate due to unproductivity and Section 80 to remove alienation restrictions), the Rating Act (Section 108 - charging orders), and the Noxious Weeds Act (re charges for noxious weeds). All of these Acts contributed to the alienation of Lot 512.

Prior to that alienation, other Acts were also utilised to alienate land in the national interest including the Native Land Act 1907 and the Native Land Adjustment and Amendment Act 1927 which specifically allowed for Lot 512 to be investigated. The

${ }^{679}$ Ngawini Puru, Interview, 4 October 2011, Auckland. 
investigation of Lot 512, as with the other lands listed in Schedule 2 of that Act, departed from the usual rules of title investigation for Māori land. Rather than determining the occupation and use rights as was customary for Māori under take whenua, this Act directed the Judge to proceed as follows:

No claim arising out of the Native customary title of any land prior to its becoming vested in the Crown shall prevail as of right in any proceedings before the Court. The Court, in determining the persons entitled to the lands, or any of them, may proceed upon any principle it deems just, taking into consideration all the circumstances, and may make an order notwithstanding that any person found entitled may not have a strictly legal claim to the land. $^{680}$

The Act also directed the Judge to ignore previous recommendations or reports by the Chief Judge and instead work to "expedite" an outcome. This is a stark departure from previous rules and gave the Judge the authority to rule on the ownership of Lot 512 as he saw fit, regardless of tikanga or take whenua, which was the standing norm elsewhere in the Māori Land Court.

From 1863 to 1969 , a number of changes and amendments were made to Māori land law resulting in 195 legislative Acts affecting Māori land, with 58 Acts between 1907 to 1953 that have some connection with alienation including in the national interest. These Acts conveyed the interests of the government to acquire land, with little thought of the impact on its Māori owners.

\section{Conflict}

Conflict in the context of the 1960s did not require military force and although this was present in the 1860 s, there was also a conflict of interests between the Kingitanga who sought to stop land sales in the Waikato and the colony who desired to access those same lands. This conflict of interests is what precipitated the invasion of Waikato, and this same conflict of interests is also seen in Whangamarino vis a vis the desire by the majority of the Māori land owners at Pōkaewhenua wanting to retain their land. In

${ }^{680}$ Section 39 (4) Native Land Adjustment and Amendment Act 1927. 
contrast, evidence has shown that the Māori Land Court sought to alienate Pōkaewhenua in the national interests.

This conflict becomes polarised when the Māori Land Court presumed to act in the best interests of owners in such a way that it benefitted the few owners who wanted to sell. Rather than subdivide the shares of those wishing to sell, the Māori Land Court ruled that the blocks remain in an unsubdivided state so that the buyer or leasee was better able to utilise the land through farming in the national interests. This was at total odds with the majority of the owners who wished to retain their land. Considering owners such as Te Ao Mārama's whānau were rendered landless in Whangamarino when the sale and lease of Lot 512 was effected, there was strong opposition by the Puru whānau for alienation of the entire block. This was consistent with Tāwhiao's stance in the $1860 \mathrm{~s}$.

In contrast, those owners that did agree to sell were still owners in other land blocks in the Parish including Lot 393 where they were residing. The conflict of interests among the owners themselves mirrored the position of Waikato prior to the invasion of 1863 which saw some Waikato hapū join with the Crown as a means of retaining their land and remaining hapū resisting land sales for that same reason.

By removing the few restrictions afforded to owners to remain on and retain their land, Judges such as Brook, evicted whānau from Pōkaewhenua who were left with no other land in Whangamarino.

The sale of Lots $512 \mathrm{E}$ and $\mathrm{F}$ started a process that effectively alienated the entire block and although owners in Lot 512D tried to stop the sale, Judge Brook argued that the sale was in the owners' best interests and the national interests to sell. Those owners in Lot 512 who resolved in owners' meetings not to sell or lease their land were opposed by the County Council and the Māori Land Court who advocated for alienation. One of the owners in the block, Nepe, with the support of other owners, had the experience to farm the lease and fell within the Māori Affairs criteria to seek funding. In Nepe's best interests, his request to have the lease given to him rather than alienated outside the whānau was declined. 
In Lot 512C, the owners also resolved not to sell or lease their land. Instead, and in the interests of the County Council, a charging order for the recovery of $£ 11$ and an order to have the Council appointed agent for the owners, saw Lot 512C alienated so that the Council could receive their annual rates and the land put into productive use for the national interests. Lot 512B was also alienated. Although the alienation was to one of its Māori owners, a charging order by the Council and an application for alienation by lease or sale was already in place prior to de Thierry purchasing the block. De Thierry leased the block shortly after to a Pākehā farmer and a series of leases have seen the block kept in production ever since.

Those owners evicted from the block by sale or lease were displaced and consequently the majority of the owners migrated into urban centres looking for jobs, housing and a means to create a sustainable livelihood. In reality, overcrowding and poverty resulted with many whānau dependent on welfare or labour intensive employment. This situation has changed little in 2013 and the connectivity by whānau to Pōkaewhenua has lessened with Lot 512A-D remaining in Pākehā leases with little impetus by the owners to manage the land themselves, other than to roll over undervalued leases to local farmers.

There are two distinct sets of interests being evoked in this case: the national interests and the owners' interests. The medium through which these interests were determined was based on priorities set by the government, which was developed into a guiding policy to inform the Māori Land Court's practice: increased productivity in the national interest.

The notion of productivity is subjective and invasive. Subjective in that it is based on a Lockean theory that sees individualistic use of land for the national interest. This national interest has required hapū and whānau like Ngāti Hine to move away from sustaining their own livelihood to feed themselves, to an invasive national focus that sees increased production based on the needs of international markets and national consumption. In Whangamarino, and Pōkaewhenua in particular, this negates the ability for whānau to use their own whenua for their own benefit.

It is important to note here that until her death, Te Ao Mārama lived a subsistence living which revolved around tuna, dried or smoked seafood, kouka, potatoes and other 
vegetables grown on the block's māra. The typical daily meal for Te Ao Mārama was dried tuna that had been hanging for weeks, boiled to soften, complete with maggots and either pūhā, kouka or other green vegetables. Riwai pirau, a delicacy which involved the spoiling of potatoes into a fermented state, being added to the meal, with takakau bread. $^{681}$

Tuna were caught on a daily basis to replenish stocks and then dried and hanged, while bread was made daily from store brought flour. Beef was supplied by whānau members that were working at the abattoirs, and sometimes that meat was stolen as they were unable to afford to purchase it themselves. In many cases however, food was provided as koha by whānau members as was the custom in Ngāti Hine.

From Te Ao Mārama's perspective, the harvesting of tuna from the Pōkaewhenua stream, vegetables from their gardens and kouka from cabbage trees in the bush above their kauta was productive use of the land given it was for their livelihood and it suited the needs of the whānau. This does not include the crops and diary farm run by the whānau members across the block. Within 10 years, Pōkaewhenua was no longer utilised by Te Ao Mārama's whānau or in their best interests. The focus for Pōkaewhenua was nationally focused with little impetus to meet the needs of the land owners.

This conflict of interests, although non-violent, had the same affect as the conflict in the 1860s. On both accounts, their livelihoods taken from them, their whare pulled down, the owners impoverished and the whānau and hapū alienated from their land.

\section{Economic Expansion}

Demands for productivity, international trade to contribute to the Food for Britain campaign and the national economy following World War II, had an impact on Lot 512. Much like the 1860s, autonomy by Māori over their land blocks was absolute until 1863 when war broke out in the Waikato. Following legislative changes and the invasion of Waikato, the land was confiscated including Lot 512 at Pōkaewhenua. Land was used to expand the colony, for settlement and to develop farm Lots which were bought and sold in the Parish to foster industry and drive investment in the area. Colonial expansion into the Parish was deliberate and as was seen in Chapter Five, the war

${ }^{681}$ Ngawini Toka, Inteview, 4 October 2011, Auckland. 
machine had barely passed through Rangiriri before surveyors were marking town and farm Lots for militia, settlers and immigrants.

By the 1950s, Lot 512 had been investigated and was occupied and utilised by its owners in isolation of world events. As the demand for greater productivity for the Food for Britain campaign became apparent, the focus to utilise allegedly underutilised land, particularly Māori land, came into focus. Lot 512 was caught up in the drive for production and as was seen in Chapter Five, the entire block was systematically put through a process to facilitate its alienation.

There is little doubt that world events had an impact on Lot 512 and its requirement to be brought into a particular type of production, given departmental reports, policy and Māori Land Court judicial decisions, supported the alienation for the nation's economic expansion when the confiscation of Lot 512 was undertaken. ${ }^{682}$ In order to do that, further title investigations and tenurial change was undertaken by determining the block's productive use.

\section{Tenurial change - title investigation}

By the time Lot 512 had been alienated in the 1960s, there had been 195 Acts since 1863 that had an impact on Māori land. Māori land legislation had undergone a number of changes that included a focus on productive utilisation of Māori land. On all accounts government advocated a particular type of productivity that was in the national interest while arguing that it was also in the owners' interest. The latter was seldom the case, but in almost every instance, the legislation benefitted the former.

The enactment of the Māori Affairs Act in 1953 caused a major change in Māori land management allowing for the conversion of 'uneconomic' shares, consolidation of Māori shares into a single block, greater alienation provisions at general meetings and alienation in the national interest. Richard Hill argues that "the new revolutionary approach to Māori land title was developed and adopted in the 1953 Māori Affairs Act”. 683 Although conversion and consolidation have dominated academic writing regarding this Act, alienation in the national interest is seldom focused on. These changes

\footnotetext{
${ }^{682}$ See Corbett, 'Annual Report of the Board of Māori Affairs', AJHR, 1951, G-09; Peter Fraser, “'Foreward by Minister of Māori Affairs', AJHR, 31 March 1949; Shephard, 'Annual Report by UnderSecretary', AJHR, 1948.

${ }^{683}$ Hill, Maori and the State, p. 32.
} 
involved little or no consultation with Māori despite the number of avenues for alienation encompassed in that legislation.

Government policy for greater productivity, through stock or dairy farming, fulfilling international demands for food and increased land utilisation meant that Māori land legislation was amended to suit. Targeted funding was also provided to support tenurial changes in the 1860s with the New Zealand Loans Act to facilitate the access to the Waikato, and again in the 1960s with the Marginal Lands Fund. Settlers who were exmilitia were provided 50 acres of land and rations in the 1860 s while in the 1960 s, national interest alienations of Māori land was eligible for funding to develop marginal land provided to farmers. Meanwhile, Ngāti Hine were provided limited opportunities to access development funding and communal attempts to maintain their livelihoods was considered unproductive to the nation.

The alienation of Lot 512 was systemic and worked from the top of the block to its end. Of the 386 acres originally granted to its Māori owners in 1927, 211 acres remain, however none of those acres are either occupied or leased by Māori ${ }^{684}$.

The leases provided on the blocks were paltry in the 1960s with most land leases below $£ 1.20$ per acre, bringing little usable return to its owners. Those benefiting from land were Pākehā farmers utilising land at a profit, the local economy supplying the farmer and the national economy. While this development was occurring, owners such as Raungohi Puru who was raised by Te Ao Mārama and returned there after his marriage to Ngawini, made do with odd farming jobs, mining at the Kimihia and Rotowaro mines or reskilling as a butcher. ${ }^{65}$

Tenurial change through the passing of the Māori Affairs Act 1953 allowed wide powers to alienate Māori land. Any provisions to restrict alienation were removed by sitting Judges under Section 80 of the Māori Purposes Act. Opposition to sale or lease was facilitated through Section 445 of the Māori Affairs Act to allow the Māori Trustee to become an agent for the owners and subsequently alienate the land anyway, or through Section 33 to allow the Council to do the same thing. What little protection remained under the 1927 Act to provide inalienable land to landless Māori was negated

\footnotetext{
${ }^{684}$ There is one unpermitted dwelling which is utilised by a family member, but not lived in full time.

${ }^{685}$ Ngawini Puru, Interview, 4 October 2011, Auckland.
} 
in 1953, leaving no land for the sustenance of the owners in Lot 512. The purpose of that alienation was to allow Pākehā farmers to settle on newly available Māori land.

\section{Settlement}

The settlement in Whangamarino of militia and immigrants took place in the 1860s as well as the 1950s-60s. In the 1860s, settlement occurred after the invasion to remunerate those who fought for the Crown and the introduction of 10,000 immigrants in Waikato. The introduction of those immigrants was undertaken purposefully to outnumber Māori in the region and to occupy those areas that had become available immediately after 1863 .

In the 1950s and 1960s, the Department of Lands and Survey created the Marginal Fund to assist new settlers to develop land as a means of increasing productivity and export products to England. Debate in the House showed strong support to have allegedly underutilised land brought into production through the breaking up of large Pākehā estates and the development of Māori land. The Land Settlement Promotion Act was debated in 1952, a year immediately prior to the Māori Affairs Act 1953, which clearly spelt out the conditions upon which Māori land could be alienated in the national interest.

Some few years later, this criteria was used judiciously in Lot 512. The settlement of Pākehā farmers on Māori land as lessees, or the sale of Māori land to Pākehā settlers who were considered better able to develop the land, can be seen in the returns from the district offices of the Department of Māori Affairs. The Hamilton office showed overwhelmingly that alienation by sale or lease to Pākehā farmers outstripped that of leases to Māori farmers (see Table 4 on page 133).

There was a preferred type of settler for the Waikato area that focused on young farmers with 12 months farm experience and technical training in scientific farming. This preference negated Māori subsistence farming and focused instead on the use of machinery, fertilizers and technology that could maximise production on individually owned Pākehā farms. Although parliamentary debate proffered this method of farming as the only possible way forward, this stance ignored the historic practice by Ngāti Hine of communal agricultural practice that fed Auckland in the nineteenth-century. There was collective amnesia by settlers, the Crown or farmers in general, of Māori 
productivity which did not fit the western mode of productivity, either in the 1860s or the 1960s. The criteria that underpinned western notions of productivity excluded Māori farm or economic experience, while Pākehā farmers were considered as a class of people who could bring the land "into production [which could] be effected only by a sale to a practical young farmer capable of developing them by hard work". ${ }^{686}$ Together with the Department of Lands and Survey's criteria, Māori owners in Lot 512 were not imagined as capable enough to develop their own land.

When Māori were able to meet the criteria however, it was considered to be in their best interests to allow a Pākehā farmer to lease the block (Lots 512C and D) or to buy the block (Lots 512E and F) instead. Judge Brook was explicit when he commented that Lots $512 \mathrm{E}$ and $\mathrm{F}$ "should, in the national interests as well as the interests of the owners" be alienated by first declaring Lot 512 as waste land.

\section{Waste Lands}

Māori land not directly used for cultivation was classified as waste land and wherever possible stripped of native title. ${ }^{687}$ Waste lands in the nineteenth-century were acquired by confiscation or acquisition through Crown purchases of Māori land at minimal prices, with the view to sell them on at a profit to pay for the invasion of Waikato and an expanding economy. Lord Normanby's written instructions to Captain Hobson of 14 August 1839 as mentioned in Chapter 3, argues that :

To the natives and their chiefs much of the land in the country is of no actual use, and in their hands it possesses scarcely an exchangeable value. ${ }^{688}$

The low prices given to Māori for their alleged waste land did not provide Māori with a platform to participate positively in the economy. With little land left in Whangamarino to farm or paltry prices for land, Waikato Māori were left in an uneconomic state of sustainability. This was a deliberate policy. Alan Ward argues that

\footnotetext{
${ }^{686}$ Brook, 'Whangamarino 512E, 512F -sell to R.J Ellmers', pp.284-6.

${ }^{687}$ Hackshaw in Seuffret, 'Colonising concept of the good citizen, p.80.

${ }^{688}$ Normanby to Hobson, 14 August 1839.
} 
added [capital value and security of title through the Torrens system] was denied to Māori, because of the Crown monopoly and the policy of paying minimal prices ${ }^{689}$

Further instructions from Lord John Russell to Governor Hobson on 9 December 1840 also referred to waste land as one of the general practices by which his Governorship should be conducted. Russell pointed to the sale and settlement of waste lands outlining specifically that waste land was to be to used, taxed and failing either, confiscated. ${ }^{690}$ Russell argued that

that all lands held by private persons, and not actually in cultivation, should be subjected to an annual tax, the non-payment of which should be followed by the confiscation and seizure of the land [sic]. ${ }^{691}$

This statement implies that waste or idle land was not tolerated and where possible, put into production, taxed or forcibly removed by confiscation form its owners. Richard Boast argues that according to early Colonists, Māori only had title to the lands they occupied and cultivated, "the rest was 'waste land', which the Crown could immediately grant without further ado once it had acquired sovereignty". 692

In New Zealand, the notion of waste land has been incorporated into statute since the colony was created. In particular however, section 5 of the Waste Land Act 1856 refers to waste lands as follows:

It shall be lawful for the Governor at any time, and from time to time, to except for sale...or to dispose of in such other manner as for the public interest may seem best, such of the said Waste Lands in any of the said Provinces as may be required for the purposes of Military defence, or for the construction of trunk lines of road, or as sites for public buildings for the use of the General Government...Provided always that no lands hereafter acquired from the aboriginal inhabitants, shall be open for sale or disposal, until the Governor shall have notified by Proclamation in the New Zealand

\footnotetext{
${ }^{689}$ Alan Ward, 'National Overview', Volume II, Waitangi Tribunal Rangahaua Whanui Series, Wellington, Waitangi Tribunal, 1997b, p.23.

${ }^{690}$ Russell to Hobson, 'Colonization of New Zealand', p.8.

${ }^{691}$ Russell, 'Charter erecting Colony', p.8

${ }^{692}$ Boast, Buying the Land, p.24.
} 
Government Gazette, that the native title shall have been extinguished over such lands. ${ }^{693}$

The identification of waste land and then confiscation were to be part of the bedrock of the Colony's success. For Russell, "until this is done, there can be no reasonable prospect of the colony making any effectual advance in agriculture, wealth or sound internal policy". ${ }^{694}$ The Charter for erecting the colony of New Zealand, which accompanied Lord Russell's instructions elaborated on waste lands as it pertained to Māori. The Charter allowed for the acquisition and disposal of waste land, in so far as it did not interrupt Māori rights to occupy or enjoy their land, or disrupt the ability for successors to do the same. ${ }^{695}$ The caveat to securing Māori rights to their land was that the land had to be "actually occupied or enjoyed by such natives". ${ }^{696}$ Furthermore, the sales of waste land were a vital revenue earner for the Colony in their first year, behind tax duties (50\%), Vote from the British Parliament (25\%) and sales of waste lands $(25 \%){ }^{697}$

Although guarantees were provided to ensure Māori maintained the lands they were using, the interpretation of what was considered occupied came into question. Ward argues that Lord Russell saw a dim view of Māori rights to their land, limiting Māori rights to "village lands and cultivations", ${ }^{698}$ while the Waitangi Tribunal in their 1987 report on Orakei argues that Hobson was to purchase only those lands that Māori wished to sell and it therefore "acknowledged that the Māori owned all such land" including waste land, whether occupied and cultivated, or not. ${ }^{699}$

As mentioned in Chapter Five, Ngāti Hine used seasonal plantations and mahinga kai sites. Although this seasonal economy was across the rohe and can be argued to be impermanent and therefore unoccupied, as noted previously, Ngāti Hine provided literally tons of goods to the Auckland market, and their economy was reliant on

\footnotetext{
${ }^{693}$ Waste Lands Act 1856.

${ }^{694}$ Russell, 'Charter erecting Colony', p.8.

${ }^{695}$ Ibid.

${ }^{696}$ Ibid, p.32.

${ }^{697}$ Queen Victoria to William Hobson, 'Instructions to our trusty and well-beloved William Hobson, Esq. our Governor and Commander in Chief in and over Our Colony of New Zealand', British Parliamentary Papers, 5 December 1840.

${ }^{698}$ Ward, 'National Overview', p.77.

${ }^{699}$ Waitangi Tribunal, 'Report of the Waitangi Tribunal on the Orakei Claim (Wai-9)', Wellington, Brooker \& Friend Ltd, 1987, p.183. See also Waitangi Tribunal, 'Report of the Waitangi Tribunal on the Muriwhenua Fishing Claim ', Wellington, Waitangi Tribunal, 1988, p.99.
} 
forestry, cultivation, hunting and fishing. These activities were not situated in the immediate surroundings of Pōkaewhenua, but all are within the Ngāti Hine rohe, encompassing the entire Waikare region.

The notion that utilising resources in one corner of the rohe and also its extreme opposite of the rohe is not unlike the practice of farmers in the highlands of the South Island. With a 10,000 acre farm block, not all parts of that farm is utilised at once but stock rotated to avoid pressure on pasture growth. Although, it is not difficult to consider that a Southland farmer can manage a ten thousand acre farm, should Māori do the same with mahinga kai, their economy is seen as transient and impermanent.

A consistent theme of Māori being confined to a limited economic space and imagery in this way was at odds with actual practice. In reality, 'shifting agriculture' as suggested by the Waitangi Tribunal, nullified the idea of Māori having waste lands, as all the resources within their rohe were utilised, depending on the market, season, demand and harvest ability at the time.

The Waitangi Tribunal argued that

It is well to recall that the Māori people by no means relied only on their cultivated land for their food. For them, the distinction between 'cultivated' and 'waste' land in the European sense did not exist. ${ }^{700}$

This aligns with those at Ngāti Hine ki Pōkaewhenua. There was no notion of waste land for Te Ao Mārama or her descendants. ${ }^{701}$ The Tribunal refers to Adams who argued that the Māori "practice of shifting agriculture' included the use of resources on the land, forest, "streams, lakes and swamps" and included a vast range of food items such as aruhe, "rats, birds, eels and fish". ${ }^{702}$ The Tribunal also pointed to Cooke P in the New Zealand Mãori Council case, arguing that there was no such thing as waste land from a Māori point of view whereby

the view generally accepted by historians and lawyers at the present day is that expressed as long ago as 1846 by Sir William Martin, the first Chief

\footnotetext{
${ }^{700}$ Waitangi Tribunal, 'Orakei Report', p.183.

${ }^{701}$ Ngawini Puru, Interview, 3 October 2011, Auckland.

702 Ibid.
} 
Justice. As he put it, before the Treaty of Waitangi the whole of New Zealand "or as much of it as is of any value to man" was divided among the Māori tribes and subtribes. Communal ownership was not confined to areas in actual occupation. ${ }^{703}$

Bearing that in mind, and given that the Instructions to Hobson were to procure those areas of waste land that Māori did not require (of which there were none) for the occupation of settlers, ${ }^{704}$ these acquisitions were nonetheless, not to adversely affect Māori livelihoods. Normanby made this overtly clear by stating that

You will not, for example, purchase from them any territory, the retention of which by them would be essential, or highly conducive, to their own comfort, safety or subsistence. The acquisition of land by the Crown for the future settlement of British subjects must be confined to such districts as the natives can alienate, without distress or serious inconvenience to themselves. To secure the observance of this, - will be one of the first duties of their official protector. ${ }^{705}$

Despite those instructions, the opposite occurred. Māori utilisation was confined to actual occupation and cultivations, while shifting agricultural or mahinga kai practices were ignored as impermanent and any land not physically occupied forcibly alienated or confiscated.

In 1961, Judge Brook declared Lots 512E and F as waste land which was out of step with practice at the time. The term waste land had been in disuse since the consolidation of the Waste Land legislation under the Land Act of 1948. Describing Māori land as unproductive or unutilised was the common practice but even so, declaring Lots $512 \mathrm{E}$ and $\mathrm{F}$ as waste land was inaccurate. It is important to remember that Lot 512 was in actual occupation by its owners and the land utilised for gardens, small dairy farming and tobacco plantations. As with the 1860s, lands utilised by Ngāti Hine were labelled waste land and consequently alienated.

\footnotetext{
${ }^{703}$ Cooke P in Waitangi Tribunal, 'Orakei Report', p.184

${ }^{704}$ Normanby to Hobson, 14 August 1839.

705 Ibid.
} 
These confiscation practices were applied both in the 1860s and 1960s. In both cases, the Māori owners were not considered capable of developing the land in the manner that was supposedly required, despite having successfully utilised the land for their own means in both time periods. Furthermore, although Pākehā farmers sought in the first instance to lease, where this became unfeasible or undesirable, resolutions for lease were changed to have the block sold, as it was more prudent to invest in a block of land that was individually owned and farmed instead of a lease that did not appear to provide long term security of tenure.

Based on all the above factors, the facilitated alienation in the national interests of Pōkaewhenua is confiscation. This type of confiscation has not yet been considered in the Treaty Settlement in Waikato, or for that matter, elsewhere in the country. Most of the Treaty Settlements have focused instead on confiscation that is limited to nineteenth-century alienation of Māori land following either confiscation through the New Zealand Settlement Act, the Public Works Act, or as waste land purchased by the Crown. Confiscation in Treaty Settlements is mostly termed as raupatu but in all cases where confiscation or raupatu is used, these terms are limited to the nineteenth-century.

\section{Raupatu}

Raupatu in its traditional sense is the appropriation of land as a result of conquest or conflict. $^{706}$ As a strict translation, raupatu can be broken into two words, rau and patu, which means the blade of the patu or taken by force or arms. Contemporarily however, raupatu has come to refer to confiscation undertaken in the nineteenth-century under the New Zealand Settlements Act, particularly in the Waikato.

Traditionally the term raupatu was encompassed in the terminology of take whenua which explained in Māori ideology and custom the usage rights Māori had to land.

Take whenua outlined "the types and nature of the rights upon which [Māori] relied, and still rely, in establishing their claims to papatipu land". ${ }^{707}$ The basis upon which these rights are strengthened are occupation and use. The longer the occupation and

\footnotetext{
${ }^{706}$ Maoridictionary.co.nz translates 'raupatu' as conquer, overcome, confiscated or conquest. The definitions are accompanied by examples that infer nineteenth-century taking of land and include land taken both by confiscation or with very small payment.

${ }^{707}$ N. Smith, Native Custom and Law Affecting Native Land, Wellington, The Maori Purposes Fund Board, 1942, p.48.
} 
use, the stronger the rights to the land. Rights did not however confer ownership per se, but rather the right to access, utilise and occupy a given space. ${ }^{708}$

There are four main take regarding land. Take taunaha (naming rights), take tūpuna (by ancestry), take raupatu (by conquest), and take noho (by occupation). Take raupatu was considered a right through conquest wherein land was acquired by the victor as spoils of war. Current High Court Judge Joe Williams (previously Chief Judge of the Māori Land Court) however, argues that take raupatu was a weak form of right and that the pre-eminent right was (and continues to be) take tūpuna or a right through ancestry. ${ }^{709}$

To cement a right, particularly through raupatu, required take noho (occupation). Although local tikanga dictates the length and duration of take noho, the Native Land Court Judges as part of their Court processes, defined specifically what these take were. $^{710}$ For take noho, an absence over three generations extinguished a person's occupational rights to the land. Williams argues that in determining through practice what defined take whenua, "the Māori Land Court simplified tikanga, froze entitlements pursuant to them and then removed them altogether". ${ }^{711}$

By prescribing take whenua, the Native Land Court and later the Māori Land Court effectively rewrote or recodified customary practice and understanding. Although, tikanga evolves and is defined by the kin group or community making each whānau, hapū and iwi tikanga unique to their own rohe, by defining tikanga in a narrow sense, the Judges imposed and limited what whānau, hapū and iwi prescribe as normal within their own kin group. Williams argues that

tikanga divined by a Judge who is not a member of the kin group and handed down from on high to them would be the antithesis of tikanga. ${ }^{712}$

As Judges defined and determined the meaning of whānau, hapū and iwi tikanga, these newly appropriated and defined terms became internalised within Māori conceptual thinking so that contemporarily, raupatu Treaty claims are confined to the nineteenthcentury and whānau and hapū still refer to raupatu in that time frame.

\footnotetext{
${ }^{708}$ Ibid.

${ }^{709}$ Williams, 'A Separate Legal System', pp.3-4.

${ }^{710}$ Williams, 'Maori Land Court', p.4.

${ }^{711}$ Ibid.

${ }^{712}$ Williams, 'Maori Land Court', p.8.
} 
In the Ngāti Awa Settlement Act 2005, the legislation did not provide an interpretation for the term raupatu, but did use 'confiscation' as a translation for raupatu in the Act. The Act provides the timeframe of 1866 as the period at which raupatu occurred and argues that Ngāti Awa enjoyed a buoyant and successful economy prior to 1866. However, the iwi's participation in fighting at Ōrākau and the killing of Reverend Carl Volker and James Fulloon, a Crown official in July 1865, subsequently resulted in a force of 500 Crown soldiers and assistance from other iwi, to attack Ngāti Awa. A proclamation in September 1866 declared 448,000 acres of land eligible for confiscation, with 245,000 actually taken. ${ }^{713}$

Similarly, the Ngāti Ruanui Claims Settlement Act 2003 also used raupatu as a translation for confiscation and refers to the Proclamation of 2 September 1865 that declared all of southern Taranaki a site for European settlement, resulting in the confiscation of most of Ngāti Ruanui's lands. ${ }^{714}$ As another area opposed to land sales, martial law was proclaimed for "Māori opposition to the Crown's attempt to acquire the Pekapeka block of Waitara" and the resulting Taranaki Wars from 1860-1861 and 18631869. ${ }^{715}$ Those who surrendered included 233 Pakakohi men and children who were imprisoned in the South Island and the land in Ngāti Ruanui confiscated and deemed 'an "eligible site", for the purposes of European settlement". 716

In the Ngā Rauru Kiitahi Claims Settlement Act 2005, the term raupatu is also used in Part 1 section 3 (Māori version) and is translated as confiscation in the English translation for those lands taken during the Taranaki wars, the "destruction of their homes, property, cultivations and taonga" as well as "the loss of life during the wars including the lives of unarmed children killed by government militia at Hardley's Woolshed in an unprovoked attack". 717

The Ngāti Mutunga Claims Settlement Act 2006 also refers to raupatu in the Māori text of the legislation and is translated as confiscation. Confiscation in Ngāti Mutunga refers to lands taken under the New Zealand Settlements Act, in particular the Proclamation on 2 September 1865 declared

\footnotetext{
${ }^{713}$ Section 16 of the Preamble in the Ngāti Awa Settlement Act 2005.

${ }^{714}$ Section 6 of the Preamble in the Ngati Ruanui Claims Settment Act 2003.

${ }^{715}$ Section 4 of the Preamble in the Ngati Ruanui Claims Settment Act 2003.

${ }^{716}$ Section 6 of the Preamble in the Ngati Ruanui Claims Settment Act 2003.

${ }^{717}$ Section 9(3) of the Preamble in the Ngā Rauru Kiitahi Claims Settlement Act 2005.
} 
the confiscation district of "Ngātiawa" and designated "Ngātiawa Coast" as an eligible site for settlement. The Ngātiawa Coast eligible site took in the entire rohe of Ngāti Mutunga. All of the land of Ngāti Mutunga was confiscated, despite the declaration that land of "loyal inhabitants" would be taken only where "absolutely necessary for the security of the country". 718

In the Ngāti Tuwharetoa (Bay of Plenty) Claims Settlement Act 2005 raupatu is used in both the Māori and English text to describe confiscation ${ }^{719}$ and identifies the Order in Council of 17 January 1866 which confiscated 87,000 acres of Ngāti Tuwharetoa (Bay of Plenty) land. The raupatu was a result of Ngāti Tuwharetoa (Bay of Plenty) being accused of harbouring the alleged killers of Fullon which resulted in fighting and raids at Pārawa pā within the iwi's boundary. According to the Crown, the Bay of Plenty tribes including Ngāti Tuwharetoa were considered rebels for resisting the Crown's forces who were "sent into the area to arrest those responsible for the deaths of Fulloon and others" ${ }^{720}$ Ngāti Tuwharetoa lost land on the eastern side of the Tarawera River as part of 87,000 acres of confiscated lands taken from other iwi.

In contrast, the Ngati Pahuwera Treaty Claims Settlement Act 2012 does not have a translated version so there is no mention of raupatu, only confiscation. The Ngāti Tama Claims Settlement Act 2003 is also in English so the term raupatu is not utilised here. There are however numerous references to confiscation which are limited to the nineteenth-century.

The Te Roroa Claims Settlement Act 2008 does not contain a translated Preamble also and although there is no mention of either raupatu or confiscation, there is a discussion in the Preamble pertaining to the alienation of their lands from 1875 including the Crown purchase of 87,638 acres in 1876 , leaving less than 13,000 acres remaining (from over 100,000 in total) for the tribe. ${ }^{721}$

The Ngāti Turangitukua Claims Settlement Act 1999 has neither confiscation nor raupatu but unlike previous legislation, this Act focuses instead on the twentieth century and the excessive taking of land to meet "post World War II needs for rapid expansion

\footnotetext{
718 Section 6 of the Preamble in the Ngāti Mutunga Claims Settlement Act 2006.

${ }^{719}$ A Preamble within a Statute aids in the interpretation of any ambiguity within the Statue itself and is not an essential part of an act, and it neither enlarges or confers powers.

${ }^{720}$ Section 17 of the Preamble in the Ngāti Tuwharetoa (Bay of Plenty) Claims Settlement Act, 2005.

${ }^{721}$ Section 30 of the Preamble in the Ngāti Tuwharetoa (Bay of Plenty) Claims Settlement Act, 2005.
} 
of energy resources to meet the growing industrialisation in New Zealand"722 under the Public Works Act 1928 and the Turangi Township Act 1964. The excessive acquisition of land by the Crown to build the Tongariro Power Development exceeded the expectations understood by Ngāti Turangitukua. The terminology used for the taking of land in the Act is "riro". The relevant section of the Preamble reads as follows:

J (iii)

ko te whenua i riro hei tūnga mō te tāone i neke atu te nui i tērā i oatitia e te Karauna ka riro i a ia

the land taken for the township was in excess of the maximum area that the Crown promised it would take.

In the Pouakani Claims Settlement Act 2000, riro was also used to describe the significant areas of land acquired by the Crown to offset survey costs owed in the $1880 \mathrm{~s}$ and 1890 s by Māori and although this was neither illegal or unacceptable, it was considered by both parties that Māori paid a "disproportionate cost for Pākehā settlement" and the Tribunal determined that there remained a "strong sense of grievance and frustration", ${ }^{723}$

As a very recent piece of legislation the Ngāti Porou Claims Settlement Act, 2012 extends raupatu to include processes undertaken through the Native Land Court, where raupatu is translated as "alienation".

In Paragraph 7, the text reads in Māori and English as follows:

C. Paragraph 7

(7) The Crown acknowledges that it promoted legislation that had the effect of allowing the sale of several Ngāti Porou blocks to be completed despite these transactions having failed to comply with all the requirements of the native land laws that governed the alienation of Māori land at the time the transactions were entered into.

\footnotetext{
${ }^{722}$ Section C of the Preamble in the Ngāti Turangitukua Claims Settlement Act 1999.

${ }^{723}$ Section 3 of the Preamble in the Preamble of the Pouakani Claims Settlement Act 2000
} 
(7) E whakaae ana Te Karauna, nana tonu i whakahau ki a waihangātia nga ture ma reira nei e whakamana te hoko o etahi o nga whenua o Ngāti Porou, ahakoa noa kare he mana o enei whakahaere i raro i nga ture whenua Māori, ara te ture whakamana i nga take raupatu i whakahaeretia ana i taua wa.

This extension of raupatu to encompass alienation includes the processes of alienation by the Māori Land Court. Alienation, as defined under the guiding legislation of the Māori Land Court, Te Ture Whenua Māori Act 1993, is stated as follows:

Section 4 (a) includes, subject to paragraph (c),-

(i) every form of disposition of Māori land or of any legal or equitable interest in Māori land, whether divided or undivided; and

(ii) the making or grant of any lease, licence, easement, profit, mortgage, charge, encumbrance, or trust over or in respect of Māori land; and

(iii) any contract or arrangement to dispose of Māori land or of any interest in Māori land; and

(iv) the transfer or variation of a lease or licence, and the variation of the terms of any other disposition of Māori land or of any interest in Māori land; and

(v) a deed of family arrangement relating to succession to Māori land or any interest in Māori land on the death of an owner; and

(vi) an agreement to the taking under the Public Works Act 1981 of Māori land or any interest in Māori land; and

(vii) the granting, renewal, variation, transfer, assignment, or mortgage of a forestry right over Māori land; and

(b) includes, subject to paragraph (c), any disposition of Māori land or of any interest in Māori land which is effected by the Māori Trustee or any other trustee; 
The Ngāti Porou Claims Settlement Act post dates the Ture Whenua Māori Act and suggests either that the Crown had not fully considered the implication of extending raupatu to mean alienation, or did not care whether it did or not. However the implication is significant given the Ture Whenua Act considers alienation in a broad manner to include sale, lease, "every form of disposition of Māori land or of any legal or equitable interest in Māori land, whether divided or undivided", 724

This interpretation of the Ngāti Porou Act supports my assertion that the facilitated alienation of Lot 512 in the national interest is confiscation. The sale of Lots 512B, E and $\mathrm{F}$ aligns with Claims Settlement Acts use of confiscation while the alienation by enduring lease of Lots 512A, C and D is supported by Ngāti Porou's expression of raupatu. Although the latter is a weaker form of confiscation, the owners are nonetheless affected in the same manner as those alienated through sale: by being displaced from their lands and rendered landless by sale, or evicted by lease.

\section{Mā te mohio, ka aha? ${ }^{725}$}

The confiscation of Lot 512 has had a significant impact on the whānau of Ngāti Hine at Pōkaewhenua and its classification as confiscation is used deliberately to convey the enduring practice of some of the effects of confiscation.

It has been argued here that the owners were forcibly put through a process that left no avenue for owners to successfully object or have their interests properly represented. All efforts by the dissenting owners to the sale or lease were ignored. Much like the 1860s when Tāwhiao sought to negotiate with the Crown to dispel any fears of Waikato aggression and to maintain their economic position and livelihoods, Ngāti Hine were also ignored.

Tāwhiao's interests were in conflict with the Crown and Waikato land considered unproductive and wasteful. Demands by settlers to access Waikato land, to expand settlers' economic position and change customary ownership into individual title to better suit European notions of land, led to legislation and an impetus by Parliament to confiscate Waikato land. The taking of that land by force displaced and irrevocably affected Ngāti Hine's economy and livelihood in 1863. The same practices were

\footnotetext{
${ }^{724}$ Section 4(i) of the Te Ture Whenua Māori Act 1993.

725 A kiwaha used by Te Ao Mārama that translates literally as "What will you do, now that you know".
} 
evident in the 1960s: the demand for farm settlement, an expanding economy, tenurial change through the Māori Affairs Act, Land Settlement Promotion Act, Māori Purposes Act and Marginal Lands Act and the declaring of Lot 512 to be waste land. In both the 1860s and the 1960s, Ngāti Hine were displaced and there was irrevocable damage to Ngāti Hine's sustainable economy and livelihood. It seems disingenuous to acknowledge, validate and accept by statute (Waikato Raupatu Claims Settlement Act) that the actions in the nineteenth-century was confiscation but the same actions in the 1960s as alienation, particularly when it was the same action and had the same effect.

Limiting the use of the word 'confiscation' to the nineteenth-century positions confiscation as a historical issue rather than as a contemporary practice. The term alienation appears to have a less severe connotation and can imply that the taking of land is more consensual, as seen in the Te Ture Whenua Māori Act, which suggests that owners are more involved in the making of leases, profit, trusts or licenses over the land. Although in some areas of the country, alienation may have had positive owner participation and agreement, this did not occur in Pōkaewhenua. In fact, there was no ability for the great majority of the owners to have a say. There was also no ability for the shares of those owners that opposed lease or sale to be partitioned out given it was in the Court and applicant's interests to have the blocks remain unchanged. More importantly, Pōkaewhenua was in actual occupation and the land productively utilised when the Court enforced agency through the Māori Trustee to ensure alienation occured.

None of the measures that should have protected the occupation and utilisation of land by owners were exercised and on all accounts, measures were taken to remove barriers to sell or forcibly lease the land, thereby dispossessing the owners of their land, evicting them from their homes and destroying their crops and gardens so that the land could be grazed by stock. The taking of Pōkaewhenua was a fait accompli and was argued as much by Judge Brook when he declared the land waste land and insisted that it be removed from the owners.

It is unclear why the term confiscation shouldn't be used given it fits the description of the practice undertaken in the 1960s and there is also ample evidence that the majority of the owners opposed the sale and lease of Pōkaewhenua. More importantly, it 
accurately reflects what happened in Pōkaewhenua regardless of the current practice of limiting confiscation to the nineteenth-century.

For this same reason, the term raupatu is also not utilised in this thesis to describe what happened in Pōkaewhenua. Raupatu has been similarly limited to the nineteenthcentury and as will be seen in the Waikato Raupatu Claims Settlement Act, the legislation firmly restricts raupatu to the nineteenth-century. As an essentially appropriated customary term with variable uses in legislation, raupatu does not align with the confiscation of land in Pōkaewhenua in the 1960s.

So now that we know that, so what? What action or remedy can be taken? In considering these questions, there are three possible pathways and three implications for Māori owners.

\section{Pathways}

The first pathway is to determine whether a claim by the current owners in the Lot 512 blocks can be taken to the Office of Treaty Settlements. The direct settlements between the Crown and Waikato-Tainui and the inability to submit new Treaty claims, suggests not.

The 1995 and 2010 settlements between the Crown and Waikato-Tainui for raupatu in the 1860s and the Waikato River argues that no person of Waikato-Tainui descent may make a claim within the confiscated area outlined in the 1995 settlement. The settlements with the tribe are considered full and final and cover any claims in the past, present or future.

This has widespread implications. When the 1995 settlement was originally negotiated there was little argument that confiscation in Waikato had occurred in the 1860s. The Waitangi Tribunal process was by-passed in favour of direct negotiations and the 1995 settlement completed. Those negotiations set out the parameters for determining the extent of raupatu and the rules around further claims being brought against the Crown.

For Waikato, Governor George Grey's signing of the New Zealand Settlements Act, confiscating 1,202,172 acres of land in the Waikato and the Suppression of Rebellion Act 1863 which allowed for the use of force against Māori rebels, defines Waikato's 
raupatu experience. In the Heads of Agreement between the Crown and WaikatoTainui, confiscation is specifically referred to as being those lands taken under the New Zealand Settlements Act $1863 .^{726}$ Confiscation is translated as raupatu and the term raupatu is used throughout.

In the Waikato Raupatu Claims Settlement Act, 1995 and the Waikato Tainui Deed of Settlement, the Interpretation section provides a definition of raupatu which is as follows:

\section{Raupatu}

means the confiscation of land in the Waikato claim area, and includes the related invasion, hostilities, war, loss of life, destruction of taonga and property, and consequent suffering, distress, and deprivation, referred to in recitals $\mathrm{E}$ to $\mathrm{G}$ of the Preamble to this act.

The Recitals outlined in $E$ to $G$ of the Preamble provide a summation of the hostilities during the invasion of Waikato $(\mathrm{E})$, the process of the confiscation $(\mathrm{F})$ and the effect of those hostilities and confiscation $(\mathrm{G})$. They read as follows:

(E) In July 1863, after considered preparations by the New Zealand Government, military forces of the Crown unjustly invaded the Waikato south of the Mangatāwhiri river, initiating hostilities against the Kīngitanga and the people. By April 1864, after persistent defence of their lands, Waikato and their allies had fallen back before the larger forces of the Crown and had taken refuge in the King Country:

(F) By Orders in Council under the New Zealand Settlements Act 1863, the Crown unjustly confiscated approximately 1.2 million acres of land from the Tainui iwi in order to punish them and gain control of the land placed by them under the protection of the Kingitanga (although the Crown subsequently paid small amounts of monetary compensation and returned, by Crown grants, but not under customary title and generally not to those who had

\footnotetext{
${ }^{726}$ Signed on 21 December 1994 - see McCan, Whatiwhatihoe, p. 315.
} 
fought for the Kingitanga, approximately one-quarter of the 1and confiscated):

(G) Widespread suffering, distress, and deprivation were caused to the Waikato iwi (both north and south of the Mangatāwhiri river) as a result of the war waged against them, the loss of life, the destruction of their taonga and property, and the confiscations of their lands, and the effects of the Raupatu have lasted for generations:

Section 8 , outlines what is included as part of the Raupatu claim and the relevant subsection for this thesis is outlined in subsection (b) as follows:

\section{Raupatu claims}

(a) Means all claims arising out of, or relating to, the Raupatu or any aspect of the Raupatu; and

(b) Includes all claims arising from the loss of land and of interests in land in the Waikato claim area by confiscation; and

(c) Includes all claims to coal, other minerals, and forests within the Waikato claim area; and

(h) Includes such of the claims made in the Wai 537 claim to the Waitangi Tribunal (being a claim made by Richard Tamihana on behalf of Ngāti Tahinga Iwi and Nga Uri o Tahinga Trust Board) as are based on Raupatu in the Waikato claim area; and

(i) Includes all claims specified in paragraphs (a) to (h) of this definition, whether or not those claims-

(i) Are past, current, or future; or 
(ii) Are founded on rights arising by or in common law (including customary law and aboriginal title), the Treaty of Waitangi, statute, or otherwise; or

(iii) Are made or held by, or on behalf of, all of Waikato or one or more individuals, marae, or hapū; but

(j) Does not include the excluded claims.

This Act argues that all claims of raupatu, past, present or future are covered within the scope of this Act. One of the excluded claims in (j) above refers to the Waikato River which was settled in 2010 in the Waikato-Tainui Raupatu Claims (Waikato River) Settlement Act 2010. Raupatu is also defined in Part 2, section 88 of that Act and the definition is provided in full:

\section{$88 \quad$ Meaning of raupatu claim}

(1) In section 89, raupatu claim has the meaning given to it by subsection (2) to (4).

(2) Raupatu claim means every claim that -

(a) Waikato-Tainui or a representative entity had at any time before the settlement date or at the settlement date or may have at any time after the settlement date, whether or not the claim has arisen or been considered, researched, registered, notified, or made by or on the settlement date; and

(b) is, or founded on, a right arising -

(i) from the Treaty of Waitangi or its principles; or

(ii) under legislation; or

(iii) at common law (including common law relating to aboriginal title or customary law); or 
(iv) from a fiduciary duty; or

(v) in some other way; and

(c) arises from, or relates to, acts or omissions before 21 September $1992-$

(i) by, or on behalf of, the Crown; or

(ii) by or under legislation; and

(d) relates to the Waikato River.

The 2010 Act states categorically that every claim that relates to "acts or omissions before 21 September 1992" by the Crown or under legislation that relates to the River is included in the settlement. Both the 1995 and 2010 Act closes any possibility for a claim by a whānau or hapū to be progressed with the Crown.

The implication that all past, present and future claims are settled appears to close off national interest confiscations in the Waikato despite returned lands granted as compensation for rebels, reserved against alienation, was then systematically confiscated again 100 years later.

Furthermore, section 6AA(1) of the Treaty of Waitangi Act 1975 states that no new claims submitted to the Tribunal after 1 September 2008 by any Māori, that includes a historical Treaty claim will be considered. Section 6(3) does however suggest that if the Tribunal finds that any claim submitted to it under this section is well-founded it may, if it thinks fit having regard to all the circumstances of the case, recommend to the Crown that action be taken to compensate for or remove the prejudice or to prevent other persons from being similarly affected in the future.

Submitting a claim on behalf of Ngāti Hine under Section 6(3) is unrealistic however, and even if it did apply, it is unlikely that Waikato-Tainui would consider a separate claim within their takiwā. This then leads to the second possible pathway - a claim against the tribe. 
Whānau and hapū claims against a tribal structure are not new, but do predominantly relate to representation mandates during settlement negotiations rather than claims for resources as a result of Treaty Settlements. Mandate claims from within WaikatoTainui itself were evident, as were claims from Maungamaunu and the descendants of Tuhuru, ${ }^{727}$ with regard to Ngāi Tahu. Another instance where tribal mandate representation in Treaty negotiations was questioned was in Haronga $v$ Waitangi Tribunal where Mangatu Incorporation disputed Te Manu Whiriwhiri's mandate to address Treaty breaches in relation to the Mangatu State Forest. Although these issues were eventually settled, amicably or otherwise, it does show that whānau and hapū can put their own grievances to their tribal structure. But could this happen in Tainui?

Opposition to the Waikato-Tainui settlements has existed since the original negotiations in the 1990s. Four hapū noted their formal objections which were outlined in tribal documents. Despite this, each hapū has a marae, rangatahi and kaumātua representative in Waikato-Tainui through Te Kauhanganui. The current focus for the Kauhanganui, after recent internal fighting is now focused on economic development and the relativity payment's distribution recently received from the Crown. In December 2013, differing opinions between Tainui Development Group and Arataura have been played out in the newspapers as to who should have control of the $\$ 70$ million and how those funds should be spent. ${ }^{728}$

If there was impetus in the Kauhanganui to consider a hapu claim what might it contain? Firstly it needs to be understood that until 2010, no formal marae at Pōkaewhenua existed. Other marae have instead claimed resources around that area as mana whenua, despite a historic pā and occupation by whānau at Pōkaewhenua.

Claims to the Maramarua forest by other hapū have stated that those whānau at Pōkaewhenua never belonged there, claiming that as a compensation block, those whānau were "planted" there after the war. ${ }^{729}$ This is unsurprising, given current whānau at Pōkaewhenua had only known the history of their occupation there during Te Ao Mārama's later life. It is hoped that this thesis will come some way to rectifying

\footnotetext{
${ }^{727}$ See Report of the Waitangi Tribunal on the Tuhuru Claim, Wai 322, 1993.

${ }^{728} \mathrm{See}$ http://www.nzherald.co.nz/business/news/article.cfm?c id=3\&objectid=10867467 for recent article, downloaded 15 December 2013.

${ }^{729}$ Moko Tauariki, Presentation, 19 October 2013, Rangiriri Pā.
} 
that, but it does not nonetheless eliminate the stigma of rebel Māori being "planted" in the area, or stop other hapu from claiming resource rights in the immediate vicinity.

In any case, Waikato-Tainui received settlements on behalf of the tribe in general and an arrangement between the tribe, the Crown and Hauraki iwi regarding the Maramarua forest. The Settlement saw Waikato-Tainui receive $\$ 13.6$ million while at the same time giving Hauraki ownership of the forest and Waikato-Tainui first right of refusal should they wish to sell. ${ }^{730}$ The Maramarua forest is on Pōkaewhenua's front door step, or more accurately on the other side of the Pōkaewhenua stream, across the road from the marae.

The Maramarua forest pay out, coupled with confiscation of Ngāti Hine land throughout Whangamarino and the centralisation by the tribe of funding from government agencies for other resources such as waterways, lakes and rivers, has left whānau at Pōkaewhenua with little to no direct benefit. This was seen more recently when funding requests of $\$ 60,000$ to complete the marae buildings through the tribal structure in 2010-2013 failed to see a positive outcome, despite the tribe receiving \$13.6 million for a resource in its immediate vicinity: the Maramarua forest.

Instead, Pōkaewhenua marae receives approximately $\$ 8,000$ per annum based on marae registrations. Although tribal members can have whakapapa links with other marae such as Tangoao, Maurea, Waikare to name a few, members may only register at one marae, resulting in a loss of mana whenua and an inability to register to marae they have whakapapa links. In the meantime, the $\$ 8,000$ per annum from the tribe does little to assist whānau, rangatahi or kaumātua development at Pōkaewhenua.

Minutes of a recent Okarea marae $\mathrm{AGM}^{731}$ also show that contestable funding for whānau has been removed and funding to complete marae building projects is in doubt. As at December 2013, the marae has been closed as a result.

There is little likelihood then that the tribe is in a position to consider a claim by a whānau or hapū, given the tribe has yet to provide top up funding for marae development. More importantly, the decision to take a claim to the tribe or the Tribunal

\footnotetext{
${ }^{730}$ Tom Bennion, 'Waitangi Tribunal - The Hauraki Report', Māori Law Review, Wellington, Tom Bennion, Wellington, June 2006, p.5.

${ }^{731}$ Held at Okarea Marae, April 2012.
} 
is a decision that the whānau as a whole has yet to discuss and it is unlikely that any agreement to do so will occur in the next five years as whānau dynamics are a microcosm of the tribe's political environment.

Lastly, the Settlement of Tainui's raupatu claim in 1995 extinguished all hapū claims by having the settlement and return of land under the ownership of the Kingitanga. ${ }^{732}$ Meijl argues that

The removal of hapū rights and hapū control of lands and resources took legal effect through the organisational structure developed to register collective ownership of the assets that were returned to the Waikato tribe and the Kingitanga. ${ }^{733}$

This meant that land and property were registered under Pōtatau Te Wherowhero with members of the Kahui Ariki appointed as custodial trustees so that land could not be sold without $75 \%$ of all beneficiaries and three of the custodial trustees' agreement. ${ }^{734}$

What then is the point of this thesis? In and of itself, the study of Lot 512 provides the missing links in the block's history and the history of Ngāti Hine in the Okarea area. So as an outcome, the third pathway is that nothing is done at all. That the study of the block is enough in itself and provides the outcomes the research participants were seeking from the outset - the history of the block and the whānau's occupation there. As a process of this thesis, presentations to whānau ${ }^{735}$ have resulted in greater whānau identity and connectivity to the whenua at Pōkaewhenua and as a member of the Ngāti Hine hapū. More importantly, there is a greater understanding of the reasons why Lots 512E and F are no longer in Māori ownership and the remaining blocks in perpetual leases. The outcome of this pathway is immediate and stands on its own regardless of the two prior possible pathways.

\section{Implications}

\footnotetext{
${ }^{732}$ Toon Van Meijl, 'Conflicts of redistribution in contemporary Maori Society: Leadership and Tainui Settlement, Journal of the Polynesian Society, 112, p.270.

733 Ibid.

${ }^{734}$ Ibid, p. 271.

${ }^{735}$ Whānau here is limited to those descendants of Raungohi and Ngawini Puru.
} 
The implications of this thesis however are threefold and may have a wider implication for Māori and other Indigenous peoples that have been affected by national interest alienations in their own takiwā.

Firstly, it needs to be said again, that Lot 512 is not an isolated event. National interest alienations occurred in Lots 277, 393 and 473 in the Parish of Whangamarino. District returns from the Department of Māori Affairs office in Hamilton has shown that 1800 acres in 1964 were alienated utilising Part XXV/53. This is significant, more so because little was known about this type of confiscation and further research needs to be done to determine which blocks within these aggregates were taken and whether there are other national interest alienations under parts of the Act regardless of whether Part $\mathrm{XXV}$ was referred to directly or not.

The second implication is that this thesis defines national interest alienations of Māori land as confiscation outside the current limitation of nineteenth-century raupatu. The rationale and practice of confiscation that was present in the $1800 \mathrm{~s}$, I have argued here, was also present in the 1960s. The assertion that national interest alienations are confiscation gives other researchers, whānau, hapū or iwi an ability to consider their own block histories and determine whether 'sales' were actually national interest alienations instead, and therefore confiscation. This may also have implications for other indigenous groups if similar circumstances are also present in their land experiences.

Lastly, should other whānau, hapū or iwi consider similar practices were undertaken in their rohe, than there is the potential to litigate, or possibly re-litigate claims against the Crown, particularly if there were national interest alienations under Part XXV of the Māori Affairs Act 1953 which have not already been included and are outside the strict limitations imposed by the Waikato-Tainui settlement process.

Whether the themes of confiscation can be applied to other parts of the Act is a question for another researcher to consider. In the meantime, the Māori Land Court and Māori Trustee continue to promote increased productivity as the preferred utilisation of Māori land in the national economy's interest.

\section{Current review of Māori land law}


Having considered the nineteenth-century and the 1960s, there is a danger presently to see further confiscation as a result of the Te Ture Whenua Māori Act Review undertaken in 2013. The Review focuses on the same issues discussed here in this thesis: legislative review, unproductive land, Māori ownership, expanding economy and greater farm settlement on Māori land.

One of the key points made during a presentation on the Review ${ }^{736}$ is the ability for the 2.5 million acres of allegedly unproductive Māori land to earn \$8 billion for the national economy. The benefit to the New Zealand economy is promoted as being significant and in the national interest that the 2.5 million acres be productively utilised. $^{737}$ The agencies leading the review are the Māori Trustee and Māori Land Court with peripheral support from Te Puni Kōkiri (Ministry of Māori Development) who is tasked to "realise Māori potential". These three agencies have been the consistent government departments responsible for bringing Māori land into production together with the Ministry of Primary Industries which also released a paper commenting on unproductive Māori land. ${ }^{738}$

The Ministry of Primary Industry, previously the Ministry of Agriculture and Forestry merged with the Ministry of Fisheries, (another key agent of alienation from the 1960s), argues that "there are positive economic consequences associated with facilitating Māori freehold land into the productive sector" and state that:

1. This study explored the potential "size of the prize" in economic terms around MPI applying new governance and management models to facilitate the introduction of currently under-utilised and unproductive freehold Māori land into production.

2. The tangible benefits from introducing more Māori freehold land into production include realising an additional nominal $\$ 8$ billion in gross output

\footnotetext{
73610 May, 2013 at Taupo Lake Event Centre, Taupo.

${ }^{737}$ Te Puni Kokiri, 'Discussion Document: Te Ture Whenua Maori Act, 1993 Review Panel', Wellington, Te Puni Kokiri, March 2013. See also Te Puni Kokiri, 'Ko Nga Tumanako o Nga Tangata Whai Whenua Maori: Owner Aspirations Regarding the Utilisation of Maori Land', Wellington, Te Puni Kokiri, April 2011 and Ministry of Agriculture and Forestry, 'Maori Agribusiness in New Zealand: A Study of the Maori Freehold Land Resource’, March 2011.

${ }^{738}$ Price Waterhouse Coopers, 'Growing the productive base of Māori Freehold Land', Report commissioned by the Ministry of Primary Industries, February 2013.
} 
and $\$ 3.7$ billion in value added above MPI baseline pastoral sector forecasts between 2013 and 2022.

3. The potential barriers to introducing the land include requirements for additional investment in the land of just under $\$ 3$ billion and time required to bring the land into production - the benefits are tangible but likely to be incremental. $^{739}$

This report then fed into the discussion document for the Te Ture Whenua Māori Review. The core principles that were set out for the panel included empowering “engaged owners", fit for purpose legislation, best practice and accountability. Engaged owners were defined as those "who have actively demonstrated their commitment to their ownership interest" and therefore better able to make decisions about land utilisation. Based on those principles, the key propositions the Panel set out in their document were:

Proposition 1: Utilisation of Māori land should be able to be determined by a majority of engaged owners

An engaged owner is defined as an owner who has actively demonstrated their commitment to their ownership interest by exercising a vote either in person or by proxy or nominee. Engaged owners should be able to make decisions (excluding sale or other permanent disposition) without the need for endorsement by the Māori Land Court.

\section{Proposition 2: All Māori land should be capable of utilisation and effective administration}

Where owners are either not engaged or are unable to be located, an external manager or administrator may be appointed to manage under-utilised Māori land. The Māori Land Court should have a role in approving the appointment and retaining oversight of external administrators.

Proposition 3: Māori land should have effective, fit for purpose, governance

${ }^{739}$ Ibid, p.5. 
The duties and obligations of trustees and other governance bodies who administer or manage Māori land should be aligned with the laws that apply to general land and corporate bodies. There should be greater consistency in the rules and processes associated with various types of governance structures.

\section{Proposition 4: There should be an enabling institutional framework to support owners of Māori land to make decisions and resolve any disputes}

Disputes relating to Māori land should be referred to mediation in the first instance. Where the dispute remains unresolved following mediation, it may be determined by the Māori Land Court.

\section{Proposition 5: Excessive fragmentation of Māori land should be discouraged.}

Succession to Māori land should be simplified. A register should be maintained to record the names and whakapapa of all interests in Māori land, regardless of size. ${ }^{740}$

In essence the drive is for greater utilisation and productivity of land, overseen by a strong governance structure. Where land remained unproductive and owners ineffective, "action should be taken to appoint an external manager to administer and develop the land block on behalf of the disengaged owners". ${ }^{741}$ External managers can include the Māori Trustee or other Post Settlement Governance Entities, but emphasis is placed on the Māori Trustee as the preferred agent.

This Review has the same content and context of the 1960s national interest alienations - utilise land or as argued here, have it confiscated. The agents to facilitate those alienations are the same: the Māori Land Court, Māori Trustee and the renamed Department of Agriculture. The proposed outcomes are also the same - the expansion of the economy by settlement of productive farms on Māori land. Should these propositions be carried through in the current form, then I would also argue that it falls

\footnotetext{
${ }^{740}$ Te Puni Kokiri, 'Discussion Document', p.3.

${ }^{741}$ Ibid, p.23.
} 
within the definition of confiscation given its close similarity to the confiscation of Pōkaewhenua. 


\section{CHAPTER 7: MĀ TE MŌHIO, KA EA: CONCLUSION}

Taku tono ki a koe Te Paraehe, waihōtia mai māku anō hei whakahaere aku whenua, me taku iwi.

I ask you to leave me the administration of my own land, and also the control of my own people. ${ }^{742}$

In 1882, Tâwhiao tried on a number of occasions to persuade the then Native Minister, Bryce to support Waikato land polices that were focused on retaining land, economic development and providing sustenance according to their traditions and culture. ${ }^{743}$ On all accounts Bryce refused and the continued policy of land alienation across the country and land reservations for rebel Māori was maintained.

One of Tāwhiao's challenges at that time was persuading his followers not to progress claims through the Native Land Court, and in doing so validating the processes put in place to govern and administrate Māori land. ${ }^{744}$ However, as land grants became individualised and limited to ten owners (or trustees in some cases), many Māori flocked to the Native Land Court to secure land wherever possible. For Ngāti Hine, this process had already been determined through land grants provided by the Compensation and Native Land Courts. Those lands set aside for rebel or landless Māori included two specific reservations set aside for their use and a small number of other land blocks for those fortunate enough to be awarded compensation.

A key component in the granting of land for Waikato Māori was the condition that grantees disassociate themselves from the Kīngitanga movement and remain apart from the movement. This did not happen in Pōkaewhenua, or elsewhere in the Parish. ${ }^{745}$ Ngāti Hine were staunch supporters of the Kīngitanga and both they and Ngāti Naho played a large role at Rangiriri. Although the condition to swear fealty to the Crown was a necessity for Waikato Māori who were granted land in the nineteenth-century, there is little likelihood this requirement was actually followed.

\footnotetext{
${ }^{742}$ Turongo House, Tāwhiao, p.149

${ }^{743}$ Ibid.

${ }^{744}$ Ibid, p. 148.

${ }^{745}$ See McCan, Whatiwhatihoe, p.61.
} 
By the time Te Ao Mārama was granted land at Pōkaewhenua in 1927, she was no longer required to swear fealty and had that been a necessity, she would have signed the paper but ignored its content. Te Ao Mārama ensured her descendants maintained support and loyalty to the Kinngitanga which continues to today. Te Ao Mārama is also carved in a wharenui at Maurea and a wharekai at Pōkaewhenua is also named after her. Both Maurea and Okarea marae are staunch supporters of the Kingitanga and an enduring practice of service is expected of her descendants.

The second requirement for land grants was that the land remain occupied by its owners. Te Ao Mārama and her whānau maintained ongoing occupation at Pōkaewhenua until their eviction in 1969. Whānau continuously advocated for the land to remain in their ownership, and it was those same Māori owners whose inalienable rights were alienated by a Judge who sought to have the land productively utilised. All protective measures put in place to assist landless rebel Māori, were removed. The rationale for removing those protective measures was so that the nation could benefit, when it had already done so in 1863 when it confiscated the land for the first time, and again when it confiscated it 100 years later.

This thesis argued that the facilitated alienation of Pōkaewhenua - Lot 512 in the national interest, by virtue of the manner in which it was alienated, is confiscation. I compared the confiscation practices of the 1860s and the 1960s and found the agencies involved, the purpose for land acquisition and the practices of alienation were similar on all accounts. By analysing those practices, it became clear that the key government agencies involved intersected through their membership in the Board of the Department of Māori Affairs in the 1960s. The Influencing Alienation figure on page 122 bears this fact out and all those agents of alienation played a vital role in confiscating Māori land in the 1860s and the 1960s.

A key component of confiscation in the 1860s was the ability for the Māori Land Court to change the rules to suit the national interest and policy of the day. Although O'Malley argued that the Native Land Court ceased to be considered a land stealing court in 1909, this thesis argued that the confiscation practices continued well into the 1960s. 
Conditions stipulated by Judges could be changed or interpreted depending on guiding policy, evolving court rules and as seen recently with the Ture Whenua Māori Review, based on other government departmental reports. Māori land productivity has come under scrutiny since the colony was formed in 1856. No other issue has affected the Parish of Whangamarino nearly as much as the productivity of its land. It was this "productivity" that created settler jealousy in the 1850s, underpinned the basis for determining waste land, drove legislative changes and then used as a means to evict or sell out land from its Māori owners.

John Locke's theory of productivity influenced colonial policy and Locke's underlying philosophy regarding productivity has endured legislatively, in government policy and in the administrative practice of the Māori Land Court. The government agency tasked to advocate for Māori in the 1960s (the Department of Māori Affairs) and realising Māori potential in 2013 (Te Puni Kōkiri - Ministry of Māori Development) appears more concerned with the productivity of Māori land, rather than the productivity and sustenance of the Māori owners.

Māori owners do not share the indefeasible rights of non-Māori owners. Where land is considered unproductive, that land can be confiscated. Where land is occupied and sustainably used, Lot 512 shows that land can still be confiscated. On both accounts confiscation is undertaken to support the expanding economy and the national interests. The interests of Māori owners as seen in this thesis are secondary, changeable depending on government policy and in practice, defined by the national interest. As seen in Pōkaewhenua, the interests of the majority of the owners was to remain on the land and continue to productively use it according to their culture and traditions, whether sustainably or for trade. This was not in the national interest and the Judge made it clear that the owners occupying and productively using their land were of little or no consequence by ignoring attempts by the owners to buy Lots $512 \mathrm{E}$ and $\mathrm{F}$, ignoring attempts by owners in Lot 512D to farm their own land and consequently selling the former and evicting the latter including those on Lots 512A-C.

Te Ao Mārama's children and grandchildren living on the block were forcibly removed. The Judge declared their land waste land and as a consequence, their homes were pulled down and their gardens, plantations and milking sheds burnt or ploughed up and turned 
in to pasture. This is no different from the 1860 s when militia razed productive gardens, orchards, plantations and destroyed flour mills, waka, buildings, whare and villages. The burning of whare and ploughing up of gardens and plantations was not limited to the nineteenth-century. This activity, sanctioned by the Māori Land Court, occurred 44 years ago and as argued by Judge Carter in 1995, there was an expectation that dwellings and gardens were to be removed. It is unlikely the owners shared this expectation.

Crown grants through compensation allowed a right of ownership as long as it complied with conditions laid out by the Māori Land Court. General land owned by non-Māori did not have these same conditions. Pākehā land rights were protected and considered an indefeasible right where owners could do as they pleased with the land. During an Interdepartmental Committee Inquiry in 1960, it was found that non-Māori owned land was less productive than Māori owned land, but in the course of this thesis, no examples were found of national interest alienations applying to General land owned by Pākehā. It should be pointed out again that both Māori and General land owned by Māori are administered by the Māori Land Court.

The rights provided to Ngāti Hine at Pōkaewhenua was that their occupational rights were protected. The Native Land Court had argued that a person's take noho could only be extinguished where the owners were absent over three generations, or under the Waikato Confiscated Lands Act, that an owner had failed to occupy their land grant for two continuous years. ${ }^{746}$ Neither of these applied to Pōkaewhenua.

Additionally, Māori interests were also overseen by adjudicators who made it clear in cases such as Wilson $v$ Herries that there was no obligation on a Judge to either consider or determine owners' interests, particularly where these contravened the national interest. Although provisions to protect owners' interests were outlined in legislation (see Chapter Five) and appeared to ensure that the interests of Māori owners were protected, these protections were only upheld were they did not conflict with the wider public or national interests of the day.

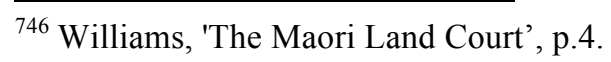


In contrast the national interest has evolved from and continues to maintain colonial practices and values. New Zealand's colonial experience and national identity was derived from British settlers who having developed a colony and effected the establishment of a settler government, then determined what was in the best interests of themselves. Having defined their common aims and interests, the government then set about developing legislation and policies to support those interests.

In a broader context the expression of national interests were framed by the government. The ability by colonial and then national governments to imagine and define their interests, furthered by their ability to implement and drive their interests, gave those in power the impetus to push forward their own objectives. As was seen in Chapters Three, Four and Five, Waikato Māori had little say or inclusion in the development of colonial policy and by the twentieth century avenues to influence policy had barely increased. The national interest did not include Waikato previously, nor does it adequately allow for them today.

Of the 95,775 acres in the Parish, 6,663 acres were returned to Waikato Māori through compensation grants. There are currently 1503 acres remaining throughout the Parish in Māori ownership, which is less than 4\% of the Parish land mass. In Lot 512, 214 acres remain, all of which is in lease except 2.5 acres that is utilised for a marae and urupa. Of the 386 acres originally granted to landless Māori, less than $0.7 \%$ is in actual use by the descendants of the original owners but none of it in actual occupation by the owners. The remaining 211.5 acres require permission from the farmers to access or cross the land.

Although the Lot 512 blocks are under lease and administered under Ahu Whenua or Family Trusts, on Lot 512D, the largest remaining block there is no impetus to allow whānau members to farm the block in the owners' interest, as it is assumed by whānau that if they don't use the land properly then the land would be taken from the owners again. $^{747}$

${ }^{747}$ Ngawini Puru, Interview, 3 October 2011, Auckland. 
As a result of this thesis, it is clear that Lot 512 was confiscated, the manner in which that confiscation took place, and the impact this still has on its owners. For Lot 512 whānau, there is a mistaken assumption that only Pākehā farmers can utilise the land. More insidiously, it also became clear that owners in Lot 512 feel they should be grateful that an annual lease payment is even paid because for many the fear remains in the owners' minds that the Māori Land Court could take the land without any payment. $^{748}$

In the previous chapter, the question posed was "mā te mohio, ka aha - so now that you know so what?". Of the pathways and implications outlined, the likely outcome of this thesis is that nothing is done with regarding to claims against the Crown and the tribe. That option is closed, both through the government process and more importantly because the tribe has eliminated any ability by a tribal member to seek redress other than through the tribal structure. The loss of 386 acres by sale and lease is inconsequential in comparison to the relativity payment of $\$ 70,000,000$ recently received by the tribe. The tribe would be lucky to get a few hundred thousand in compensation for Lot 512 from the government and it is already clear that the whānau has been incapable of securing $\$ 60,000$ to complete the marae.

The benefit of this thesis is defined by the whānau who requested it to be done. As a historical record of Pōkaewhenua, its confiscation, compensation and re-confiscation, provides a history of the land block, its occupants and the hapū of Ngāti Hine at Pōkaewhenua. This history has not been recorded elsewhere and is already been utilised as a means to wānanga with the wider whānau.

The implications for the field of Māori Studies is that the investigation of Lot 512 provides another perspective of confiscation, its continued practice in the twentieth century and the reason why the utilisation of this term is important. This thesis expands confiscation to allow for alienation by sale and lease in the national interest and breaks away from the limitation of the nineteenth-century. This thesis also contributes to Māori Studies through the analysis of other parts of the Māori Affairs Act 1953 as it pertains to national interest alienations under Part XXV. As a wider implication for

$\overline{748}$ Okarea Whanau Trust meeting, 3 April 2011, Okarea. 
Māori land, it challenges researchers to look more closely at Māori land sales in the 1950-1960s, the manner in which those sales and leases were undertaken and to question national interest arguments for alienating further Māori land.

The implications recommended are left to researchers seeking further answers to land sales, alienation and confiscation in the twentieth, and new millennium. It is doubtful whether national interest alienations will cease given the continued drive by Te Puni Kōkiri and Ministry of Primary Industries’ focus on Māori land productivity.

It was Tāwhiao's hope that one day, the government would leave him and his people to administer their own land, their economic development and themselves according to the culture and traditions of his people. Tāwhiao asked the Native Minister at the time, Bryce:

taku tono ki a koe Te Paraehe, waihotia mai maku ano hei whakahaere aku whenua me taku iwi - I ask you to leave me the administration of my own land, and also the control of my old people.

In 1882, that request was turned down. In 2013, one hundred and thirty one years later, the government is still looking at ways to have Māori land utilised in the national interest. National interest alienations of Māori land are a type of confiscation and the case study of Lot 512 shows the manner in which that confiscation took place.

Now that Te Ao Mārama's question: 'mā te mohio, ka aha?' has been answered above, the reply by virtue of this thesis, is 'mā te mohio, ka ea' - 'now that we know, it is finished'. 


\section{BIBLIOGRAPHY}

Act of Parliament - England

Treason Act 1351

Act of Parliament - Australia

New South Wales Act 1841

Acts of Parliament - New Zealand

Affliate Te Arawa Iwi and Hapu Claims Settlement Act 2008

Confiscated Lands Act 1867

Confiscated Lands Act 1876

Land Act 1948

Land Settlement Promotion Act 1952

Maori Affairs Act 1953

Māori Affairs Amendment Act 1967

Māori Purposes Act 1931

Māori Purposes Act 1943

Maori Purposes Act 1950

Māori Reserved Land Act 1955

Māori Vested Lands Administration Act 1954

Marginal Lands Act 1950

Native Lands Act 1865

Native Lands Act 1862

Native Land Act 1931

Native Land Amendment Act 1936

Native Land Amendment and Native Land Claims Adjustment Act 1927

Native Land Settlement Act, 1907

Native Purpose Act 1931

Native Reserves Act' 1882

Native Trustee Act 1920,

New Zealand Loans Act 1863

New Zealand Settlements Act 1863 
New Zealand Settlements Amendment and Continuance Act 1865

Ngai Tahu Claims Settlement Act 1998

Ngati Apa (North Island) Claims Settlement Act 2010

Ngati Awa Claims Settlements Act 2005

Ngati Manawa Claims Settlement Act 2012

Ngati Mutunga Claims Settlement Act 2006

Ngati Pahauwera Treaty Claims Settlement Act 2012

Ngati Ruanui Claims Settlement Act 2003

Ngati Tama Claims Settlement Act 2003

Ngati Turangitukua Claims Settlement Act 1999

Ngati Tuwharetoa (Bay of Plenty) Claims Settlement Act 2005

Ngati Whare Claims Settlement Act 2012

Noxious Weeds Act 1950

Port Nicholson Block (Taranaki Whanui ki Te Upoko o Te Ika) Claims Settlement Act 2009

Pouakani Claims Settlement Act 2000

Rating Act 1925

Suppression of Rebellion Act 1863

Te Roroa Claims Settlement Act 2008

Te Ture Whenua Māori Act 1993

Te Uri o Hau Claims Settlement Act 2002

The Ngati Porou Claims Settlement Act 2012

The Ngaa Rauru Kiitahi Claims Settlement Act 2005

Treaty of Waitangi Act 1975

Waikato Confiscated Lands Act 1880

Waikato Raupatu Claims Settlement Act 1995

Waikato-Tainui Raupatu Claims (Waikato River) Settlement Act 2010

Waste Lands Act 1856

\section{New Zealand Parliamentary Debates}

'Address in Reply', 1 July 1952.

'Want of Confidence', 3 July 1952.

Cooksley, 'Imprest Supply Bill, Vol 299, 10 April 1953.

Corbett, Ernest, 'Māori Purposes Bill’, 29 November 1950. 
Fitzgerald, James 'Waste Lands Bill, 30 June 1854.

Fox, William (1861 to 1863) Legislative Council and House of Representatives.

Gore Browne, Thomas 'Governor's Speech' in the Legislative Council, 27 May 1854

Nash, Walter, 'Māori Affairs Bill', 18 November 1953.

Paikea, Tapihana ,'Māori Affairs Bill’, 18 November 1953.

Tirikatene, E.T, 'Imprest Supply Bill’, 10 April, 1953.

Ward, Joseph, ‘Supply’, 10 November 1909.

\section{British Parlimentary Debates}

Lord John Russell to Governor Hobson, 'Charter for erecting the Colony of New Zealand, and for creating and establishing a Legislative Council and an Executive Council, and for granting certain powers and authorities to the Governor for the time being of the said Colony', Correspondence Respecting the Colonization of New Zealand, British Parlimentary Papers, No.17, Enclosure 1, 9 December 1840, p.32 Downloaded from http://digital.liby.waikato.ac.nz on 30/06/2013.

\section{Appendices to the Journals of the House of Representatives}

Browne, B (1860) 'Letter to Duke of Newcastle', Session I, E-06A, 20 September 1859

Bryce, John, (1884) 'Memorandum by the Native Minister on the Opening of Kawhia Harbour, and on the recent establishment of a Constabulary post in that Locality', Session 1, G-01, 16 October 1883.

Cameron, D.A, (1863) 'Lieut-General Cameron, C.B., to his Excellency the Governor', Further Papers relative to the Native Insurrection, Session I, E-05a, 24 November 1863.

Carrington, F.A (1859) Letter to Governor Gore Browne, E-03E, 21 March 1859. 
Corbett, Ernest, (1951) Annual Report of the Board of Māori Affairs and of the UnderSecretary, Department of Māori Affairs, for the year ended 31 March, 1951', G-09, 1951.

Domett, Alfred, (1863) 'Memorandum for the Governor', Colonial Responsibility in Native Affairs, Session I, E-07, 24 June 1863.

(1863) Memorandum on roads and military settlements in the Northern Island of New Zealand, Session I, A-08a, 5 October 1863.

Fenton, F (1860) 'Journal of F.D Fenton, Resident Magistrate of Waikato, Commencing July 12, 1857: Enclosure in No. 3', Further Papers relative to Native Affairs', Session I, E-01c, 5 October 1857.

(1866) 'Papers Relating to the Sitting of Compensation Court at New Plymouth', Further Papers Relative to Native Affairs, Session I, A-13, 12 July 1866.

Fox, William (1864) to Governor Grey, 'Observations on the Proposal to take Native lands under an Act of the Assembly', Papers Relative to Confiscation of Native Lands, Session I, E-02b, 31 December 1863.

(1864) to Aborigines Protection Society, Memorandum by Ministers in Reply to Aborigines Protection Society, Enclosed in No.4, Papers relative to Native Policy including.... Military Settlements, Session I, E-02, 5 May 1864.

(1864) to the Lord Bishop William Waiapu, 'Enclosure 3, No. 1', Papers relative to Native Affairs, Session I, 4 July 1864.

Fraser, Peter, (1949) 'Foreward by Minister of Māori Affairs', Annual Report of the Board of Māori Affairs and the Under-Secretary, Department of Māori Affairs for the year ended 31 March 1949, G-09, 31 March 1949.

Gilfedder, M and H Haszard (1914) to A. de Brito Savile, 'Commission of Inquiry in Regard to the Existing Reserves for Landless Natives in the South Island and in the 
Waikato-Maniapoto Native Land Court District, and as to the Disposition thereof', Session 1, G-02, 31 August 1914.

Gore-Browne, T (1860) to Sir E B Lytton, 'Further papers relative to Native Affairs', AJHR, Session I, E-01, 29 September 1858.

Grey, George, (1864) 'Memorandum by the Governor as to proposed Terms to Rebel Natives', Papers relative to Native Affairs, Session I, E-02, 3 May 1864.

(1864) 'Memorandum by Governor', Papers relative to Native Affairs, Session I, E-02, 7 May 1864.

- (1864) 'Enclosure 2 to No.11', Papers relative to Native Affairs, Session I, E-02, 28 May 1864.

Heaphy, Charles, (1864) Memorandum by Charles Heaphy, CE. on the Native question, Session I, E-09, 17 November 1961.

Lands and Survey, Department of (1958) 'Introduction', Session I, C-01

MacKay, John (1900) 'Landless Māoris in the Waikato, Thames Valley, and Tauranga Districts: Who lost their land by Confiscation', Session I, G-01, 22 May 1900.

Martin, William (1861) 'Appendix A: Native Tenure: Extracts from Opinions of Various Authorities', Session I, E-01, 4 December 1860.

(1864) to William Fox, 'Observations on the Proposal to take Native lands under an Act of the Assembly', Papers Relative to Confiscation of Native Lands, Session I. E-02b, 16 November 1863.

Matewha, Piripi (1863) 'Piripi Matewha to his Excellency the Governor, Papers relative to the Native meeting at Peria in October 1862, Session I, E-12, 3 November 1862. 
McGillivary, M, (1871) Return of the Crown Lands in each Province showing the extent acquired by Confiscation, Session I, C-04a, 17 August 1871.

McGregor, R.H, (1863) 'The Resident Magistrate, Raglan, to the Honourable the Native Minister', Papers relative to the Native meeting at Peria in October 1862, Session I, E12, 29 October 1862.

Native Land Laws, Commission of Enquiry (1891) Commission appointed to enquire into the subject of the Native Land Laws, Session II, G-01, 11 February 1891.

Native Lands, Commission on (1909) 'Native Lands and Native Land Tenure: Interim Report of Native Land Commission, on Native lands in Manukau, Waikato, Thames and Ohinemuri Counties', Session I, G-01a, 16 December 1908.

Nero, Hetaraka, (1863) 'Hetaraka Nero to Mr Halse', Papers relative to the Native meeting at Peria in October 1862, Session I, E-12, 5 November 1862.

Ngata, A. (1932) 'Native-Land Development: Statement of the Hon. Apriana T. Ngata, Native Minister', Session I-II, G-10.

Selwyn, Bishop (1863) 'Report on the meeting at Peria in October 1862, by Bishop Selwyn', Papers relative to the Native meeting at Peria in October 1862, Session I, I-12, 23 October 1862.

Shephard, G.P, (1948) 'Annual Report by Under-Secretary for the year ended $31^{\text {st }}$ March, 1948', Department of Māori Affairs, Session I, G-09, 21 July 1948.

Smith, Thos (1863) to Native Minister, 'The Civil Commissioner to the Honourable Native Minister', Papers relative to the Native Meeting at Peria, Session I, E-12, 21 November 1863.

St John, J. H, (1873) 'Report on Confiscated Lands' in 'Further Papers Relative to Confiscated Lands', Session 1, C-04b, 12 August 1873. 
Stout, Robert (1907) and Apirana Ngata, 'Native Lands and Native-Land Tenure (Interim report of the Commission appointed to inquire into the Question of )', Session 1, G-01, 21 January 1907.

Survey, Department of Lands and (1958) Report of the Department of Lands and Survey for the year ended, C-01, 31 March 1958.

Tauranga, Heta (1863) 'Heta Tauranga to the Honourable the Native Minister', Papers relative to the Native meeting at Peria in October 1862, Session I, E-12, 1 November 1862.

Whitaker, Frederick, (1864) 'Memorandum by Ministers as to proposed Terms to Rebel Natives', Papers relative to Native Affairs, Session I, E-02, 3 May 1864.

(1864) 'Memorandum by Ministers', Papers relative to Native Affairs, Session I, E-02, 25 June 1864.

Wilkinson, G.T (1881) 'Reports from Officers in Native Districts [In continuation of G.-4, 1880]', Session I, G-08, 28 May 1881.

(1882) 'Reports from Officers in Native Districts [In continuation of G.-8, 1881]', Session 1, G-01, 17 May 1882.

(1883) 'Reports from Officers in Native Districts [In continuation of G.-1, 1882]', Session II, G-01, 11 June 1883.

Williamson, John, (1865) 'Report of Native Produce Imported into the Ports of Auckland and Onehunga', E-12, 11 August 1865.

\section{New Zealand Gazette*}

Chesson, F W (1864) 'Aborigines Protection Society', Volume 20, 21 May 1864 
Earle, E P (1910) 'Applications to the Native Land Court ...Whangamarino, Taupiri, Koheroa, Mangapiko and Ngaroto', Issue 59, 6 June 1910.

Fox, William (1864) '[To raise a loan of one million dollars)', Volume 34, 5 September 1864.

Goring, Forster (1865) 'Proclaiming certain lands under New Zealand Settlements Act, 1863', Volume 1, 5 January 1865.

Grey, George (1864) 'Proclamation [for Clemency]', Volume 41, 25 October 1864.

(1865) 'Proclamation [Retain land in the Waikato]', Volume 49, 17

December 1864.

(1865) 'Notification to Claimants for Compensation under authourity of the New Zealand Settlements Act 1863', Volume 3, 31 January 1865.

(1865) 'Calling on Native Tribes to come in and give themselves up', Volume 11, 7 April 1865.

(1865) 'Constituting the Waikato Militia District', Volume 49, 22 December 1865.

Holland, A.G (1909) 'Applications to the Native Land Court...Whangamarino, Taupiri and Koheroa should be granted', Issue 94, 4 November 1909.

Robinson, Hercules, (1879) 'A Proclamation: Reserves made under Section 4, Confiscated Lands Act 1867', 23 October 1879.

Robinson, Hercules (1879) 'Warrant setting apart Land for Rebel Natives under “Confiscated Lands Act, 1867”, 23 October 1879.

Rogan, Mr, (1867) 'Native Secretary’s Office’, 17 April 1867. 
(1913) 'Exempting a Native from the Provisions of the Native Land Act, 1909, with respect to Landless Natives, and consenting to the Confirmation of an Alienation by the Māori Land Board', 7 August 1913.

\section{London Gazette}

British Parliament, (1846) 'The Queen's Instructions under the Royal Sign Manual and Signet, accompanying the New Zealand Charter', Issue 20687, 29 December 1846.

\section{New Zealand Case Law}

(1911) O'Rourke v The Ikaroa District Maori Land Board, 31 NZLR 434: Supreme Court.

(1913) Wilson v Herries, 33 NZLR 417: Court of Appeal.

\section{Māori Land Court Minute Book/Māori Land Board references and correspondence regarding the Parish of Whangamarino}

Assistant Surveyor to Wilkinson, 'Re Pokaewhenua for Rebels - Ph Whangmarino', 22 October 1884, Lands and Survey Office (BAAZ), series 1108 57b/2005, Archives New Zealand, Auckland.

Assistant Surveyor to $\mathrm{Mr}$ Stevens, 'Re Pokaewhenua for returned rebels - $\mathrm{Ph}$ Whangamarino', 29 October 1884, Lands and Survey Office (BAAZ), series 1108 57b/2005, Archives New Zealand, Auckland.

Beale, E (1913) to W.H Bower, 'Re Allot. 277 P/Whangamarino - 30 acres', 7 February 1913, Māori Land Court (ACIH), series 16036, MA1/1103.

Blair, N.A (1967) to Robert Urquhart, 'Parish of Whangamarino 512D Section 2 Styles Enterprises Limited, 25 October 1967, Māori Land Court (BACS), series 4948, 81, Archives New Zealand, Auckland. 
(1968) to Robert Urquhart, 'Parish of Whangamarino 512D2', 17 January

1968, Māori Land Court (BACS), series 4948, 81, Archives New Zealand, Auckland.

(1968) to Robert Urquhart, 'Parish of Whangamarino 512D2', 23 February

1968, Māori Land Court (BACS), series 4948, 81, Archives New Zealand, Auckland..

(1968) to Messrs McDermott and McIntosh, 'Allotment 512B Parish of Whangamarino: H.N de Thierry to D.J Styles', 23 August 1968, Māori Land Court (BACS), series 4948, 81e, Archives New Zealand, Auckland.

Bower, W.H (1913) to Beale \& Beale, 're Allot. 277 Whangamarino - (Beale)', 17 February 1913, ACIH, series 16036, MA1/1103, ANZ, Auckland.

(1913) to J. St Clair, Solicitor, 'Allot. 277 Whangamarino', 25 March 1913, ACIH, series 16036, MA1/1103, ANZ, Auckland.

(1913) to J St Clair, 'Allot 277 Whangamarino', 26 March 1913, ACIH, series 16036, MA1/1103, ANZ, Auckland.

(1913) to Office of the Waikato Maniapoto District Native Land Board, 'Whangamarino Lot 277', 24 June 1913, ACIH, series 16036, MA1/1103, ANZ, Auckland.

(1913) to J St Clair, 're Whangamarino Lot 277. (Beale)', 4 July 1913, ACIH, series 16036, MA1/1103, ANZ, Auckland.

(1913) to J St Clair, 're Whangamarino Lot 277 (Beale), 23 August 1912, ACIH, series 16036, MA1/1103, ANZ, Auckland.

Brook, M.A (1960), 'Parish of Whangmarino Lot 512F: Application for meeting to consider lease or sale to R.J. Ellmers', Auckland-Thames Alienations Minute Book, Volume 1, 20 October 1960. 
(1961), 'Whangamarino 512', Auckland-Thames Alienation Minute Book, Volume 1, January 1961.

(1961) 'P/Whangmarino 512F, P/Whangmarino 512E: Application for meeting to consider lease to Ellmers', Auckland-Thames Alienation Minute Book, Volume 1, 27 January 1961.

(1961) 'Parish of Whangamarino Lot 512F, Parish of Whangamarino Lot 512E': Application for meetings to consider lease to Ellmers', Auckland-Thames Alienation Minute Book, Volume 1, 22 March 1961.

(1961) 'Parish of Whangamarino Lot 512E, Parish of Whangmarino Lot 512F - Application for confirmation of resolutions to sell to R.J Ellmers', Waikato Alienation Minutes Book, Volume 4, 15 June 1961.

-(1961) 'Parish of Whangamarino Lot 512E, Parish of Whangamarino Lot 512F - Resolutions to sell to Ellmers', Waikato Minute Book, Volume 4, 14 September 1961.

(1961) 'Whangamarino 512E, Whangamarino 512F - Resolution to sell to R.J Ellmers', Waikato Maniapoto Minute Book, Volume 4, 21 September 1961.

(1961) 'Whangmarino Lot 512F, Whangamarino Lot 512E: Resolution to sell to R.J Ellmers', Waikato Minute Book, Volume 4, 21 September 1961.

(1963) 'Whangamarino 512B...512C...512D2', Waikato Alienations Minute Book, Volume 5, 4 September 1963.

(1963) 'Whangamarino 512B, Whangamarino 512C, Whangamarino 512D2 - Applications for meetings to consider sales to Harvey’, Waikato Minute Book, Volume 5, 3 October 1963.

(1963) 'Parish of Whangmarino Lot 512', Waikato Minute Book, Volume 74, 12 October 1963. 
(1964) 'Whangamarino 512B', Waikato Alienation Minute Book, Volume 5, 4 September 1964.

(1964) 'Order for Removal of restrictions on alienations: In the matter of the lands known as Parish of Whangamarion Lot 512A, 512B, 512C, 512F', Mercer Minute Book, Volume 35, Māori Land Court, 19 September 1964.

(1964) 'P/Whangamarino Lot 512B', Mercer Minute Book, Volume 43, 24 November 1964.

(1964) 'Whangamarino 512B' re Order confirming Resolution of Assembled Owners, 30 November 1964, Māori Land Court (BACS), series 4948, 81e, Archives New Zealand, Auckland.

(1964) 'Whangamarino 512B - Resolution to sell to Henry Noel de Thierry', Mercer Minute Book, Volume 43, 30 November 1964.

(1964) 'Whangamarino 512B', Order Confirming Resolution of Assembled Owners, 30 November 1964, Māori Land Court (BACS), series 4948, 81e, Archives New Zealand, Auckland.

(1964) 'Block Whangamarino 512B', Document for Execution, 11 December 1964, Māori Land Court (BACS), series 4948, 81e, Archives New Zealand, Auckland.

(1965) 'Consolidation order', Mercer Minute Book, Volume 43, 2 March 1965.

(1968) 'Lot 512D2 Parish of Whangamarino - Section 438', Waikato Minute Book, Volume 46, 26 March 1968.

(1968) 'Parish of Whangamarino 512D2: Application for meeting to consider sale to Styles Limited', Waikato Minute Book, ,Volume 6, 13 June 1968. 
Carter, G.D (1930) 'Whangamarino 512D', Partition Order, Mercer Minute Book, Volume 30, 13 May 1930.

(1948) 'Parish of Whangamarino 512D 2', Partition Order, Mercer Minute Book, Volume 30, 17 August 1948.

(1993) 'Parish of Whangamarino Lot 512', Waikato Minute Book Volume 74, 1993.

(1993) Memorandum from Judge Carter to Mr Archibald, 'Re: Parish of Whangamarino 512 Block - Section 34(9B)/53', 9 June 1993.

(1993) 'Parish of Whangamarino Lot 512', Waikato Minute Book, Volume 74, 12 October 1993.

(1994) 'Memorandum to Parties: In the matter of applications under Section 34/(9)(B)/53 and 452/53 affecting Parish of Whangamarino Lots 512C and 512D Blocks', 11 July 1994, Māori Land Court (BACS), series 4948, 81, Archives New Zealand, Auckland.

(1995) 'Whangamarino 512D1- Section 338/93', Waikato Minute Book, Volume 78, 30 October 1995.

(1995) 'Whangamarino 512D2', Waikato Minute Book, Volume 78, 30

October 1995.

(1995) 'Whangamarino 512D2', Waikato Minute Book, Volume 78, 30 October 1995.

(1995) 'Parish of Whangamarino Lot 512', Waikato Minute Book, Volume 78, 10 November 1995.

(1995) 'Lot 512', Waikato Minute Book, Volume 78, p.219. 
Cull, K.B (1930) 'Parish of Whangamarino Lot 512A1', Partition Order, 13 May 1930.

Davis (Puru), Elsie (1992) to Letter to New Zealand Historic Places Trust, 29 September 1992, Private Papers.

(1995) to Sue Maruiohoho (Ngā Marae Topu) and John Te Maru (Tainui Māori Trust Board), 20 October 1995, Private Papers.

De Thierry, H.N (1964) 'Parish of Whangamarino Lot 512B', Application to summon a meeting of owners, 7 August 1964, Māori Land Court (BACS), series 4948, 81e, Archives New Zealand, Auckland.

Ellmers, R.J (1961) to The Registrar, 1 March 1961, Māori Land Court (BACS), series 4948, 1591g, Archives New Zealand, Auckland.

Finlayson, Darby (1968) in M.A Brook, 'Lot 512D2 Parish of Whangamarino: Section 438', in Māori Land Court, Waikato Minute Book, Volume 46, 26 March 1968.

Foster, Mr (1964) 'P/Whangamarino Lot 512C', Mercer Minute Book, Volume 42, 9 June 1964.

(1964) 'P/Whangamarino Lot 512C', Mercer Minute Book, Volume 43, 18 June 1964.

Harvey, L.K (1963) 'Application to summon a meeting of owners - Whangamarino 512D2', 10 July 1963, Māori Land Court (BACS), series 4948, 81, Archives New Zealand, Auckland.

King, Miss, (1993) Lawyer in support of owners in Lot 512D, 'Parish of Whangamarino Lot 512', Waikato Minute Book Volume 74, 1993.

Maori Land Court (1948) 'Whangamarino 512D1 set apart as a Maori Reservation', Waikato-Maniapoto Minute Book, Volume 30. 
Māori Land Court (1990) 'Whangamarino 512D2 Block: Section 438(3)(a) and (b)/53', Waikato Minute Book, Volume 70, 11 December 1990.

McDermott \& McIntosh, (1968) 'Re: Lease of Allotment 512B Parish of Whangamarino, H.N De Thierry to D. J Styles', 21 August 1968, Māori Land Court (BACS), series 4948, 81e, Archives New Zealand, Auckland.

McCormick Judge, (1927) 'Whangamarino Decision', Mercer Minute Book, Volume 24.

-(1930) 'Parish of Whangamarino Lot 512C', Partition Order, 13 May 1930, Māori Land Court (BACS), series 4948, 1038d, Archives New Zealand, Auckland.

Morrison, E.R (1961) "Parish of Whangamarino Lot 512F", Statement of Proceedings of Meeting of Assembed Owners, 10 May 1961, Māori Land Court (BACS), series 4948, 1592b, Archives New Zealand, Auckland.

Nepe, Te Kere (1968) in M.A Brook, 'Lot 512D2 Parish of Whangamarino: Section 438', in Māori Land Court, Waikato Minute Book, Volume 46, 26 March 1968

Ovington, P.J (1963) to J.C Black, 'Whangamarino 512B, 512C, 512D2 - Lloyd Kelton Harvey', 18 July 1963, Māori Land Court (BACS), series 4948, 81e, Archives New Zealand, Auckland.

(1963) to J.C Black, 'Whangamarino 512B, 512C and 512D Blocks', 30 September 1963, Māori Land Court (BACS), series 4948, 81e, Archives New Zealand, Auckland.

(1963) to J.C Black, 'Whangamarino 512C: 512C: 512B', 11 October 1963, Māori Land Court (BACS), series 4948, 81e, Archives New Zealand, Auckland. [Please note spelling mistake has been left unamended] 
(1963) 'Whangamarino 512B' re Statement of Proceedings of Meeting of Assembled Owners, 30 October 1963, Māori Land Court (BACS), series 4948, 81e, Archives New Zealand, Auckland.

(1963) 'Whangamarino 512D2 Block', Report of Recording Officer at Meeting of Assembled Owners, 30 October 1963, Māori Land Court (BACS), series 4948, 81, Archives New Zealand, Auckland.

Palmer (1968) in M.A Brook 'Lot 512D2 Parish of Whangamarino: Section 438', in Māori Land Court, Waikato Minute Book, Volume 46, 26 March 1968.

Patterson, Mr (1964) 'P/Whangamarino Lot 512C', Mercer Minute Book, Volume 43, 17 September 1964.

(1964) 'Whangamarino Lot 512C', Mercer Minute Book, Volume 43, 22 October 1964.

Roberts, C.A (1961) to Registrar, 'Parish of Whangamarino 512E \& F: Sale to Ellmers', 18 August 1961, Māori Land Court (BACS), series 4948, 1591g, Archives New Zealand, Auckland.

Shelford, Rawinia (nee Puru Te Tahua) in M.A Brook, 'Parish of Whangamarino Lot 512E, Parish of Whangmarino Lot 512F - Application for confirmation of resolutions to sell to R.J Ellmers', Waikato Alienation Minutes Book, Volume 4, 15 June 1961.

St Clair, J (1912) 'Application for Confirmation: Lot 277 Whangmarino', 21 October 1912, ACIH, series 16036, MA1/1103, ANZ, Auckland.

(1913) 'Whangamarino Lot 277: Application for a recommendation for Order in Council dispensing other lands", Application to the Waikato Maniapoto District Māori Land Board, 13 May 1913, ACIH, series 16036, MA1/1103, ANZ, Auckland. 
(1913) 'Lot 277 Whangamarino - 30 acres: Application for recommendation under Section 425 for Order in Council dispensing with Other Lands re sale to M.E.H.Beale' in Waikato Alienations, Volume 10, 10 June 1913.

(1914) "Kua utua mai kia maua e Mrs Beale nga moni e ono te kau pauna ara te moni katoa o te hoko o Rota 277 Parihi o Whangamarino e 30 eka kia Mrs Beale", 5 February 1914, ACIH, series 16036, MA1/1103, ANZ, Auckland.

Styles Enterprises Ltd (1967) 'Application to summon a meeting of owners: Whangamarino 512D2', 19 October 1967, BACS, series 4958, 818/1170, ANZ, Auckland.

Te Waari, Tarehurangi (1927) 'Whangamarino 512', Mercer Minute Book, Volume 16, 23 January 1912, p.233 and Judge McCormick, Mercer Minute Book, Volume 24, 27 August 1927.

Tupuhi, Amo (1913) to Waikato Maniapoto District Native Land Board, 6 June 1913, ACIH, series 16036, MA1/1103.

Robert Urquart (1967) to Registrar, 'Parish of Whangamarino Lot 512D. No.2', 17 October 1967, BACS, series 4958, 818/1170, ANZ, Auckland.

(1968) 'Lot 512D2 P/Whangamarino', in Māori Land Court, Waikato Minute Book, Volume 46, 13 June 1968..

Wanakore, Judith-Anne (1995) in Māori Land Court, 'Whangamarino 512D2', Waikato Minute Book, Volume 78, 30 October 1995.

Waikato Alienation Minute Book, (1913) 'Lot 277 Whangamarino', Volume 9, 23 March 1913.

Waikato Maniapoto District Native Land Board, (1913) 'Lot 277 Whangamarino: Applicantion for confirmation of transfer to Margaret E.H.Beale' in Waikato Alienation Minute Book, Volume 9, 26 March 1913. 
(1913) 'Lot 277 Whangamarino', Waikato Alienation Minute

Book, Volume 10, 10 June 1913.

(1914) 'Whangamarino Lot 277 (Beale)', Waikato Alienation

Minute Book, Volume 11, 26 February 1914.

Wilkinson, G.T (1884) to Assistant Surveyor General, 'Re Pokaewhenua', 20 October 1884, Lands and Survey Office (BAAZ), series 1108 57b/2005, Archives New Zealand, Auckland.

(1890) 'With regard to mistake as to position of Takapuruhauha

Settlement', Memo for Under Secretary, 23 October 1890, Lands and Survey Office (BAAZ), series 1108, 58a, Archives New Zealand, Auckland.

(1890) to the Native Office, 'Whangamarino Parish', 23 October 1890,

Lands and Survey Office (BAAZ), series 1108, 58a, Archives New Zealand, Auckland.

Waikato Māori Land Court Block Order Files: Parish of Whangamarino

Lot 182,

Lot 213

Lot 214

Lot 215

Lot 245

Lot 246

Lot 247

Lot 248

Lot 249

Lot 250

Lot 251

Lot 255

Lot 260

Lot 261 
Lot 268

Lot 271

Lot 277

Lot 278

Lot 304

Lot $332 \mathrm{a}$

Lot 335

Lot 393

Lot 442

Lot 471

Lot 473

Lot 512

\section{Archives New Zealand references**}

AADS W3562/33/36/1129 - Whangamarino block 1924-1933

AADS W3562/288 22/747/212 - Allotment 210 Parish of Whangamarino AADS W3740/F282/864 - Auckland Land District Lands for Sale...in Whangmarino AADS W3740/F282/866 - Auckland Land District Lands for Sale...in Whangmarino AADS W3740/F289/1014 -Auckland Land District Lands for Sale...in Whangmarino AADS W3740/F291/1050 - Auckland Land District Whangamarino Parish AADS W3740/F299/1218 - Auckland Land District Parishes of...Whangmarino... AAMK W3074/869/3 - Department Policy and Organisation...1940-1960. AAMK W3074/869/1153 - Utlisation of Māori Land - Policy AAMX 6095/W3430 46/26/1533 Pt 1 - Section 441, Whangamarino Parish ACGT 18190/LS1/1740-General Settlement of...lands at Whangamarino ACGT 18718/LSDrawer/6 - Auckland Survey Districtsion - Whangmarino...

ACIH 16036/MA1/1076 - Received $11^{\text {th }}$ June 1912 - From Puru Te Tahue... ACIH 16036/MA1/1103 - Received $10^{\text {th }}$ July 1913 ...Lot 277 ...Section 425/1909 ACIH 16036 W2490/212/48/1-1 - Utilisation of Māori Land Policy 1948-1952 ACIH 16036 W2490/212/48/1-2 - Utilisation of Māori Land Policy 1953-1960 ACIH 16036 W2490/212/48/2/1-2 - Utilisation of Māori Land Policy 1960-1963 ACIH 16036 W2490/316/69/4 Pt 2 - Policy regarding alienations of Māori land 19631970 
ABWN 8102 W5279/151 - Koheroa, Whangamarino - Mangatāwhiri 1874-1874

BAAZ 1108/57b - Survey Files - Whangamarino Parish 1880-1890

BAAZ 1108/58a - Survey Files - Whangamarino Parish 1890-1891

BAAZ 1108/58b - Survey Files - Whangamarino Parish 1891-1900

BAAZ 1108/59a - Survey Files - Whangamarino Parish 1900-1904

BAAZ 4699/1/a - Return...lands..awarded to Natives by Compensation Court

BACS 4958/818/17/1170 - Land Alienation - Parish of Whangamarino Lot 512D

BACS 4958/1503f 17/1251 - Land Alienation - Parish of Whangamarino Lot 393e

BACS 4958/1506h/17/1794- Land Alienation - Parish of Whangmarino Lot 393c

BACS 4958/1507 - Land Alienation - Parish of Whangamarino Lot 393G1

BACS 4958/1521 - Land Alienation - Parish of Whangamarino Lot 393K

BACS 4958/1526h/17/1997-Land Alienation - Parish of Whangamarino Lot 234A3B

BACS 4958/1528g/17/2014 - Land Alienation - Whangamarino 442B1

BACS 4958/1544d/17/2168 - Land Alienation - Whangamarino Lot 299A

BACS 4958/1573h/17/327 - Land Alienation - Parish of Whangamarino Lot 323A

BACS 4958/1586c/17/613 - Land Alienation - Parish of Whangamarino Lot 473

BACS 4958 1586c 17/613 - Land Alienation - Parish of Whangmarino Lot 473b

BACS 4958/1590i/17/709 - Land Alienation - Parish of Whangamarino Lot 233G2

BACS 4958/1590j/17/710 - Land Alienation - Parish of Whangamarino Lot 233G1

BACS 4958/1591g/17/738 - Land Alienation - Parish of Whangamarino Lot 512E

BACS 4958/1592b/17/759 - Land Alienation - Parish of Whangamarino Lot 512F

BACS 4958/1593b/17/783 - Land Alienation - Parish of Whangamarino Lot 471A2B

BACS 4958/1593f/17/791 - Land Alienation - Parish of Whangamarino Lot471A1

BACS 4958/1593g/17/792 - Land Alienation - Parish of Whangamarino Lot 471B

BACS 4958/1592b/17/759 - Land Alienation - Parish of Whangamarino Lot 512F

BACS 4958/1591g/17/738 - Land Alienation - Parish of Whangamarino Lot 512E

BACS A110/15355/39 - Land Alienation - Whangamarino 174: Puru te Wheoro

BACS A449/4958/81e/17/1168 - Land Alienation - Whangamarino 512B

BACS A449/4958/81 - Land Alienation - Whangamarino 512D2

BAOB 1542/A1076/246a/9/46 - Whangamarino Parish 1913-1951

BAOB 1542/A1076/274h/9/137 - Whangamarino Parish 1914-1919

BAOB 1542/A1076/280c/9/154 - Whangamarino Parish 1921-1921

BAOB 1542/1051c/3/1536 - Whangamarino Development Block 1931-1931

BAOB 1542/1052a/3/1536 - Whangamarino Development Block 1931-1932 
BBAG 1542/2024a 4/69 - Whangamarino Farm Settlement (Parish) 1916-1949

BBHW 4958/879g/7/516 - Whangamarino Lot 471B

BBHW 4958/885b/7/598 - Whangamarino 471A1

BBHW 4958/1038d/7/682 - Whangamarino 512C 1965-1986

BBHW 4958/1076/ - Whangamarino Lot 393G1

BBHW 4958/1076d/7/942 - Whangamarino 393G2B

BBHW 4958/1076e/7/944 - Whangamarino 393G2A

BBHW 4958/1076f/7/945 - Whangamarino 393G2B

BBHW 4958/1067/g/7/946 - Whangamarino 393E

MA 1/452 21/3/383 - Whangamarino Parish Lot 233a Māori Reserve

MA1 1121/1914/994 Part One - Subject: Part 1 Royal Commission...1914-1926

MA1 1121/1914/994 Part Two- Subject: Part 2 Royal Commission...1914-1926

MA1 1121/1914/994 Part Three- Subject: Part 3 Royal Commission...1914-1926

\section{Government Reports/Publications/Correspondence}

Agriculture, Department of (1950) Farming in New Zealand, Wellington, Hutcheson, Bowman and Stewart Limited. (1974) Farming in the Waikato, Hamilton, Department of Agriculture.

(2000a) New Zealand Agriculture: Waikato Agriculture Farming Systems, Wellington, Ministry of Agriculture.

(2000b) New Zealand Agriculture: Waikato Agriculture A Regional Introduction, Wellington, Ministry of Agriculture.

Agriculture and Forestry, Ministry of (2011) Maori Agribusiness in New Zealand: A Study of the Maori Freehold Land Resource, March 2011.

Apperley, I.W (1965) 'Dealings in Maori Land', Department of Maori Affairs Head Office, 22 January 1965, Māori Affairs (ACIH), series 16036, W2490/212, Archives New Zealand, Wellington. 
Booth, J.M (1966) to Secretary of Māori Affairs, 'Sales of Maori Land', 12 September 1966, Māori Affairs (ACIH), series 16036, W2490/212, Archives New Zealand, Wellington.

Butler, D C (1962) to Minister of Māori Affairs (J R Hanan), 'Utilisation of Unproductive Māori Land', 30 May 1961, Māori Affairs (ACIH), series 16036, W2490/212, Archives New Zealand, Wellington.

Fisheries, Ministry of Agriculture and (1972) 'Farming in the Waikato', Hamilton, Ministry of Agriculture and Fisheries.

(2000a) 'New Zealand Agriculture: Waikato Agriculture - Farming Systems', Wellington, Ministry of Agriculture and Fisheries.

(2000b) 'New Zealand Agriculture: Waikato Agriculture - A Regional Introduction', in Ministry of Agriculture and Fisheries, Wellington, Ministry of Agriculture and Fisheries.

Forestry, Ministry of Agriculture and (2011) MAF briefing for incoming Ministers, Wellington, Ministry of Agriculture and Forestry.

(2011), 'Briefing for Incoming Ministers',

Wellington, Ministry of Agriculture and Forestry.

Hunn, J K (1962) to General Secretary of the New Zealand Dairy Production \& Marketing Board, 'Māori Leaseholds', 28 May 1962, Māori Affairs - Head Office (AAMK) series 869, W3074/1153, Archives New Zealand (ANZ).

Hutton, John (1996) 'The Operation of the Waikato-Māori District Māori Land Board', Report written for the Crown Forestry Rental Trust, 3 May 1996. 
Internal Affairs, Department of (2013) Death Certificate (extracted from the Māori register), 'Te Aomarama Puru [Registry No. 1958039170]', Register of Birth, Deaths and Marriage, Wellington.

Lands and Survey, Department of (1974) Land Settlement Scheme: Crown Farms for Allotment by Ballot, Wellington, Department of Lands and Survey.

(1976) 'The Department of Land and Survey: 18761976', Wellington, Department of Land and Survey.

(1977) Land Settlement Scheme: Crown Farms for Allotment by Ballot, Wellington, Department of Lands and Survey, 1977.

(1977) 'Activities of the Department of Land and Survey', Wellington, Department of Land and Survey.

(1979) Land Development in New Zealand, Welllington, Department of Lands and Survey, 1979.

Māori Affairs, Department of (1957) 'The Minister of Maori Affairs', 16 December 1957, Maori Affairs - Head Office (AAMK), series 869, W3074/3, Archives New Zealand, Wellington.

(1960) 'Report of Interdepartmental Committee of Investigation into Deterioration of East Coast Farming Land', Māori Affairs - Head Office (AAMK), series 869, W3074/1153, Archives New Zealand, Wellington.

(1989) 'He Kaupapa Korero: Te Hurihanga o te Ao Maori: Te Ahua o te iwi Maori kua Whakatatutia', Wellington, Department of Maori Affairs.

Maori Trust Office Review Team (1991), Review of the Office of the Maori Trustee, Rotorua, Department of Māori Affairs. 
Māori Affairs, Department of and Māori Trust Office, (1984) 'A Brief Summary of the Activities of the Department and of the Māori Trustee', Wellington, Department of Māori Affairs.

McKeller, M.G (1979) The Role of the Màori Trustee: Report of the, Committee appointed to Review the operations of the Mãori Trustee, Wellington, Department of Māori Affairs.

McLellan, Nathan (2004) 'Measuring Productivity using the Index Number Approach: An Introduction', Wellington, New Zealand Treasury.

Pritchard, Ivor and Hemi Waetford (1965) 'Report of Committee of Inuiry into Laws affecting Maori land and Powers of the Maori Land Court', in Department of Maori Affairs, ed., Wellington, Department of Maori Affairs.

Ritchie, Neville (2007) 'The Waikato War of 1863-64: A guide to the main events and sites', in Department of Conservation, ed., Department of Conservation.

Ropiha, T (1949) 'Notes of Tribal meeting at Te Kuiti', Te Kuiti, 6 April 1949, Māori Affairs (MA), series W2490, 212/48, ANZ, Wellington.

-(1950) 'Memorandum for the Hon. Minister of Māori Affairs: Utilization of Maori Land', 17 August 1950, Māori Affairs (MA), series W2490, 212/48, ANZ, Wellington.

Royal Commission of Inquiry (1980) 'The Maori Land Courts', Wellington, House of Representatives.

Statistics, Department of (1963) The New Zealand Official Yearbook, Wellington, Department of Statistics. 
Te Puni Kokiri, (2011) 'Ko Nga Tumanako o Nga Tangata Whai Whenua Maori: Owner Aspirations Regarding the Utilisation of Maori Land', Wellington, Te Puni Kokiri, April 2011.

(2013) 'Discussion Document: Te Ture Whenua Maori Act, 1993

Review Panel', Wellington, Te Puni Kokiri, March 2013.

\section{Correspondence*}

Lloyd, G (1949) to the Prime Minister, 27 January 1949, Māori Affairs - Head Office (AAMK) series 869, W3074/1153, Archives New Zealand, Wellington.

McEwen, J.M (1966) to New Zealand Maori Council, 'Sales of Maori Land', 21 September 1966, Māori Affairs (ACIH), series 316, W2490/69/4 PT2, Archives New Zealand, Wellington.

\section{Oral Sources}

Puru, Ngawini, Interview, 4 October 2011, Auckland.

Roa, Tom, in Hineani Melbourne, 'Rangiriri - The 150th Anniversary of the Land Wars in Waikato, Waka Huia, Auckland, TVNZ, 4 May 2014, 11min

Tauariki, Moko, Presentation, 19 October 2013, Rangiriri.

\section{Theses}

Aims, E.J (1929) 'Dual control of native policy; a phase of responsible government in New Zealand, Masters Thesis in Arts, Victoria University of Wellington.

Bates, T.W (1947) The Administration of Thomas Gore Browne, Governor of New Zealand 1855-1961, Master of Arts Thesis in History, Victoria University of Wellington. 
Harris, Aroha (2007) 'Dancing with the state: Māori creative energy and policies of integration: 1945-1967', PhD Thesis, University of Auckland.

Loader, Arini (2013) 'Tau mai e kapiti te whare wananga o ia, o te nui, o te wehi, o te toa: reclaiming early raukawa-toarangatira writing from otaki', $\mathrm{PhD}$ Thesis, Victoria University of Wellington.

McKinney, Jack Bolton (1939) 'The Evolution of a Legal Title to Land Formerly Held Under Maori Custom and Usage, Or, The Effect of Native Land Laws on Maori Custom, Masters Thesis, Victoria University College.

Mead, L (1996) Nga aho o te kakahu matauranga : the multiple layers of struggle by Maori in education, PhD Thesis, University of Auckland.

Morton, S.M (1946) 'The confiscation of the "Northern blocks" of the Waikato and their Settlement by assisted immigrants', Doctoral Dissertation, Auckland University College.

Murray, Nigel (2006) 'Racism \& Empire: Discourses of Race and Empire in the formation of New Zealand's national identity 1894-1907', Master of Arts Thesis, Victoria University of Wellington.

Muru-Lanning, M (2010) 'Tupuna awa and te awa tupuna - an anthropological study of competing discourses and claims of ownership to the Waikato river', $\mathrm{PhD}$ Thesis, University of Auckland.

Pihama, L (2001) Tihei Mauri Ora, Honouring our Voices: Mana Wahine as a Kaupapa Māori Theoretical Framework, PhD Thesis, University of Auckland.

Pitama, S (2013) 'As natural as learning pathology: The design, implementation and impact of Indigenous health curricula within medical schools', PhD Thesis, University of Otago.

Roskruge, N (2007) 'Hokia ki te whenua', PhD Thesis, Massey University. 
Webb, E.N. (1942) 'A Policy of Land Confiscation with Special Reference to the Problems arising from it after the war in the Bay of Plenty', Doctoral Dissertation, University of New Zealand.

Young, G (2003) 'Nga Kooti Whenua: The Dynamics of a Colonial Encounter', PhD Thesis, Massey University.

\section{Unpublished sources}

Bauchop, Heather (1993) 'The Aftermath of Confiscation - Crown Allocation of Land to Iwi: Taranaki 1865-80: A Case Study in confusion', Waitangi Tribunal WAI 143, Document 118, June 1993.

Bennion, Tom (1997) The Maori Land Court and Land Boards, 1909 to 1952, Rangahaua Whanui National Theme F, Wellington, Waitangi Tribunal.

Commission, New Zealand Law (2001) 'Maori Customs and Values in New Zealand Law', Study Paper No. 9, Wellington, New Zealand Law Commission.

Coopers, Price Waterhouse (2013) 'Growing the productive base of Māori Freehold Land', Report commissioned by the Ministry of Primary Industries, February 2013.

Fairweather, John R (1985) 'Land Policy and Land Settlement in New Zealand: An Analysis of Land Policy Goals and an Evaluation of their Effect', University of Canterbury, Agricultural Economics Research Unit.

Gilling, B (2007) 'The Most fundamental desire of Maori Landowners': Land Management and Governance Options for Maori from the 1950s', in Treaty of Waitangi Research Unit, ed., Rangatiratanga Series, Wellington, Treaty of Waitangi Research Unit.

Harris, Aroha (1993) 'Crown Acquisition of Confiscated and Maori Land in Taranaki, 1872-81', Wellington, Waitangi Tribunal Division, Department of Justice. 
Hayes, B E (2000) 'The Certificate of Correctness under the Land Transfer Act', Wellington, Land Information New Zealand.

Hayes, Robert (2000) 'A Study of the origins of the crown's policy on Imposing restrictions on land alienation and its administration', Research report commissioned by the Crown Law Office.

Henare, Denese (1992) 'The Raupatu Claim of Tainui', Maori Claims and Rights to Natural Resources, Auckland, Energy and Natural Resources Law Association of New Zealand Incorporated.

Hill, Richard (1989) 'Enthroning "Justice Above Might"?: The Sim Commission, Tainui and the Crown', in Department of Justice, ed., Wellington, Treaty of Waitangi Policy Unit.

Husbands, P and Riddell, Kate (1993) 'The Alienation of South Auckland Lands', Waitangi Tribunal Research Series, Wellington, Waitangi Tribunal Division, Ministry of Justice.

Johnson, Ralph (1997) 'The Trust Administration of Māori Reserves, 1840-1913', Rangahaua Whanui National Theme L, Wellington, Ministry of Justice.

Loveridge, Donald, (2000) 'The Origins of the Native Lands Acts and Native Land Court in New Zealand', Evidence of Donald Loveridge concerning the origins of the Native Land Acts and Native Land Court in New Zealand, WAI No 686 and WAI 100 \& Ors, Wellington, Crown Law Office.

Mahuta, Robert (1988) 'Raupatu and its impact on Waikato attitudes', Centre for Maori Studies and Research, New Zealand Psychological Society, 16 August 1988.

McHugh, P.G (2010) 'Raupatu and the Writing of New Zealand Legal History: An Introductory Essay', Law and Confiscation: Essays on Raupatu in New Zealand History Number 14, Wellington, Treaty of Waitangi Research Unit. 
McHugh, P.G et al. (2009) 'Law and Confiscation: Essays on Raupatu in New Zealand History', Wellington, Treaty of Waitangi Research Unit.

O'Malley, Vincent (1995) 'The Aftermath of the Tauranga Raupatu 1864-1981', The Crown Forest Rental Trust.

(2000) 'An Entangled Web: Te Aitanga a Mahaki Land and Politics, 1840-1873, and their Aftermath', Wellington, Te Aitanga a Mahaki Claims Committee.

Parsonson, Ann (1995) 'Tainui Claims to Onewhero and Maramarua Forests: Historical Overview', Scoping Report commissioned by the Tainui Māori Trust Baord in association with the Crown Forest Rental Trust.

Penetito, Wally (2011) 'Keynote: Kaupapa Maori Education: Research at the Exposed Edge', in Jessica Hutchings et al, eds., Kei Tua o te Pae Hui Proceedings: The Challenges of Kaupapa Maori Research in the 21st Century, Pipitea Marae, Wellington, New Zealand Council for Educational Research, pp.38-43.

Pihama, L et al. (2004) 'A Literature Review on Kaupapa Maori and Maori Education Pedagogy', The International Research Institute for Maori and Indigenous Education.

Powick, Kiri (2002) 'Maori Research Ethics: A Literature of the Ethical Issues and Implications of Kaupapa Maori Research involving Maori for Researchers, Supervisors and Ethics Committees', Hamilton, Wilf Malcolm Institute of Educational Research.

Raupatu Document Bank, 'Index of Native Land Compensation Awards', Vol 104, 1867.

Schmidt, Kieran and Fiona Small, (1996) 'The Māori Trustee: 1913-1953', Report for the Crown Forestry Rental Trust, 1996.

Scott, K. G. (1964) 'The role of the Māori Land Court in Land Utilisation', Address given at the Leadership Conference, Kaikohe, 17 April 1964. 
Settlements, Office of Treaty (2009) 'Initial Departmental Briefing on the WaikatoTainui Raupatu Claims (Waikato River) Settlement Bill: Prepared for the Maori Select Committee', Wellington, Office of the Treaty Settlements, Ministry of Justice.

Smith, Graham (1992) 'Research Issues Related to Maori Education, paper presented to NZARE Special Interest Conference, reprinted in 1992', The Issue of Research and Māori, Auckland, Research Unit for Maori Education, University of Auckland.

Smith, Linda (2011) 'Opening Keynote: Story-ing the Development of Kaupapa Maori A Review of Sorts', Kei Tua o te Pae Hui Proceedings: The Challenges of Kaupapa Maori Research in the 21 st Century, Wellington, New Zealand Council for Educational Research, pp.10-15.

Somerville, Alice Te Punga (2011) 'Neither Qualitative nor Quantitative: Kaupapa Māori, Methodology and the Humanities', Kei Tua o te Pae: The Challenges of Kaupapa Māori Research in the $21^{\text {st }}$ Century, Wellington, New Zealand Council for Educational Research, Pipitea Marae, Wellington, 5-6 May 2011.

Stokes, Evelyn (1985) 'Māori Research and Development', A discussion paper prepared for the Social Committee of the National Research Advisory Council, University of Waikato, February 1985.

Totorewa, B. (2013) A Review of the Right of First Refusal within the 1995 WaikatoTainui Raupatu Settlement, unpublished Major Research Project paper for the Masters of Business Administration, University of Waikato.

Victoria R. (1840) 'Instructions to our trusty and well-beloved William Hobson, Esq. our Governor and Commander-in-Chief in and over Our Colony of New Zealand', in William Hobson, ed., London, British Parliamentary Papers.

Walker, Ranginui (2004b)'A consumer view on research', Paper delivered to the Minterial Conference on Educational Research, 19 April 1978 
Walsh-Tapiata, W (1998) 'Research within your own iwi - What are some of the issues?', Te Oru Rangahau Maori Research and Development Conference, Massey University, Palmerston North, pp.249-56.

Ward, A (1997) 'National Overview: Volume 1: Waitangi Tribunal Rangahaua Whanui Series', Wellington, Waitangi Tribunal.

-------- (1997b) 'National Overview: Volume 2: Waitangi Tribunal Rangahaua Whanui Series', Wellington, Waitangi Tribunal.

(1997c) 'National Overview: Volume 3: Waitangi Tribunal Rangahaua Whanui Series', Wellington, Waitangi Tribunal.

Wickliffe, C et al. (2002), 'Access to Customary Law: New Zealand Issues: Visible Justice: Evolving Access to Law', Wellington, pp.1-9.

Wilkinson, George T, 'Papers, 1878-1904', Auckland War Memorial Museum Library, MS 613.

Williams, Joe (2001) 'The Maori Land Court - A Separate Legal System', Wellington, New Zealand Centre for Public Law, Faculty of Law.

Wilkie, Margaret (2004-2005) 'Kaupapa Maori Research, Theory and Frameworks in New Zealand Tertiary Education: A Literature Review', in Bruce Duffin, et al., eds., Nga Pae o te Maramatanga: Intern Reports, Auckland: Nga Pae o te Maramatanga, pp.267-95.

Whitehead, John (2008) 'Putting Producitivity First', Speech by Secretary to the Treasury at the Icehouse, Auckland, 3 April 2008.

\section{Published Sources}

A Fleras and Elliott, J (1992) The Nations Within: Aboriginal-State Relations in Canada, the United States, and New Zealand, Toronto Oxford University Press. 
Alfred, Taiaiake (1999) Peace, Power, Righteousness: an Indigenous Manifesto Ontario, Oxford University Press.

Alfred, T and Jeff Corntassel (2005) 'Being indigenous: Resurgences against contemporary colonialism', in Government and Opposition, 40, 4, pp.597-614.

Allen, Michael (2009) 'An Illusory Power? Metropole, Colony and Land Confiscation in New Zealand, 1863-1865', in Richard Boast and Richard Hill, eds., Raupatu: The Confiscation of Maori Land, Wellington, Victoria University Press, pp.110-41.

Altman, J. and M. Cochrane (2005) 'Sustainable development in the indigenous-owned savanna: innovative institutional design for cooperative wildlife management', Wildlife Research, 32, 5, pp.473-80.

Altman, J.C (2004) 'Economic development and Indigenous Australia: contestations over property, institutions and ideology, Australian Journal of Agricultural and Resource Economics, 48, 3, pp.513-34.

Anderson, Chris and Brendan Hokowhitu (2007) 'Whiteness: Naivety, Void and Control', Junctures, 8, pp.39-49.

Anderson, T (2004) 'Living on the Boundaries: Fred Mace and Surveying in NineteenthCentury New Zealand', Graduate Journal of Asia-Pacific Studies, 2, 2, pp.64-76.

Arvidson, Ken (2005) 'A Pre-Settlement Record of Life in the Waikato: The Journals of Benjamin Yate Ashwell', Journal of New Zealand Literature, 23, 1, pp.11-28.

Attard, Bernard (2007) 'From Free-trade Imperialism to Structural Power: New Zealand and the Capital Market, 1856-68', The Journal of Imperial and Commonwealth History, 35,4 , pp.505-27.

Austin, David (2010) 'Narratives of power: historical mythologies in contemporary Quebec and Canada', Class \& Race, 52, 1, pp.19-32. 
Baker, J.V.T (1965) 'War Economy: Food Crisis in Britain', The Official History of New Zealand in the Second World War 1935-1945, Wellington, Historical Publications Branch, pp.490-91.

Banerjee, S.B (2000) 'Whose land is it anyway? National interest, indigenous stakeholders, and colonial discourses', Organization \& Environment, 13, 1, pp.3-38

(2003) 'The practice of stakeholder colonialism: National interest and colonial discourses in the management of indigenous stakeholders', Postcolonial theory and organizational analysis, pp.255-79.

Banner, Stuart (1999) 'Two Properties, One Land: Law and Space in NineteenthCentury New Zealand', Law and Society Enquiry, 24, pp.807-52.

Barsh, R.L (1983) 'Indigenous North America and Contemporary International Law', Oregon Law Review, 62, pp.73-125.

Beaglehole, Ernest (1957) 'The Maori in New Zealand: A Case Study of SocioEconomic Integration', International Labour Review, 76, pp.103-23.

Belgrave, Michael (2002) 'The Tribunal and the Past: Taking a Roundabout Path to a New History', in Michael Belgrave, ed., Waitangi Revisited: Perspective on the Treaty of Waitangi, Auckland, Oxford Unity Press, pp.35-55.

Belgrave, M et al. (2005) Waitangi Revisited: Perspectives on the Treaty of Waitangi, eds., Melbourne, Oxford University Press.

Belich, J (1998) The New Zealand Wars and the Victoria Interpretation of Racical Conflict, Auckland, Penguin Books.

Belshaw, H (1927) 'Dairying Industry in New Zealand', Economic Geography, 2, 3, pp.281-96. 
Tom Bennion, 'Waitangi Tribunal - The Hauraki Report', Māori Law Review, Wellington, Tom Bennion, Wellington, June 2006, pp.1-5.

Berryman, Jeff (1990) 'The Fourth World in the First World - The Maori in New Zealand', Sri Lanka Journal of International Law, 2, pp.37-58.

Binny, Judith (2001) The Shaping of History: Essays from the New Zealand Journal of History, Wellington, Bridget Williams Books.

Bishop, R (1998) 'Freeing ourselves from neo-colonial domination in research: A Maori approach to creating knowledge', International Journal of Qualitative Studies in Educational, 11, 2, pp.199-219.

Blair, Maud (2008) "WWhiteness" as institutionalized racism as conspiracy: understanding the paradigm', Educational Review, 60, 3, pp.249-51.

Boast, Richard (1993) 'Maori and the Law, 1840-2000', in Peter Spiller, Jeremy Finn, and Richard Boast, eds., A New Zealand Legal History, Wellington, Brookers Limited, pp.123-86.

(2004) 'The Evolution of Maori Land Law 1862-1993', in Richard Boast, et al., eds., Maori Land Law, Wellington, Lexis Nexis NZ Ltd, pp.65-119.

(2008) Buying the Land, Selling the Land: Governments and Maori Land in the North Island 1865-1921, Wellington, Victoria University Press.

(2009) 'An Expensive Mistake: Law, Court and Confiscation on the New Zealand Colonial Frontier', in Richard Boast and Richard Hill, eds., Raupatu: The confiscation of Maori Land, Wellington: Victoria University Press, pp.145-168.

(2010a) "An expensive mistake': Law, Courts and Confiscation on the New Zealand Colonial Frontier', in P G McHugh, Richard Boast, and Mark Hickford, eds., Law and Confiscation: Essays on Raupatu in New Zealand History, Number 14, Wellington, Treaty of Waitangi Research Unit, pp.143-168. 
(2010b) 'Contextualising the Decisions of the Native Land Court: The Chatham Islands Investigations of 1870', Victoria University of Wellington Law Review, 41, pp.623-52.

Boast, R et al. (2004) Maori Land Law, Wellington, Lexis Nexis NZ Ltd.

Boast, R and Richard Hill (2009) 'Overview: Confiscation in New Zealand', in Richard Boast and Richard Hill, eds., Raupatu: The confiscation of Maori Land, Wellington, Victoria University Press, pp.3-12.

(2009) Raupatu: The Confiscation of Maori Land, ed.,

Wellington, Victoria University Press.

Bouchier, J M (1976) 'Discretion in the Maori Land Court', Auckland University Law Review, 3, pp.381-400.

Brayboy, BK and D Deyhle (2000) 'Insider-Outsider Researchers in American Indian Communities', Theory into Practice, 39, 3, pp.163-69.

Bronfenbrenner, M (1955) 'The Appeal of Confiscation in Economic Development', Economic Development and Cultural Change, 3, 3, pp.201-18.

Brookfield, F M (2006) Waitangi \& Indigenous Rights: Revolution, Law and Legitimation, Updated edn., Auckland, Auckland University Press.

Brown, D (2002) 'Nga Paremata Maori: The Architecture of Maori Nationalism', Fabrications: The Journal of the Society of Architectural Historians, Australia and New Zealand, 12, 2, pp.1-17.

Buchan, Bruce (2005) 'Subjects of Benevolence: Concepts of society and civilisation in early colonial indigenous administration', Journal of Australian Studies, 29, 85, pp.3748. 
(2005b) 'The empire of political thought: civilization, savagery and perceptions of Indigenous government', History of the Human Sciences, 18, 2, pp.1-22.

(2008) The Empire of Political Thought: Indigenous Australians and the Language of Colonial Government, London, Pickering and Chatto Publishers Ltd.

Bruyneel, Kevin (2007) The Third Space of Sovereignty: The Postcolonial Politics of U.S-Indigenous Relations, Minneapolis, University of Minnesota Press.

Butler, W.F. (1917) Confiscation in Irish History, Dublin, The Talbot Press.

Butt, EA (1964) 'Romantic History of the Waikato District', The Journal of the Auckland Historical Society, 4, pp.2-5.

Butterworth, G.V (1972) 'A Rural Maori Renaissance: Maori Society and Politics 19201951', Journal of the Polynesian Society, 81, 2, pp.160-95.

Byrnes, Giselle (2003) 'Past the Last Post? Time, Causation and Treaty Claims History', Law Text Culture, 7, pp.251-76.

Campbell, SKL (1998) 'National Overview on Land Consolidation Schemes 19091931', Wellington, Crown Forestry Rental Trust.

Castellano, M.B (2004) 'Ethics of Aboriginal Research', Journal of Aboriginal Health, January, pp.98-114.

Chamerovzow, L.A (1848) The New Zealand Question and the Rights of Aborigines, London, T.C Newby.

Chilisa, Bagele (2012) Indigenous Research Methodologies, Los Angeles, Sage Publications Ltd.

Cook, Scott B (1996) Colonial Encounters in the Age of High Imperialism, New Brunswick, Harper Collins College Publishers. 
Corntassel, Jeff (2003) 'Who is Indigenous? 'Peoplehood' and Ethnonationalist Approaches to Rearticulating Indigenous Identity', Nationalism and Ethnic Politics, 9, 1, pp. $75-100$.

(2003a) 'An Activist Posing as an Academic?', American Indian Quarterly, 27,1/2, pp.160-71.

Cowan, James (1955) The New Zealand Wars: A History of the Māori Campaings and the Pioneering Period: Volume 1: 1845-1864, Wellington, R.E. Owen.

Cram, Fiona (2001) 'Rangahau Maori: Tona tika, tona pono - The validity and integrity of Maori research', in M Tolich, ed., Research Ethics in Aotearoa New Zealand: concepts, practices, critique, Auckland, Longman, pp.35-52.

Davenport, T.R.H (1985) 'Some reflections on the history of land tenure in South Africa, seen in the light of attempts by the state to impose political and economic control', Acta Juridica, pp.53-76.

Davis, Charles Oliver B (1855) Maori Momentos...collections of laments, \&c., Auckland, Williamson and Wilson.

De Vattel, Emer and Chitty, Joseph (1849) The law of nations: or, Principles of the law of nature, applied to the conduct and affairs of nations and sovereigns, London, T. \& JW Johnson.

Dean, Mitchell (1999) Governmentality: Power and Rule in Modern Society, London, Sage Publications.

Duffy, Aoife (2008) 'Indigenous Peoples' Land Rights: Developing a Sui Generis Approach to Ownership and Restitution', International Journal on Minority and Group Rights, 15, pp.505-38. 
Dunbar, Christopher (2008) 'Critical Race Theory and Indigenous Methodologies', in

Norman K. Denzin et al., eds., Handbook of Critical Indigenous Methodologies, Los Angeles, Sage Publications, Inc., pp.85-147.

Durie, E T (1996) 'Will the Settlers Settle? Cultural Conciliation and Law', Otago Law Review, 8,4, pp.449-66.

(1998) 'Ethics and Values', Te Oru Rangahau Maori Research and Development Conference, Massey University, pp.1-11.

(1998) 'Ethics and Values in Maori Research', He Kupenga Korero: A Journal of Maori Studies, 4,1, pp.19-25.

(2004) 'Maori Research, Ethics and Law', Tikanga Rangahau Matauranga Māori Tuku Iho: Traditional Knowledge and Reseach Ethics Conference, Auckland, Nga Pae o te Maramatanga, pp.47-56.

(2005) 'The Rule of Law, Biculturalism and Multiculturalism', Waikato Law Review: Taumauri, 13, pp.41-45.

Durie, Mason (1998) Te Mana, Te Kawanatanga: The Politics of Maori SelfDetermination, Auckland, Oxford University Press.

(1998) 'Strategic Direction for Maori Research', He Kupenga Korero: A Journal of Maori Studies, 4, 1, pp.77-84.

(2002) 'Universal Provision, Indigeneity and the Treaty of Waitangi', Victoria University of Wellington Law Review, 33, pp.167-77.

(2003) Nga Kahui Pou: Launching Maori Futures, Wellington, Huia Publications. 
(2005) 'Tino Rangatiratanga', in Michael Belgrave, Merata Kawharu, and David Williams, eds., Waitangi Revisited: Perspectives on the Treaty of Waitangi, Melbourne, Oxford University Press, pp.3-19.

(2005) 'Indigenous Knowledge Within a Global Knowledge System', Higher Education Policy, 18, pp.301-12.

Fedorowich, Kent (2007) 'The British Empire on the Move, 1760-1914', in Sarah Stockwell, ed., The British Empire: Themes and Perspectives, Blackwell Publishing, pp.34-93.

Fieldhouse, D K (1973) Economics and Empire: 1830-1914, London, Cox \& Wyman Ltd.

Ford, Lisa (2008) 'Indigenous Policy and its Historical Occlusions: The Northern America and global contexts of Australian Settlement', Australian Indigenous Law Review, 12, pp.69-80.

Galvin, W (1978) 'Maori Land Development with Particular Reference to Land Development at Pouto, Northland', Auckland University Law Review, 3, pp.291-305.

Gaudry, A.J (2011) 'Insurgent Research', Wicazo Sa Review, 26, 1, pp.113-36.

George Boutwell (1864) Confiscation of Rebel Property, Washington, McGill \& Witherow.

Gilling, B (1994) 'Engine of Destruction? An Introduction to the History of the Maori Land Court', Victoria University of Wellington Law Review, 24, pp.115-40.

(2001) 'Raupatu: The Punitive Confiscation of Maori Land in the 1860s', in A.R Buck, J McLaren, and N E Wright (eds.), Land and Freedom: Law, property rights and the British diaspora, Aldershot, Ashgate Publishing Ltd, pp.117-34. 
(2009) 'Raupatu: the Punitive Confiscation of Maori Land in the 1860s', in Richard Boast and Richard Hill, ed., Raupatu: The Confiscation of Maori Land, Wellington, Victoria University Press, pp.13-30.

Guelke, L (1988) 'The anatomy of a colonial settler population: Cape Colony 16571750', The International Journal of African Historical Studies, 21, 3, pp.453-473.

Hargreaves, R.P (1959) 'The Maori agriculture of the Auckland Province in the midnineteenth-century', Journal of the Polynesian Society, 68, 2, pp.61-79.

(1960) 'Maori agriculture after the wars (1971-1886)', Journal of the Polynesian Society, 69, 4, pp.354-67.

(1961) 'Maori flour mills of the Auckland Province', Journal of the Polynesian Society, 70, 2, pp.227-32.

Harris, Aroha (1997) 'Maori Land Title Improvement since 1945: Communal ownership and economic use ', New Zealand Journal of History, 31 (1), pp.132-52.

Harris, Graham and Tipene, Percy (2006) 'Maori Land Development', in Malcolm Mulholland and contributors (ed.), State of the Maori Nation: twenty first century issues in Aotearoa, Auckland, Reed Publishing Ltd, pp.67-79.

Havemann, Paul (2000) 'Reconciliatory Justice for Indigenous Peoples in the AngloCommonwealth?', Yearbook of New Zealand Jurisprudence, 4, pp.1-19.

Hawke, G.R (1985) The Making of New Zealand, Cambridge, Cambridge University Press.

Heyd, T. (1995) 'Indigenous knowledge, emancipation and alienation', Knowledge, Technology \& Policy, 8, 1, pp.63-73. 
Hickford, Mark (2010) 'Vague Native Rights to Land': British Imperial Policy on Native Title and Custom in New Zealand, 1837-53', The Journal of Imperial and Commonwealth History, 38, 2, pp.175-206.

Hill, Richard (2004) State Authority, Indigenous Autonomy: Crown-Maori Relations in New Zealand/Aotearoa 1900-1950, Wellington, Victoria University Press.

(2009) Maori and the State: Crown-Maori Relations in New Zealand/Aotearoa, 1950-2000, Wellington, Victoria University Press.

Hokowhitu, Brendon et al. (2010), Indigenous Identity and Resistance: Researching the Diversity of Knowledge, eds., Dunedin, Otago University Press.

Holmes, J R (1967) 'Fragmentation of Maori Land', Auckland University Law Review, 1, pp.1-19.

Hook, S (1995) National Interest and Foreign Aid, London, Lynne Rienner Publishers.

Hooper, Keith and Kate Kearins (2008) 'The walrus, carpenter and oysters: Liberal reform, hypocrisy and expertocracy in Maori land loss in New Zealand 1885-1911', Critical Perspectives on Accounting, 19, 8, pp.1239-62.

Huff, Andrew (2005) 'Indigenous Land Rights and the New Self-Determination', Colorado Journal of International Environmental Law and Policy, 16, 2, pp.295-332.

Hyam, Ronald (2002) Britains Imperial Century, 1815-1915: A study of Empire and Expansion, Hampshire, Palgrave MacMillan.

Irwin, Kathie (1994) 'Maori Research Methods and Practices', Sites, 28, Autumn, pp.2543.

Jackson, Moana (1992) 'The Treaty and the Word', in G Oddie and R W Perrett (eds.), Justice, Ethics and New Zealand Society, Auckland, Oxford University Press, pp.1-10. 
(1998) 'Research and the Colonisation of Maori Knowledge', He Kupenga Korero: A Journal of Maori Studies, 4, 1, pp.69-76.

(2007) 'Its Quite Simple Really', Yearbook of New Zealand Jurisprudence, 10, 32-40.

Jackson, Taharee Apirom (2011) 'Which interests are served by the principle of interest convergence? Whiteness, collective trauma, and the case for anti-racism', Race Ethnicity and Education, 14,4, pp.435-59.

Johnson, Robert (2003) British Imperialism, Basingstoke, Palgrave Macmillan.

Jones, Camara Phyllis (2000) 'Levels of racism: A theoretic framework and a gardener's tale', American Journal of Public Health, 90, 8, pp.1212-15.

Jones, Pei Te Hurinui (1959) King Pōtatau, Wellington, The Polynesian Society.

Kawharu, I H (1977) Maori Land Tenure: Studies of a changing institution, Oxford, Oxford University Press.

(1999) 'Foreward', in David Williams, ed.. Te Kooti Tango Whenua: The Native Land Court 1864-1909, Wellington, Huia Publishers, pp.xv-xvii.

Keefe, V et al. (1999) 'Kaupapa Maori meets Retrospective Cohort', He Kupenga Korero: A Journal of Maori Studies, 5, 1, pp.12-17.

Keenan, Danny (1999) 'Predicting the Past: Some Directions in Recent Maori Historiography', Te Pouhere Korero, 1, 1, pp.24-35.

(2009) Wars Without End: The Land Wars in Nineteenth-century New Zealand (Auckland: Penguin Books).

Keenan, Desmond (2010) Ireland 1170-1509, Society and History, Bloomington, Xlibris. 
Kelly, Brigid (2003) 'The Alienation of Land in Ireland and in Aotearoa/New Zealand under English Colonisation', Auckland University Law Review, 9, 4, pp.1353-66.

Kelly, Leslie G (1949), Tainui, Wellington, The Polynesian Society (Inc.).

King, M (1977) Te Puea: A Biography, $1^{\text {st }}$ Edn, Auckland, Hodder and Stoughton. (2003) The Penguin History of New Zealand, Auckland, Penguin Books.

Lal, Deepak (2004) In Praise of Empires: Globalisation and Order New York, Palgrave MacMillan.

Lawn, CA (1966) 'Surveyor's Big Role in N.Z History', The Journal of the Auckland Historical Society, 8, pp.16-25.

Lebovics, Herman (2006) Imperialism and the Corruption of Democracies, London, Duke University Press.

Lemke, T (2002) 'Foucault, Governmentality, and Critique', Rethinking Maxism, 14, 3, pp.49-64.

Lewthwaite, Gordon R (1964) 'Wisconsin and the Waikato: A Comparison of Dairy Farming in the United States and New Zealand', Annals of the Association of American Geographers, 54, 1, pp.59-87.

Lian, K.F. (1992) 'Tribe, class and colonisation: the political organisation of Maori society', Journal of the Polynesian Society, 101, 4, pp.387-408.

Locke, J. (1690) Second Treatise of Civil Government, as downloaded on 4 October 2013 at: http://oll.libertyfund.org/index.php?option $=$ com staticxt\&staticfile=show.php $\% 3$ Ftitle= $\underline{222 \& \text { layout }=\text { html\#chapter_16269 }}$ 
Loeber, R Harman et al. (2001) 'Prelude to Confiscation: A Survey of Catholic Estates in Leinster in 1690', The Journal of the Royal Society of Antiquaries of Ireland, 131, pp.61-139.

Loomba, Ania (1998) Colonialism/Postcolonialism, London, Routledge.

Lytton, Bluwer (1883) in Hanson Turton, An Epitome of Official Documents Relative to Native Affairs and Land Purchases in the North Island of New Zealand, George Didsbury, Wellington, 1883.

Maaka, R and Augie Fleras (2005) The Politics of Indigeneity: Challenging the State in Canada and Aotearoa New Zealand, Dunedin, Otago University Press.

MacDonald, Lindsay (2006) 'Globalisation, neo-liberalism and the struggle for indigenous citizenship', Australian Journal of Political Studies, 41, 2, pp.209-23.

MacKay, Alexander (1872) A Compendium of Official Documents relative to the Native Affairs in the South Island, Volume 1, Nelson, Luckie and Collins.

MacKay, James (1887) Our Dealings with Maori Lands; Comments on European Dealings for the Purchase and Lease of Native Lands and the Legislation thereon, Auckland, Kidd \& Wildman.

MacLachlan, R.J (1968) Land Administration in New Zealand: An Evolutionary account of the influence of land policy on New Zealand's social, economic and physical development, Wellington, Government Printer.

MacQueen, Norrie (2007) Colonialism, Harlow, Pearson Longman.

Mahuika, Nepia (2009) 'Revitalising Te Ika-a-Maui: Maori Migration and the Nation', New Zealand Journal of History, 43, 2, pp.133-49.

(2011) 'Closing the Gaps: From Postcolonialism to Kaupapa Maori and Beyond', New Zealand Journal of History, 45, 1, pp.15-32. 
Mahuta, Dean (2008) 'Raupatu: A Waikato Perspective', Te Kaharoa, 1, pp.174-82.

(2011) 'Honouring the voices of the Ancestors - A Personal View of the Effect of Maori Language Immersion Education in Aotearoa-New Zealand', Te Kaharoa, 4, pp.180-194.

Mahuta, Robert (1995) 'Tainui, Kingitanga and Raupatu', in Margaret Wilson and Anna Yeatman ed., Justice and Identity: Antipodean Practices, Wellington, Bridget Williams Books Ltd, pp.18-32.

(1995) 'Tainui: A Case Study of Direct Negotiation', Victoria University of Wellington Law Review, 25, pp.157-177.

McCan, David (2001) Whatiwhatihoe: The Waikato Raupatu Claim, Wellington, Huia Publishers.

McHugh, P.G (1979) 'The alienation of Maori Land under Part XXIII and Section 438 of the Maori Affairs Act 1953', Victoria University of Wellington Law Review, 10, pp.153-78.

(1982) 'The Economic Development of Native Land: New Zealand and Canadian Law Compared', Sasketchewan Law Review 47, pp.119-52.

(1986) 'Aboriginal servitudes and the Land Transfer Act 1952', Victoria University of Wellington Law Review, 16, pp.313-35.

(1988) 'The Legal Basis for Maori Claims against the Crown', Victoria University of Wellington Law Review, 18, pp.1-20.

(1997) 'Crown-Tribe Relations: Contractualism and Coexistence in an Intercultural Context', in Glyn Davis et al, eds., The New Contractualism, Melbourne, MacMillan Education Australia, pp.198-216. 
Mead, H.M (2012) 'Understanding Matauranga Maori', in Nga Kaituhono ed., Conversations on Matauranga Māori, Wellington, New Zealand Qualifications Authourity, pp.9-14.

Merryman, J.H. (1989) 'The Public Interest in Cultural Property', California Law Review, 77 2, pp.339-64.

Merwe, Derek Van Der (1989) 'Land tenure in South Africa: a brief history and some reform proposals', Journal for South African Law, 4, pp.663-92.

Mikaere, A. (2005) 'The Treaty of Waitangi and recognition of Tikanga Maori', in Michael Belgrave et al, eds., Waitangi Revisited: Perspectives on the Treaty of Waitangi, Melbourne: Oxford University Press, pp.330-48.

Miranda, Lillian Aponte (2008) 'Uploading the Local: Assessing the Contemporary Relationship between Indigenous Peoples' Land Tenure Systems and International Human Rights Law regarding the Allocation of Traditional Lands and Resources in Latin America', Oregan Review of International Review, 10, 2008, pp.419-452

Mulholland, Malcolm (2006) State of the Maori Nation: twenty first century issues in Aotearoa,Auckland, Reed Publishers Ltd.

Murphy, Michael A (2008) 'Representing Indigenous Self Determination', University of Toronto Law Journal, 58, pp.185-216.

Mutu, Margaret (1998) 'Barriers to Research: The Constraints of Imposed Framework', He Kupenga Korero: A Journal of Maori Studies, 4, 1, pp.9-18.

Neizen, R (2009) The Rediscovered Self: Indigenous Identity and Cultural Justice, London, McGill-Queens University Press.

Nightingale, T (1992) White Collars and Gumboots: A History of the Ministry of Agriculture and Fisheries 1892-1992, Palmerston North, Dunmore Press Ltd. 
Norris, HCM (1973) 'Glimpse of Waikato History 1820-1870', Journal of the AucklandWaikato Historical Societies, 22, pp.20-24.

O'Malley, Vincent (1998) Agents of Autonomy: Maori Committees in the NineteenthCentury, Wellington, Huia Publishers.

(2009) 'Reinventing Tribal Mechanisms of Governance: The Emergence of Maori Runanga and Komiti in New Zealand before 1900', Ethnohistory, 56,1, pp.69-89.

O'Regan, T (2001) 'Old Myths and New Politics: Some Contemporary Uses of Traditional History', in Judith Binney, ed., The Shaping of History: Essays from the New Zealand Journal of History, Wellington, Bridget Williams Books, pp.15-37.

Oddie, G and R W Perrett, (1992) Justice, Ethics and New Zealand Society, eds., Auckland, Oxford University Press.

Orange, C (1987) The Treaty of Waitangi, Wellington, Allen \& Unwin.

Palmer, Kenneth (1981-82) 'Acquisition of Maori Land for Public Works', Town Planning Quarterly, 65, pp.35-43.

Pearson, D (1990) A Dream Deferred, Wellington, Allen \& Urwin.

Pere, J (1991) 'Hitori Maori', in Colin Davis and Peter Lineham, eds., The Future of the Past: Themes in New Zealand History, Palmerston North, Massey University, pp.29-48.

Petrie, Hazel (2006) Chiefs of Industry: Maori Tribal Enterprise in Early Colonial New Zealand, Auckland, Auckland University Press.

Pocock, J.G.A (2000) 'Waitangi as Mystery of State: Consequences of the Ascription of Federative Capacity to the Maori', in Duncan Ivison et al., eds., Political Theory and the Rights of Indigenous Peoples, Cambridge, Cambridge University Press, pp.25-35. 
Rae, DA (1974) 'Birth of the Meat Export Trade', Journal of the Auckland-Waikato Historical Societies, 24, pp.8-13.

Reilly, Michael (2011) 'Maori Studies, Past and Present', The Contemporary Pacific, 23, 2, pp.340-69.

Renwick, William (1991) Sovereignty and Indigenous Rights, ed., Wellington Victoria University Press.

Roa, Tom (2005) 'Tikanga Tainui: Tikanga Whare Wananga', He Puna Korero: Journal of Maori and Pacific Development, 6, 2, pp.3-8.

Rosenberg, G (1966) 'Maori Land Tenure and Land use: A Planner's point on view ', The Journal of the Polynesian Society, 75, 2, pp.210-22.

Royal Institute of International Affairs (1938) The British Empire: A Report on its structure and problems, London, Oxford University Press.

Said, Edward (1979) Orientalism, New York, Vintage Books.

(1990) 'Yeats and Decolonisation', in Seamus Deane, ed., Nationalism, Colonialism and Literature, Minneapolis, University of Minnesota Press, pp.69-95.

(1993) Culture and Imperialism, New York, Alfred A. Knopf, Inc.

Salmon, J.T (1980) The Native Trees of New Zealand, Auckland, Heinemann Reed.

Seuffert, Nan (1998) 'Colonising concepts of the Good Citizen, Law's Deceptions and the Treaty of Waitangi', Law Text Culture, 4, 2, pp.69-104.

Shand, Peter (1998) 'Fixing Settlement: An Analysis of Government Policy for Settling Tiriti Grievances', 8, 3, pp.739-68. 
Sherson, C (1981) Kahikatea, Cabbage Trees \& Koromiko, Waiuku, W.J. Deed Printing Limited.

Short, Damien (2003) 'Reconciliation, Assimilation and the Indigenous Peoples of Australia', International Political Science Review, 24, 4, pp.491-513.

Sinclair, Keith (1957) The origins of the Maori wars, Wellington, New Zealand University Press.

Smith, Anthony (2002) 'When is a Nation', Geopolitics, 7, 2, pp.5-32.

Smith, Linda (1999) Decolonizing Methodologies: Research and Indigenous Peoples, Dunedin, University of Otago Press.

(2010) 'Colonizing Knowledges', in M Bruchae et al, eds., Indigenous Archaeologies: A Reader on Decolonisation, Left Coast Press.

Smith, N (1942) Native Custom and Law Affecting Native Land, Wellington, The Maori Purposes Fund Board.

Southalan, John (2009) 'Australian Indigenous - Resource developments: Martu People v Reward Minerals', Energy and Natural Resources Law, 27, 4, pp.671-85.

St John, J (1873) A Pakeha Rambles through Māori Lands, Wellington, Robert Burnett.

Stockwell, Sarah (2007) The British Empire: Themes and Perspectives, ed., Blackwell, Blackwell Publishing.

Takarei, M and Jo Thapa (2008) Nga Tongi o Tawhiao, Te Pou Taki Korero.

Te Aho, L (2006) 'Contemporary issues in Maori law and society: Mana motuhake, mana whenua', Waikato Law Review, 14, pp.102-19. 
(2007) 'Creating Our Own Prosperity - Human Rights from a Tainui Perspective', Yearbook of New Zealand Jurisprudence, 10, pp.43-52.

(2008) 'Contemporary issues in Maori law and society the tangled web of Treaty Settlements emissions trading, Central North Island forests, and the Waikato river', Waikato Law Review, 16, pp.229-50.

Turongo House (2000) Tawhiao: King or Prophet, Hamilton, Waikato Raupatu Lands Trust.

Turton, H Hanson (1883) An Epitome of Official documents Relatives to Native Affairs and Land Purchases in the North Island of New Zealand, Wellington, George Didsbury.

Van Meijl, Toon (2003) 'Conflicts of redistribution in contemporary Maori Society: Leadership and Tainui Settlement, Journal of the Polynesian Society, 112, 3, pp.260279.

Vance, L.J (1916) 'The Road to Confiscation', The Yale Law Journal, 25, 4, pp.285-305.

Wakefield, Felix (1849) Colonial Surveying with a view to the Disposal of Waste Land: In a report to the New Zealand Company, London, J W Parker.

Waitangi Tribunal (1985) 'Report of the Waitangi Tribunal on the Manukau Claim (Wai-8)', in Department of Justice ed., Wellington, Waitangi Tribunal.

(1987) 'Report of the Waitangi Tribunal on the Orakei Claim (Wai9)', Wellington, Brooker \& Friend Ltd.

(1988) 'Report of the Waitangi Tribunal on the Muriwhenua Fishing Claim', Wellington, Waitangi Tribunal. (1993) 'Report of the Waitangi Tribunal on the Tuhuru Claim (Wai $322)^{\prime}$. 
(2004) 'Te Raupatu o Tauranga Moana: Report on the Tauranga Confiscation Claims', Wellington, Waitangi Tribunal.

(2006) 'The Hauraki Report', Wellington, Legislation Direct.

Walker, Ranginui (2004a) Ka Whawhai Tonu Matou: Struggle without End, Auckland, Penguin Books.

Walling, J, et al. (2009) 'Tallying tribes: Waikato-Tainui in the census and Iwi register', Social Policy Journal of New Zealand, 36, pp.2-15.

Ward, A (1999) An Unsettled History: Treaty Claims in New Zealand Today, Wellington, Bridget Williams Books.

(2009) 'A 'Savage War of Peace?' Motives for Government Policies Towards the Kingitanga, 1857-1863', in Richard Boast and Richard Hill, eds., Raupatu: The Confiscation of Maori Land, Wellington, Victoria University Press, pp.67-109.

Webber, Jeremy (1999) 'Native Title as Self Government', University of New South Wales Law Journal, 22, 2, pp.600-03.

Webster, S (1998) 'Maori Hapu as a Whole Way of Struggle: 1840s-50s before the Land Wars', Oceania, 69, 1, pp.4-35.

Wharepouri, Mina (1992) 'The Phenomenon of Agreement: A Maori View', Auckland University Law Review, 7, pp.603-17.

Wheeler, C E (1921a) Dairy Farming in New Zealand, Wellington, Harry H Tombs Limited.

(1921b) New Zealand: The Country, its People and Resources, Auckland, Brett Printing and Publishing Company Ltd. 
Williams, David (1999) Te Kooti Tango Whenua: The Native Land Court 1864-1909, Wellington, Huia Publishers.

Williams, Joe (2008) 'Confessions of a Native Judge: Reflections on the role of transitional justice in the transformation of indigeneity', Land, Rights, Laws: Issues of Native Title, Volume 3, Issue Paper No. 14.

(2010) 'Confessions of a Native Judge: Reflections on the role of transitional justice in the transformation of indigeneity', in L Strelein, ed., Dialogue about Land Justice: Papers from the National Native Title Conference, Aboriginal Studies Press, pp.19-32.

Williams, Jim (2010) 'Towards a Model for Indigenous Research', in Kermoal Hokowhitu, Andersen, Petersen, Reilly, Altamirano-Jimenez, Rewi eds., Indigenous Identity and Resistance: Researching the Diversity of Knowledge, Dunedin, Oxford University Press, pp.107-123.

Williams, Robert A (2012) Savage Anxieties: The Invention of Western Civilisation, New York, Palgrave MacMillan.

Wood, Vaughan et al. (2008) 'Pastoralism and politics: reinterpreting contests for territory in Auckland Province, New Zealand, 1853-1864', Journal of Historical Geography, 34, 2, pp.220-41.

Young, Robert (2001) Postcolonisation, Oxford, Blackwell Publishers.

\section{Websites}

www.Kiingitana.com

www.Māoridictionary.co.nz

www.netlist.co.nz

http://oll.libertyfund.org

$\underline{\text { www.eastonbh.ac.nz }}$

http://en.wikipedia.org 
http://www.teara.govt.nz

http://www.linz.govt.nz

http://www3.stats.govt.nz

http://www.nzherald.co.nz

http://www.oxforddictionaries.com

\section{Newspaper articles*}

Daily Southern Cross, 'Whangamarino', Volume XX, Issue 2124, 11 May 1864.

Daily Southern Cross, Volume XXIV, Issue 3433, 17 July 1868, p.2

Daily Southern Cross, 'Preemptory Sale of Country Land and Surburban Lots', Volume XXIV, Issue 3440, 25 July 1868.

Daily Southern Cross, 'Government Land Sale', 18 January 1870.

Freedom, 'M.P. Makes Case for Development of Idle Maori Lands', 20 July 1949.

New Zealand Herald, 'Waste Lands Office: Whangamarino Creek, North Side', Volume III, Issue 832, 12 July 1866.

New Zealand Herald, 'Tainui still in division over \$70m', 25 February 2013.

Waikato Times, 'Rangiriri Outlying district', 6 September 1883.

Waikato Times, 'Land Sale', 29 December 1883.

*Denotes a sample of the number of references utilized in this category that are directly relevant to Waikato or the Parish of Whangamarino.

** Relates to a small sample of the 242 Archive New Zealand files accessed during the course of this research. 